SÉRGIO CIRELLI ANGULO

\title{
VARIABILIDADE DE AGREGADOS GRAÚDOS DE RESÍDUOS DE CONSTRUÇÃO E DEMOLIÇÃO RECICLADOS
}

\author{
Dissertação apresentada à Escola \\ Politécnica da Universidade de São \\ Paulo para obtenção do título de \\ Mestre em Engenharia
}


SÉRGIO CIRELLI ANGULO

\section{VARIABILIDADE DE AGREGADOS GRAÚDOS DE RESÍDUOS DE CONSTRUÇÃO E DEMOLIÇÃO RECICLADOS}

Dissertação apresentada à Escola Politécnica da Universidade de São Paulo para obtenção do título de Mestre em Engenharia

Área de Concentração:

Engenharia de Construção Civil e Urbana

Orientador:

Vanderley Moacyr John 
Angulo, Sérgio Cirelli

Variabilidade de agregados graúdos de resíduos de construção e demolição reciclados. São Paulo, 2000.

$155 \mathrm{p}$.

Dissertação (Mestrado) - Escola Politécnica da Universidade de São Paulo. Departamento de Engenharia de Construção Civil.

1. Resíduo 2. Reciclagem 3. Agregados 4. Entulho 5. Variabilidade 6. Análise de imagem I. Universidade de São Paulo. Escola Politécnica. Departamento de Engenharia de Construção Civil II. $\mathrm{t}$ 
A Deus,

A minha família

E aos pioneiros na defesa do meio ambiente. 


\section{AGRADECIMENTOS}

Neste período, na Universidade de São Paulo, por quase dois anos de minha vida, muito evoluí intelectualmente, seja pela diversidade e riqueza de conhecimentos aqui desenvolvidos, seja pelos professores e qualificados profissionais que aceitaram me orientar. Em todos os sentidos, somente marcas positivas me foram deixadas por essa grande universidade pública, que teima em resistir, apesar das políticas atuais. Mas, com certeza, essa (que eu conheci) tem muito ainda a ensinar e a fazer pela sociedade.

Devo agradecer ao meu primeiro mestre, Prof. Gilson Morales, da Universidade de Londrina, que me iniciou na pesquisa, ensinando-me a desenvolver projetos, o que, no Mestrado, ajudou-me muito. Muito devo ao Prof. Dr. Vanderley Moacyr John, que acreditou no meu trabalho, até então uma pesquisa de Iniciação Científica desenvolvida na Universidade de Londrina, e aceitou me orientar dentro da linha de pesquisa iniciada. Como orientador e como professor da disciplina de Resíduos, apresentou-me o conceito de desenvolvimento sustentável e incentivou-me na pesquisa da reciclagem de resíduos voltados para a Construção Civil. Participou da elaboração deste projeto, ensinando-me a pensar, dirigindo minhas atividades com objetividade. Acrescentou muitas idéias a este trabalho, envolvendo-se e incentivando-me. Sua participação, no final deste trabalho, foi indispensável para as conclusões aqui apresentadas.

Aos Professores das disciplinas que cursei que me mostraram outros estágios do conhecimento, alargando meu universo de pesquisa. Sinceros agradecimentos aos professores Alex Abiko, Paulo Helene, Vahan Agopyan, Antônio Figueiredo, Ubiraci Espinelli Souza e Maria Alba Cincotto, professora por quem tenho profunda admiração.

À Coordenadoria de Aperfeiçoamento de Pessoal de Ensino Superior - CAPES - e ao Departamento de Engenharia de Construção Civil da EPUSP que viabilizaram a realização e custearam a infra-estrutura desta dissertação.

Ao Dr. Tarcísio de Paula Pinto, pioneiro no estudo de resíduos de construção e demolição, pelas contribuições a este estudo, em reuniões ou durante meu Exame de Qualificação do qual participou.

Ao Prof. Dr. Eduardo Toledo Santos que contribuiu no desenvolvimento da metodologia que emprega a técnica de análise de imagem, dando sugestões e indicando bibliografias. 
Ao Reginaldo Mariano da Silva, Dorval D. Aguiar, Adilson Inácio dos Santos, João Carlos Soares, Mário Souza Takeashi e Renata Monte pelo auxílio na etapa experimental.

Ao Rogério de Toledo e Patrícia R. de Freitas, pelas soluções dos problemas de informática que sugiram durante este trabalho.

Ao NIPP (Núcleo de Inovação em Políticas Públicas), da cidade de Santo André, pelo fornecimento dos agregados e infra-estrutura para a coleta de amostras. Especiais agradecimentos ao arquiteto Gilson Lameira, engenheiro Marcos Tamai e funcionários da britagem.

Ao Msc. Salomon Mony Levy pelo fornecimento de agregados reciclados de laboratório.

Ao Paulo Heitzmann, Fátima Regina G. Sanches Domigues e Engrácia Maria Bartuciotti pela ajuda na solução de problemas relacionados ao departamento.

À Maria de Fátima da Silva Paiva, Leonor Madalena Machado Rosa Andrade e ao Fernando Ricardo de Brito pela ajuda na pesquisa bibliográfica.

Aos alunos de Iniciação Científica que participaram desta pesquisa, Fabiana Negrini Suarez (obrigado pela dedicação intelectual e física nas horas consumidas em uma central de moagem), Fabiana Cleto e Maurício Dainezi (para ambos agradecimentos pela disposição e persistência nas caracterizações de Laboratório, especialmente pelos incômodos ensaios de granulometria).

Aos meus verdadeiros amigos que torceram pelo sucesso deste trabalho, dentro e fora do meu ambiente de trabalho.

Aos meus pais, Ivan de Lucena Angulo e Regina Aparecida Cirelli Angulo, que não pouparam recursos físicos e emocionais para tornar realidade o meu sonho. Aos meus tios, Luis Carlos Cirelli e Eliete Hercolin Cirelli, que me acolheram carinhosamente em São Paulo como um membro de sua família.

Aos meus companheiros de Sala Asteróide, com os quais dividi experiências e suor! Aos companheiros da Sala GRS e Reciclagem.

À Veridiana Maria Armond Vasconcelos, Dra. Linda Ho e especialmente Dra. Neide Sato (pelas reuniões, disposição e empréstimo de livros), pela ajuda nos conhecimentos de estatística.

Ao Prof. Henrique Kahn, pelos esclarecimentos de conceitos de análise de imagem. 
À minha mãe, mais uma vez, pelas revisões de Língua Portuguesa.

Aos amigos Leonardo Miranda e Rubiane Paz do Nascimento Antunes, pelo companheirismo e inúmeras revisões finais. 


\section{SUMÂRIO}

\section{LISTA DE FIGURAS}

\section{LISTA DE TABELAS}

RESUMO

ABSTRACT

INTRODUÇÃO.

1 RESÍDUOS DE CONSTRUÇÃO E DEMOLIÇÃO ...........................................................

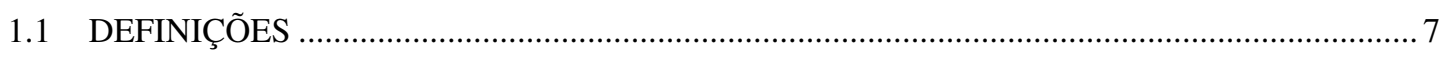

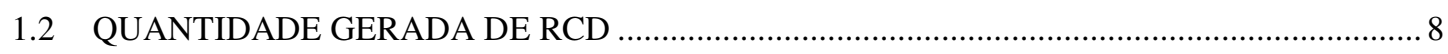

1.3 COMPOSIÇÃO, VARIABILIDADE E ORIGEM DOS RCD …………………….................. 10

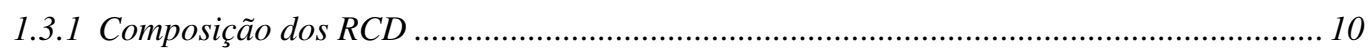

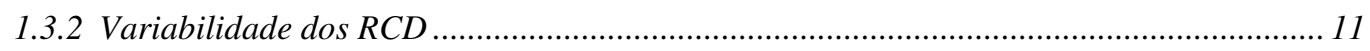

1.3.3 Origem dos resíduos de novas construções..................................................................... 12

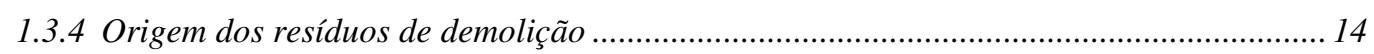

1.4 CONSEQÜÊNCIAS AMBIENTAIS DA DEPOSIÇÃO DE RCD........................................... 15

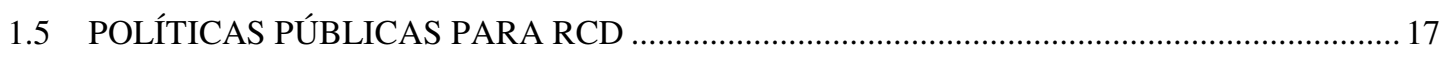

2 RECICLAGEM DOS RCD COMO AGREGADOS ..................................................................22

2.1 PROCESSO DE PRODUÇÃO DOS AGREGADOS DE RCD RECICLADOS ............................ 22

2.2 PRESENÇA DE CONTAMINAÇÕES E MATERIAIS INDESEJÁVEIS …………....................28

2.3 UTILIZAÇÃO DOS AGREGADOS DE RCD RECICLADOS ………...................................

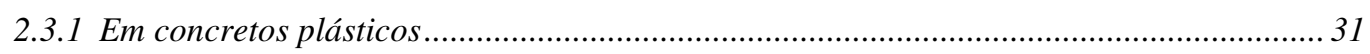

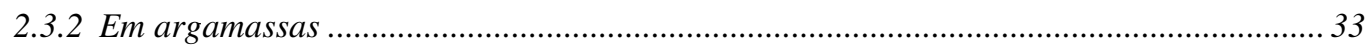

2.3.3 Considerações sobre o estado fresco de concretos e argamassas ...................................... 34

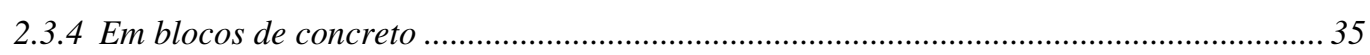

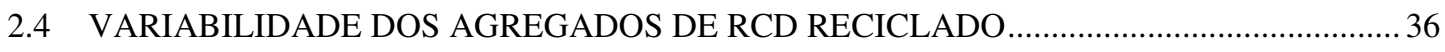

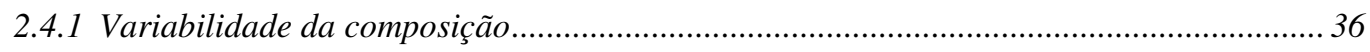

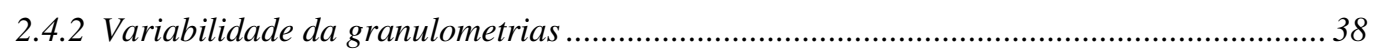

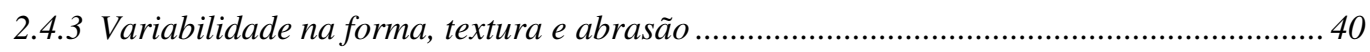

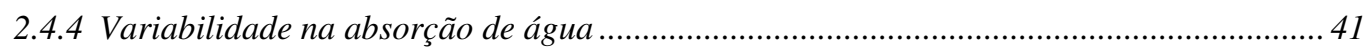

2.4.5 Variabilidade nas propriedades de argamassas .................................................................. 43

2.4.6 Variabilidade nas propriedades de concretos plásticos....................................................... 45

2.5 NORMALIZAÇÃO DE AGREGADOS GRAÚDOS DE RCD RECICLADOS PARA

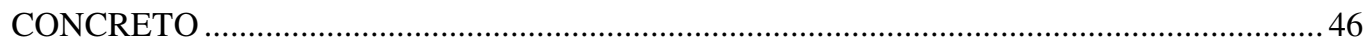

3 MÉTODOS DE ESTUDO DE COMPOSIÇÃO DE AGREGADOS DE RCD RECICLADOS.. 


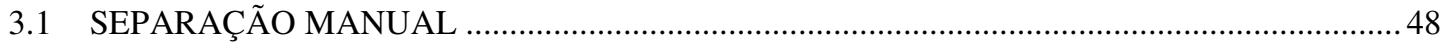

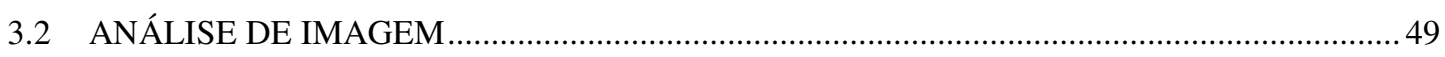

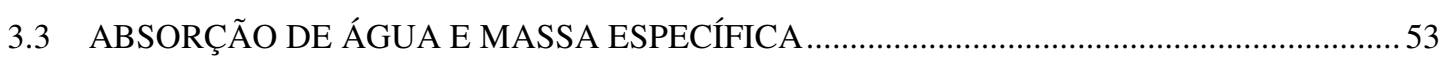

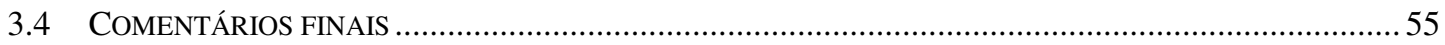

4 PROGRAMA EXPERIMENTAL, MATERIAIS E MÉTODOS ............................................57

4.1 RESUMOS DOS PROCEDIMENTOS ADOTADOS ……….................................................. 57

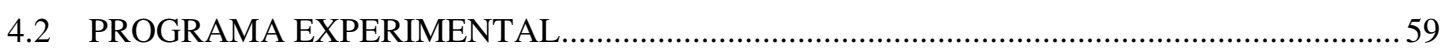

4.2.1 Estudo da composição por análise de imagem...............................................................59

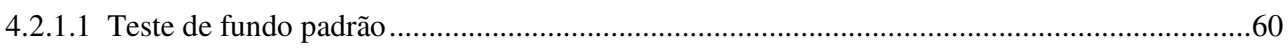

4.2.1.2 Precisão da determinação das dimensões por análise de imagem. .........................................60

4.2.1.3 Estudo da capacidade de separação das fases pelo programa de análise de imagem...............61

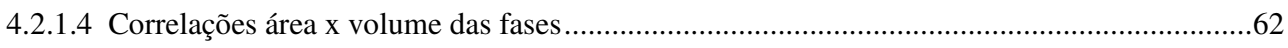

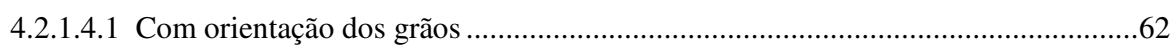

4.2.1.4.2 Sem orientação dos grãos .............................................................................63

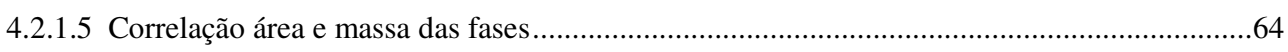

4.2.2 Uso de absorção de água e massa específica para a separação das fases concreto e

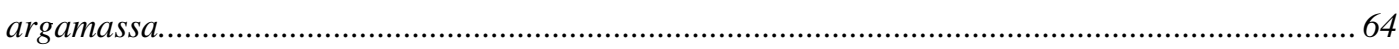

4.2.3 Avaliação da variabilidade dos agregados graúdos de RCD reciclados.......................... 66

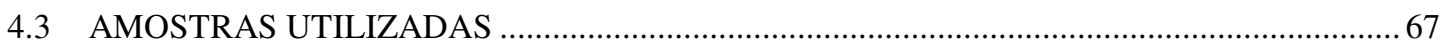

4.3.1 Amostras de agregados graúdos de RCD reciclados em laboratório ............................... 67

4.3.2 Amostras de agregados graúdos de RCD reciclados na Central de Moagem ................... 68

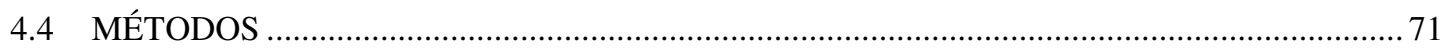

4.4.1 Estudo da composição por análise de imagem.......................................................... 71

4.4.1.1 Método de análise de imagem com orientação dos grãos...................................................... 71

4.4.1.2 Método de análise de imagem sem orientação dos grãos .......................................................72

4.4.2 Uso da absorção de água e massa específica para a separação das fases concreto e

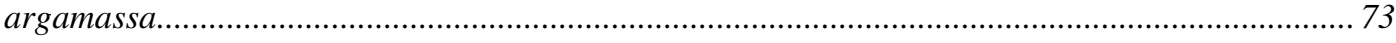

4.4.3 Método de coleta das amostras de agregados graúdos de RCD reciclados da Central de

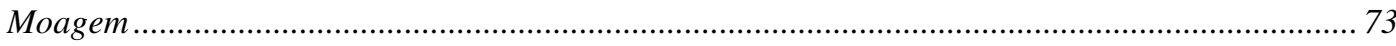

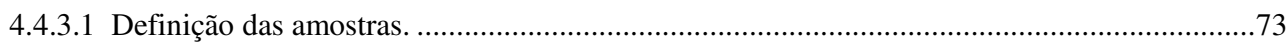

4.4.3.2 Procedimentos de coleta das amostras .............................................................................. 74

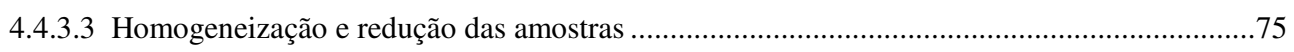

4.4.4 Avaliação da variabilidade dos agregados de $R C D$ reciclados...................................... 76

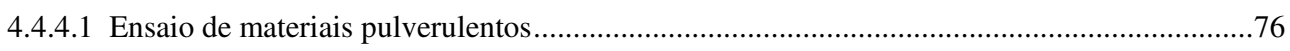

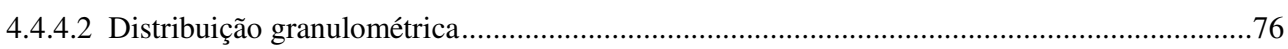

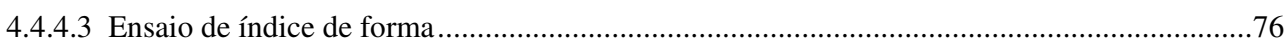

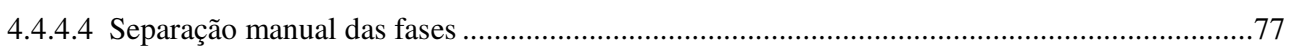

4.4.4.5 Ensaio de absorção de água e massa específica ..................................................................

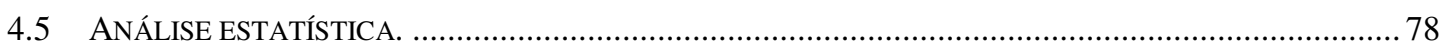

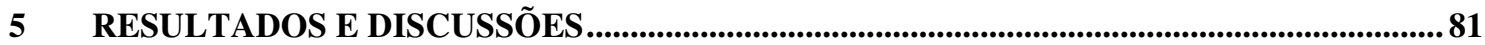


5.1 ESTUDO DA COMPOSIÇÃO POR ANÁLISE DE IMAGEM ....................................................... 81

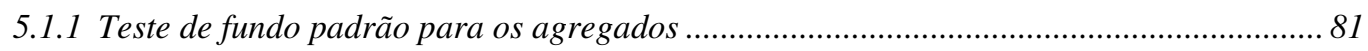

5.1.2 Precisão da determinação das dimensões por análise de imagem.......................................83

5.1.3 Estudo da capacidade de separação das fases pelo programa de análise de imagem....... 84

5.1.4 Correlações entre \%área e \%volume ..................................................................................... 89

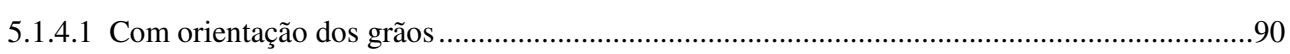

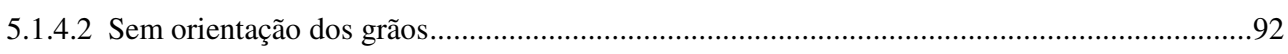

5.1.5 Correlação entre \% área e \% massa ................................................................................... 94

5.1.6 Procedimento para a separação de fases por análise de imagem......................................97

5.1.7 Aplicação do método de estudo de composição por análise de imagem............................ 99

5.2 USO DA ABSORÇÃO DE ÁGUA E MASSA ESPECÍFICA PARA A SEPARAÇÃO DAS FASES CONCRETO E

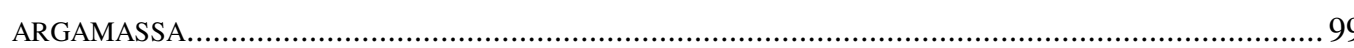

5.3 ESTUdO DA VARIABILIDADE DA PRODUÇÃO DA CENTRAL DE RECICLAGEM EM SANTO ANDRÉ.. 102

5.3.1 Proporção agregados graúdo x miúdo de RCD reciclados ............................................. 102

5.3.2 Composição dos agregados graúdos de RCD reciclados ................................................. 104

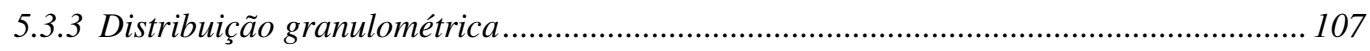

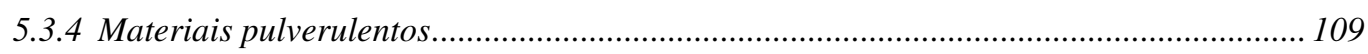

5.3.5 Massa Específica e Absorção de água dos agregados graúdos de RCD reciclados para as fases da composição. ................................................................................................ 110

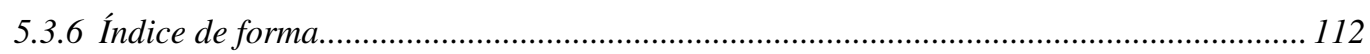

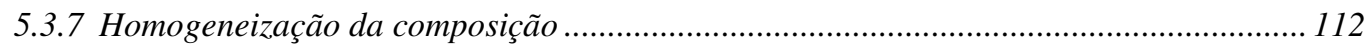

5.3.8 Correlação entre composição e propriedades ................................................................. 113

5.3.8.1 Absorção de água e massa específica.................................................................................113

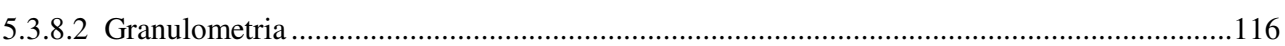

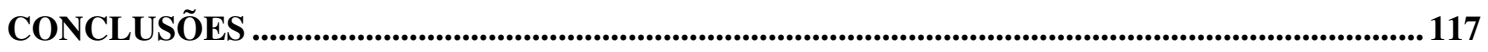

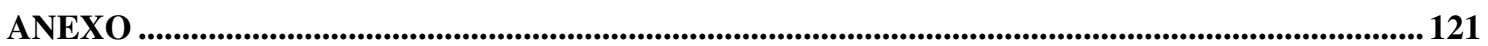

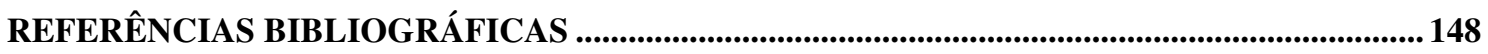




\section{LISTA DE FIGURAS}

Figura 1.1 - OBSTRUÇÃO DE RUA EM SÃO PAULO POR RCD. FONTE: VANDERLEY M. JOHN. 16

FigurA 1.2 - CiClO DE PRODUÇÃo FECHAdO PARA A CONSTRUÇÃo (CURWELL;COOPER, 1998 MODIFICADO APUD JOHN, 1999).

FIGURA 2.1 - PlantA DE RECICLAGEM DE RCD (PENG ET AL., 1997)

Figura 2.2 - FluXoGRAmA DE UMA PlANTA DE RECIClAGEM DE PRODUÇÃo DOS AGREGADOS DE RCD RECICLADOS (WILBURN; GOONAN, 1998 MODIFICADO).

Figura 2.3 - CORRELAÇÃo ENTRE QUANTIDAdE DE ARGAMASSA ADERIDA E A ABSORÇÃo DE ÁGUA AGREGADOS MIÚDOS RECICLADOS DE CONCRETO (QUEBAUD-BUYLE-BODIN, 1999)...............26

FIGURA 2.4 - LOCALIZAÇÕES DE CENTRAIS DE MOAGEM DE ENTULHO (WILBURN; GOONAN, 1998)....28

FIGURA 2.5 - PRESENÇA DE COMPONENTES ORGÂNICOS EM FUNÇÃO DAS TÉCNICAS DE RECICLAGEM

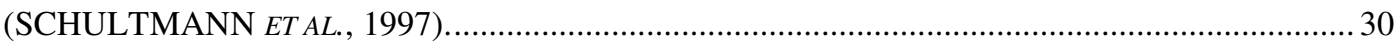

FIGURA 2.6 - CONSUMO DE CIMENTO X RESISTÊNCIA PARA CONCRETOS RECICLADOS E NATURAIS (ZORDAN ET AL., 1999). 31

FIGURA 2.7 - VARIAÇÃO DO ABATIMENTO EM RAZÃO DA ADIÇÃO DE AGREGADOS MIÚDOS RECICLADOS DE CONCRETO (QUEBAUD-BUYLE-BODIN, 1999). 34

FIGURA 2.8 - VARIABILIDADE DA COMPOSIÇÃO DOS AGREGADOS DE RCD RECICLADOS NO BRASIL

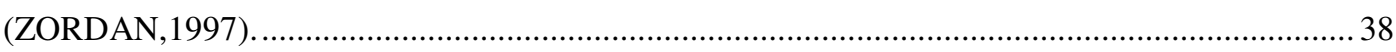

FIGURA 2.9 - CURVAS GRANULOMÉTRICAS DE AGREGADOS DE RCD RECICLADOS. 39

FIGURA 2.10 - VARIABILIDADE GRANULOMÉTRICA DE AGREGADOS DE RCD RECICLADOS (QUEBAUDBUYLE-BODIN, 1999).

FIGURA 2.11 - FAIXAS DE ABSORÇÃO DE ÁGUA DE CONCRETOS E ARGAMASSAS (ELABORADA PELO AUTOR A PARTIR DAS SEGUINTES FONTES: KIKUCHI ET AL., 1994; KASAI ET AL., 1994; YAMADA ET AL., 1994; CARNEIRO, 1999; SARAIVA, 1999).

FIGURA 2.12 - RELAÇÃO ENTRE ABSORÇÃO DE ÁGUA E QUANTIDADE DE ARGAMASSA ADERIDA AO GRÃO DE CONCRETO (HANSEN, 1992).

FIGURA 2.13 - EFEITO DA RELAÇÃO A/C E DIMENSÃO DA PARTíCULA NA \% DE PASTA ADERIDA AO GRÃO DE AGREGADOS DE CONCRETO (HANSEN, 1992).

FigurA 2.14 - RETENÇÃO DE ÁGUA DE ARGAMASSAS COM DIVERSAS COMPOSIÇÕES DE AGREGADOS (HAMASSAKI ET AL.,1997). 44

FIGURA 2.15 - RETRAÇÃO POR SECAGEM DAS ARGAMASSAS COM DIFERENTES COMPOSIÇÕES DE AGREGADOS (HAMASSAKI ET AL., 1997). .44

FIGURA 2.16 - VARIAÇÃO DO ABATIMENTO EM FUNÇÃO DA COMPOSIÇÃO, PARA TRAÇOS 1:3 (ZORDAN, 1997). 
FIGURA 4.1 - FLUXOGRAMA DO PROGRAMA EXPERIMENTAL. 58

Figura 4.2 - FluXograma dos ensaios REAlizados nO laboratóRio do Centro de PeSQUiSA E

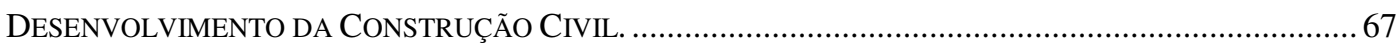

FIGURA 4.3 - EQUIPAMENTO EMPREGADO PARA A BRITAGEM DAS AMOSTRAS. ......................................69

FIGURA 4.4 - FLUXOGRAMA OPERACIONAL DE SANTO ANDRÉ................................................................ 69

FIGURA 4.5 - PENEIRADOR MECÂNICO ADAPTADO NA CENTRAL DE MOAGEM. ..........................................70

FIGURA 4.6 - SEPARAÇÃO DAS FRAÇÕES DE AGREGADOS GRAÚDOS E MIÚDOS DA AMOSTRA. .....................70

FIGURA 4.7 - ILUSTRAÇÃO DO PROCEDIMENTO DO TESTE DE FUNDO PADRÃO........................................... 71

FigurA 4.8 - PROCEDIMENTO PARA ELABORAÇÃo DAS CORRELAÇÕES DE ÁREA E VOLUME, SEM

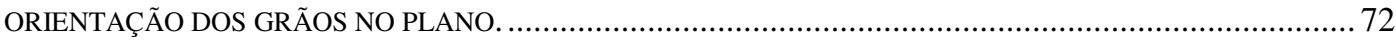

FIGURA 4.9 - PROCEDIMENTO PARA A HOMOGENEIZAÇÃO DOS MONTES DE AGREGADOS. .......................... 75

Figura 5.1 - Tentativa de SEgMENTAÇÃo DE CORES POR RGB DOS AGREGAdos COM UM FUNDO LARANJA, (A) IMAGEM ORIGINAL E (B) MÁSCARA.

FiguRA 5.2 - TENTATIVA DE SEGMENTAÇÃO DE CORES POR RGB DOS AGREGADOS DE CONCRETO COM UM FUNDO PRETO REFLEXIVO, (A) IMAGEM ORIGINAL E (B) MÁSCARA. .82

FIGURA 5.3 - DENSIDADE DA COR AZUL DO PADRÃO RGB E AS FAIXAS DE VALORES EM FUNÇÃO DAS FASES.

FIGURA 5.4 - DENSIDADE DA COR VERMELHA DO PADRÃO RGB E AS FAIXAS DE VALORES EM FUNÇÃO DAS FASES.

FIGURA 5.5 - EFEITO DA APLICAÇÃO DO FILTRO OPEN NA IMAGEM, (A) IMAGEM ORIGINAL E (B) IMAGEM

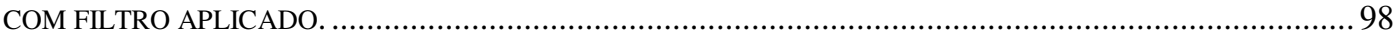

FIGURA 5.6 - EFEITO DA APLICAÇÃO DO COMANDO RESTRICT DILATION, (A) IMAGEM COM FUNDO E (B)

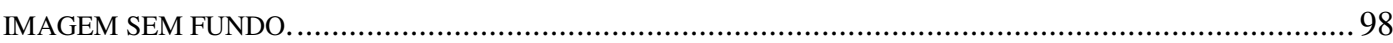

FIGURA 5.7 - CORRELAÇÃO ENTRE COMPOSIÇÕES REAIS E ESTIMADAS. ................................................. 101

FIGURA 5.8 - GERAÇÃO DE AGREGADOS MIÚDOS E GRAÚDOS, EM PERCENTUAL. .................................... 104

FIGURA 5.9 - VARIABILIDADE DAS COMPOSIÇÕES DOS AGREGADOS GRAÚDOS DE RCD NAS AMOSTRAS. 105 FIGURA 5.10 - CONTAMINAÇÕES OU MATERIAIS INDESEJÁVEIS NA COMPOSIÇÃO DOS AGREGADOS GRAÚDOS DE RCD RECICLADOS, EM PORCENTAGEM 106

FIGURA 5.11 - CONTAMINAÇÕES OU MATERIAIS INDESEJÁVEIS NA COMPOSIÇÃO DOS AGREGADOS GRAÚDOS DE RCD RECICLADOS, EM PORCENTAGEM ACUMULADA. 106

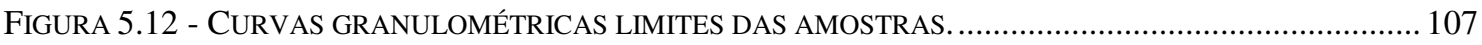

FIGURA 5.13 - CURVAS GRANULOMÉTRICAS HORÁRIAS DOS DIAS 03/02 .......................................... 108

FIGURA 5.14 - CURVAS GRANULOMÉTRICAS HORÁRIAS DO DIA 23/02 ................................................ 108

FIGURA 5.15 - TEORES DE MATERIAIS PULVERULENTOS PARA AS AMOSTRAS..................................... 109

FIGURA 5.16 - ABSORÇÃO DE ÁGUA POR IMERSÃO 24 HORAS, EM PORCENTAGEM, POR FASES NAS AMOSTRAS DOS AGREGADOS GRAÚDOS DE RCD RECICLADOS. 110 
FIGURA 5.17 - MASSA ESPECÍfICA POR FASES NAS AMOSTRAS DOS AGREGAdOS GRAÚdOS DE RCD

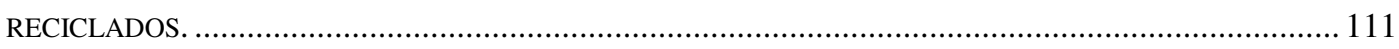

FIGURA 5.18 - VALORES DE ÍNDICE DE FORMA PARA AS AMOSTRAS. ................................................... 112

FIGURA 5.19 - VALORES DE ABSORÇÃO MÉDIA DE ÁGUA POR IMERSÃO EM 24 HORAS DAS AMOSTRAS. ... 114 FIGURA 5.20 - REGRESSÃO LINEAR ENTRE TEORES DE CONCRETO E ROCHA DA COMPOSIÇÃO COM OS VALORES DE ABSORÇÃO MÉDIA DE ÁGUA. ............................................................................... 114

FIGURA 5.21 - VALORES DE MASSA ESPECÍFICA MÉDIA DOS AGREGADOS GRAÚDOS DE RCD RECICLADOS,

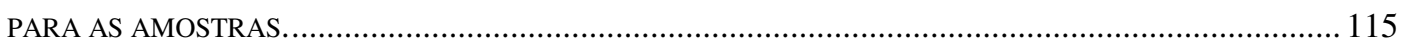

FIGURA 5.22 - REGRESSÃO LINEAR ENTRE TEORES DE ROCHA E CONCRETO E VALORES DE MASSA

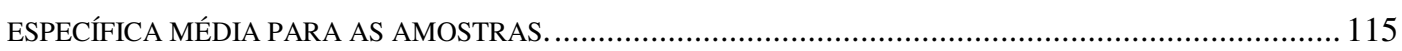

FIGURA 5.23 - REGRESSÃO LINEAR DA PORCENTAGEM DO FUNDO E A PORCENTAGEM DE ARGAMASSA DA COMPOSIÇÃO DAS AMOSTRAS. 116 


\section{LISTA DE TABELAS}

TABELA 1.1 - PARTICIPAÇÃO DOS RCD NO TOTAL DE RESÍDUOS SÓLIDOS.

TABELA 1.2 - ESTIMATIVAS DA GERAÇÃO DE RCD EM DIFERENTES PAÍSES (JOHN, 2000 MODIFICADO)... 10

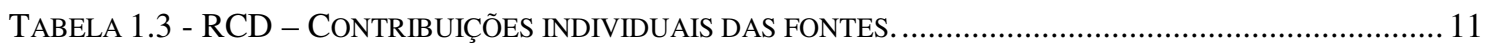

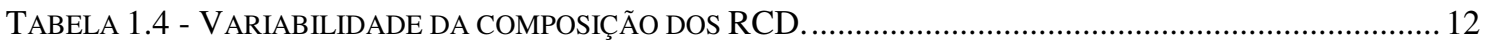

TABELA 1.5 - FONTES E CAUSAS DA OCORRÊNCIA DE RESÍDUOS DE CONSTRUÇÃO (GALIVAN; BERNOLD,

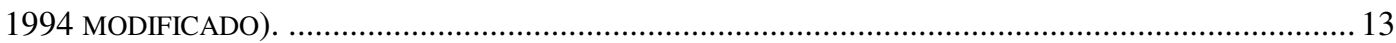

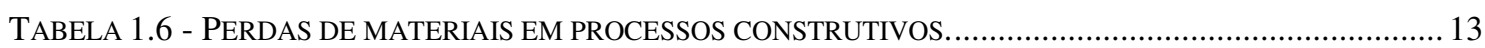

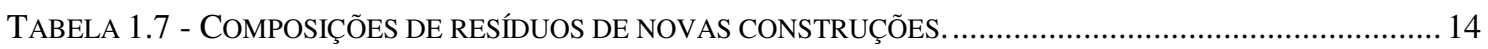

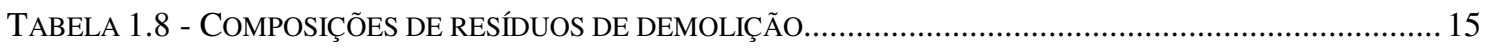

TABELA 1.9 - DESPESAS TOTAIS DE ALGUMAS MUNICIPALIDADES COM GESTÕES (PINTO, 1999),..............2 21

TABEla 2.1 - EQuiPAMENTOS DE BRITAGEM UtILIZAdOS NA RECICLAGEM DE RCD (PENG ET AL., 1997

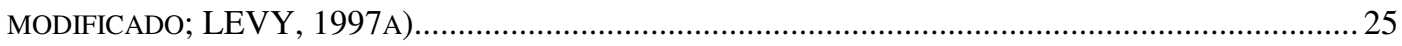

TABELA 2.2 - ASPECTOS TECNOLÓGicos RELEVANTES DE AGREGADOS DE RCD RECICLADOS E NATURAIS

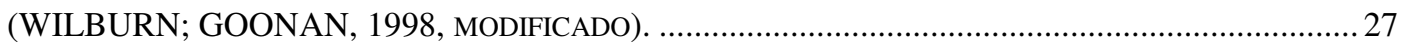

TABELA 2.3 - FONTES DE POLUENTES POTENCIAIS EM CONSTRUÇÕES. ……………………………........... 29

TABELA 2.4 - EstUdo DE DOSAGEM PARA DETERMINAÇÃO DO TRAÇO E RESISTÊNCIA À COMPRESSÃO

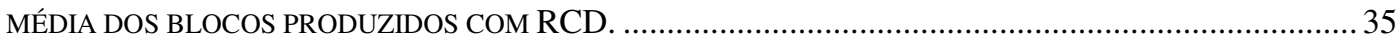

TABELA 2.5 - VARIABILIDADE DE RCD E AGREGADOS DE RCD RECICLADOS (\%, EM MASSA). ................... 37

TABELA 2.6 - VARIABILIDADE DE FASES EM AGREGADOS DE RCD RECICLADOS NA FRANÇA. .................... 38

TABELA 2.7 - FORMA DOS GRÃOS EM FUNÇÃO DAS FASES DA COMPOSIÇÃO. .............................................. 40

TABELA 2.8 - ABSORÇÃO DE ÁGUA DE ALGUNS MATERIAIS PROCESSADOS COMO AGREGADOS MIÚDOS..... 42

TABELA 2.9 - ClASSIFICAÇÃO DOS AGREGADOS GRAÚDOS DE RCD RECICLADOS PARA CONCRETO (RILEM

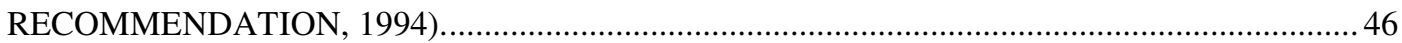

TABELA 3.1 - PARÂMETROS PARA A DIFERENCIAÇÃO DE FASES POR ANÁLISE DE IMAGEM ............................52

TABELA 3.2 - LEVANTAMENTO DOS DADOS DE AGREGADOS GRAÚDOS RECICLADOS DE CONCRETO.............54

TABELA 3.3 - LEVANTAMENTO DE DADOS DE ARGAMASSA PELA BIBLIOGRAFIA. ..........................................55

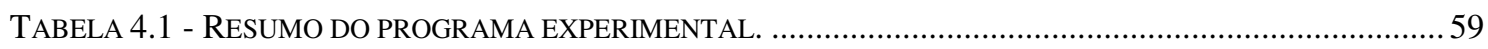

TABELA 4.2 - COMPOSIÇÕES UTILIZADAS NO ESTUDO DE SEPARAÇÃO DAS FASES. ........................................ 61

TABELA 4.3 - PARÂMETROS GERADOS PELO PROGRAMA QUE PODEM SERVIR DE CRITÉRIO DE SEPARAÇÃO DE FASES.

TABela 4.4 - Dados da composição para o estudo de CORRelaÇão entre \%A E \%V com ORIENTAÇÃO DAS CAMADAS. 
TABELA 4.5 - COMPOSIÇÃO DAS FASES DA AMOSTRA DE AGREGADOS PARA CORRELAÇÃO ENTRE \% ÁREA E $\%$ MASSA.

TABELA 4.6 - COMPOSIÇÕES ELABORADAS EM LABORATÓRIO PARA APRIMORAMENTO DA ANÁLISE DE COMPOSIÇÃO POR SEPARAÇÃO MANUAL 66

TABELA 5.1 - RESULTADOS COMPARATIVOS ENTRE AS DIMENSÕES DOS AGREGADOS. 83

TABELA 5.2 - RESUMO DOS PARÂMETROS, FASES E COMPOSIÇÕES ESTUDADAS NO PROGRAMA. 84

TABELA 5.3 - PARÂMETROS DA FASE CERÂMICA DA COMPOSIÇÃO ARGAMASSA E CERÂMICA RETIDOS EM PENEIRA NORMAL DE ABERTURA DE MALHA 12,7MM. .85

TABELA 5.4 - VALORES DE ALGUNS PARÂMETROS SELECIONADOS SEGUNDO FASES. 87

TABELA 5.5- ÁREAS ESTIMADAS DOS GRÃOS COM ORIENTAÇÃO DOS GRÃOS...........................................91

TABELA 5.6 - ÁREA DOS GRÃOS NAS CAMADAS.

TABEla 5.7 - COMPARAÇÃO ENTRE PERCENTUAL dE ÁREA E PERCENTUAL DE VOLUME DOS GRÃOS SEM

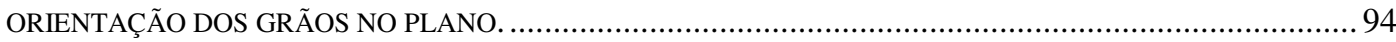

TABELA 5.8 - ÁREA DAS FASES A PARTIR DOS RESULTADOS DE ANÁLISE DE IMAGEM................................95

TABELA 5.9 - COMPOSIÇÃO PERCENTUAL DAS FASES, OBTIDAS PELO VOLUME. ......................................96

TABELA 5.10 - COMPOSIÇÃO PERCENTUAL ESTIMADA, PELA MASSA...................................................... 96

TABELA 5.11 - COMPOSIÇÃO REAL E ESTIMADA, EM PORCENTAGEM, PELA MASSA. .................................97

TABELA 5.12 - DADOS DE ABSORÇÃO DE ÁGUA E MASSA ESPECÍFICA PARA AS COMPOSIÇÕES REAIS...........99

TABELA 5.13 - VALORES MÉDIOS DE ABSORÇÃO DE ÁGUA E MASSA ESPECÍFICA PARA AS FASES CONCRETO E ARGAMASSA OBTIDOS DA LITERATURA (FIGURA 2.12). 100

TABELA 5.14 - COMPOSIÇÕES REAIS E ESTIMADAS, UTILIZANDO TRÊS EQUAÇÕES. 101

TABElA 5.15 - MASSA DE AGREGADOS GRAÚdOS E MiÚdOS COLETADAS EM CADA AMOSTRAGEM, DESCONSIDERANDO-SE AS MASSAS DE AGREGADOS DAS CONTRAPROVAS. 103

TABELA 5.16 - VALORES MÉDIOS E EXTREMOS DAS FASES DA COMPOSIÇÃO EM FUNÇÃO DAS AMOSTRAS. 105

TABELA 5.17 - VALORES MÉDIOS E EXTREMOS DOS PERCENTUAIS RETIDOS ACUMULAdOS DA GRANULOMETRIA EM FUNÇÃO DAS PENEIRAS PARA AS AMOSTRAS

TABELA 5.18 - VALORES EXTREMOS E MÉDIO PARA O TEOR DE MATERIAIS PULVERULENTOS. ... 109

TABElA 5.19 - VALORES EXTREMOS E MÉDIO PARA ABSORÇÃO DE ÁGUA POR IMERSÃO 24 HORAS, EM PORCENTAGEM. 110

TABELA 5.20 - VALORES EXTREMOS E MÉDIOS PARA MASSA ESPECÍFICA, EM FUNÇÃO DAS FASES DA AMOSTRAS 111

TABELA 5.21 - VALORES EXTREMOS E MÉDIOS PARA O ÍNDICE DE FORMA NAS AMOSTRAS. 112

TABELA 5.22 - VARIAÇÃO DA COMPOSIÇÃO DAS PILHAS DE HOMOGENEIZAÇÃO EM FUNÇÃO DO SEU TEMPO DE FORMAÇÃO. 


\section{RESUMO}

Este trabalho tem como objetivo propor uma metodologia de análise da variabilidade de agregados graúdos de RCD reciclados, que possa ser utilizada em Centrais para o controle de qualidade dos mesmos, objetivando à identificação da influência destas características no desempenho de componentes produzidos a partir dos RCD. Nos três primeiros capítulos, realiza-se uma revisão bibliográfica do assunto, identificando os pontos relevantes do tema, abordando desde Centrais de moagem até desenvolvimento sustentável. No quarto capítulo, discute-se a metodologia de análise proposta, analisando a experimentação realizada em Santo André e no laboratório de materiais de construção da Escola Politécnica da USP. No quinto capítulo, desenvolve-se a análise de resultados e discussões. Nesta etapa, é exposto o estudo da composição de agregados graúdos de RCD reciclados por análise de imagem. Apresentam-se resultados da variabilidade obtidos para os agregados graúdos reciclados de Santo André quanto a composição de fases por separação manual e outras propriedades como materiais pulverulentos, composição granulométrica, índice de forma, absorção e massa específica. Como conclusões, o estudo aponta para a presença da significativa variabilidade em agregados reciclados em todas as propriedades analisadas e a necessidade de realização das mesmas caracterizações para a fração miúda. O uso das propriedades absorção de água e massa específica para a determinação dos teores de concreto e argamassa apresentou bons resultados, aconselhando-se o emprego para a determinação das composições das fases concreto e argamassa em amostras de Centrais de Reciclagem. Os ensaios de caracterização física dos agregados graúdos naturais devem ser empregados para caracterizar esses agregados. A homogeneização da composição deve ser realizada em período superior a 2 dias para esta Central. Os agregados, quando empregados em situações mais nobres, devem possuir equipamentos de controle de qualidade, como tanques de flutuação e separação magnética. Constatouse que a porcentagem retida no fundo pelo ensaio de granulometria e os teores de argamassa têm correlação linear positiva. A análise de imagem pode ser aplicada para o estudo da composição dos agregados graúdos de RCD reciclados, pois seus princípios foram comprovados em experimentos de laboratório, quando os grãos são distribuídos de forma aleatória nos planos. 


\begin{abstract}
The main point of this research proposes one methodology which analyses the variability of coarse CDW (Construction and Demolition Waste) recycled aggregates, applied on the quality control of these aggregates. With these analysis, it can be identified the influence of this variability in components performances. In the first three chapters, it is done one review of the literature, discussing about transfer stations, sustainable development and other topics. In the fourth chapter, it is discussed the methodology, analysing the experimentation. In fifth chapter, it is presented the results and discussions. The results presents the evaluation of the composition of the coarse CDW recycled aggregates by digital image processing. There are results of the variability of coarse CDW recycled aggregates by properties like composition using manual technique, particle size distribution, particle shape analysis, absorption, specific density and fine particles $(<0,075 \mathrm{~mm})$.

To sum up, the study indicates the existence of variability in whole properties analysed and the necessity of doing characterisation on fine aggregates. One developed technique improves the evaluation of composition by manual technique, using absorption and determines the percentage on the composition of concrete and mortar phases. The other characterisations of the study developed for natural aggregates can be applied to these recycled aggregates. The variability control must be done after two days for this transfer station. In best applications, transfer stations need equipment of quality control like float tank and air classifier. It can be inferred that the percentage of fine aggregates $(<4,8 \mathrm{~mm})$ in grading test have linear correlation with percentage of mortar phase in composition. The study of composition using digital image processing obtained good results, but it is not well adequate for the necessity of transfer stations.
\end{abstract}




\section{INTRODUÇÃO}

Atualmente, a questão ambiental é discutida em diversas áreas do conhecimento. O setor industrial, em alguns casos, tem recebido atuação mais significativa do poder público pela sua indiscutível responsabilidade na geração de poluentes, como é o caso de algumas emissões atmosféricas e contaminações de cursos de água, trazendo conseqüências diretas à saúde das populações. Entretanto, no que diz respeito à construção civil, a preocupação com a geração de impactos ambientais é pouco evidente.

Sabe-se que a construção civil tem uma importante representação mundial no consumo de recursos naturais, como na geração de impactos ambientais. Ela abrange desde a fabricação de cimento e suas emissões de gás carbônico na atmosfera até a deposição de resíduos em aterros.

Nesse contexto, com a aproximação do conceito de desenvolvimento sustentável e a necessidade de novas relações da população com o meio ambiente, a construção civil deve passar por importantes transformações. Redução de desperdício, busca de melhor qualidade de seus produtos, reciclagem de seus resíduos, projetos voltados para sustentabilidade ambiental, aumento da durabilidade de componentes são exemplos de preocupações atuais no campo da pesquisa voltada para a sustentabilidade.

A atual política para os resíduos de construção e demolição é caracterizada pela ação corretiva por parte do poder público, gerando custos sociais indiretos enormes para a sociedade. Ações preventivas não são comuns, muito menos a mudança cultural necessária para a valorização de atitudes voltadas para a preservação do meio ambiente.

A reciclagem tem surgido como uma forma de amenizar a ação nociva dos resíduos no ambiente urbano, gerando ainda novos produtos comercializáveis. Desta forma, os agregados reciclados de RCD (Resíduos de Construção e Demolição) podem ser utilizados em diversos novos produtos, como argamassas, concretos e blocos de construção.

A reciclagem de resíduos deve ser abordada de forma sistêmica, pois trata-se de um problema complexo com muitas variáveis. Para a aplicação de um resíduo no 
mercado é necessário pesquisá-lo cientificamente, conhecer seu risco de contaminação e encontrar para ele aplicações potenciais, levando em consideração sua qualidade, limitações e aspectos técnico-econômicos que o cercam.

Um entrave à aplicação dos agregados reciclados de RCD é a possível variabilidade de sua composição que apresenta diferentes percentuais de argamassa, concreto, materiais cerâmicos e outros (gesso, asfalto, madeira, etc) em massa e de outras propriedades, como granulometria, absorção de água e massa específica. Não se conhecem exatamente os efeitos que essa variação pode acarretar no desempenho dos produtos gerados pela reciclagem.

Atualmente, no Brasil, existem algumas experiências na gestão de resíduos de construção e demolição, como é o caso de algumas cidades como Belo Horizonte (MG), Ribeirão Preto (SP) e recentemente Salvador (BA). O que se constata em todos os casos é uma melhora na qualidade ambiental. Porém os processos de reciclagem de RCD em centrais de moagem não estão bem explorados, limitando-se à geração de materiais reciclados voltados para o consumo público municipal. Este consumo é insuficiente para solucionar o problema como um todo, considerando-se a quantidade total de RCD gerada no município.

Sendo as municipalidades e órgãos públicos incapazes de absorverem a oferta de matéria-prima, mesmo considerando-se as grandes necessidades de pavimentação de vias públicas, deve-se considerar o mercado privado para esses resíduos. Para estes casos, porém, os agregados reciclados de RCD gerados não possuem características suficientemente homogêneas nem contam com um controle de variabilidade. Também não se utilizam os equipamentos disponíveis para a melhoria de qualidade desses agregados, como tanques de depuração por flutuação e classificadores por ar.

Essa heterogeneidade das propriedades dos agregados reciclados de RCD é responsável pela limitação de sua aplicação em algumas situações, como concretos estruturais, blocos e argamassas. Por outro lado, gera, com sucesso, aplicação em situações de menor exigência de qualidade, como na pavimentação. Isso só prejudica a inserção desses agregados em mercados consumidores privados.

Considera-se, então, que conhecer a composição e outras propriedades dos agregados reciclados de RCD constitui um primeiro passo para se poder avaliar o desempenho do produto produzido a partir desses resíduos. Pois, a partir de suas 
composições e demais propriedades, é possível determinar de forma adequada a influência da composição e dessas propriedades no desempenho do produto reciclado.

Permite, ainda, uma previsibilidade do desempenho do produto em função de sua composição e outras propriedades, auxiliando empresas que se interessem por utilizar essa "nova matéria prima" em seu processo produtivo.

\section{OBJETIVOS DO TRABALHO}

Os objetivos específicos deste trabalho são:

- Estudar a aplicação da técnica de análise de imagem para a avaliação da composição dos agregados graúdos de RCD reciclados,

- Quantificar a variabilidade da composição e características físicas desses agregados.

\section{HISTÓRICO DOS RCD NO EXTERIOR E NO BRASIL}

A primeira importante menção aos $\mathrm{RCD}$ ocorreu após o final da $2^{\mathrm{a}}$ guerra mundial, quando surgiu a necessidade de remover ruínas e houve uma demanda crescente de materiais. Para este caso, o entulho dos edifícios demolidos foi britado como agregados, sendo desta forma reciclado. (WEDLER; HUMMEL, 1946 apud LEVY, 1997).

No período de 1976 a 1982, na Europa, ocorreu a formação do comitê técnico da RILEM (Réunion Internacionale des Laboratoires d'Essais et de Recherches sur les Matériaux et les Construction) TC 37 DRC, tendo como objetivo estudar as técnicas de demolição e aspectos técnicos relacionados a reutilização (sic) do concreto em componentes reciclados, envolvendo pesquisadores como EVERETT, DE PAUW e HANSEN em países como Holanda, França, Inglaterra, Bélgica e Japão. Após 1988, esse comitê passa a ser RILEM 121-DRG.

As pesquisas até 1982, preocupadas quase que exclusivamente com a reciclagem do concreto, sofreram modificações a partir de 1985 com os outros Simpósios da RILEM, interessando-se também por demolição e reaproveitamento do concreto e alvenaria. Entre 1985 e 1993 ocorreram 3 simpósios internacionais da RILEM, respectivamente em Holanda, Japão e Dinamarca.

O $3^{\mathrm{o}}$ Simpósio Internacional de Demolição e Reuso (sic) do concreto e alvenaria já reflete o aumento da necessidade mundial de reciclar concretos e alvenaria. 
Contou com importantes órgãos promotores, tais como ACI (American Concrete Institute), ISWA (International Solid Waste Association), ENBRI (European Network of Building Research Institutes) e CIB (International Council for Research and Innovation in Building and Construction). Ao lado de questões meramente tecnológicas já se apontava para a necessidade de planejamento integrado das atividades de demolição, reciclagem e gerenciamento de resíduos. Constatou-se no evento a não existência de razões técnicas e econômicas para impedir a reciclagem, e o objetivo mundial era reduzir as cargas de aterros e o uso de recursos naturais.

Esse simpósio destacou (LAURITZEN,1994):

a importância de legislação e regulamentação para os RCD;

$>$ a necessidade de integração entre indústria da construção e o poder público;

$>$ a evolução das técnicas de demolição, como o desmantelamento;

$>$ a revisão de especificações para uso de agregados reciclados em pavimentação;

$>$ a necessidade de planejamento das demolições com apresentação de um guia para demolição e reuso (sic) de materiais após terremotos e desastres.

Estudos e conclusões sobre a utilização de agregados reciclados de concreto na produção de concreto têm demonstrado boa viabilidade técnica (HANSEN,1992; WAINWRIGHT et al., 1994; MERLET; PIMIENTA, 1994; KIKUCHI et al., 1994; YANAGI et al., 1994).

Em 1994 o comitê 121-DRG da RILEM apresentou ao mercado a especificação de agregados reciclados de RCD para a produção de concretos (RILEM,1994).

Desse período em diante realizaram-se inúmeros congressos, aumentando o número de comitês relacionados com meio-ambiente, RCD e construção. Destacam-se:

> "Environmental Aspects of Construction with Waste Materials", no ano de 1994, conferência denominada WASCON, editadas pela Elsevier, promovida pela ISCOWA (The International Society for the Environmental and Technical Implications of Construction with alternative materials);

$>$ "International Conference of CIB TG 16 - Sustainable Construction", na cidade de Gainesville, Universidade da Flórida, em 1994;

$>$ "Second International Conference Buildings and the Environment", realizada em Paris, no ano de 1997, pelo CSTB (Céntre Scientifique et Technique du Bâtiment), com apoio do CIB; 
> "Waste Materials in Constructions: Putting theory into practice", no ano de 1997, conferência denominada WASCON, editadas pela Elsevier, promovida pela ISCOWA;

$>$ "CIB World Building Congress - Materials and Technologies for sustainable construction", realizado em 1998, na Suíça.

Em todos os eventos, desenvolvem-se temas que abordam tecnologias de reciclagem, aplicação de resíduos na construção, avaliação de impacto ambiental, gerenciamento de resíduos, etc.

No Brasil, os estudos de resíduos aplicados à construção civil, bem como sua reciclagem, iniciaram-se com CINCOTTO (1983) e PINTO (1986). Recentemente a pesquisa sobre reciclagem vem crescendo, com autores como LEVY (1997a), ZORDAN (1997), MIRANDA (2000) entre outros, que abordam a reciclagem tanto para concretos como para argamassas. Porém pouco se conhece sobre a variabilidade dos agregados e sua influência sobre os componentes. Sabe-se, no entanto, que a reciclagem é um processo viável técnica e economicamente, com reflexos significativos na qualidade ambiental urbana.

PINTO (1999) abordou aspectos mais abrangentes da gestão dos resíduos de construção e demolição, trazendo importantes contribuições para a sustentabilidade, avaliando aspectos econômicos, urbanos, sociais e políticos. Identificou que a primeira central de moagem de entulho apareceu em 1991, na cidade de São Paulo.

Em 1996, foi criado o Comitê Técnico 206 - Meio Ambiente, do IBRACON (Instituo BRAsileiro do CONcreto), para estabelecer potencialidades e limitações do uso dos resíduos industriais, de mineração e da construção civil para emprego no concreto (KIHARA; MARCIANO, 1997).

Até o presente momento houve três reuniões deste comitê, enriquecendo o assunto com artigos técnicos que abordam aspectos tecnológicos, de gestão e de desenvolvimento sustentável.

A ANTAC (Associação Nacional de Tecnologia do Ambiente Construído) também possui um grupo de trabalho na área de aplicação de resíduos na construção civil. 


\section{ESTRUTURA DO TRABALHO}

Cinco capítulos organizam este trabalho. No primeiro, apresentam-se definições, quantitativos, origens e conseqüências ambientais da deposição dos RCD. O segundo capítulo, trata da reciclagem dos RCD como agregados, do processo de produção, da presença de contaminações e materiais indesejáveis para a utilização. Considera o emprego em componentes reciclados, como blocos, concretos e argamassas, considerando a variabilidade encontrada na composição e outras propriedades de agregados reciclados de RCD, bem como a influência dessa variabilidade no desempenho de argamassas e concretos. No último item desse capítulo discute-se a normalização de agregados reciclados para a aplicação em concretos.

No terceiro capítulo, abordam-se os métodos que podem ser empregados para a caracterização da composição dos agregados reciclados de RCD.

O quarto capítulo propõe um programa experimental para a avaliação da variabilidade de agregados graúdos reciclados de RCD. Apresenta o desenvolvimento e a aplicação de um método de caracterização da composição desses agregados por análise de imagem e sugere o uso de absorção de água e massa específica para a determinação dos teores de concreto e argamassa da composição.

O quinto capítulo é dedicado à análise de resultados e conclusões.

Os três primeiros capítulos realizam também a revisão bibliográfica do assunto. Os dois últimos focalizam procedimentos experimentais e analisam resultados. 


\section{RESIIDUOS DE CONSTRUÇÃO E DEMOLIÇÃO}

\subsection{DEFINICÕES}

Alguns autores preferem o termo RCD para resíduos de construção e demolição; outros utilizam o termo entulho. Quanto à definição, há discordâncias não só quanto à abrangência das frações presentes, como também quanto às atividades geradoras dessas frações.

LEVY (1997a) define entulho de construção civil como a parcela mineral dos resíduos provenientes das atividades de construção e demolição. Esta definição não considera atividades envolvidas em infraestrutura (como sistemas de drenagens e estradas) e obras de arte e nem a parcela orgânica do entulho, como tubos de PVC. ${ }^{1}$

HONG KONG POLYTECHNIC (1993) apud LEVY (1997a) define entulho de construção civil de forma mais abrangente que LEVY (1997a), considerando atividades de obras de arte de engenharia civil.

Encontramos na literatura várias definições para resíduos de construção e demolição, como em BOSSINK; BROUWERS (1996), PERA (1996), COLLINS (1997), HARDER; FREEMAN (1997) e ZORDAN (1997).

Para BIOCYCLE (1990), apud ZORDAN (1997), RCD são “resíduos sólidos não contaminados, provenientes de construção, reforma, reparos e demolição de estruturas e estradas, e resíduos sólidos não contaminados de vegetação, resultantes de limpeza e escavação de solos. Como resíduos, incluem-se, mas não limitam-se, blocos, concreto e outros materiais de alvenaria, solo, rocha, madeira, forros, argamassa, gesso, encanamentos, telhas, pavimento asfáltico, vidros, plásticos que não camuflem outros resíduos, fiação elétrica e equipamentos que não contenham líquidos perigosos e metais que estiverem num dos itens acima. ".

Como se vê, nesta definição consideram-se materiais de natureza orgânica, como a madeira, fiação elétrica e encanamentos e também limpeza e escavação de

${ }^{1}$ Entende-se como parcela orgânica do entulho os materiais constituídos a base de carbono. 
solos; porém utiliza a expressão "não contaminado", o que não parece pertinente, uma vez que a contaminação é inerente ao resíduo e pode estar presente. Trata-se, neste caso, da vegetação presente na limpeza de terrenos.

Causam polêmica as atividades de manutenção ou reparos, consideradas na definição de RCD mencionada acima. As atividades de reparos são parte das atividades de construção civil, devendo, portanto, ser consideradas, pois, em razão da natureza da atividade, seus resíduos devem se assemelhar aos de demolição.

Para este trabalho, consideram-se RCD todo e qualquer resíduo oriundo das atividades de construção, seja ele de novas construções, reformas, demolições, que envolvam atividades de obras de arte, solos ou resíduos de vegetação presentes em limpezas de terreno. Inclui-se aqui a vegetação, pois a contaminação é inerente ao resíduo, conforme mencionado acima.

Quanto ao termo entulho, parece ser bastante amplo, sendo preferível a utilização do termo RCD, que remete diretamente à idéia da natureza dos resíduos, provenientes, portanto, de atividades da construção e demolição.

\subsection{QUANTIDADE GERADA DE RCD}

Quantificar RCD é difícil. A quantificação pode ser realizada através de, pelo menos, três formas: por área construída, movimentação de cargas por coletores e monitoramento de descargas. Este último sistema de quantificação é difícil de ser realizado, por causa da pulverização das descargas no ambiente urbano (PINTO, 1999).

Nos estados brasileiros há carência de informações sobre as características dos resíduos de construção e demolição. No quadro de composição de resíduos sólidos urbanos, os lixos domésticos são considerados predominantes e centralizam as ações dos planos diretores. Neste caso, esses resíduos são considerados críticos para o esgotamento de aterros (BORGES, 2000; MASSUNARI, 2000; ORTH, 2000).

Por outro lado, na realidade das cidades de médio e grande porte, a presença dos RCD é significativa. Em um levantamento realizado na cidade de Santo André, os RCD aparecem como 58\% do total em massa de RSU (Resíduos Sólidos Urbanos), com apenas 33\% de participação dos resíduos domiciliares (PINTO, 1999).

Esta realidade de grande participação dos RCD no total de resíduos sólidos urbanos também é evidenciada em outros países, conforme se observa na Tabela 1.1. 
Tabela 1.1 - Participação dos RCD no total de resíduos sólidos.

\begin{tabular}{|c|c|c|}
\hline Países & RCD (\%), em massa & Ano \\
\hline Países baixos $^{1}$ & 26 & 1996 \\
\hline Austrália $^{1}$ & $20-30$ & 1994 \\
\hline Estados Unidos $^{1}$ & $20-39$ & $1994 / 1998$ \\
\hline Alemanha $^{1}$ & 19 & 1994 \\
\hline Finlândia $^{1}$ & $13-15$ & 1994 \\
\hline Brasil $^{2}$ & $54-67$ & 1999 \\
\hline Inglaterra $^{3}$ & 17 & 1997 \\
\hline Holanda $^{4}$ & $13-30$ & 1998 \\
\hline Bélgica $^{5}$ & 66 & 1994 \\
\hline Europa Ocidental $^{6}$ & 66 & 1996 \\
\hline
\end{tabular}

${ }^{1}$ BOSSINK; BROUWERS (1996).

${ }^{2}$ PINTO (1999) (valores de apenas algumas cidades).

${ }^{3}$ HARDER; FREEMAN (1997).

${ }^{3}$ CRAIGHILL; POWELL (1997).

${ }^{4}$ WILSON et al. (1998).

${ }^{5}$ LAURITZEN (1994).

${ }^{6}$ PERA (1996).

Percebe-se que o percentual de participação dos RCD nos resíduos sólidos é bastante variável nos países considerados. Provavelmente, este fato se deve ao sistema de informação da geração do resíduo, pois sabe-se que o levantamento nas áreas de descarte é de difícil quantificação, em virtude da quantidade de áreas receptoras pulverizadas na malha urbana. Deve-se também às tecnologias e materiais empregados em cada país, bem como a idade das cidades, com maior ou menor quantidade de atividades de construção e de demolição, considerando-se a diferença da quantidade de resíduos gerados pelas atividades de demolição, se comparada com a quantidade de resíduos gerados pelas atividades de construção. Deve-se considerar ainda, a abrangência das definições nesses diferentes países, consideradas diferentes das definições encontradas na literatura.

Um importante índice a ser obtido é a geração de RCD per capita. Para o atual momento, pode-se utilizar, como estimativa não muito precisa de RCD por habitante, a média de algumas cidades brasileiras que é de 0,50 tonelada/ habitante $\mathrm{x}$ ano (PINTO,1999). Ressalta-se que mais caracterizações são necessárias para se adotar um valor mais representativo; além disso podem existir diferenças significativas da média em relação à geração de um município de pequeno porte, por exemplo. PERA (1996) aplica o índice de 0,7-1,0 tonelada/habitante x ano para a Europa Ocidental.

A seguir, mostra-se a estimativa desse índice para diversos países e sua variação, na Tabela 1.2. Percebe-se que os dados ainda são desencontrados e as estimativas muito imprecisas. 
Tabela 1.2 - Estimativas da geração de RCD em diferentes países (JOHN, 2000 modificicado).

\begin{tabular}{|c|c|c|}
\hline Países & Quantidade (kg/ hab) & Observações \\
\hline Suécia & $136-680$ & 1996 \\
\hline Holanda & $820-1300$ & 1996 \\
\hline EUA & $463-584$ & 1995,1996 \\
\hline Inglaterra & $880-1120$ & 1990,1992 \\
\hline Bélgica & $735-3359$ & \\
\hline Dinamarca & $440-2010$ & 1994,1996 \\
\hline Itália & $600-690$ & 1995 \\
\hline Alemanha & $963-3658$ & Exclui solos \\
\hline Japão & 785 & Algumas cidades apenas \\
\hline Portugal & 325 & \\
\hline Brasil & $230-660$ & \\
\hline
\end{tabular}

Novamente, os fatores acima mencionados sobre a participação dos RCD no total de RSU devem ser a causa dessa imprecisão observada.

\subsection{COMPOSIÇÃO, VARIABILIDADE E ORIGEM DOS RCD}

\subsubsection{Composição dos RCD}

A composição dos RCD é gerada durante novas construções, reformas/manutenção e demolições. Considera-se que, em razão da natureza da atividade, a composição dos resíduos de reformas/manutenção deve se assemelhar a de resíduos de demolição, porém não há informações a respeito.

O percentual de participação das diferentes origens na geração dos RCD é variável em diversos países. Nas previsões para o ano 2000 da Europa Ocidental percebe-se um aumento da participação dos resíduos de demolição no total de RCD, com queda da atividade de construção e aumento de atividade de manutenção, reabilitação e demolição. Países como o Brasil, em que as atividades de construção são mais intensas, essa relação pode chegar a 1:1 em comparação com os resíduos de demolição (PINTO, 1999). Conclusões que podem ser observadas na Tabela 1.3. 
Tabela 1.3 - RCD - Contribuiições individuais das fontes.

\begin{tabular}{|c|c|c|c|c|c|c|}
\hline País & $\begin{array}{c}\text { RCD } \\
\text { (ton/ano) }\end{array}$ & $\begin{array}{l}\text { Resíduos de } \\
\text { construção } \\
\text { (ton/ano) }\end{array}$ & $\begin{array}{c}\text { Resíduos de } \\
\text { demolição } \\
\text { (ton/ano) }\end{array}$ & $\begin{array}{l}\text { \% de resíduo } \\
\text { de construção } \\
\text { no } R C D\end{array}$ & $\begin{array}{c}\text { \% de resíduo } \\
\text { de demolição } \\
\text { no } \mathrm{RCD}\end{array}$ & Ano \\
\hline Países baixos ${ }^{3}$ & 14 milhões & & & & & 1996 \\
\hline Inglaterra $^{5}$ & 70 milhões & & & & & 1997 \\
\hline Alemanha $^{7}$ & 32,6 milhões & 10 milhões & 22,6 milhões & 31 & 69 & 1994 \\
\hline $\begin{array}{l}\text { Estados } \\
\text { Unidos }\end{array}$ & 31,5 milhões & 10,5 milhões & 21,0 milhões & 33 & 66 & $1994 / 1997$ \\
\hline $\mathrm{Brasil}^{2}$ & 70 milhões $^{8}$ & 35 milhões & 35 milhões & $30-50$ & $50-70$ & 1999 \\
\hline Japão $^{7}$ & 99 milhões & 52 milhões & 47 milhões & 52 & 48 & 1993 \\
\hline França $^{6}$ & & & 25,0 milhões & & & 1994 \\
\hline $\begin{array}{c}\text { Europa } \\
\text { Ocidental }^{1}\end{array}$ & 215 milhões & 40 milhões & 175 milhões & 19 & 81 & $\begin{array}{c}\text { Previsão } \\
2000\end{array}$ \\
\hline
\end{tabular}

${ }^{1}$ PERA (1996); HENDRICKS (1993) apud. QUEBAUD;BUYLE-BODIN (1999)

${ }^{2}$ PINTO (1999); ZORDAN (1997); JOHN (2000)

${ }^{3}$ BOSSINK;BROUWERS (1996)

${ }^{4}$ PENG et al. (1997)

${ }^{5}$ CRAIGHILL; POWELL (1997)

${ }^{6}$ GIRARDOT (1994) apud QUEBAUD;BUYLE-BODIN (1999)

${ }^{7}$ LAURITZEN (1994)

${ }^{8}$ Para esta estimativa, foi considerada uma população de 150 milhões de habitantes, com uma geração anual de 0,5 ton/hab.ano, média obtida de algumas cidades brasileiras em PINTO (1999). Ressalta-se que não se trata de uma média representativa.

\subsubsection{Variabilidade dos $R C D$}

A variabilidade dos RCD pode ocorrer em novas construções, na manutenção e decorrer de diferentes tecnologias construtivas. Em novas construções essas variações ocorrem em função do cronograma de execução de serviços, fazendo com que, em cada período, os materiais e índices de perdas dos mesmos sejam bem diferentes.

$\mathrm{Na}$ manutenção, apesar de serem atividades que envolvem menos tempo de execução, a composição também é variável, uma vez que as áreas reparadas são variáveis, diversificando materiais em função do tipo de reforma.

Quanto às tecnologias construtivas, há diferenças quanto aos materiais disponíveis e técnicas construtivas. PINTO (1999) analisa que a madeira é muito presente nos RCD nas construções americanas e japonesas, sendo menos significativa no Brasil. HARDER;FREEMAN (1997) afirmam ser surpreendente a quantidade de 
madeira presente em aterros no sul da Inglaterra. O gesso, por sua vez, é muito utilizado na Europa e Estados Unidos.

Todos esses fatores causam variabilidade na composição dos RCD. A variabilidade pode ser confirmada, na análise das composições médias obtidas no Brasil em duas cidades diferentes, conforme a Tabela 1.4.

Tabela 1.4 - Variabilidade da composição dos RCD.

\begin{tabular}{|c|c|c|}
\hline Composição & São Paulo $^{\mathbf{1}}$ & \multirow{2}{*}{ Salvador $^{2}$} \\
\hline Concreto & $8 \%$ & $53 \%$ \\
\hline Argamassa & $24 \%$ & $15 \%$ \\
\hline Materiais cerâmicos & $33 \%$ & $21 \%$ \\
\hline Solos & $30 \%$ & $4 \%$ \\
\hline Materiais orgânicos & $1 \%$ & $7 \%$ \\
\hline Outros & $4 \%$ & 5 \\
\hline
\end{tabular}

BRITO (1999).

${ }^{2}$ CARNEIRO et al. (2000).

\subsubsection{Origem dos resíduos de novas construções}

Nas atividades de construção, os resíduos de novas construções são originados das perdas físicas oriundas de canteiros de obra. Há também uma parcela das perdas que permanece incorporada na forma de espessuras, além das perdas usuais. Para PINTO (1995), o entulho produzido na obra representa 50\% da massa total de material desperdiçado. SOUZA et al. (1999) falam em valores de 20 a $30 \%$.

ANDRADE (1999) define como desperdício a fração das perdas que excede o limite mínimo característico da tecnologia, considerada inevitável para determinado nível tecnológico. SOUZA et al. (1999) definem perdas de materiais como um consumo de materiais além do necessário à produção ou manutenção de um bem.

A perda física em massa pode não ter o mesmo significado quando analisada em termos financeiros, introduzindo-se, então, o conceito de perda financeira. PICCHI (1993) considera que o entulho gerado pode representar 5\% de perda financeira no custo de uma obra.

A construção artesanal, predominante na construção civil brasileira, contribui para a existência de perdas consideráveis de materiais e mão-de-obra. Impera o princípio da baixa produtividade e mau gerenciamento (ZORDAN, 1997; PINTO, 1986).

A Tabela 1.5 mostra as principais fontes e causas da ocorrência de resíduos de construção. 
Tabela 1.5 - Fontes e causas da ocorrência de resíduos de construção (GALIVAN;

BERNOLD, 1994 modificado).

\begin{tabular}{|l|ll|}
\hline \multicolumn{1}{|c|}{ Fonte } & & \multicolumn{1}{c|}{ Causa } \\
\hline \multirow{2}{*}{ Projeto } & - & Erro nos contratos. \\
& - & Contratos incompletos. \\
& - & Modificações de projeto. \\
\hline Intervenção & - & Ordens erradas, ausência ou excesso de ordens. \\
& - & Erros no fornecimento. \\
\hline Manipulação de materiais & - & Danos durante o transporte. \\
& - & Estoque inapropriado. \\
\hline & - & Erros do operário. \\
& - & Mau funcionamento de equipamentos. \\
& - & Ambiente impróprio. \\
Operação & - & Dano causado por trabalhos anteriores e posteriores. \\
& - & Uso de materiais incorretos em substituições. \\
& - & Sobras de cortes. \\
& - & Sobras de dosagens. \\
& - & Resíduos do processo de aplicação. \\
\hline Outros & - & Vandalismo e roubo. \\
& - & Falta de controle de materiais e de gerenciamento de resíduos. \\
\hline
\end{tabular}

PALIARI (1999) realizou uma revisão nas pesquisas sobre perdas de materiais no país e no exterior. $\mathrm{O}$ autor cita que as primeiras informações sobre perdas foram obtidas na Inglaterra, através do BRE (Building Research Establishment), pela publicação de SKOYLES (1976), embora os primeiros estudos datem de 1963. No Brasil, o autor cita estudos de perdas por alguns autores como PINTO (1989), PICCHI (1993); SOIBELMAN (1993) e LIRA (1997).

A pesquisa nacional "Alternativas para a redução do desperdício de materiais nos canteiros de obras", realizada pelo ITQC (Instituo Brasileiro de Tecnologia e Qualidade na Construção Civil), com recursos da FINEP, obteve dados recentes de perdas aplicando uma metodologia própria, conforme mostra a Tabela 1.6 (PALIARI, 1999; PINTO, 1999; SOUZA et al., 1999).

Tabela 1.6 - Perdas de materiais em processos construtivos.

\begin{tabular}{|c|c|c|c|}
\hline Perdas Materiais & Mediana & Mínimo & Máximo \\
\hline Concreto usinado & $9 \%$ & $2 \%$ & $23 \%$ \\
\hline Aço & $11 \%$ & $4 \%$ & $16 \%$ \\
\hline Blocos e tijolos & $13 \%$ & $3 \%$ & $48 \%$ \\
\hline Cimento & $56 \%$ & $\mathrm{Nd}$ & $\mathrm{Nd}$ \\
\hline Cal & $36 \%$ & $\mathrm{Nd}$ & $\mathrm{Nd}$ \\
\hline Areia & $44 \%$ & $\mathrm{Nd}$ & $\mathrm{Nd}$ \\
\hline \multicolumn{3}{|l}{}
\end{tabular}

PINTO (1999) observa que existiu uma tendência de crescimento das atividades de construção superior ao crescimento populacional, no período posterior aos 
anos de 1994 e 1995, atribuída pelo autor à redução de taxas inflacionárias no país. Isto pode ser considerado um fator complicador na geração de resíduos.

A Tabela 1.7 mostra algumas composições de resíduos de novas construções. Novamente observa-se variabilidade na composição em função do país. Destaca-se a predominância mineral nesses resíduos.

Tabela 1.7 - Composições de resíduos de novas construções.

\begin{tabular}{|c|c|c|c|}
\hline \multirow{2}{*}{ Materiais } & \multicolumn{3}{|c|}{ Resíduo de construção, em massa (\%) $^{3}$} \\
\cline { 2 - 4 } & Holanda $^{1}$ & Japão $^{2}$ & Brasil $^{3}$ \\
\hline Cerâmica & 39 & 12 & 29 \\
\hline Madeira & 17 & 19 & 4 \\
\hline Concreto & 13 & 17 & $\mathrm{Nd}$ \\
\hline $\begin{array}{c}\text { Tijolos e elementos } \\
\text { sílico-calcáreos }\end{array}$ & 14 & 1 & 64 \\
\hline Argamassas & 8 & $\mathrm{Nd}$ & 3 \\
\hline $\begin{array}{c}\text { Outros (plásticos, solos, } \\
\text { papel, mat. orgânica) }\end{array}$ & 9 & 51 & \multicolumn{2}{c}{} \\
\hline
\end{tabular}

${ }^{1}$ BOSSINK;BROUWERS (1996)

${ }^{2}$ HONG KONG POLYTECHNIC (1993) apud LEVY (1997a)

${ }^{3}$ PINTO (1986)

Observou-se que os resíduos de construção, gerados em canteiros na Holanda, decorrem de algumas etapas construtivas, tais como fundações, alvenaria, forros e telhados e que estes representam $67 \%$ dos custos totais com resíduos de construção. Foram empregados em tais etapas, concretos, argamassas, tijolos de cal e areia e cerâmica. Grande quantidade dos resíduos de construção é causada por uma pequena variedade de materiais (BOSSINK; BROUWERS,1996).

\subsubsection{Origem dos resíduos de demolição}

Os resíduos de demolição são caracterizados por concretos e tijolos, com menores quantidades de aço, plástico e madeira (WOOLLEY, 1994). Possuem uma larga extensão de materiais, mas incluem substâncias tóxicas em sua composição, tais como fenóis, sulfatos, metais pesados, que não devem passar, no entanto, de $1 \%$ da massa (TRANKLER et al., 1995; WAHLSTROM et al., 1996; MULDER, 1997).

$\mathrm{Na}$ cidade de Londrina foi constatado que as técnicas tradicionais de demolição em edificações de poucos andares são rudimentares, pois utilizam processos manuais. Acredita-se que o mesmo deva ocorrer nas demais cidades brasileiras (ANGULO, 1998). Existem processos de demolição mais sofisticados para demolição de edifícios de múltiplos andares, empregando-se equipamentos especiais. 
Atualmente, há técnicas de demolição seletiva, que organizam os processos de demolição para a retirada de certos materiais indesejáveis ou reaproveitamento de outros. Esta técnica pode ser empregada para a obtenção de agregados reciclados de resíduos de demolição de melhor qualidade, retirando possíveis contaminantes, como o gesso. O tempo gasto com tal processo é maior que em demolições tradicionais (WAHLSLTROM et al., 1996; RUCH et al., 1997; SCHULTMANN et al., 1997).

O não-emprego dos processos de demolição seletiva, na França, gera agregados de composição variável com contaminação de gesso, sendo esta contaminação a principal causa de patologia de agregados de RCD reciclados (GALLIAS, 1998).

A ocorrência de desastres naturais em cidades, tais como terremotos, contribuem para aumentar a quantidade de resíduos de demolição. Nesses casos, podem existir resíduos tóxicos, como o amianto, incorporados em partículas finas (LAURITZEN, 1998).

A seguir, na Tabela 1.8, podem-se observar algumas composições de resíduos de demolição. Nota-se novamente variabilidade em função dos países envolvidos e pelo fato de que grande parte da composição é representada por compostos inorgânicos. Percebe-se um aumento significativo da quantidade de concreto na composição, quando comparada com a composição de resíduos de novas construções, provavelmente por causa da demolição de vigas, pilares e lajes de concreto armado, quando esta tecnologia foi empregada.

Tabela 1.8 - Composições de resíduos de demolição.

\begin{tabular}{|c|c|c|}
\hline \multirow[b]{2}{*}{ Materiais } & Alemanha $^{1}$ & Japão $^{2}$ \\
\hline & $\begin{array}{l}\text { Residuo de demolição, } \\
\text { em produção }\end{array}$ & $\begin{array}{c}\text { Residuo de demolição, } \\
\text { em massa }(\%)\end{array}$ \\
\hline Cerâmica & $1^{\circ}$ & 6,33 \\
\hline Madeira & $3^{\circ}$ & 7,14 \\
\hline Concreto & $2^{\circ}$ & 54,26 \\
\hline Gesso/ Argamassas & $4^{\circ}$ & $\mathrm{Nd}$ \\
\hline Outros & $5^{\circ}$ & 32,27 \\
\hline
\end{tabular}

${ }^{1}$ SCHULTMANN et al. (1997).

${ }^{2}$ HONG KONG POLYTECHNIC (1993) apud LEVY (1997a).

\subsection{CONSEQÜENCIAS AMBIENTAIS DA DEPOSIÇÃO DE RCD}

Os RCD, dentro do contexto urbano, causam impactos dos mais variados. Além dos ambientais, há os impactos econômicos e sociais. 
A pouca preocupação com o destino do entulho gera "bota-fora" e aterros clandestinos, degradação de áreas urbanas, assoreamento de córregos e entupimento de bueiros e galerias, tanto no Brasil como no exterior (GAVILAN; BERNOLD, 1994; ZORDAN, 1997; BRITO, 1999).

A deposição de entulho em áreas públicas e córregos causa custos sociais , graças à necessidade de desassoreamento de córregos, canais e rios, limpeza de ruas e terrenos públicos, além de queda da qualidade de vida dos moradores em áreas próximas a despejos clandestinos (PINTO, 1986; BRITO, 1999).

A Figura 1.1 mostra a obstrução de uma rua asfaltada no bairro do Morumbi, em São Paulo, por RCD.

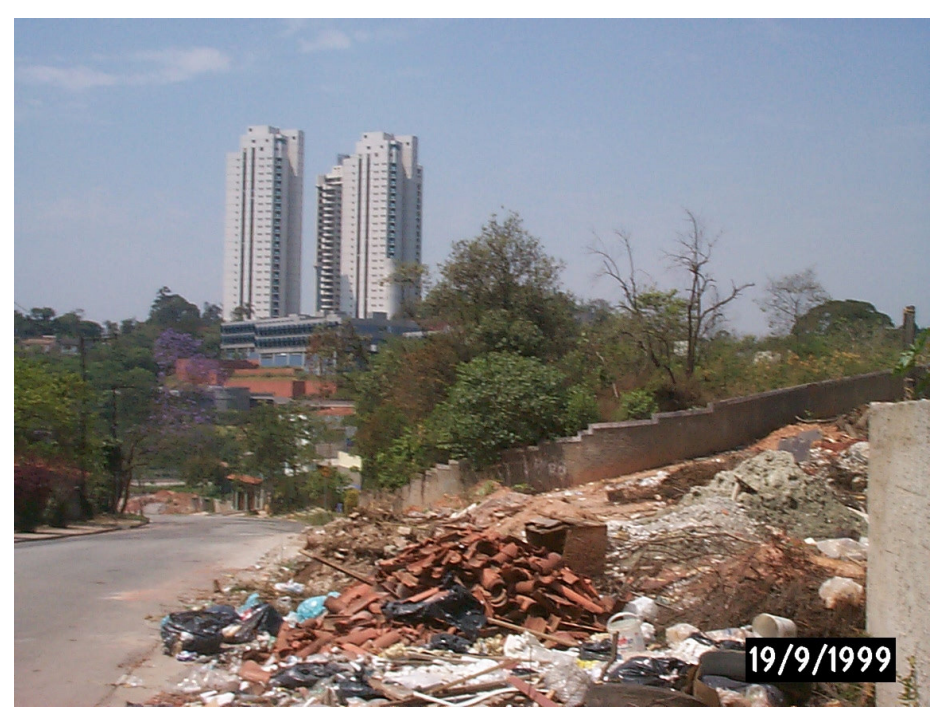

Figura 1.1 - Obstrução de rua em São Paulo por RCD. Fonte: Vanderley M. John.

Em locais de "bota-foras" e de despejos irregulares é comum a presença de roedores, aranhas, escorpiões e insetos transmissores de endemias (PINTO, 1999).

A solução mais comum para a problemática gerada pelos RCD no meio urbano era a deposição em aterros. Surgiram, porém, problemas como escassez de novos aterros em grandes cidades, além de tornarem-se cada vez mais distantes. (GAVILAN; BERNOLD, 1994; ZORDAN, 1997).

Sabe-se também, pelos estudos mais recentes, que aterros podem sofrer problemas de lixiviação e contaminar o lençol freático pelos resíduos ali depositados, inclusive os RCD (PENG et al., 1997). 


\subsection{POLÍTICAS PÚBLICAS PARA RCD}

Diversos países têm desenvolvido regulamentações que buscam direcionar as atividades da construção civil para o conceito de desenvolvimento sustentável (TUKKER; GIELEN, 1994; YATES; HAMPTON, 1997; SCHULTMANN et al., 1997; WILBURN; GOONAN, 1998).

ZWAN (1997) define desenvolvimento sustentável como o que fornece as necessidades da geração atual, sem comprometer as da geração futura. $\mathrm{O}$ autor indica algumas ações que levam ao desenvolvimento sustentável:

$>$ fechamento do ciclo da cadeia produtiva de materiais, produtos e resíduos, controlando suas emissões ambientais;

$>$ economia de energia, com aumento da eficiência e desenvolvimento de fontes mais duráveis;

$>$ aumento da durabilidade;

$>$ promoção da qualidade dos produtos, dos processos de produção, dos materiais naturais e dos resíduos, utilizando-os largamente no ciclo econômico.

O desenvolvimento sustentável consiste num processo que leva a mudanças na exploração de recursos, na direção dos investimentos, na orientação do desenvolvimento tecnológico e nas mudanças institucionais, todas visando à harmonia e ao entrelaçamento nas aspirações e necessidades humanas presentes e futuras. Este conceito não implica somente multidisciplinariedade, envolve também mudanças culturais, educação ambiental e visão sistêmica (BRANDON, 1998; ANGULO, 1999; JOHN, 2000).

Atualmente, o modelo de produção da construção civil é linear; seguindo a lógica de projeto, construção, utilização e geração de resíduos. Os grandes problemas que este sistema apresenta são (JOHN, 1999):

$>$ matérias primas cada vez menos abundantes, com dificuldades de obtenção e custos crescentes;

$>$ gerenciamento caro e oneroso de resíduos, em virtude dos grandes volumes acumulados pela sociedade de consumo;

$>$ grande consumo de energia.

Para o desenvolvimento sustentável é necessário um novo modelo de produção, em que se otimize o uso de recursos e a geração de resíduos seja minimizada. O modelo 
apresentado na Figura 1.2 aproxima-se do conceito de desenvolvimento sustentável, em que a reciclagem de resíduos torna-se fundamental (JOHN, 1999).

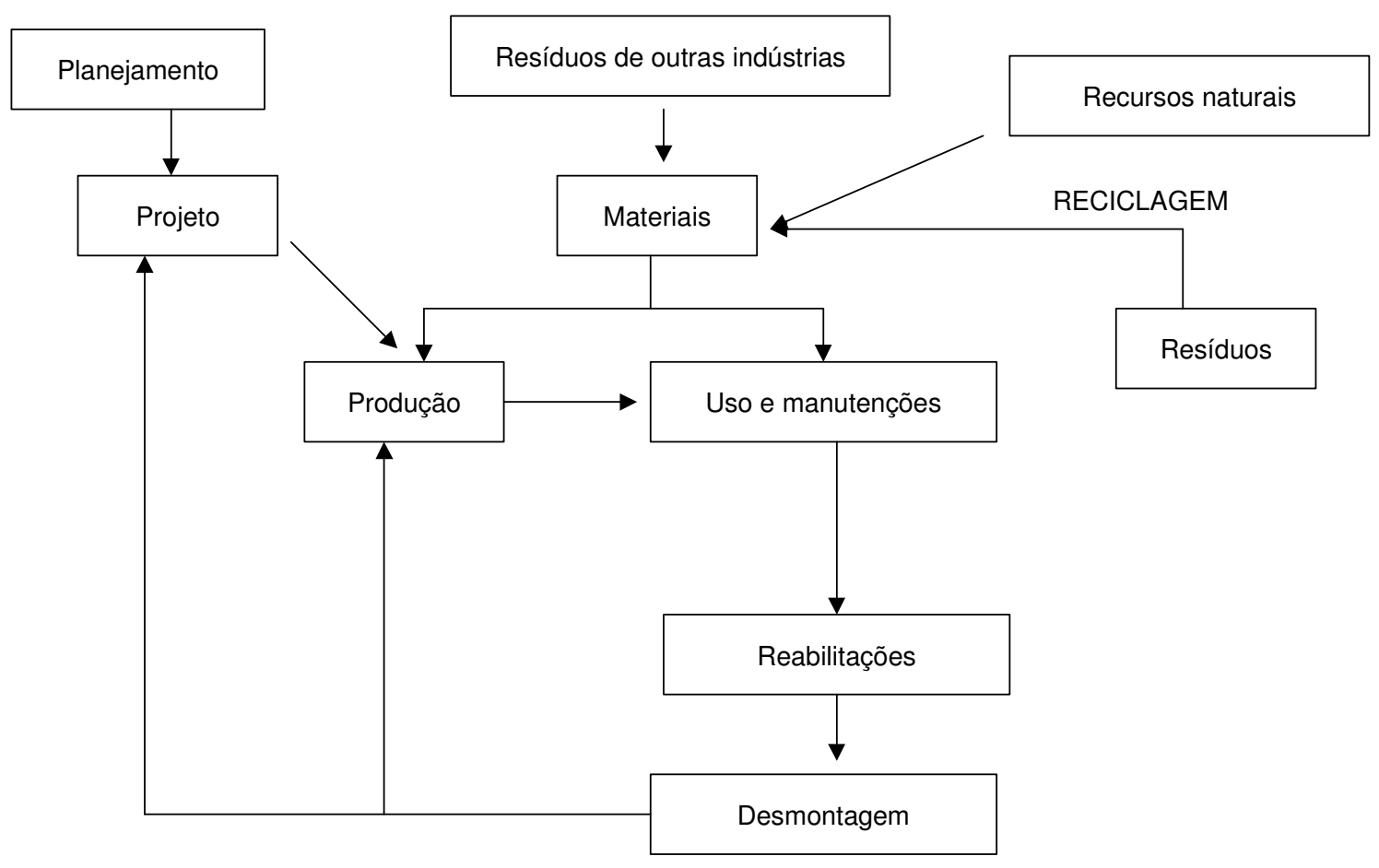

Figura 1.2 - Ciclo de produção fechado para a construção (CURWELL; COOPER, 1998 modificado apud JOHN, 1999).

Nos conceitos de desenvolvimento sustentável, a minimização da geração de resíduos é foco principal (GAVILAN; BERNOLD, 1994; BOSSINK; BROUWERS, 1996). A estratégia de minimização de resíduos teve origem nos Estados Unidos pela USEPA (United States Environmental Protection Agency). As modalidades de gestão atual devem incluir uma visão sistêmica, propondo a redução da geração de resíduos, do consumo e do desperdício, com papel fundamental para a educação ambiental, criando a consciência dos cidadãos quanto a variável ambiental (GUNTHER, 2000).

A redução do desperdício pode ser contemplada nas estratégias de aumento de produtividade e qualidade na construção civil. Essa redução contribui para a menor geração de resíduos e utilização dos recursos naturais. Muitos trabalhos têm desenvolvido o tema, como os de PICCHI (1993), SOUZA et al. (1999) e ANDRADE (1999).

As políticas ambientais não se limitam a ações de prevenção na geração de resíduos, englobando também avaliação de impacto ambiental de produtos, reciclagem 
de resíduos, melhoria da qualidade de produtos e projetos voltados para sustentabilidade.

De um modo geral, as políticas atuam em três diferentes áreas (BOSSINK; BROUWERS, 1996; SCHULTMANN et al., 1997; ZWAN, 1997; WILBURN; GOONAN, 1998):

$>$ política de resíduos, atuando prioritariamente com prevenção, reciclagem, incineração e aterro, sendo o governo gerador de condições para que o livre mercado absorva os resíduos;

$>$ política de proteção ao solo, criando pré-condições para se aterrar materiais residuais, segundo critérios higiênicos e ambientais;

> política de superfície mineral, controlando a cadeia produtiva de recursos naturais, visando a prevenção da degradação e limitando a produção.

Uma das formas de se atuar na política de resíduos, prevenindo a sua geração, é a criação de sistemas de certificação ambiental, LEED nos Estados Unidos e BREEAM na Inglaterra. Com essas ferramentas pode-se avaliar o impacto ambiental de edifícios comerciais e criar decisões voltadas para o menor risco ambiental e sustentabilidade, antes mesmo da própria execução dos edifícios (YATES; HAMPTON, 1997; JOHN,1999).

A ferramenta básica para avaliação de impacto ambiental é a análise do ciclo de vida (ACV no Brasil e LCA em inglês). Ela pode ser definida como: "processo que avalia ambientalmente produtos, processos e atividades, identificando e quantificando energia, materiais utilizados e resíduos do berço ao túmulo...” (SCHUURMANSSTEHMANN, 1994; TUKKER; GIELEN, 1994; BARTON et al., 1996).

A análise do ciclo de vida compreende, além do impacto ambiental do resíduo, todas as fases de vida do produto. Utiliza-se do "berço ao túmulo" como a expressão de avaliação do impacto (SCHUURMANS-STEHMANN, 1994).

Cada aspecto ambiental levantado pela ferramenta possui uma medida padrão, possuindo um quantitativo em determinado aspecto específico. Esta avaliação permite uma quantificação em termos financeiros do impacto ambiental, conforme sugerem economistas ambientais (SCHUURMANS-STEHMANN, 1994; BARTON et al., 1996).

Ações para a política de resíduos podem também ser direcionadas para a reciclagem, como é o caso da Alemanha que exige planos de demolição seletiva, 
método de demolição e detalhamento de informações para a reciclagem, na retirada do alvará de demolição (RUCH et al., 1997).

No Brasil, a legislação é ainda incipiente. As leis orgânicas municipais estipulam como responsabilidade dos municípios, estado e federação a proteção ao meio ambiente e combate à poluição em todas as formas (PINTO, 1999).

A resolução do CONAMA, número 237 de 19/12/1997, sugere que as atividades de tratamento e disposição final de resíduos sólidos devem estar sujeitas ao licenciamento ambiental do órgão competente (PINTO, 1999; JOHN, 1999).

Em âmbito federal, foi criado um grupo de trabalho com objetivo de elaborar o Programa Brasileiro de Reciclagem, visando ao desenvolvimento do parque industrial nacional de reciclagem (JOHN, 1999).

Recentemente, o governo do estado de São Paulo iniciou a discussão de uma Política Estadual de Resíduos Sólidos, mas sua atuação é mais punitiva do que educadora. Em contraponto com as políticas punitivas, o mesmo governo, através da CETESB, criou as câmaras ambientais. A construção civil participa com um grupo de trabalho. (JOHN, 1999).

Não existe uma política nacional ou estadual que direcione municípios para gerenciar seus RCD, com um sistema de coleta bem definido. PINTO (1999) propõe um sistema de gestão baseado na máxima captação dos RCD gerados, na reciclagem dos resíduos captados e na alteração de procedimentos e culturas. Visa a uma integração de agentes (geradores e coletores, público e privado).

Por esse sistema de gestão de PINTO (1999), criam-se áreas para a recepção de pequenos volumes com aproximadamente $300 \mathrm{~m}^{2}$. Existem também áreas de atração de médio porte, com 3.000 a $5.000 \mathrm{~m}^{2}$. Definem-se bacias de captação de resíduos para toda zona urbana geradora.

Ainda, um sistema de recepção de cargas homogêneas foi concebido, evitando a miscigenação dos resíduos sólidos. Há um processo de reciclagem dos RCD e que permite novas formas de destinação para outros tipos de resíduos. Nesta gestão, destacou-se a necessidade de ação indutora do poder público para atrair investimentos privados, de substituir os investimentos públicos e de canalizar a produção dos produtos para a própria atividade construtiva geradora dos resíduos (PINTO, 1999).

A Tabela 1.9 compara os preços de uma gestão diferenciada de PINTO (1999) e os de uma gestão convencional. 
Tabela 1.9 - Despesas totais de algumas municipalidades com gestões (PINTO, 1999).

\begin{tabular}{|c|c|}
\hline Despesas com gestão corretiva & Despesas com gestão diferenciada \\
\hline $\mathrm{R} \$ 124.501$ & $\mathrm{R} \$ 72.290$ \\
\hline
\end{tabular}

Fonte: dados obtidos nos municípios de Santo André, São José do Rio Preto e Jundiaí. 


\section{RECICLAGEM DOS RCD COMO AGREGADOS}

Dentre as estratégias de políticas públicas que visam ao desenvolvimento sustentável está a reciclagem dos RCD, como uma forma de solução para os problemas gerados por esses resíduos. As frações metálicas podem ser recicladas como metais, enquanto plásticos também podem ser reciclados como plásticos. A fração inorgânica não-metálica pode ser reciclada como agregados. Para este trabalho, só será discutida a reciclagem de RCD como agregados.

Definem-se agregados de RCD reciclados homogêneos os oriundos da reciclagem dos $\mathrm{RCD}$, porém com a presença de uma única fase inorgânica não-metálica dominante. São pertencentes a essa definição os agregados reciclados de concreto (contendo somente concreto) e os agregados reciclados de cerâmica (contendo somente materiais cerâmicos).

São ainda considerados agregados reciclados de RCD mistos os agregados provenientes também da reciclagem dos $\mathrm{RCD}$, porém com diversas fases presentes, tais como argamassa, cerâmica, cerâmica polida, materiais betuminosos, concreto, rochas, madeira, metais, plásticos, amianto, solo e cal, com predominância, no entanto, de fases inorgânicas não-metálicas.

Convém destacar que nem sempre a reciclagem é uma solução que garante a inexistência de impacto ambiental. A reciclagem de RCD também impacta o ambiente, principalmente em atividades de transporte, reprocessamento e resíduos.

No estudo de caso realizado por SCHUURMANS-STEHMANN (1994), a substituição de $40 \%$ de agregados graúdos reciclados de concreto pelos agregados naturais na produção de concreto causou pouca diferença no impacto ambiental total avaliado pela ferramenta LCA, quando comparado ao concreto utilizando recursos naturais.

\subsection{PROCESSO DE PRODUÇÃO DOS AGREGADOS DE RCD RECICLADOS}

O processo de produção de agregados de RCD reciclados depende basicamente da viabilidade técnica e econômica. 
Os resíduos são compostos de diferentes materiais. Portanto, é indispensável que o processo seja capaz de realizar a separação da fração reciclável como agregado da que deve ter outra destinação.

No Brasil, as plantas de reciclagem de RCD só possuem sistemas de britagem e peneiramento, sendo voltadas para a parcela inorgânica não-metálica desses resíduos. Na Figura 2.1 observa-se uma planta típica para processamento de RCD, nos Estados Unidos, em que existe reciclagem de outras parcelas dos resíduos, como metais, madeiras, etc.

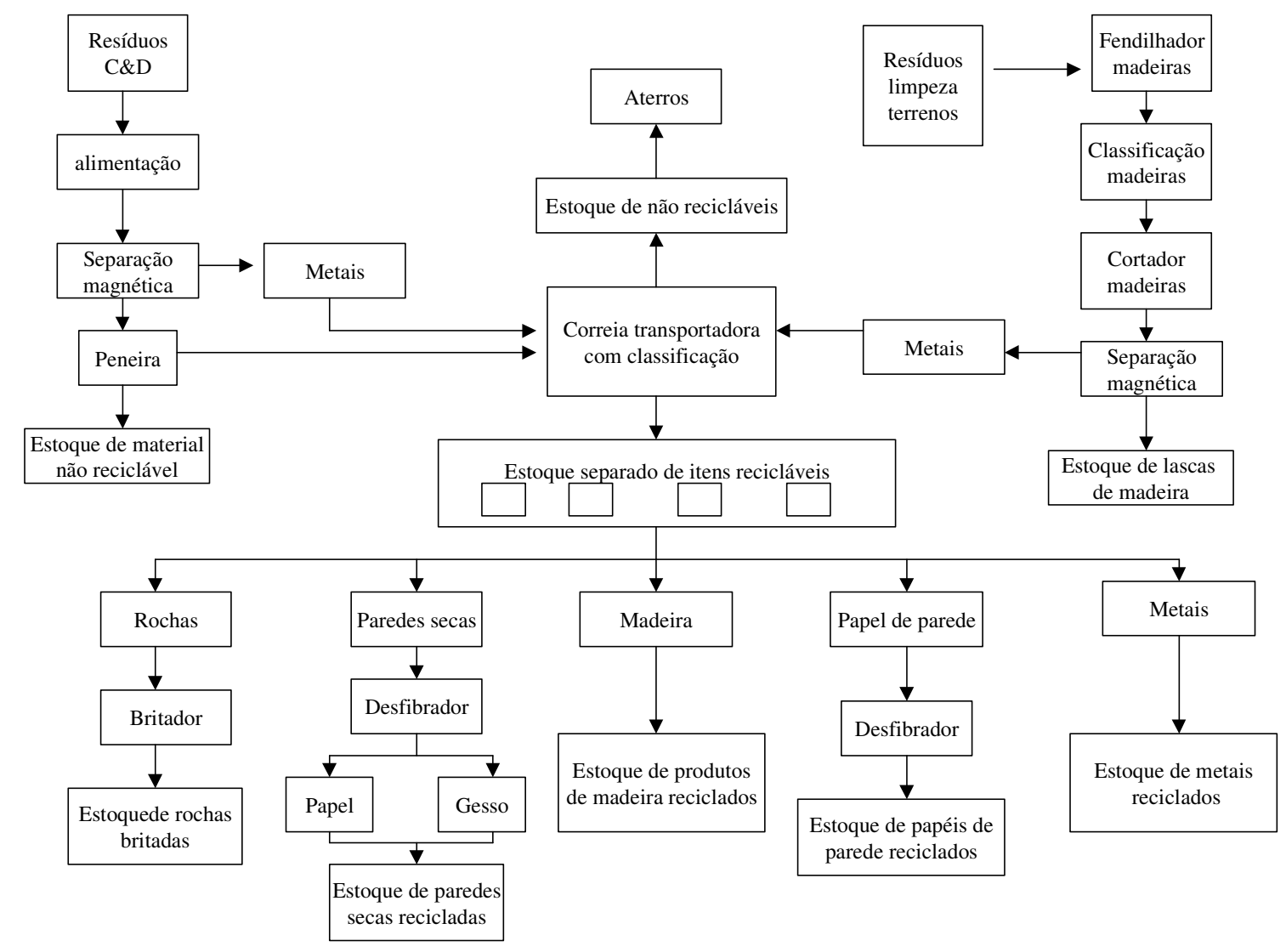

Figura 2.1 - Planta de reciclagem de RCD (PENG et al., 1997).

As atividades de britagem, peneiramento e lavagem são uma forma de se reciclar a fração inorgânica não-metálica dos $\mathrm{RCD}$, sendo a reciclagem como um todo algo bem mais complexo, inclusive com a necessidade de outros equipamentos.

Na reciclagem da fração mineral dos RCD, deve-se levar em conta a presença de materiais indesejados, como materiais ferrosos, plásticos, madeiras, quando não se utilizam equipamentos de separação e classificação, como os expostos (PENG et al.,1997; QUEBAUD; BUYLE-BODIN, 1999): 
> separador magnético, utilizado para remover materiais ferrosos pela força eletromagnética;

tanques de depuração por flutuação, separando pela densidade madeiras e plásticos;

$>$ classificador por ar, separando densidades diferentes pelo escoamento de ar horizontal e vertical.

Os RCD devem passar por seleção rigorosa e serem estocados segundo qualidade e facilidade de tratamento. Em seguida, devem ser quebrados até atingirem dimensões compatíveis com a entrada dos britadores. Controles do teor de sulfatos, oriundos do gesso, devem ser realizados em diferentes estágios da britagem dos agregados, em razão dos componentes do gesso. (QUEBAUD; BUYLE-BODIN, 1999).

A Figura 2.2 mostra um fluxograma de uma planta de reciclagem, gerando agregados de RCD reciclados pelo processo de britagem. Os processos de britagem primária e secundária podem ser necessários, dependendo do tipo de equipamento utilizado na Central. A geração de maior ou menor quantidade dos tipos de frações pode alterar potenciais aplicações, pois elevada quantidade de agregados miúdos favorece a utilização para argamassas e blocos, enquanto alta quantidade de agregados graúdos favorece o emprego em concretos. 


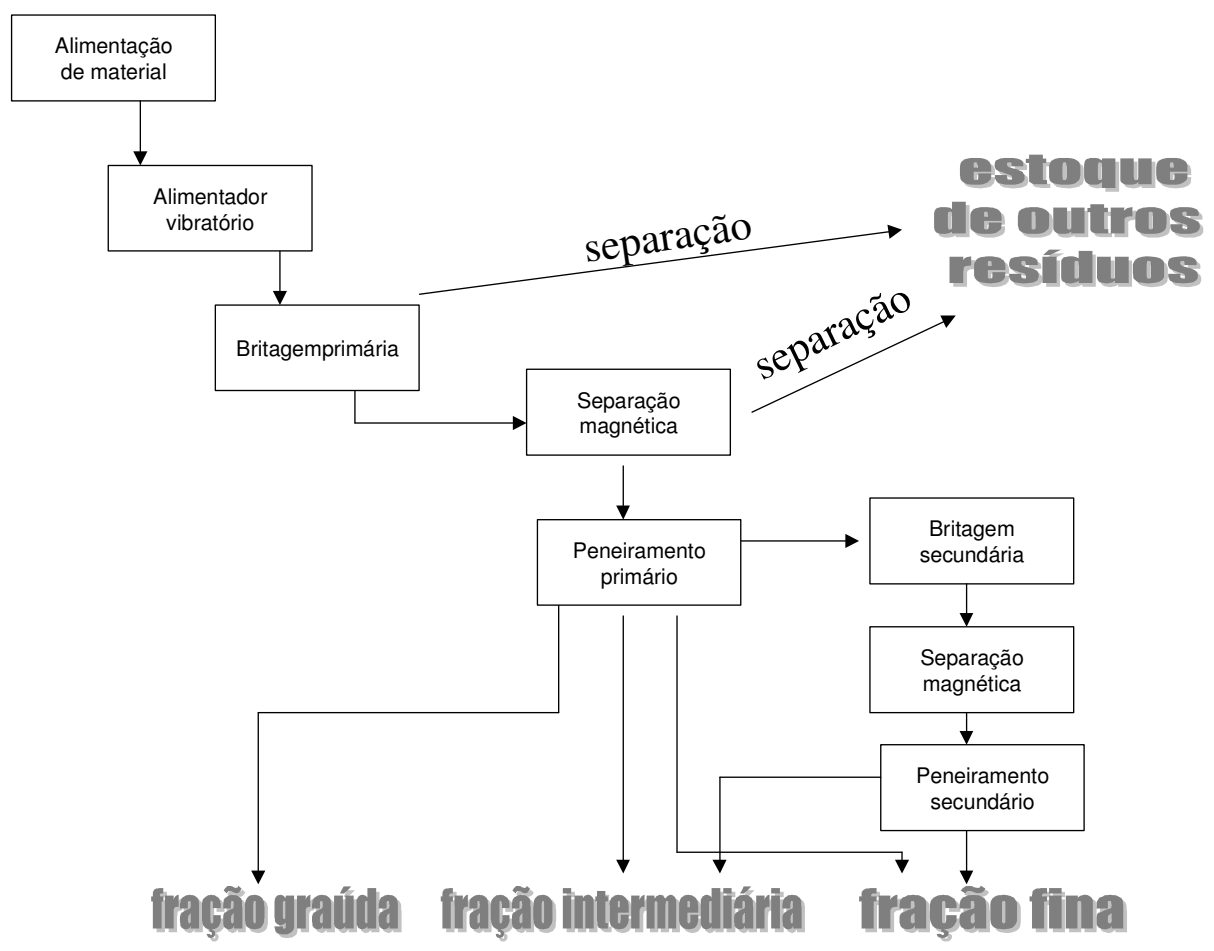

Figura 2.2 - Fluxograma de uma planta de reciclagem de produção dos agregados de RCD reciclados (WILBURN; GOONAN, 1998 modificado).

No Brasil, as plantas de reciclagem de RCD se limitam ao tipo exposto na Figura 2.2, não havendo nenhum outro tipo de equipamento para a separação, como tanques de flutuação e separadores por injeção de ar. A maior parte nem chega a apresentar a etapa de britagem secundária.

O mesmo ocorre em outros países. WASTE AGE (1992) apud ZORDAN (1997) aponta que a maioria das centrais de moagem não possui flotadores de ar, separadores magnéticos e a ar.

A Tabela 2.1 mostra os principais tipos de equipamentos de britagem utilizados na reciclagem de $R C D$.

Tabela 2.1 - Equipamentos de britagem utilizados na reciclagem de RCD (PENG et al., 1997 modificado; LEVY, 1997a).

\begin{tabular}{|l|l|}
\hline Britador & Propósito \\
\hline De Impacto & $\begin{array}{l}\text { Possui unidades primárias e secundárias. Fornece agregados com } \\
\text { granulometria boa para obras rodoviárias. Pouco sensíveis à presença de } \\
\text { barras de aço. }\end{array}$ \\
\hline De Mandíbula & $\begin{array}{l}\text { Especialmente desenvolvido para britar rochas e materiais similares Produz } \\
\text { bons agregados para concretos estruturais. }\end{array}$ \\
\hline De Martelo & $\begin{array}{l}\text { Reduz pelo impacto partículas maiores em partículas menores. Produz } \\
\text { material de granulometria fina. }\end{array}$ \\
\hline De Rolos & $\begin{array}{l}\text { Reduz a diâmetros de 7,5 a 10,0 cm. No caso do equipamento marca ANVI, } \\
\text { pode-se utilizá-lo como betoneira também. }\end{array}$ \\
\hline
\end{tabular}


Os britadores de impacto geram maiores quantidades de agregados miúdos, enquanto que os britadores de mandíbula apresentam menores quantidades de agregados miúdos. O fator de redução é 10:1 (miúdos:graúdos) para britadores de impacto e na proporção 4:1 para britadores de mandíbula² no Brasil.

Os autores identificam que a absorção de água do agregado - problemática na produção de concreto - cresce com a quantidade de argamassa aderida aos agregados naturais (medida por dissolução no ácido clorídrico), conforme a Figura 2.3. Este parâmetro deve ser considerado na decisão do tipo de equipamento de britagem a ser utilizado.

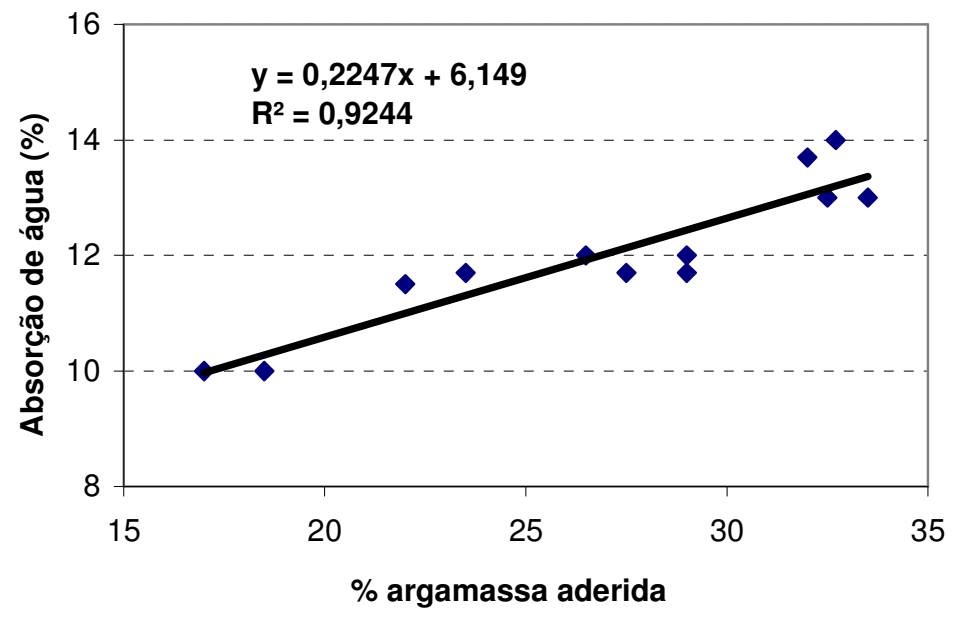

Figura 2.3 - Correlação entre quantidade de argamassa aderida aos grãos e a absorção de água agregados miúdos reciclados de concreto (QUEBAUD-BUYLE-BODIN, 1999).

Os valores de absorção de água de agregados miúdos reciclados são maiores que os de agregados graúdos reciclados, e a abertura da mandíbula dos britadores pode aumentar a quantidade de material passante na peneira $\# 4,8 \mathrm{~mm}$, variando de 7 a $14 \%$ em relação ao percentual total. A resistência à compressão do concreto processado também influi no valor de absorção de água dos agregados reciclados de concreto (B.S.C.J,1977 apud LEVY, 1997a; RAVINDRARAJAH; TAM (1985) apud LEVY, 1997a).

${ }^{2}$ Informações dadas pelo Dr. Tarcísio de Paula Pinto, durante a realização do Exame de qualificação desta dissertação, na Escola Politécnica da Universidade de São Paulo. 
Quanto menor a capacidade operacional do equipamento, menores são os diâmetros admissíveis dos fragmentos na alimentação. Britadores de impacto possuem uma capacidade de redução de partículas superior aos britadores de mandíbula, sendo pouco sensíveis à presença de resíduos de madeira e metálicos. Os britadores de mandíbula são mais sensíveis e eficientes para agregados reciclados de concreto, quando possuem sistema de britagem secundária (PINTO, 1999).

Agregados de RCD reciclados possuem características tecnológicas diferentes de agregados naturais, conforme observa-se na Tabela 2.2.

Tabela 2.2 - Aspectos tecnológicos relevantes de agregados de RCD reciclados e naturais (WILBURN; GOONAN, 1998, modificado).

\begin{tabular}{|l|l|}
\hline Agregados naturais & Agregados de RCD reciclados \\
\hline $\begin{array}{l}\text { Qualidade depende de propriedades físicas } \\
\text { e químicas do depósito. }\end{array}$ & $\begin{array}{l}\text { Qualidade varia muito e depende da fonte } \\
\text { e impurezas. }\end{array}$ \\
\hline Fonte única e centralizada. & Fonte variada e dispersa na malha urbana. \\
\hline Situado em áreas fora da cidade. & Situado em áreas urbanas. \\
\hline Localização depende mais da fonte. & Localização depende da fonte e mercado. \\
\hline
\end{tabular}

É difícil a incorporação da britagem de resíduos minerais de construção e demolição por usinas de agregados naturais, pois exige um sistema de controle de qualidade diferenciado, considerando-se a variabilidade e contaminação dos agregados de RCD reciclados, além de exigir equipamentos complementares como separador magnético. Além disso, as pedreiras encontram-se normalmente afastadas dos centros urbanos, implicando grandes distâncias de transporte.

É indispensável, para o sucesso econômico da reciclagem, minimizar a distância entre o reciclador, fornecedor de resíduos e o mercado consumidor (WILBURN; GOONAN, 1998). A Figura 2.4 mostra exemplos de localizações de centrais de reciclagem de entulho. Observa-se que a planta $\mathrm{C}$ opera com as menores distâncias de transporte, sendo bem mais competitiva que as outras. 


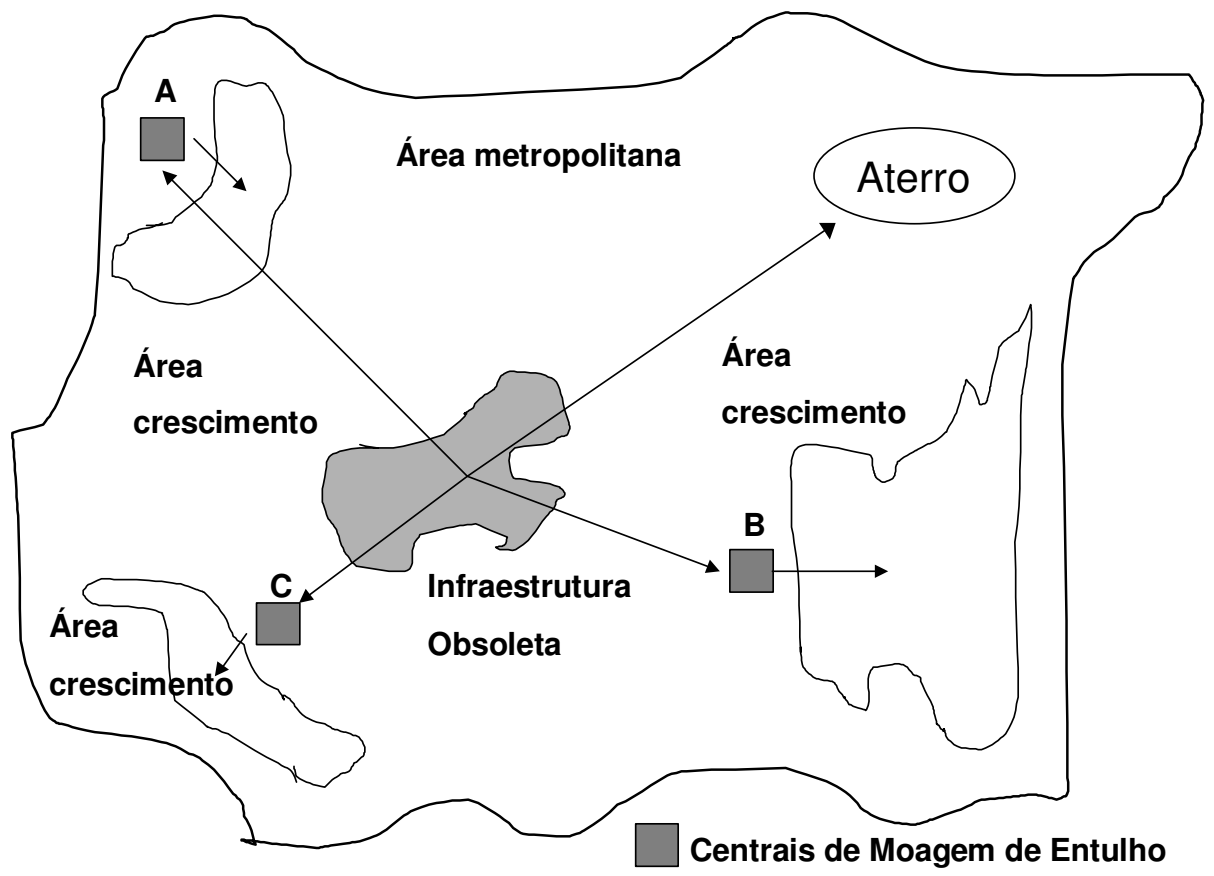

Figura 2.4 - Localizações de centrais de moagem de entulho (WILBURN;

GOONAN, 1998).

A reciclagem de RCD parece ser um novo e promissor empreendimento, sendo vital considerar alguns fatores como venda do produto, forma da planta e seu porte, qualidade do material a ser reciclado, energia consumida, custos de aterros locais, regulamentações ambientais, qualificação de funcionários, etc.

Além disso, todo produto tem um ciclo de vida, passando por diferentes fases de desenvolvimento no que diz respeito ao mercado. Atualmente, resíduos são produtos sem apreciação, devendo passar por etapas de desenvolvimento e crescimento, até atingir uma maturidade de mercado. Como a geração de resíduos não pode ser controlada, pois a disponibilidade de "matéria-prima" é inelástica, não se pode ampliar ou reduzir a sua produção, quando se visam às relações com o mercado. Aumentos na oferta de matéria-prima podem causar quedas de preços (ZWAN, 1997; VRIJLING, 1991).

\subsection{PRESENÇA DE CONTAMINAÇÕES E MATERIAIS INDESEJÁVEIS}

A seguir, serão apresentados alguns tipos de contaminantes que podem estar presentes nas construções, gerando possíveis danos ao ambiente durante a estocagem e emprego do agregado reciclado, conforme observa-se na Tabela 2.3. 
Tabela 2.3 - Fontes de poluentes potenciais em construções.

\begin{tabular}{|l|l|}
\hline Origens & Poluentes relevantes \\
\hline Pedra natural & Metais pesados. \\
\hline Concreto/argamassa & Cromo, molibdênio. \\
\hline Gesso & Sulfatos, metais pesados. \\
\hline Relacionadas ao uso & Óleos, álcalis, ácidos. \\
\hline Plásticos & Fenóis, hidrocarbonetos, comp. orgânicos \\
\hline Madeira tratada & Metais pesados e fenóis. \\
\hline \multicolumn{2}{|c|}{ Fonte: SCHULTMANN et al.,1997; WAHLSTROM et al.,1996. } \\
\hline \multicolumn{2}{|c|}{}
\end{tabular}

Em um estudo de caso observou-se a presença de contaminantes em agregados reciclados provenientes de resíduos de demolição, em que poluentes encontravam-se em maior quantidade nas frações finas dos agregados (SCHULTMANN et al., 1997).

Quanto à presença de sulfato em agregados de $\mathrm{RCD}$ reciclados, teores de $0,3 \mathrm{a}$ $0,8 \%$ de sulfato (em massa) não produzem efeitos significativos na resistência mecânica e na expansão, porque grande parte dos sulfatos vem dos cimentos hidratados na matéria-prima (GALLIAS, 1998). São as impurezas do gesso que, em percentuais superiores a $1 \%$ da massa, causam expansão significativa em argamassas (GALLIAS, 1998).

Para o mesmo autor, o teor de sulfato pode chegar até 1,2\% (em massa) nos agregados de RCD reciclados para ocorrer expansão crítica. Quando o cimento tem pouco $\mathrm{C}_{3} \mathrm{~A}$, este valor limitante pode ser excedido. As expansões e quedas da resistência à compressão são mais significativas quando aplicados agregados finos reciclados.

Em um estudo de caso, as contaminações de compostos orgânicos em demolições tradicionais foram consideradas excessivas para utilização. Nas técnicas de demolição seletiva, essas contaminações ficam próximas a valores limites, conforme observado na Figura 2.5 (SCHULTMANN et al., 1997). 


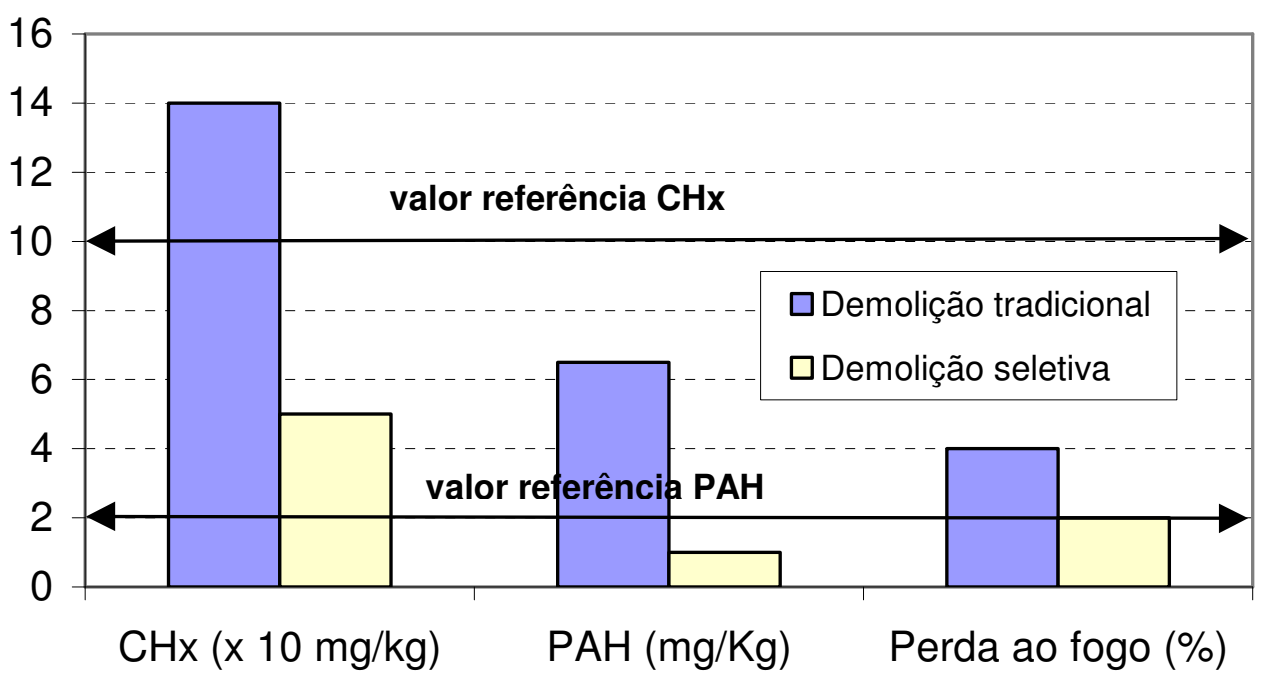

$\mathrm{CH}_{\mathrm{x}}$ - hidrocarbonetos e $\mathrm{PAH}$ - hidrocarbonetos aromático policíclico

Figura 2.5 - Presença de componentes orgânicos em função das técnicas de reciclagem (SCHULTMANN et al., 1997).

B.S.C.J. (1977) apud HANSEN (1992) apresenta alguns percentuais (em volume) de materiais indesejáveis que podem reduzir em até $30 \%$ a resistência à compressão de concretos com agregados reciclados de concreto. São eles materiais betuminosos, solos, madeira, gesso, asfalto e tinta PVA nas seguintes porcentagens respectivamente: $30 \%, 5 \%, 4 \%, 3 \%, 2 \%$ e $0,2 \%$.

Os metais podem causar danos na superfície dos componentes por causa da oxidação (LEVY, 1997a). HANSEN (1992) afirma que este efeito pode potencializar-se na presença de cloretos. Zinco e alumínio podem causar expansões internas nos componentes. O teor de matéria orgânica deve ser inferior a $0,15 \%$ da massa do agregado (B.C.S.J., 1977 apud HANSEN, 1992).

Existe a possibilidade de reação álcali-agregado. Nessas reações influenciam o tamanho das partículas de vidro, o tipo de vidro, a coloração e o seu percentual presente no concreto. Vidros claros são os mais reativos, sendo a reatividade inversamente proporcional à densidade do vidro. As expansões são linearmente proporcionais à quantidade de vidro na pasta, sendo as partículas entre 4 e $16 \mathrm{~mm}$ as mais expansivas (MEYER et al., 1997; HANSEN, 1992). 


\subsection{UTILIZACÃO DOS AGREGADOS DE RCD RECICLADOS}

\subsubsection{Em concretos plásticos}

Para uma mesma resistência à compressão de concretos plásticos é necessário aumentar o consumo de cimento dos concretos com agregados de RCD reciclados. Este efeito potencializa-se com o aumento do emprego de partículas finas. As partículas finas demandam uma maior quantidade de água, devido à alta capacidade de absorção (LEVY, 1997a; ZORDAN, 1997; DESSY et al., 1998).

Para agregados de concreto reciclados, a resistência do concreto que gerou o agregado reciclado será o fator limitante do concreto reciclado, quando avaliado no requisito de resistência à compressão. Nos agregados com resistências inferiores à da pasta, eles são o fator limitante. Nos agregados com resistência superior à da pasta, a pasta é limitante, não influenciando a resistência do agregado (TAKAVOLI; SOROUSHIAN, 1996 apud LEVY, 1997a; ANGULO, 1998).

Efeito semelhante pode ser observado em trabalho realizado por ZORDAN et al. (1999), conforme observado na Figura 2.6, a seguir. Para este caso, as consistências dos concretos foram mantidas constantes, sendo necessárias altas relações água/cimento para os baixos consumos de cimento.

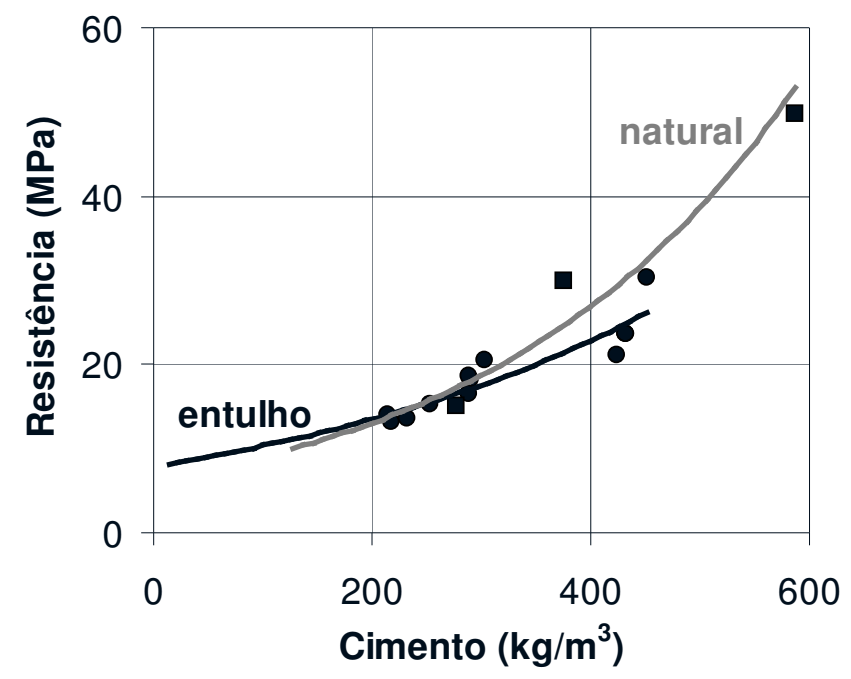

Figura 2.6 - Consumo de cimento $\mathrm{x}$ resistência para concretos reciclados e naturais (ZORDAN et al., 1999).

Para altas relações água/cimento, a pasta torna-se o ponto fraco do concreto. Com isto, a influência da resistência e a composição do agregado passam a ter efeito 
mais significativo após $300 \mathrm{Kg}$ de cimento $/ \mathrm{m}^{3}$ de concreto, quando a resistência da pasta fica superior à resistência dos agregados.

RASHEEDUZZAFAR; KHAN (1984) apud LEVY (1997a) também observaram pouca influência dos agregados reciclados na resistência do concreto em altas relações água/cimento, quando comparados com concretos de agregados naturais.

Identificaram-se rupturas nos agregados reciclados, quando avaliados quanto à resistência à compressão, especificamente na argamassa contida nos agregados reciclados de concreto (YANNAS, 1997 apud ZORDAN, 1997).

BARRA (1997) conclui que, no estado fresco de concretos reciclados, a água fica na superfície dos agregados de RCD não saturados devido ao processo de absorção. Quando adicionado cimento, grande quantidade das partículas do cimento ficam retidas nos grãos, favorecendo a aderência pasta-agregado.

Provavelmente em virtude do mesmo processo de aderência pasta-agregado, concretos utilizando agregados reciclados de concreto melhoraram a interface pastaagregado, obtendo resistências à compressão dos concretos quase no valor de duas vezes a resistência dos agregados, quando os agregados não estavam pré-saturados em água. Para este caso, a resistência dos agregados deveria ser o fator limitante da resistência dos concretos reciclados (ANGULO, 1998).

Com relações água/cimento muito baixas, a não correção da absorção de água dos agregados de RCD pode retirar a água necessária à hidratação, mas não se sabe ao certo qual a parcela que é absorvida e qual é a hidratada num estado fresco determinado.

BARRA (1996) afirma que os processos de produção influem na qualidade da zona de transição entre a pasta nova e o agregado reciclado e, conseqüentemente, na durabilidade dos concretos.

GALLIAS (1998) considera que, quando os agregados de RCD reciclados são pré-saturados antes da aplicação, a água absorvida não participa da trabalhabilidade nem das reações de hidratação do cimento.

As resistências à tração e à flexão dos concretos reciclados ficaram $10 \%$ inferiores às dos concretos convencionais. Quanto ao módulo de elasticidade, os valores são inferiores aos dos concretos convencionais (LEVY, 1997a).

Um dos grandes problemas dos concretos reciclados é a retração que, em razão da absorção de água dos agregados de RCD, mantém maior quantidade de pasta e um volume maior de água capaz de evaporar (QUEBAUD-BUYLE-BODIN,1999). 
HANSEN; BOEGH (1983) apud ZORDAN (1997) falam em valores de 40 a $60 \%$ maiores que em concretos convencionais.

A permeabilidade dos concretos com agregados de RCD reciclados também é problemática, chegando a ser de 2 a 5 vezes maior que em concretos convencionais (B.S.C.J., 1977 apud HANSEN, 1992).

Em relação à durabilidade, fatores como velocidade de carbonatação e ingresso de cloretos em concretos com agregados de RCD reciclados são diferentes, graças a possíveis carbonatações e presença de cloretos nos concretos de origem. Assim, a durabilidade de concretos reciclados pode ser inferior à de concretos convencionais (RILEM RECOMMENDATION, 1994).

\subsubsection{Em argamassas}

O consumo de cimento se reduz ou se mantém constante quando são produzidas argamassas com agregados de RCD reciclados (LEVY, 1997a). Quanto à retenção de água, LEVY (1997a) indica a redução de $15 \%$.

Produziram-se argamassas com resistências à compressão e tração superiores às argamassas convencionais, o que pode ter acontecido pela presença de atividade pozolânica nos entulhos utilizados por LEVY (1997a) ou pela não correção de água da argamassa devido a absorção pelo RCD, já que MIRANDA (2000) mostrou que a resistência mecânica das argamassas com RCD está muito bem correlacionada com a relação água/cimento corrigida.

Quanto ao custo da argamassa produzida com agregados de RCD reciclados, MIRANDA (2000) chegou ao valor de até $40 \%$ do custo do $\mathrm{m}^{3}$ da argamassa de cimento, cal e areia no traço 1:2:9, em volume úmido, quando toda a areia é substituída por $\mathrm{RCD}$ reciclado.

Ainda MIRANDA (2000) afirma que, em uma pesquisa de campo, as argamassas recicladas apresentaram boa aceitação por pedreiros quanto à plasticidade, à adesão inicial ao substrato e ao desempenamento. Além disso, é possível obter revestimentos de argamassas com RCD reciclado com bons desempenhos quanto a aderência ao substrato e ao surgimento de fissuras quando são utilizadas técnicas racionais de dosagem. 


\subsubsection{Considerações sobre o estado fresco de concretos e argamassas}

Para concretos e argamassas, quanto à capacidade de absorção de água dos agregados de RCD reciclados em estado fresco, parte da água empregada pode ser absorvida pelos agregados secos (BARRA, 1997).

A absorção de água dos agregados de RCD reciclados é um fator que deve ser considerado nos estudos de dosagem dos concretos. Existem dificuldades para se manter a trabalhabilidade constante de concretos com agregados reciclados, quando os agregados são empregados em estado seco. Diversos autores chegaram a conclusões semelhantes (RAVINDRARAJAH; BUCH, 1977 apud LEVY, 1997; MUKAI, 1978 apud LEVY, 1997; IVANYL, 1985 apud LEVY, 1997; MALHOTRHA, 1987 apud LEVY, 1997; KASHINO; TAKAHASHI, 1988 apud LEVY, 1997; NIRO, 1996 apud LEVY, 1997; QUEBAUD-BUYLE-BODIN, 1999; MORALES; ANGULO, 2000).

QUEBAUD-BUYLE-BODIN (1999) mostram a influência da presença de agregados miúdos reciclados de concreto na consistência de concretos frescos, conforme a Figura 2.7.

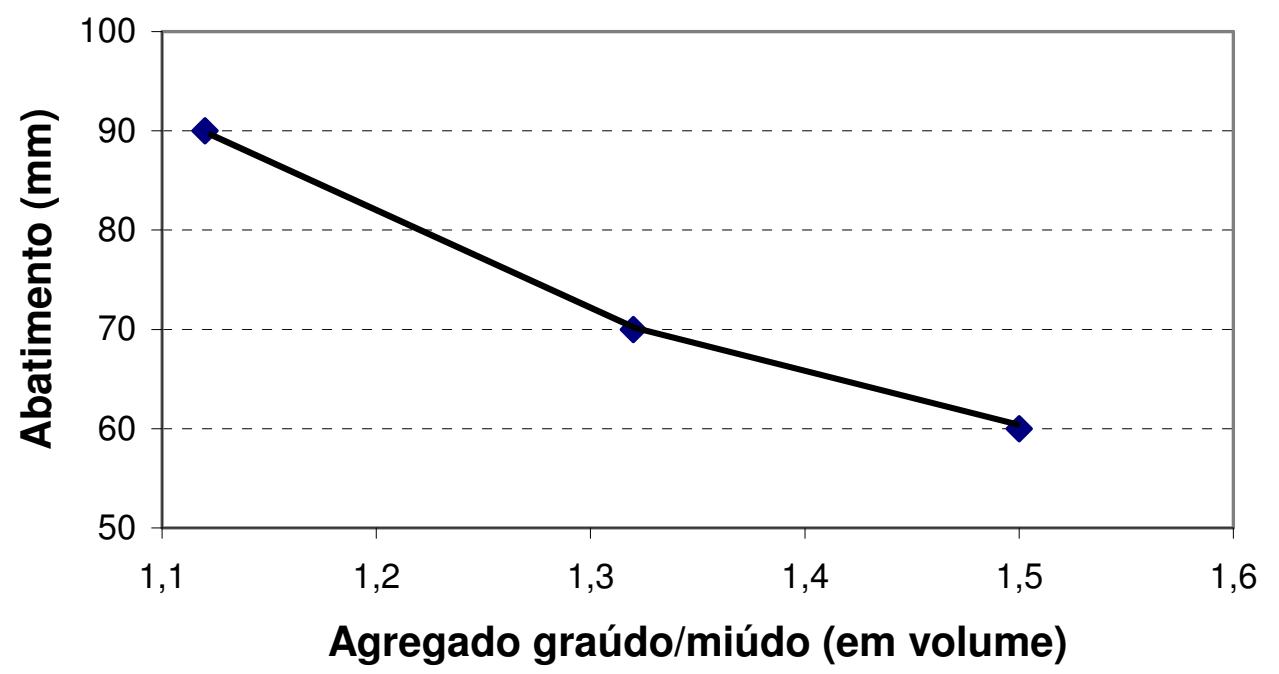

Figura 2.7 - Variação do abatimento em razão da adição de agregados miúdos reciclados de concreto (QUEBAUD-BUYLE-BODIN, 1999).

BARRA (1997) define um coeficiente de absorção efetivo, que seria a capacidade do agregado absorver a água no estado fresco do concreto, diferente da capacidade de absorção plena com total submersão dos agregados de RCD reciclados. 
Ajustes de traços no processo de produção devem levar em conta teor de umidade dos agregados, sequiência e tempo de mistura.

A autora levanta hipóteses sobre a absorção de água dos agregados no concreto fresco:

> O agregado absorve a água que está em contato, sendo portanto a relação água/cimento variável em função da proximidade da superfície do agregado.

> A quantidade de água absorvida depende da natureza do agregado e da consistência da pasta.

Nos agregados de RCD pré-saturados, não aparece um fluxo de água em direção ao interior dos grãos, entretanto há aumento de porosidade na zona de transição pasta-agregado, por causa da quantidade de água livre disponível na interface. Pode-se realizar um mecanismo de cura interna em tal procedimento, após o endurecimento do concreto (BARRA, 1997; ZORDAN, 1997).

\subsubsection{Em blocos de concreto}

DE PAUW (1982) estudou a substituição de agregados naturais por reciclados, na produção de blocos de vedação, com traço padrão de 1:8, porém sempre mantendo certa quantidade de areia natural. A Tabela 2.4 mostra o estudo de dosagem realizado, bem como a resistência à compressão média das séries.

Tabela 2.4 - Estudo de dosagem para determinação do traço e resistência à compressão média dos blocos produzidos com RCD.

\begin{tabular}{|c|c|c|c|c|c|c|}
\hline Série & \multicolumn{5}{|c|}{ Dosagem em massa } & \multirow{3}{*}{$\begin{array}{l}\text { Resistência } \\
\text { à compressão } \\
(\mathrm{MPa})\end{array}$} \\
\hline \multirow{2}{*}{$\begin{array}{c}\text { Traços } \\
\text { Utilizados }\end{array}$} & \multirow{2}{*}{$\begin{array}{l}\text { Cimento } \\
\text { P15-302 } \\
\text { (Kg) }\end{array}$} & \multirow{2}{*}{$\begin{array}{c}\begin{array}{c}\text { Areia } \\
\text { Natural } \\
(\mathrm{Kg})\end{array} \\
\text { grãos } \\
0-2 \mathrm{~mm} \\
\end{array}$} & \multirow{2}{*}{$\begin{array}{c}\text { Agregados } \\
\text { graúdos } \\
\text { naturais }(\mathrm{Kg}) \\
\text { grãos } \\
4-8 \mathrm{~mm}\end{array}$} & \multicolumn{2}{|c|}{ Material reciclado $(\mathrm{Kg})$} & \\
\hline & & & & $\begin{array}{c}\text { grãos } \\
0-25 m m\end{array}$ & $\begin{array}{c}\text { grãos } \\
3-12 \mathrm{~mm}\end{array}$ & \\
\hline referência & 50 & 100 & 300 & & & 3,7 \\
\hline 1 & 50 & 150 & & 250 & & 2,2 \\
\hline 2 & 50 & 100 & & 200 & & 3,3 \\
\hline 3 & 50 & 200 & & 200 & & 2,9 \\
\hline 4 & 50 & 150 & & & 300 & 4,1 \\
\hline 5 & 50 & 150 & & & 250 & $\overline{7,0}$ \\
\hline 6 & 50 & 200 & & & 200 & 2,1 \\
\hline aços util & os par & produ & ? ? & $10 \mathrm{x}$ & 190)mı & \\
\hline
\end{tabular}

Houve uma queda da resistência à compressão média, quando foi aplicado material reciclado da fração 0-25 $\mathrm{mm}$ em relação à fração 3-12 $\mathrm{mm}$. Isto pode ter 
ocorrido por causa do aumento da variabilidade na resistência à compressão provocado pela areia e finos ou, simplesmente, pela presença desses materiais ou efeitos da granulometria na compactação dos blocos.

A consistência foi em função da facilidade de aplicação da mão-de-obra local, não sendo informado um valor específico. Porém, em todos os casos, a resistência à compressão não foi um fator limitante a sua aplicação.

No Brasil, têm-se informações a respeito da construção de um alojamento utilizando blocos de RCD reciclado, nas dependências da Usina de Asfalto Municipal, no bairro da Barra Funda, entre os anos de 1992 e 1993. A EMURB (Empresa Municipal de Urbanização de São Paulo) também realizou estudos para implantar uma fábrica de blocos junto à usina de reciclagem de RCD de Itatinga (SP) (TOALDO, 1993).

COLLINS (1998) argumenta que a utilização de 75\% de agregados de RCD reciclados na produção de blocos foi possível sem nenhuma dificuldade, apresentando bom desempenho.

\subsection{VARIABILIDADE DOS AGREGADOS DE RCD RECICLADO}

\subsubsection{Variabilidade da composição}

A variabilidade dos agregados de $\mathrm{RCD}$ reciclados é diferente da variabilidade do RCD, pois as composições são diferentes antes e pós-processamento dos resíduos. Foi comprovado que frações cerâmicas, anteriormente retidas em sua maioria em frações de malha de $25 \mathrm{~mm}$, podem migrar em maior quantidade para as frações finas pós-britagem dependendo do equipamento (PINTO, 1986).

Ainda, considerando-se uma capacidade de redução constante de um determinado equipamento, as frações dos RCD retidas em diversas peneiras antes do processamento apresentaram composições diferentes, alterando a composição de agregados graúdos e miúdos reciclados, sem considerar a diferença de resistência das fases presentes que causaria uma maior ou menor capacidade de redução dos grãos (PINTO, 1986).

Desta forma, a composição antes da britagem não corresponde à composição pós-britagem. Além disso, a caracterização em agregados de RCD reciclados é mais 
prática, uma vez que as dimensões das partículas se encontram reduzidas, facilitando o manuseio.

Conforme mencionado no item 1.3.2 do primeiro capítulo, a variabilidade dos RCD ocorre principalmente em função de países, regiões de um mesmo país, das origens e do período de análise.

No Brasil, ZORDAN (1997) e PINTO (1986) avaliaram os possíveis tipos de variabilidade da composição no processo de produção dos agregados de RCD reciclados.

Na Tabela 2.5 mostra-se variabilidade de composição para agregados de RCD reciclados (ZORDAN, 1997) e a variabilidade dos RCD sem processamento (PINTO, 1986).

Tabela 2.5 - Variabilidade de $\mathrm{RCD}$ e agregados de $\mathrm{RCD}$ reciclados (\%, em massa).

\begin{tabular}{|c|c|c|c|c|c|c|}
\hline \multirow{2}{*}{ Fases } & \multicolumn{2}{|c|}{ Mínimo } & \multicolumn{2}{c|}{ Máximo } & \multicolumn{2}{c|}{ Média } \\
\cline { 2 - 7 } & $\begin{array}{c}\text { ZORDAN } \\
(1997) \\
\text { agregados }\end{array}$ & $\begin{array}{c}\text { PINTO } \\
(1986) \\
\text { RCD }\end{array}$ & $\begin{array}{c}\text { ZORDAN } \\
(1997) \\
\text { Agregados }\end{array}$ & $\begin{array}{c}\text { PINTO } \\
(1986) \\
\text { RCD }\end{array}$ & $\begin{array}{c}\text { ZORDAN } \\
(1997) \\
\text { Agregados }\end{array}$ & $\begin{array}{c}\text { PINTO } \\
(1986) \\
\text { RCD }\end{array}$ \\
\hline Concreto & 20 & 4,10 & 22 & 7,03 & 21 & 5,56 \\
\hline Argamassa & 35 & 41,44 & 39 & 79,16 & 37 & 60,30 \\
\hline Cerâmica & 15 & 12,73 & 26 & 47,69 & 20,50 & 30,21 \\
\hline Cerâmica polida & 1 & nd & 4 & nd & 2,50 & $\mathrm{Nd}$ \\
\hline Pedras & 10 & 0,76 & 27 & 2,04 & 18,50 & 1,40 \\
\hline Outros & 0 & 0,36 & 1 & 1,45 & 0,50 & 0,90 \\
\hline
\end{tabular}

Em outros países, têm-se concentrado esforços para trabalhar com agregados de RCD selecionados, especialmente agregados de concreto e de alvenaria, criando especificações que limitam as aplicações conforme aumenta a presença de outras fases (RILEM RECOMENDATION, 1994; HANSEN,1992).

Apresenta-se, na Figura 2.8, a variabilidade da composição, em função do período de coleta, obtida na Central de Moagem de Ribeirão Preto. As amostras foram coletadas com diferenças de um mês entre elas. 


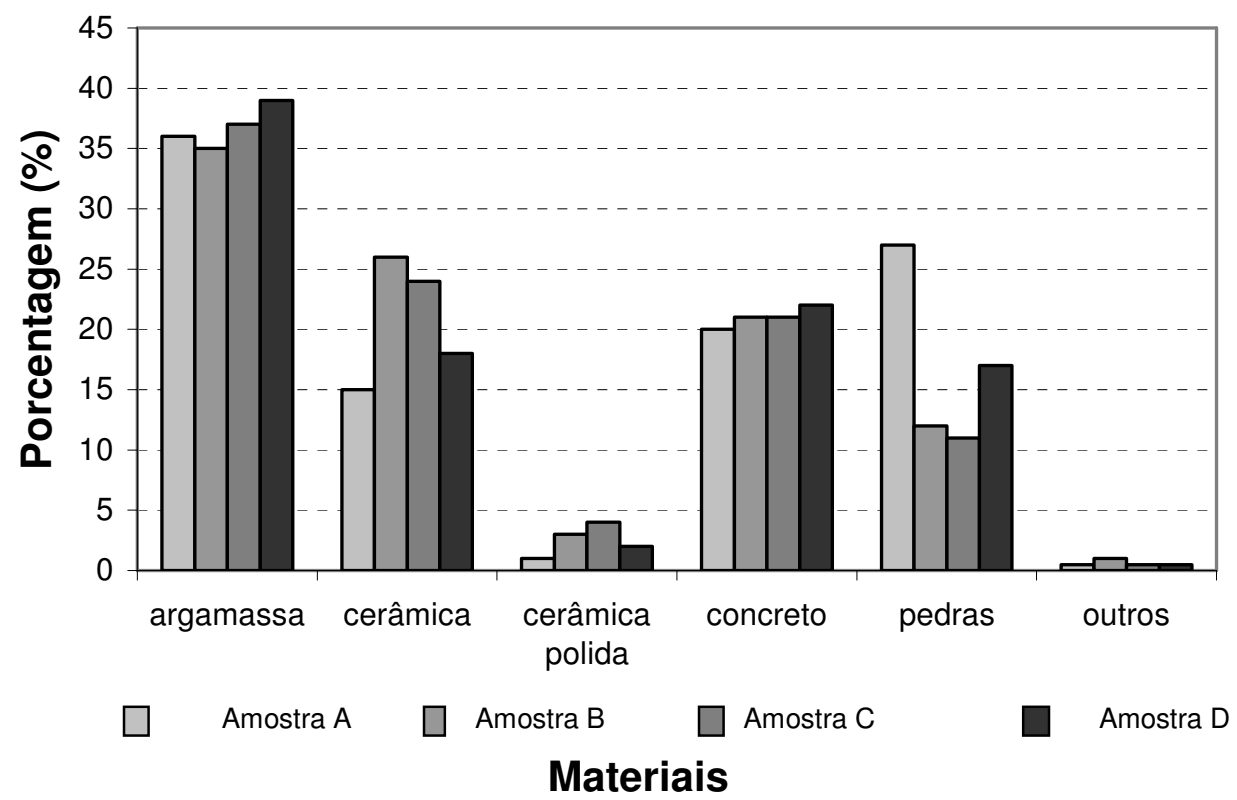

Figura 2.8 - Variabilidade da composição dos agregados de RCD reciclados no Brasil (ZORDAN, 1997).

Conforme apresentado na Figura 2.8, observa-se que fases cerâmicas e pedra podem variar em percentual maior de $10 \%$. As fases concreto e argamassa variaram pouco, pois o método de classificação entre elas era baseado na presença ou não de rocha aderida à argamassa e não em critérios de absorção de água ou resistência mecânica, o que poderia aumentar a variabilidade da composição.

QUEBAUD; BUYLE-BODIN (1999) apresentam uma variabilidade na composição dos agregados reciclados provenientes de resíduos de demolição de habitações locais e pavimentos de concreto, na França, conforme a Tabela 2.6.

Tabela 2.6 - Variabilidade de fases em agregados de RCD reciclados na França.

\begin{tabular}{|l|c|c|c|}
\hline Fases & Mínimo & Máximo & Desvio \\
\hline Cerâmica & 3,60 & 11,00 & 2,6 \\
\hline Asfalto & 1,60 & 5,50 & 1,4 \\
\hline
\end{tabular}

\subsubsection{Variabilidade da granulometrias}

Mantido um mesmo equipamento com mesma regulagem, as curvas granulométricas dos agregados são influenciadas pela concentração das diferentes fases. Em um estudo, em que se trabalhou com agregados reciclados homogêneos de RCD, as 
diferenças são nítidas entre areia proveniente de concreto e areia proveniente de alvenaria. Neste caso, a areia proveniente de alvenaria apresentava juntos materiais cerâmicos e argamassas como uma única fase (ANGULO, 1998).

As conclusões desse estudo podem ser observadas na Figura 2.9.

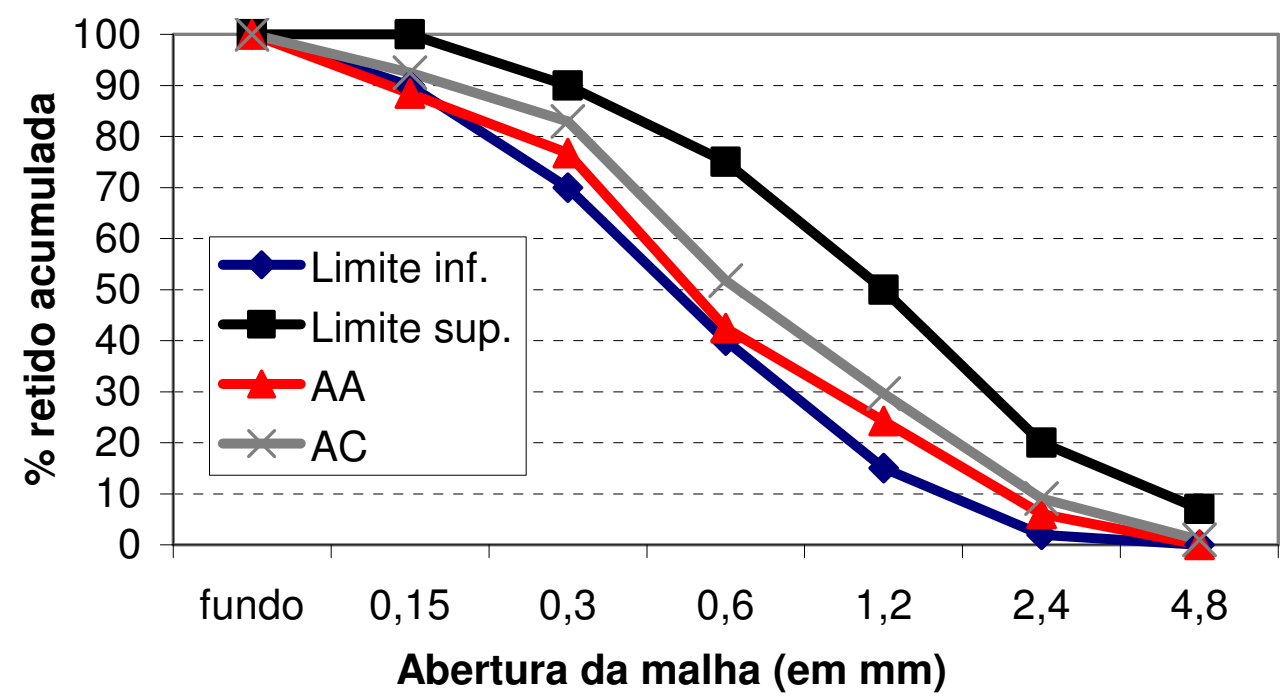

AA - Areia obtida pela britagem de alvenaria (materiais cerâmicos e argamassas).

AC - Areia obtida pela britagem de contrapiso (concreto).

Limite inf.- limite granulométrico inferior proposto pela ASTM C 33.

Limite sup. - limite granulométrico superior proposto pela ASTM C 33.

Figura 2.9 - Curvas granulométricas de agregados de RCD reciclados.

As diferenças nas curvas granulométricas expostas na Figura 2.10 são para agregados reciclados de concreto com a presença de outras fases em menor quantidade. Dentre essas fases, a cerâmica foi a de maior comparecimento nas amostras, apresentando uma variabilidade de $11 \%$. Isto provavelmente causou curvas granulométricas diferenciadas. 


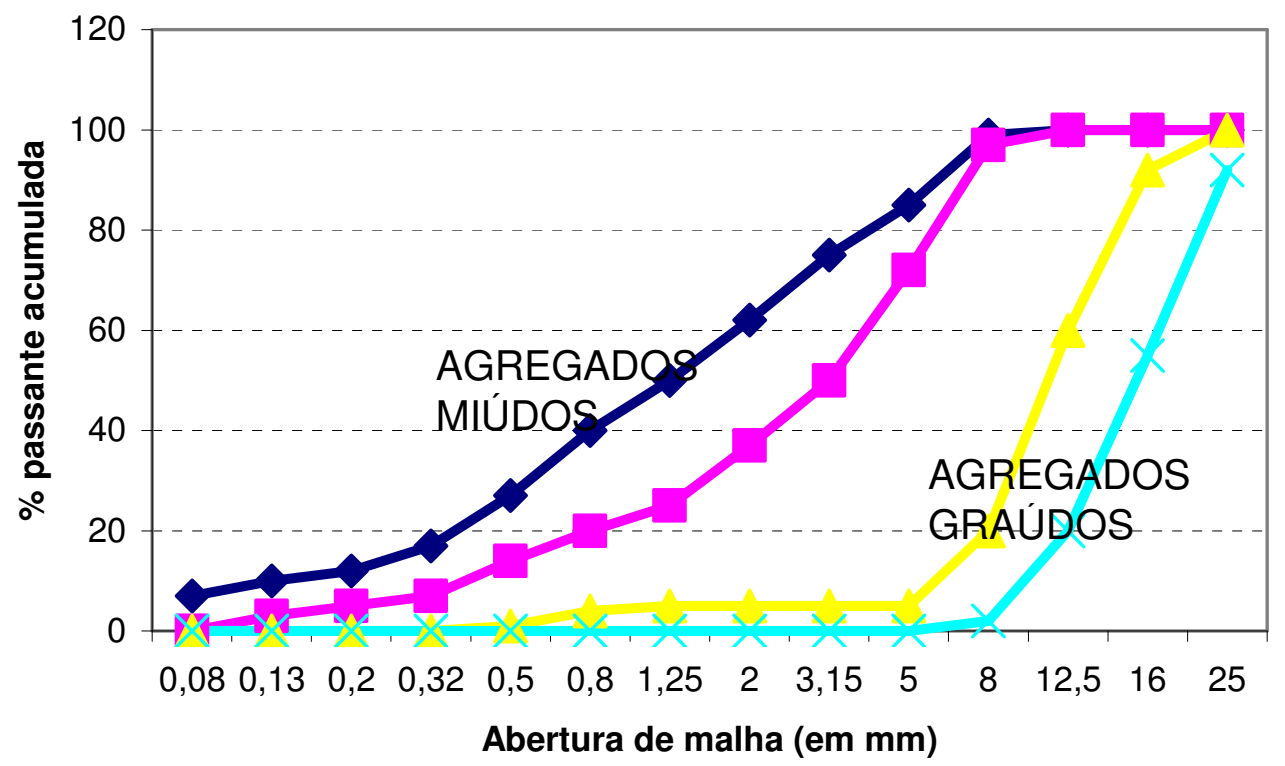

Figura 2.10 - Variabilidade granulométrica de agregados de RCD reciclados (QUEBAUD-BUYLE-BODIN, 1999).

Percebe-se que, pelos dois estudos citados acima, ocorre a variação de curvas granulométricas e que essas variações podem surgir em virtude da predominância de determinadas fases da composição dos agregados de RCD reciclados.

\subsubsection{Variabilidade na forma, textura e abrasão}

A forma e textura dos agregados de RCD reciclados são diferentes da dos agregados naturais. Quanto à forma, aqueles agregados são considerados mais angulares, influindo na trabalhabilidade de argamassas e concretos no estado fresco. A Tabela 2.7 mostra a diferença entre formas de grãos presentes nos agregados reciclados de RCD , em função da fase da composição (LEVY, 1997a).

Tabela 2.7 - Forma dos grãos em função das fases da composição.

\begin{tabular}{|l|c|c|}
\hline \multicolumn{1}{|c|}{ FASES } & FORMA DOS GRÃOS \\
\hline & Esfericidade & Arredondamento \\
\hline Areia natural & $0,9 / 0,7$ & $0,7 / 0,5$ \\
\hline Bloco cerâmico & $0,5 / 0,3$ & $0,5 / 0,3$ \\
\hline Tijolo & $0,7 / 0,5$ & $0,7 / 0,5$ \\
\hline Bloco de concreto & $0,9 / 0,7$ & $0,7 / 0,5$ \\
\hline \multicolumn{2}{|c|}{ Fonte: HAMASSAKI et al., 1997.}
\end{tabular}


Além dessas diferenças, mudanças na textura superficial dos grãos ocorrem; areias têm grãos polidos, cerâmica é levemente áspera e blocos de concreto são ásperos (HAMASSAKI et al., 1997).

\subsubsection{Variabilidade na absorção de água}

A absorção de água dos agregados de RCD pode variar em função da natureza do material e da faixa granulométrica. Agregados de mesma composição apresentaram variações na absorção de água de $5 \%$ para agregados graúdos a $12 \%$ para agregados miúdos (QUEBAUD; BUYLE-BODIN, 1999).

As pastas, sejam elas advindas de concreto ou da argamassa propriamente dita, quando atuam como agregados de RCD reciclados, possuem uma porosidade maior que agregados naturais. Essa porosidade suplementar absorve água e, dependendo da natureza da fase, essa absorção de água pode ser maior ou menor. A Figura 2.11 mostra um levantamento bibliográfico realizado em que se identificam faixas de absorção de água de concretos e argamassas.

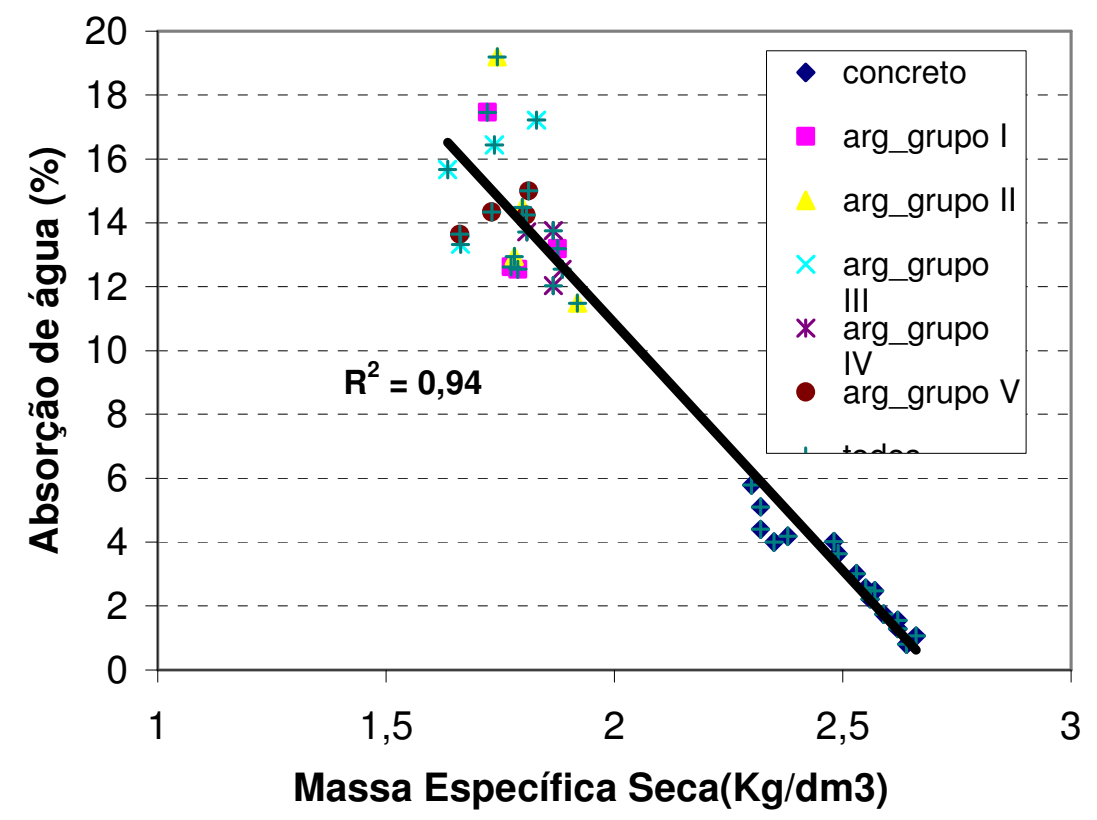

Figura 2.11 - Faixas de absorção de água de concretos e argamassas (elaborada pelo autor a partir das seguintes fontes: KIKUCHI et al., 1994; KASAI et al.,1994; YAMADA et al., 1994; CARNEIRO, 1999; SARAIVA, 1999).

De uma forma geral, conforme observado na Figura 2.11, concretos absorvem em média menos água que argamassas. Percebe-se que os dados estão bem 
diferenciados no gráfico, não ocorrendo sobreposição de valores. Existem, porém, algumas exceções, tais como concretos de contrapiso que possuem alta absorção de água e argamassas colantes que possuem baixa absorção de água (ANGULO, 1998; CARNEIRO, 1999).

Pode-se observar também que a densidade influi na absorção de água dos agregados. Quanto maior a densidade, menor a absorção. Conclusão a que chegou também KREIJGER (1983) apud HANSEN (1992).

Além das fases "concreto" e "argamassa", os agregados de RCD reciclados podem ser constituídos por materiais betuminosos, contaminantes, britas naturais, materiais cerâmicos e blocos de concreto, os quais apresentam propriedade de absorção de água bem diferentes, conforme observado na Tabela 2.8 .

Tabela 2.8 - Absorção de água de alguns materiais processados como agregados miúdos.

\begin{tabular}{|c|c|c|c|c|}
\hline Material & Areia natural & Bloco cerâmico & Tijolo & Bloco concreto \\
\hline Absorção & $0,7 \%$ & $9,6 \%$ & $17,4 \%$ & $5,6 \%$ \\
\hline
\end{tabular}
Fonte: HAMASSAKI et al, 1997.

Dependendo da quantidade de argamassa aderida ao grão de agregados reciclados de concreto, a absorção de água varia numa relação diretamente proporcional. O que confirma o que foi constatado na Figura 2.11. Pode-se observar na Figura 2.12 a relação entre absorção e quantidade de argamassa aderida em volume (HANSEN, 1992).

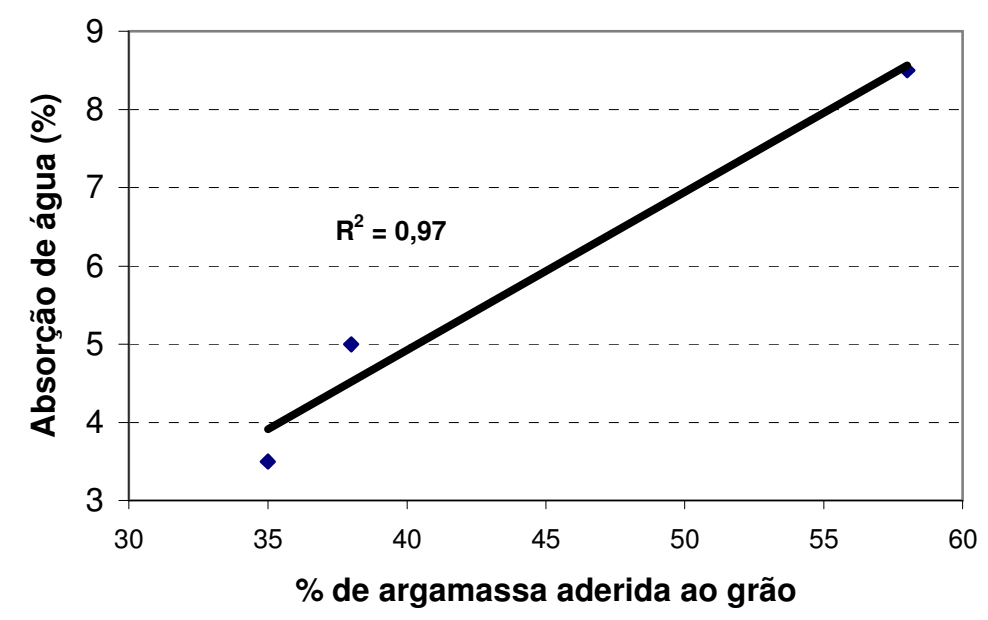

Figura 2.12 - Relação entre absorção de água e quantidade de argamassa aderida ao grão de concreto (HANSEN, 1992). 
Considerando-se a relação água/cimento do concreto original e a dimensão da partícula gerada, a porcentagem de pasta aderida ao grão também varia e, conseqüentemente, a absorção de água.

$\mathrm{O}$ efeito da relação água/cimento é maior quanto menor a dimensão das partículas, com tendência ao aumento da absorção de água em relações água/cimento maiores. Para agregados graúdos esse efeito é desprezível. Quanto ao efeito da dimensão da partícula, nota-se um aumento na quantidade de argamassa aderida ao grão quanto menor a dimensão. A Figura 2.13 ilustra os efeitos mencionados acima.

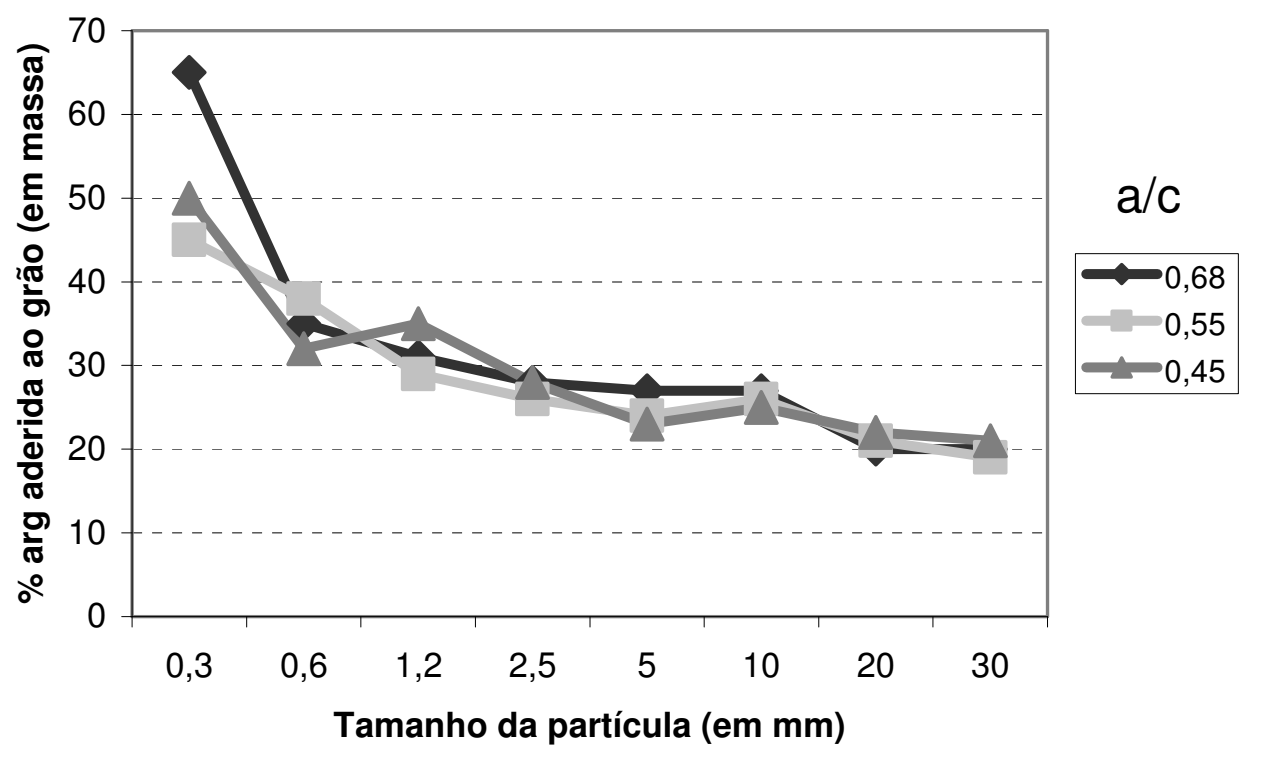

Figura 2.13 - Efeito da relação a/c e dimensão da partícula na \% de argamassa aderida ao grão de agregados de concreto (HANSEN, 1992).

\subsubsection{Variabilidade nas propriedades de argamassas}

A variação da composição influencia na capacidade de retenção de argamassas. LEVY (1997b) argumenta que os melhores resultados de retenção de água foram obtidos para composições de agregados de RCD reciclados com quantidades de material cerâmico acima de $66 \%$ em volume.

$\mathrm{O}$ mesmo autor analisou que a resistência à compressão das argamassas, com predominância de materiais cerâmicos, chegou a ser 2,5 vezes superiores às demais, variando apenas $5 \%$ do consumo de cimento. Foi detectada atividade pozolânica do material cerâmico, podendo ter havido influência do "efeito filler", que é um efeito não 
completamente conhecido. Foi também detectado que um alto teor de materiais cerâmicos não afetou a velocidade de carbonatação das argamassas.

HAMASSAKI et al. (1997) variaram composições dos agregados de RCD reciclados entre blocos cerâmicos, tijolos cerâmicos e blocos de concreto. A Figura 2.14 e Figura 2.15 demonstram os efeitos dessas variações nas propriedades das argamassas. Os tipos de I a VII observados nos gráficos são as diferentes composições estudadas. Como destaque, a composição VII é a que apresenta maior teor de tijolos e não possui areia natural. A composição I é a de referência com agregados naturais.

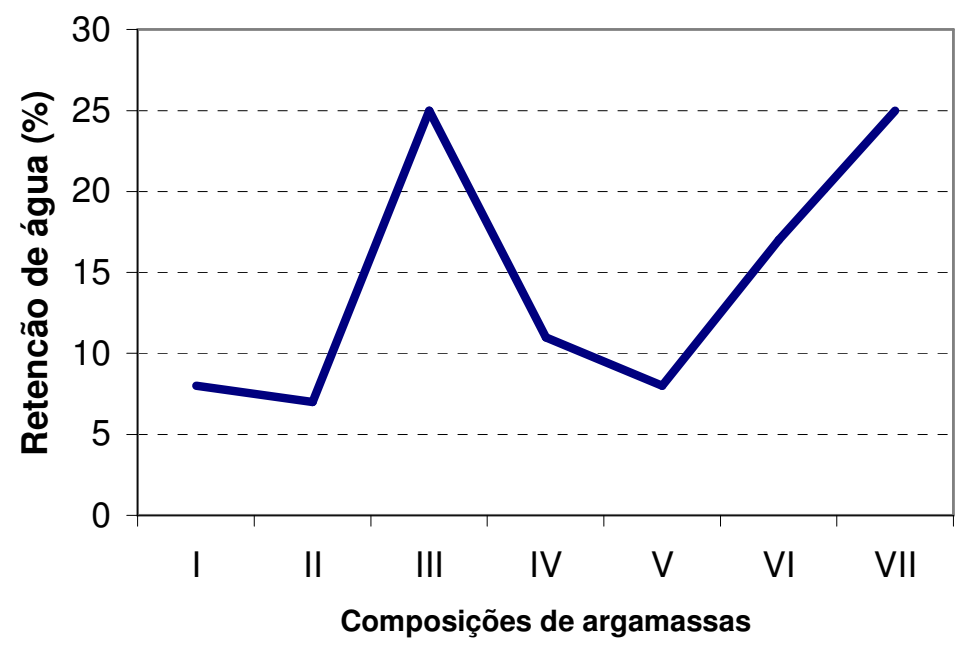

Figura 2.14 - Retenção de água de argamassas com diversas composições de agregados (HAMASSAKI et al., 1997).

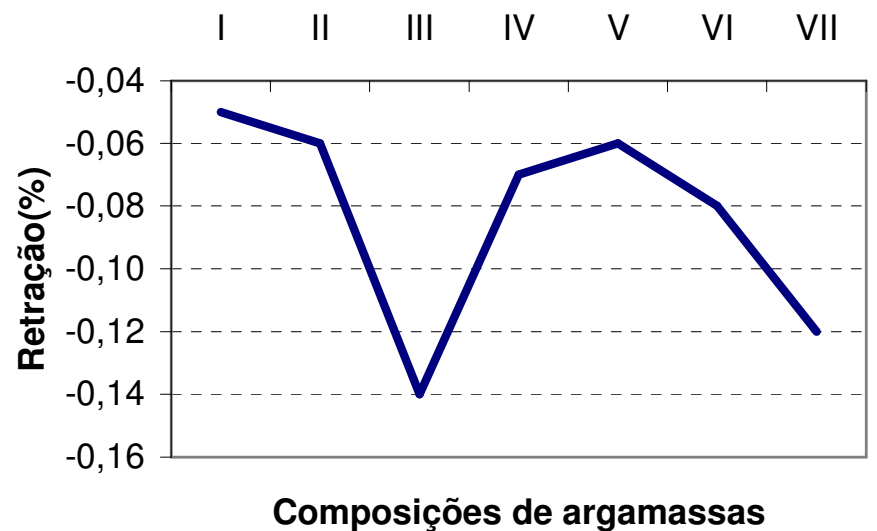

Figura 2.15 - Retração por secagem das argamassas com diferentes composições de agregados (HAMASSAKI et al., 1997). 
Percebe-se um aumento significativo na capacidade de retenção de água em composições de altos teores de cerâmica, bem superior à retenção obtida para argamassas convencionais. Para as demais composições, é nítida a variabilidade que a composição causa na propriedade. Efeito semelhante pode ser observado na retração por secagem.

\subsubsection{Variabilidade nas propriedades de concretos plásticos}

A consistência de concretos frescos se altera em função da natureza das composições, o que pode afetar significativamente os processos produtivos dos mesmos. ${ }^{3}$ A Figura 2.16 mostra uma variação detectada para diferentes composições.

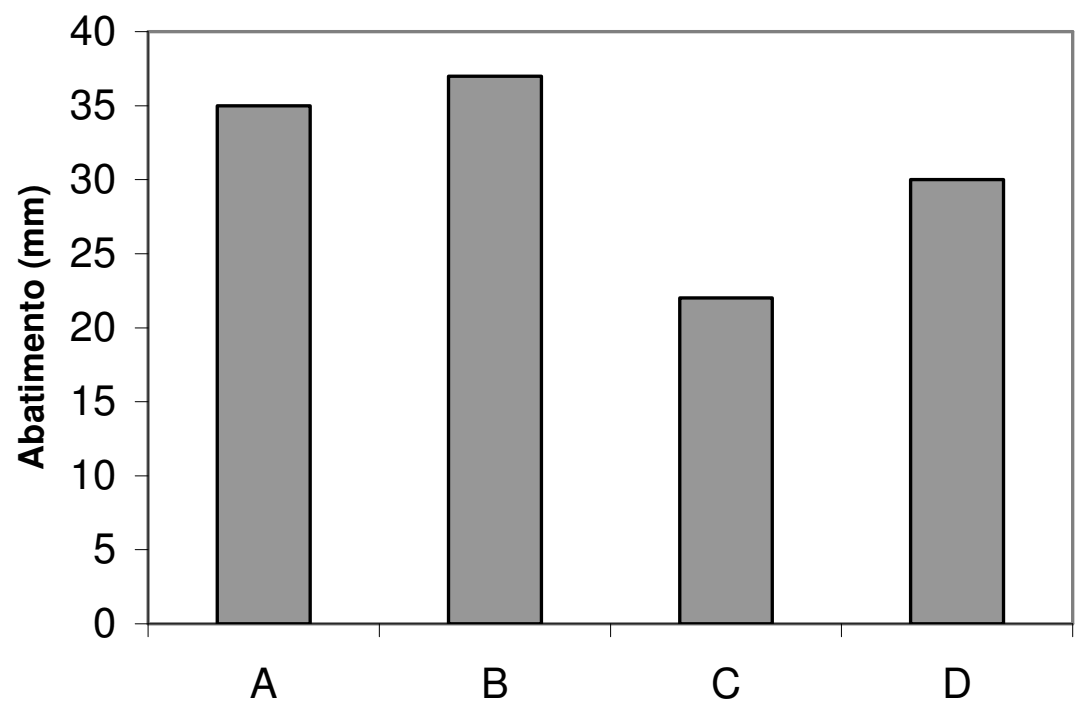

\section{Composições}

Figura 2.16 - Variação do abatimento em função da composição, para traços 1:3 (ZORDAN, 1997).

A variabilidade na resistência à compressão e no desgaste por abrasão é menos significativa, mas também existe. A permeabilidade dos concretos apresentou bastante variação (ZORDAN, 1997).

${ }^{3}$ Problemas detectados na produção de bloquetes na Prefeitura de Santo André indicaram variações de consistência em função dos lotes de agregados reciclados utilizados, segundo Gilson Lameira e Marcos Tamai, responsáveis operacionais pela Central. 


\subsection{NORMALIZAÇÃO DE AGREGADOS GRAÚDOS DE RCD RECICLADOS PARA CONCRETO}

Existem especificações para a utilização de agregados graúdos de RCD reciclados em concretos, retidos em malhas de peneira acima de $4 \mathrm{~mm}$. A recomendação define três tipos de agregados, definidos abaixo (RILEM RECOMMENDATION, 1994):

Tipo I: agregados originados predominantemente de resíduos de alvenaria.

$>$ Tipo II: agregados originados predominantemente de resíduos de concreto.

> Tipo III: agregados obtidos da mistura de agregados reciclados e naturais.

A Tabela 2.9 demonstra os critérios exigidos para a utilização em concretos. Além desses apresentados, outros também devem ser considerados, tais como granulometria, índice de forma, resistência à abrasão, teor de cloretos, teores de ferro, vanádio e cálcio e resistência ao congelamento. Ainda, deve-se levar em conta requisitos de saúde, como contaminação por metais pesados, lixiviação e radiação.

Tabela 2.9 - Classificação dos agregados graúdos de RCD reciclados para concreto (RILEM RECOMMENDATION, 1994)。

\begin{tabular}{|c|c|c|c|c|}
\hline \multirow[t]{2}{*}{ Especificações } & \multicolumn{3}{|c|}{$\begin{array}{c}\text { Concreto com agregado graúdo } \\
\text { reciclado }\end{array}$} & \multirow[t]{2}{*}{ Método de Ensaio } \\
\hline & tipo I & tipo II & tipo III & \\
\hline Massa Específica mínima material seco (Kg/m3) & 1500 & 2000 & 2400 & ISO $6783 \& 7033$ \\
\hline Absorção de água máxima (\%) & 20 & 10 & 3 & ISO $6783 \& 7033$ \\
\hline Quantidade máxima de material SSS $<2200 \mathrm{Kg} / \mathrm{m} 3(\%)^{\text {a }}$ & & 10 & 10 & ASTM C123 \\
\hline Quantidade máxima de material SSS < $1800 \mathrm{Kg} / \mathrm{m} 3(\%)$ & 10 & 1 & 1 & ASTM C123 \\
\hline Quantidade máxima de material SSS < $1000 \mathrm{Kg} / \mathrm{m} 3(\%)$ & 1 & 0,5 & 0,5 & ASTM C123 \\
\hline Quantidade máxima de impurezas (vidro, betume, plásticos) (\%) & 5 & 1 & 1 & Visual \\
\hline Quantidade máxima de metais (\%) & 1 & 1 & 1 & Visual \\
\hline Quantidade máxima de matéria orgânica (\%) & 1 & 0,5 & 0,5 & NEN 5933 \\
\hline Quantidade máxima de finos < 0,063 mm (\%) & 3 & 2 & 2 & prEN 933-1 \\
\hline Quantidade máxima de areia $<4 \mathrm{~mm} \mathrm{( \% )}{ }^{b}$ & 5 & 5 & 5 & prEN 933-1 \\
\hline Quantidade máxima de sulfatos (\%) ${ }^{\mathrm{c}}$ & 1 & 1 & 1 & BS 812, part 118 \\
\hline \multicolumn{5}{|c|}{${ }^{\mathrm{a}}$ Condição saturada com superfície seca } \\
\hline \multicolumn{5}{|c|}{$\begin{array}{l}{ }^{\mathrm{b}} \text { Se for excedido o limite de fração areia, esta parte deverá ser considerada como parte da areia total a ser utilizada } \\
{ }^{c} \text { Quantidade de sulfato deve ser calculada como } \mathrm{SO}_{3}\end{array}$} \\
\hline \multicolumn{5}{|l|}{$\begin{array}{l}\text { As porcentagens constantes na tabela referem-se à massa/massa } \\
\text { SSS - Agregado na condição de superfície saturada seca }\end{array}$} \\
\hline
\end{tabular}

Percebe-se aqui a importância do controle de composição e de características físicas dos agregados. Parâmetros como massa específica, absorção de água, análise visual de fases (vidros, betume, plásticos, metais) e teores de materiais pulverulentos são controlados. As frações finas de agregados de RCD reciclados também estão com seu uso limitado, o que prejudica a viabilidade da reciclagem de RCD, uma vez que é significativa a quantidade de agregados de RCD miúdos, em alguns casos. 
O controle de sulfatos, limitado a $1 \%$, pode ser questionado com base no estudo de GALLIAS (1998), podendo este limite ser estendido, conforme discutido no item 2.3.

COLLINS (1998) refere que a Europa está formulando especificações de agregados de RCD reciclados, padronizando os produtos gerados, as quais também irão conter procedimentos de controle de qualidade e controle de entrada de materiais em plantas de reciclagem.

Neste contexto, fica enfatizada a necessidade de controle de composição de fases e de características físicas dos agregados de RCD. Porém, a recomendação só direciona o uso para concretos. Estudos mais detalhados para demais componentes devem ser realizados.

No Brasil, LIMA (1999) apresenta diretrizes para a produção, normalização e uso de agregados de RCD reciclados. Neste trabalho, existe uma proposta de especificação desses agregados para o emprego em concretos. 


\section{MÉTODOS DE ESTUDO DE COMPOSIÇÃO DE AGREGADOS DE RCD RECICLADOS}

A composição de agregados de RCD reciclados pode ser avaliada por técnicas de separação manual, absorção de água/massa específica, análise de imagem e ensaios químicos e físicos.

Para agregados graúdos, as técnicas aplicadas são separação manual e análise de imagem. Para agregados miúdos, as técnicas de possível aplicação são SQDRX (Difração de Raios X pelo Método Semi-quantitativo), DSC (Calorimetria Exploratória), TG (Termogravimetria), entre outras.

Para este trabalho, só serão discutidas técnicas voltadas para a caracterização da composição de agregados graúdos de RCD reciclados, como separação manual, absorção de água/massa específica e análise de imagem.

\subsection{SEPARAÇ̃̃O MANUAL}

A avaliação da composição de agregados graúdos de RCD reciclados, segundo técnica de separação manual, utiliza os seguintes critérios (PINTO, 1986; RILEM RECOMMENDATION, 1994; ZORDAN, 1997):

$>$ lavagem do material para a retirada da fração fina aderida no agregado, que dificulta a análise visual da composição;

$>$ permanência em estufa durante 24 horas a $105-110^{\circ} \mathrm{C}$;

$>$ seleção manual e pesagem das fases.

Podem ser definidas as seguintes fases para a seleção manual (ZORDAN, 1997):

$>$ argamassa: parcela que visualmente contém areia e material aglutinante sem a presença de agregados graúdos.

concreto: parcela que visualmente contém areia, cimento e brita no agregado.

$>$ pedras: fragmentos de rochas, podendo possuir alguma parcela de argamassa, na análise visual. 
cerâmica: material cerâmico não polido, composto de tijolos, blocos e telhas cerâmicas, na análise visual.

cerâmica polida: material cerâmico constituído de pelo menos uma superfície polida, na análise visual.

O que se questiona para este método é a seleção das fases "concreto" e "argamassa", pois os agregados se apresentam nas formas mais variadas: concretos excessivamente porosos, como concretos de contrapiso, e argamassas pouco porosas, como argamassas colantes. Outro problema consiste na diferenciação de pedra e concreto.

Portanto, o método de separação manual não se revela adequado para separar as fases "concreto", "pedras" e "argamassa", já que a característica fundamental de diferenciação é a absorção de água, conforme mencionado no item 2.4 e 2.5.

\subsection{ANÁLISE DE IMAGEM}

A análise de imagem ou DIP (Digital Image Processing) é uma técnica que captura uma cena bidimensional e a digitaliza, de tal forma que toda a informação aí contida pode ser analisada, segundo características de forma, cor, contagem de partículas e distribuições espaciais. A correlação com a tridimensionalidade pode ser fornecida indiretamente pela sombra das partículas no plano (MORA et al., 1998; BARKSDALE et al., 1991).

O processo de digitalização da imagem gera uma matriz de números que pode ser processada matematicamente. Nesse contexto, o "pixel" é definido como a unidade básica do processo de digitalização ou menor unidade da resolução (RUSS, 1990; GABAS, 1999).

Um dos processos da análise da imagem mais utilizado é a segmentação, em que a imagem é dividida em áreas de interesse, segundo unidades estruturais, cenas ou objetos. Uma determinada área de interesse pode ser entendida como fase. Em imagens bidimensionais, as coordenadas de cores podem ser utilizadas, tais como RGB (Red, Green, Blue), HSI (Hue, Saturation, Intensity), etc (RUSS, 1994).

RUSS (1994) afirma que o modelo RGB é importante em síntese de análises digitais. Este modelo é empregado em artefatos de processamento digital, como alguns monitores e algumas câmeras em cores. No modelo RGB, uma cor é expressa em termos da intensidade de vermelho, verde e azul que ela contém. 
O modelo RGB pode ser um sistema de 24, 36 ou 48 bits, podendo armazenar 8,12 a 16 bits por componente do sistema. Entende-se como bit uma unidade de informação com resultado entre duas possíveis alternativas (zero e um) num sistema de código binário, utilizada como unidade de memória de computador. ${ }^{4}$ Para o caso de 8 bits, as combinações possíveis por permutação são o resultado de $2^{8}$, que são 256 . Para este caso, numa cor do sistema RGB, zero significa preto e 256 a cor mais brilhante ou vívida (RUSS, 1994; GABAS, 1999).

Existem outros sistemas de cores, como o modelo HSI, sendo as letras identificadas por "hue", "saturation" e "intensity". "Hue" equivale ao pigmento (amarelo, cian, magenta, etc). "Saturation" indica a quantidade de cor presente, distinguindo um vermelho de um rosa por exemplo. "Intensity" define a quantidade de luz presente, diferenciando um vermelho escuro de um vermelho claro por exemplo. Existe um sistema de equações que converte as coordenadas de RGB em coordenadas de HSI (RUSS, 1994).

Na Figura 3.1 são expostos os dois tipos de escalas de cores mencionados.
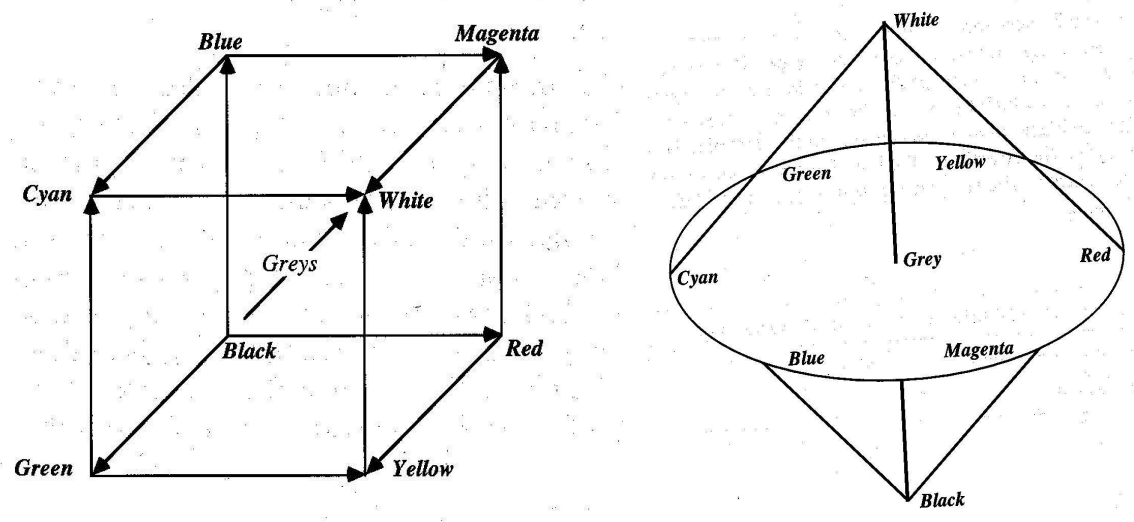

Figura 3.1 - Escalas de cores RGB (esquerda) e HSI (direita) (RUSS,1994).

A técnica de análise de imagem tem sido bastante difundida em áreas como Medicina, Biologia, Geografia, Meteorologia, Engenharia e Ciência dos Materiais. Na Engenharia Civil, por exemplo, a técnica tem sido usada para analisar tamanho, forma, distribuição de grãos e poros de solos arenosos, microestrutura de concreto, fissuras em pavimentos e deformações estruturais (KWAN et al., 1999).

${ }^{4}$ Definição obtida no site www.britannica.com, que é o site da Enciclopédia Britânica. 
As correlações empregadas por KWAN et al. (1999) e MORA et al. (1998) utilizam como princípio uma relação entre área e volume. Nas fórmulas empregadas, os pesquisadores retiraram uma expressão de espessura média das partículas para obtenção de volume e, como consequiência, a massa, quando conhecida a massa específica do material.

O estudo de estruturas tridimensionais a partir de imagens bidimensionais é conhecido como Estereologia. Como requisitos para esse estudo destaca-se a necessidade de não orientação da amostra e de distribuir-se aleatoriamente as partículas (GABAS, 1999).

A caracterização de forma e composição granulométrica de agregados graúdos é realizada com sucesso, quando se aplica a técnica de análise de imagem (BARKSDALE et al., 1991; LI et al., 1993; KUO et al., 1996; MORA et al., 1998; KWAN et al, 1999). Destaca-se a possibilidade de sua aplicação para agregados miúdos, com ressalvas à sobreposição dos grãos, que necessitam de espalhamento mecânico (MORA et al., 1998; KWAN et al, 1999).

ANDRADE et al. (2000) estudaram a composição granulométrica de partículas de argila de 90 a $600 \mu \mathrm{m}$ por análise de imagem, empregadas na produção de materiais cerâmicos. Os autores utilizaram ondas sonoras de $30 \mathrm{~Hz}$ para garantir a dispersão dos grãos. O método foi considerado eficaz, além de ser mais preciso que peneiramento mecânico e com custo inferior à difração a laser.

Outro estudo adotou radiação infravermelha para a classificação de resíduos de demolição. Aplicada com sucesso na separação entre fases orgânicas e inorgânicas, apresentou, no entanto, dificuldades na separação e classificação entre fases inorgânicas (GROOT et al., 1999).

Apesar de adotada com resultados satisfatórios, a técnica de análise de imagem, quando aplicada a frações miúdas de agregados, necessita de aperfeiçoamentos para garantir a não-sobreposição ou a visualização dos grãos.

Pode ser empregada também, todavia, sem restrições para as caracterizações de forma e granulometria de agregados graúdos. Para o estudo da composição, a segmentação por cores das fases também pode ser realizada, uma vez que a separação manual é baseada no que o olho humano consegue distinguir, e a segmentação por cores se baseia no mesmo princípio. 
A Tabela 3.1 mostra alguns parâmetros que podem ser utilizados para a diferenciação das fases.

Tabela 3.1 - Parâmetros para a diferenciação de fases por análise de imagem

\begin{tabular}{|c|c|c|}
\hline Fases & Cor & Textura \\
\hline Concreto & Cinza & Lisa \\
\hline Cerâmica & Vermelha & Muito lisa \\
\hline Argamassa & Marrom/cinza & Fibras orientadas \\
\hline Madeira & Marrom & lisa \\
\hline Pedras & Variáveis & \\
\hline
\end{tabular}

A coincidência de tons e cores pode gerar dificuldades na identificação do grão na separação de fases, requerendo ajustes por processos não-automáticos.

Para otimizar o tempo empregado na análise pode-se aplicar filtros de imagem que facilitam a separação entre as fases. Esses filtros podem ser de diversos tipos, segundo IMAGE PRO PLUS (1998):

Filtros de realce: realçam contrastes e detalhes, e removem interferências. São eles: "lo-pass", "hi-pass", "gauss", "hi-gauss", "sharpen”, “flatten”, "local equalize”, "median", "rank" e "threshold".

Filtros de borda: enfatizam e realçam contornos. São eles: "sobel", "laplace", "roberts", "variance" e "phase".

Filtros morfológicos: modificam a forma e tamanho dos objetos, revelam e enfatizam pontos. São eles : “erode”, “dilate”, “open”, “close”, “tophat”, “well”, "watershed", "thinning", "pruning", "distance", "reduce" e "branch".

Filtros especiais: extraem fundos e criam efeitos de escultura. São eles: "sculpt" e "background".

Em seguida, serão definidos alguns filtros, acima classificados, que podem ser empregados no método de caracterização da composição dos agregados graúdos de RCD por análise de imagem (RUSS, 1984; IMAGE PRO PLUS, 1990; GABAS, 1999; ANDRADE et al., 2000):

Filtro OPEN: regulariza os contornos dos objetos, separa objetos estreitamente conectados e remove pequenos buracos escuros, em imagens contendo objetos claros em fundo escuro. Usa princípios de erosão (remove pequenas conectividades de "pixels" e elimina pontos espúrios) e dilatação (conecta "pixels"), nesta sequiência. Utiliza operações morfológicas e é global (atinge toda a imagem). A 
erosão troca "pixels" "on" por "pixels" "off" de cada "pixel” binário. A dilatação faz o processo inverso.

Filtro LAPLACE: melhora o realce das imagens. A matriz mínima deste operador é 3 x 3. São matrizes simétricas que geram valores negativos, os quais produzem resultados nulos em regiões uniformes da imagem e significativas modificações em bordas, linhas e pontos.

Filtro THRESHOLD: define um intervalo de valores de brilho em uma imagem original, selecionando os "pixels" que se encontram neste intervalo como pertencentes ao primeiro plano, rejeitando todos os outros para o plano de fundo. Transforma a imagem em um binário, usando preto e branco.

\subsection{ABSORCÃO DE ÁGUA E MASSA ESPECÎFICA}

A absorção de água e/ou a massa específica seca podem ser utilizadas para diferenciar fases presentes na composição dos agregados reciclados de RCD, pois as fases possuem faixas de valores bem características para essas propriedades, conforme mencionado no item 2.4.4. A recomendação da RILEM para agregados graúdos reciclados usa essas propriedades para classificar e controlar a composição (RILEM RECOMENDATIONN, 1994).

Em razão das dificuldades encontradas na seleção das fases "concreto" e "argamassa" na técnica de inspeção visual, montou-se um gráfico de correlação entre absorção de água e massa específica seca para concretos e argamassas, que foi utilizado para a separação dessas fases e será comentado no capítulo 4.

Os dados de absorção de água e massa específica de agregados reciclados de concreto foram retirados do $3^{\circ}$ Simpósio Internacional RILEM de demolição e reuso (sic) do concreto, do ano de 1993, apresentados na Tabela 3.2. 
Tabela 3.2 - Levantamento dos dados de agregados graúdos reciclados de concreto.

\begin{tabular}{|c|c|c|c|c|c|c|c|c|}
\hline agregado & notação & $\begin{array}{l}\text { grau de } \\
\text { britagem }\end{array}$ & $\begin{array}{l}\text { resistência } \\
\text { do concreto } \\
\text { original }\end{array}$ & $\begin{array}{l}\text { massa } \\
\text { específica }\end{array}$ & $\begin{array}{l}\text { absorção } \\
(\%)\end{array}$ & $\begin{array}{l}\text { taxa de } \\
\text { argamassa } \\
\text { aderida }\end{array}$ & $\begin{array}{c}\text { resistência à } \\
\text { compressão } \\
(\mathrm{MPa})\end{array}$ & referência \\
\hline $\begin{array}{l}\text { high- } \\
\text { grade }\end{array}$ & R1 & $2 \times$ rolos & & 2,64 & 0,8 & 9,9 & 28,0 & YAMADA \\
\hline $\begin{array}{l}\text { high- } \\
\text { grade }\end{array}$ & R1 & $2 \times$ rolos & & 2,62 & 1,29 & 7,3 & 28,0 & 1993 \\
\hline $\begin{array}{l}\text { medium- } \\
\text { grade }\end{array}$ & $\mathrm{R} 2$ & rolos & & 2,59 & 1,74 & 26 & 28,0 & \\
\hline $\begin{array}{l}\text { medium- } \\
\text { grade }\end{array}$ & $\mathrm{R} 2$ & rolos & & 2,56 & 2,22 & 16,7 & 28,0 & \\
\hline low-grade & R3 & impacto & & 2,53 & 3,02 & 40,2 & 28,0 & \\
\hline low-grade & R3 & impacto & & 2,49 & 3,64 & 35,2 & 28,0 & \\
\hline reciclado & RG1 & martelo & & 2,35 & 4 & & 65,6 & $\mathrm{KIKUCHI}$ \\
\hline reciclado & RG2 & martelo & & 2,32 & 4,4 & & 46,2 & 1993 \\
\hline reciclado & RG3 & martelo & & 2,32 & 5,1 & & 22,5 & \\
\hline reciclado & & & & 2,3 & 5,79 & & & KASAI \\
\hline reciclado & & primário & alta & 2,48 & 4,02 & 41,7 & 40,0 & KASAI \\
\hline reciclado & & primário & baixa & 2,38 & 4,18 & 29,4 & 20,0 & 1993 \\
\hline reciclado & & $\begin{array}{l}\text { intermediá } \\
\text { rio }\end{array}$ & alta & 2,57 & 2,48 & 26,5 & 40,0 & \\
\hline reciclado & & $\begin{array}{l}\text { intermediá } \\
\text { rio }\end{array}$ & baixa & 2,55 & 2,56 & 20,6 & 20,0 & \\
\hline reciclado & & alto & alta & 2,62 & 1,55 & 10,8 & 40,0 & \\
\hline reciclado & & alto & baixa & 2,66 & 1,06 & 2,5 & 20,0 & \\
\hline
\end{tabular}

Os dados de agregados graúdos reciclados de argamassa foram obtidos diretamente de argamassas e não de agregados, conforme valores no III Simpósio Brasileiro de Tecnologia da Argamassa, realizado no ano de 1999, e tese de doutorado da Escola Politécnica de autoria de CARNEIRO (1999). A Tabela 3.3 mostra esses dados. 
Tabela 3.3 - Levantamento de dados de argamassa pela bibliografia.

\begin{tabular}{|c|r|r|r|r|}
\hline Argamassa & $\begin{array}{l}\text { Massa } \\
\text { específica } \\
\text { seca }\end{array}$ & $\begin{array}{r}\text { resistência à } \\
\text { compressão }\end{array}$ & Absorção & referência \\
\hline & 2,31 & 2,46 & & SARAIVA \\
\hline & 2,54 & 10,07 & & 1999 \\
\hline Grupo I & 1,72 & 0,03 & 17,46 & CARNEIRO \\
\hline & 1,79 & 2,94 & 12,54 & 1998 \\
\hline & 1,77 & 3,77 & 12,62 & \\
\hline & 1,88 & 4,87 & 13,19 & \\
\hline Grupo II & 1,92 & 0,12 & 11,48 & \\
\hline & 1,78 & 3,37 & 12,95 & \\
\hline & 1,80 & 4,76 & 14,48 & \\
\hline & 1,74 & 5,39 & 19,19 & \\
\hline Grupo III & 1,66 & 0,24 & 13,33 & \\
\hline & 1,64 & 4,34 & 15,67 & \\
\hline & 1,74 & 5,83 & 16,44 & \\
\hline & 1,83 & 6,36 & 17,22 & \\
\hline Grupo IV & 1,87 & 4,42 & 12,03 & \\
\hline & 1,89 & 5,82 & 12,54 & \\
\hline & 1,81 & 6,96 & 13,72 & \\
\hline & 1,87 & 8,88 & 13,75 & \\
\hline Grupo V & 1,66 & 1,72 & 13,64 & \\
\hline & 1,81 & 4,98 & 14,24 & \\
\hline & 1,73 & 6,55 & 14,34 & \\
\hline & 1,81 & 8,00 & 15,00 & \\
\hline
\end{tabular}

A partir desse levantamento, criou-se uma nuvem de dispersão de resultados, correlacionando massa específica seca e absorção de água. Percebe-se, pela Figura 2.11, que esses valores se encontram bem separados e definidos, tendo valores médios bem distintos. Os dados apresentaram pouca variabilidade em relação a uma reta de referência.

Os valores médios de massa específica seca foram $2,5 \mathrm{Kg} / \mathrm{dm} 3$ para agregados graúdos reciclados de concreto e $1,75 \mathrm{Kg} / \mathrm{dm} 3$ de agregados graúdos reciclados de argamassa. Os valores de absorção de água médios foram 3,25\% e 15\%, respectivamente.

\subsection{COMENTÁRIOS FINAIS}

No Brasil, os métodos disponíveis para a caracterização da composição estão pouco explorados, sendo ainda provenientes de incipientes pesquisas. O método de separação manual tem sido empregado nas caracterizações dos RCD e, pioneiramente, 
em agregados graúdos de RCD reciclados por ZORDAN (1997). Este trabalho possui, porém, imprecisões na definição de fases.

O método de análise de imagem não tinha sido empregado para a caracterização de fases dos agregados de RCD reciclados até o presente trabalho. O seu potencial de utilização, já observado, é relevante, assim como a possibilidade de obtenção de outras informações dos agregados, como granulometria e índice de forma.

A absorção de água das fases presentes nos agregados de RCD reciclados é bem característica, sendo um parâmetro de boa confiabilidade para a seleção de determinadas fases. Ela não deve ser utilizada como parâmetro único, uma vez que seu valor é resultado da combinação dessas absorções características das fases; pode ser utilizada em combinação com outros métodos.

Internacionalmente, os controles de composição são realizados por separação manual, controlando a presença de fases secundárias comparadas com a predominante, nestes casos, concreto ou alvenaria (argamassa e cerâmica). 


\section{PROGRAMA EXPERIMENTAL, MATERIAIS E MÉTODOS}

\subsection{RESUMOS DOS PROCEDIMENTOS ADOTADOS}

Este programa experimental teve início no estudo da composição de agregados graúdos de RCD reciclados por análise de imagem. Nesta etapa, utilizou-se um programa de análise de imagem e tentou-se desenvolver um método pelo qual seria possível avaliar as fases da composição pela área em imagens planas e correlacionar com a massa das mesmas. Neste estudo foram utilizados somente agregados graúdos de $\mathrm{RCD}$ reciclados produzidos em laboratório.

Nos resultados obtidos nesta etapa constatou-se a dificuldade em separar as fases concreto e argamassa pelo método de análise de imagem. Considerando-se este fato, partiu-se para uma segunda etapa do programa experimental que tinha como objetivo avaliar a composição de concreto e argamassa a partir das propriedades de absorção de água e de massa específica, conforme constatado no capítulo 3. Nesta segunda etapa foram utilizados também agregados graúdos de RCD reciclados obtidos em laboratório.

Após a obtenção desses resultados, prosseguiu-se para a terceira e última etapa do programa que foi avaliar a variabilidade de agregados graúdos de RCD reciclados obtidos em uma Central de Reciclagem, segundo determinadas características físicas selecionadas. Nesta etapa, aplicou-se o método desenvolvido na segunda etapa do programa.

A metodologia de análise de imagem não foi aplicada em amostras de agregados obtidas na Central de Reciclagem, considerando-se os seguintes itens:

a) no método de análise de imagem, quando se correlaciona área com a massa dos agregados, é necessário a determinação da massa específica das fases da composição. Para isto, é necessário separar as fases manualmente para posteriormente determinar, o que inviabiliza o método; 
b) uma forma de se evitar a separação manual das fases, para a determinação dos valores de massa específica, é adotar valores médios para as fases. Para isso, é necessário determinar esses valores nas amostras de uma Central para posteriormente aplicar o método de análise de imagem, estendendo o período desta pesquisa;

c) na revisão bibliográfica, os autores MORA (1998) e KWAN (1999) determinaram a distribuição granulométrica e índice de forma de agregados por método de análise de imagem. A compatibilização entre métodos é necessária para aumento da viabilidade do emprego da técnica. O trabalho experimental necessário seria inviável com o período destinado a esta pesquisa.

Desta forma, através do programa experimental, procurou-se atingir os objetivos propostos no início desta dissertação, que são:

- Estudar a aplicação da técnica de análise de imagem para a avaliação da composição dos agregados graúdos de RCD reciclados,

- Quantificar a variabilidade da composição e características físicas desses agregados.

A Figura 4.1 mostra um fluxograma do programa experimental.

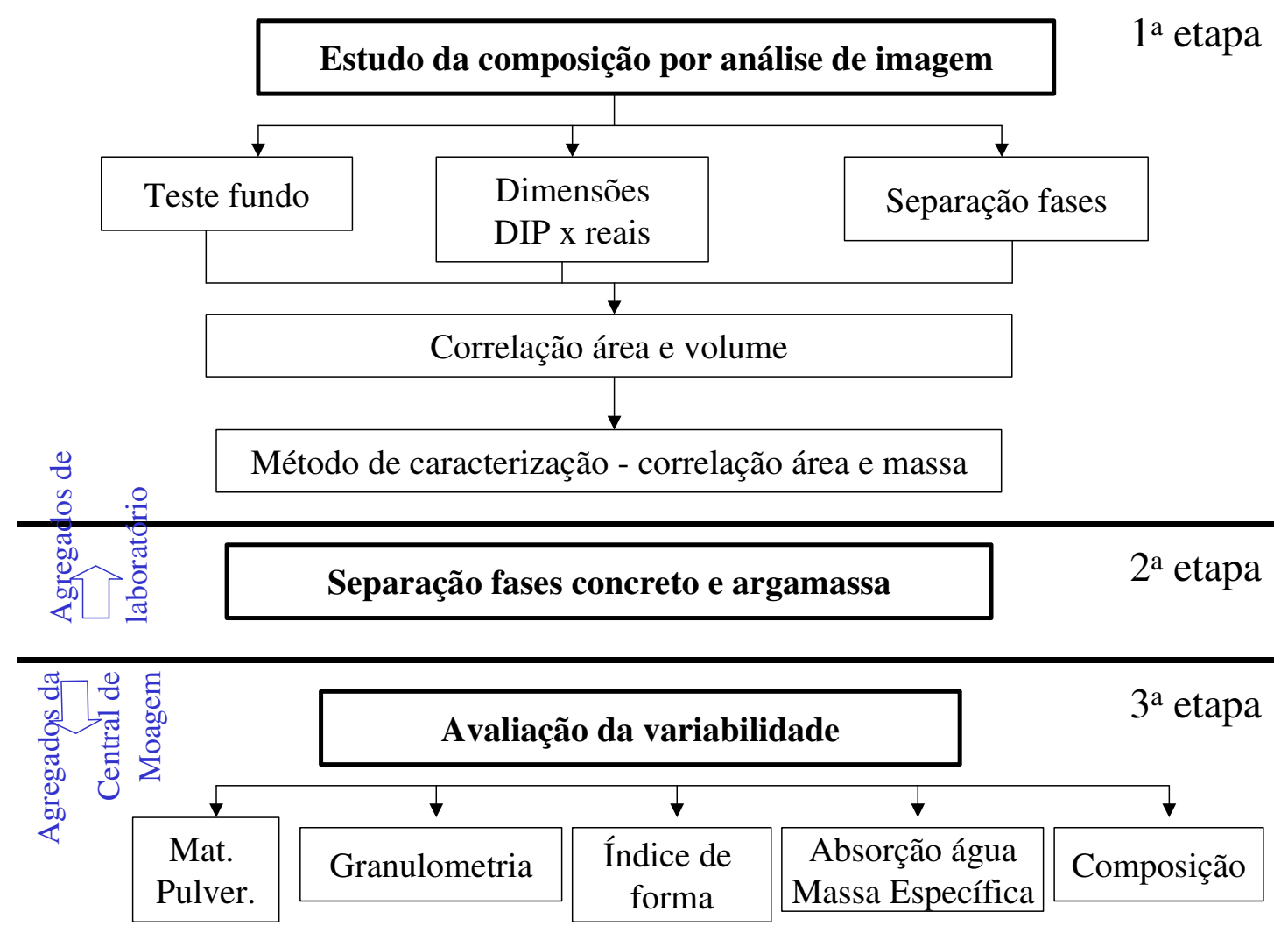

Figura 4.1 - Fluxograma do programa experimental. 


\subsection{PROGRAMA EXPERIMENTAL}

A Tabela 4.1 apresenta um resumo do programa experimental e as amostras utilizadas.

Tabela 4.1 - Resumo do programa experimental.

\begin{tabular}{|c|c|c|}
\hline Estudo & Ensaios/ Métodos & Amostras \\
\hline \multirow{5}{*}{$\begin{array}{l}\text { Estudo da composição por } \\
\text { análise de imagem }\end{array}$} & Teste de fundo padrão & $\begin{array}{l}4 \text { de laboratório } \\
\text { preta) } \\
1 \text { de lona } \\
\text { laranja). } \\
1 \text { de laboratório (lona } \\
\text { verde) }\end{array}$ \\
\hline & Precisão das dimensões por DIP ${ }^{1}$. & 4 de laboratório. \\
\hline & $\begin{array}{l}\text { Estudo da capacidade separação das fases } \\
\text { pelo programa de análise de imagem }\end{array}$ & 10 de laboratório. \\
\hline & $\begin{array}{l}\text { Correlação entre área e volume de agregados, } \\
\text { com ou sem orientação no plano }\end{array}$ & 20 de laboratório. \\
\hline & $\begin{array}{l}\text { Método de análise da composição por fases, } \\
\text { com relação entre área e massa }\end{array}$ & 8 de laboratório. \\
\hline $\begin{array}{l}\text { Uso da absorção de água e } \\
\text { massa específica para a } \\
\text { separação das fases concreto } \\
\text { e argamassa }\end{array}$ & Absorção de água e Massa Específica & 3 de laboratório. \\
\hline \multirow{6}{*}{$\begin{array}{l}\text { Avaliação da variabilidade } \\
\text { dos agregados graúdos de } \\
\text { RCD reciclados }\end{array}$} & Materiais pulverulentos & 36 da Central $^{2}$ \\
\hline & Composição granulométrica & 36 da Central \\
\hline & Índice de forma & 36 da Central \\
\hline & Absorção & 36 da Central \\
\hline & Massa Específica & 36 da Central \\
\hline & Composição por seleção manual & 36 da Central \\
\hline
\end{tabular}

\subsubsection{Estudo da composição por análise de imagem}

Este estudo tinha como objetivo determinar quantitativamente as fases da composição (em massa) de agregados graúdos de RCD reciclados a partir da análise de imagens planas dos grãos, propondo um método de caracterização pelo programa.

O programa empregado foi o Image Pro Plus 4.0. A câmara digital utilizada foi uma Kodak modelo DC220, sendo as fotos obtidas com resolução 1152 x 864 "pixels". Os agregados de RCD reciclados utilizados foram os obtidos em laboratório. Foram produzidas 6 composições misturando-se em massa agregados de concreto, argamassa e cerâmica. 
Inicialmente foram realizadas três etapas do estudo que tinha como objetivo encontrar as melhores formas de se obter a separação das fases empregando o programa: teste de fundo padrão, precisão da determinação das dimensões pelo programa e estudo da capacidade de separação das fases pelo programa.

\subsubsection{Teste de fundo padrão}

Esse teste foi realizado para a escolha de um fundo para as imagens de agregados, pois, no método de separação dos grãos por segmentação de cores, a coloração do fundo pode interferir e dificultar este processo de separação.

$\mathrm{Na}$ etapa de teste de fundo padrão foram analisadas 6 imagens (amostras): quatro imagens para a lona preta reflexiva, uma para a lona laranja e uma para a lona verde. Nas imagens com fundo padrão preto foi estudada a influência de uma fonte de iluminação e "flash" na separação dos grãos, sendo uma imagem sem os dois recursos, uma com os dois, e outras duas usando um recurso de cada vez. A partir do concluído em relação a esses recursos, foi definido o melhor, o qual seria empregado para avaliar os outros dois fundos.

Para o estudo de teste de fundo padrão, as lonas plásticas utilizadas como fundo para as imagens foram de 3 tipos: preta reflexiva, verde e laranja não reflexivas.

O estudo empregou o método detalhado no item 4.4.1.1.

\subsubsection{Precisão da determinação das dimensões por análise de imagem.}

O estudo teve como objetivo verificar a precisão com que o programa de análise de imagem determinava as dimensões de grãos selecionados em uma imagem, quando comparado com o mesmo grão medido por um paquímetro. Essa precisão é importante para uma possível separação dos grãos em função das suas características, como dimensão "Feret" por exemplo. Este estudo foi útil para viabilizar o estudo do item 4.2.1.3.

Realizaram-se medições em quatro grãos nas suas maiores distâncias entre dois pontos, por paquímetro e pelo programa, nos cantos extremos das imagens, identificados por superior esquerdo e direito e inferior esquerdo e direito, num total de 4 amostras. Foram utilizados somente agregados reciclados de concreto retidos na peneira normal de malha 12,7 mm, obtidos em laboratório.

O estudo empregou o método detalhado no item 4.4.1.1. 
4.2.1.3 Estudo da capacidade de separação das fases pelo programa de análise de imagem

O estudo teve como objetivo verificar a possibilidade de separação automática das três fases consideradas predominantes na composição dos agregados graúdos de RCD reciclados, através da análise de faixa de valores quantitativos de cores do padrão RGB, de dimensão Feret, de raio máximo, etc. Estes parâmetros são fornecidos pelo programa e podem classificar fases presentes da composição. Utilizaram-se agregados da amostra de laboratório.

Para caracterizar as fases, as imagens procuraram analisar as cinco composições descritas na Tabela 4.2.

Tabela 4.2 - Composições utilizadas no estudo de separação das fases.

\begin{tabular}{|c|c|c|c|}
\hline \multirow{2}{*}{ Composição } & \multicolumn{2}{|c|}{ Fases em percentual } & $\begin{array}{c}\text { Retidos em peneira } \\
\text { de malha }\end{array}$ \\
\hline I & Argamassa (45,5) & Cerâmica $(54,5)$ & $12,7 \mathrm{~mm}$ \\
\hline II & Argamassa (35,7) & Concreto $(64,3)$ & $12,7 \mathrm{~mm}$ \\
\hline III & Argamassa (55,2) & Cerâmica $(44,8)$ & $9,5 \mathrm{~mm}$ \\
\hline IV & Argamassa (44,2) & Concreto $(55,8)$ & $9,5 \mathrm{~mm}$ \\
\hline V & Argamassa (41,0) & Concreto $(59,0)$ & $6,25 \mathrm{~mm}$ \\
\hline
\end{tabular}

Na Tabela 4.3 existe a relação de parâmetros e definições que foi utilizada para o estudo, disponíveis no programa Image Pro Plus 4.0.

Tabela 4.3 - Parâmetros gerados pelo programa que podem servir de critério de separação de fases.

\begin{tabular}{|l|l|}
\hline Medida & Definição \\
\hline Densidade de componente de cor & $\begin{array}{l}\text { Indicação do valor da densidade do componente de cor um } \\
\text { objeto medido em RGB 24 bits. }\end{array}$ \\
\hline Diâmetro máximo & $\begin{array}{l}\text { Comprimento da maior linha que passa pelo centróide e por } \\
\text { dois pontos em cada perímetro do objeto. }\end{array}$ \\
\hline Raio mínimo & Mínima distância entre o centróide do objeto e perímetro. \\
\hline Esfericidade & $\begin{array}{l}\text { Relação dada pela fórmula: } \\
\text { Esf=(perímetro^2) / (4 x } \pi \text { x área) }\end{array}$ \\
\hline Dimensão fractal & $\begin{array}{l}\text { Classe de funções matemáticas desenvolvidas para descrever a } \\
\text { forma, por um número de processos físicos básicos.(LI et al., } \\
1993) .\end{array}$ \\
\hline Margination & $\begin{array}{l}\text { Distribuição da intensidade óptica entre o centro de um objeto } \\
\text { e sua fronteira. Desenvolvido pela Universidade de Delft, } \\
\text { departamento de Física Aplicada, nos Países Baixos. }\end{array}$ \\
\hline
\end{tabular}

O estudo empregou o método detalhado no item 4.4.1.1. 


\subsubsection{Correlações área x volume das fases}

Conforme revisão bibliográfica apresentada no terceiro capítulo, o percentual de área média dos diversos planos transversais a um volume em relação à área total é igual ao percentual de volume ocupado pelos agregados em relação ao volume total. Em última análise, integrando-se área das seções transversais de um sólido obtidas em espaçamentos infinitesimais $d x$, temos o próprio volume.

O objetivo deste estudo foi verificar a influência da orientação dos grãos no seu plano de maiores dimensões na correlação entre área e volume. Esta orientação é mais importante quanto mais lamelar for o grão, caso em que se enquadram os agregados de RCD que são constituídos de fases que podem ter índices de lamelaridade diferentes.

\subsection{Com orientação dos grãos}

O estudo tinha como objetivo verificar se os grãos de agregados graúdos de RCD reciclados apresentavam planos de orientação preferencial, quando dispostos numa superfície plana, e se seria possível obter uma boa correlação entre a área e volume.

Os agregados de laboratório foram compostos em três fases com proporções conhecidas que foram dispostas e misturadas na área selecionada, tomando-se o cuidado de evitar a sobreposição e conjunção de grãos. O estudo empregou o método detalhado no item 4.4.1.1. Os valores de massa específica das três fases foram determinados, conforme método descrito no item 4.4.4.5.

A Tabela 4.4 apresenta a composição utilizada no estudo, os valores de massa específica e as proporções volumétricas entre as fases da composição. Foram realizadas 14 imagens (amostras) que continha 4,8 quilos de agregados graúdos.

\section{Tabela 4.4 - Dados da composição para o estudo de correlação entre \% A e \%V com orientação das camadas.}

\begin{tabular}{|c|c|c|c|c|}
\hline Fases & Concreto & Argamassa & Cerâmica & Total \\
\hline Massa (kg) & 2,025 & 0,986 & 1,786 & 4,797 \\
\hline Massa específica $\left(\mathrm{kg} / \mathrm{m}^{3}\right)$ & 2,28 & 1,8 & 2,21 & \\
\hline Volume $\left(\mathrm{m}^{3}\right)$ & 0,888 & 0,548 & 0,808 & \\
\hline$\%$ das fases (em volume) & 40 & 24 & 36 & 100 \\
\hline
\end{tabular}




\subsection{Sem orientação dos grãos}

Considerando-se que a estabilização dos agregados, quando distribuídos em uma área, pode levar a uma orientação preferencial das partículas em um determinado plano, tentou-se neutralizar essa orientação distribuindo-se os grãos dos agregados numa superfície irregular.

Neste estudo, utilizaram-se somente os agregados reciclados de concreto em razão da facilidade de separação dos grãos pelo padrão RGB. O objetivo foi fornecer dados da aplicabilidade para um estudo com amostras com as três fases principais presentes (concreto, argamassa e cerâmica), procurando a correlação entre área e massa das fases.

Foram realizadas 6 imagens (amostras) com 4,96 quilos de agregados. Tomouse cuidado para que os filmes de polietileno preto e azul não interferissem na orientação dos grãos, sendo delgados o suficiente para que se acomodassem nos vazios presentes entre as camadas. Apesar das conclusões de teste de fundo padrão, expostas no capítulo 5 , indicarem que seria melhor a utilização de filmes não reflexivos, os filmes utilizados foram reflexivos em função da facilidade de aquisição. Entretanto, não se utilizou flash, apenas uma fonte de iluminação comum com luz amarela.

Como a fase da composição era única, obteve-se o volume percentual da fase pela divisão entre volume de grãos (agregados sem vazios) e volume total (agregados com vazios), expresso em porcentagem.

O volume dos grãos (sem vazios) foi obtido pela relação entre a massa do material das camadas dividida pela massa específica do agregado de concreto (determinada no item 4.2.1.4.1). O volume total (grãos com vazios) foi obtido pelas dimensões do recipiente multiplicado pela altura total das camadas, medida obtida no laboratório.

A (eq.4.1) e (eq.4.2) mostram os valores obtidos para o volume total e volume dos grãos.

$$
\begin{gathered}
V_{\text {grãos }}=\frac{m}{\delta}=\frac{4962 \mathrm{~g}}{2,28 \mathrm{~g} / \mathrm{cm}^{3}}=2.176,316 \mathrm{~cm}^{3} \text { (eq.4.1) } \\
\text { Vtotal }=(34 \times 23,3 \times 6)=4.753,2 \mathrm{~cm} 3 \text { (eq.4.2) }
\end{gathered}
$$

O volume percentual dos grãos é $45,79 \%$, resultado obtido pela divisão da equação 4.1 pela equação 4.2 , expresso em porcentagem. 
O volume percentual dos grãos foi comparado com a área percentual dos grãos, obtida pela divisão da área dos grãos na imagem pela área total da camada, expressa em porcentagem.

O estudo empregou o método detalhado no item 4.4.1.2.

\subsubsection{Correlação área e massa das fases}

Este estudo teve como objetivo aplicar a correlação entre a área e o volume e determinar a correlação entre a área e a massa dos agregados graúdos de RCD reciclados.

Aplicou-se a correlação entre percentual de área e percentual de volume sem orientação dos grãos nas camadas, com três fases presentes, determinando as massas específicas das fases da composição (determinada no item 4.2.1.4.1) para a conversão da relação em massa. Definiu-se também um procedimento para a separação das fases da composição pelo processo de análise de imagem, que será apresentado no capítulo 5.

Foram utilizados os agregados produzidos em laboratório e criou-se uma composição conhecida entre as três fases (concreto, argamassa e cerâmica), medindo-se a massa de cada fase isoladamente. Essas três fases foram misturadas e dispostas em camadas, tendo o cuidado de evitar a sobreposição e conjunção de grãos. Foram realizadas 8 imagens (amostras) com um total em massa de 4,8 Kg.

O estudo empregou o método detalhado no item 4.4.1.2.

A Tabela 4.5 mostra a composição definida em laboratório para o estudo, com suas massas determinadas. Na seqüência, as fases foram misturadas aleatoriamente e realizaram-se as imagens das camadas.

\section{Tabela 4.5 - Composição das fases da amostra de agregados para correlação entre $\%$ área e \% massa.}

\begin{tabular}{|c|c|c|c|}
\hline & Concreto & Argamassa & Cerâmica \\
\hline Massa (Kg) & 2,025 & 0,986 & 1,786 \\
\hline \% em massa por fases & 42,22 & 20,55 & 37,23 \\
\hline
\end{tabular}

\subsubsection{Uso de absorção de água e massa específica para a separação das fases concreto e argamassa.}

Conforme discutido no item 3.1, considera-se que o método de avaliação da composição desses agregados por seleção manual não é eficiente para separar as fases "concretos" e "argamassas". O método proposto por ZORDAN (1997) considera como 
"concreto" os grãos que apresentam visualmente a presença de argamassa e de agregado graúdo natural. Porém podem existir grãos da fase "concreto", como grãos provenientes da britagem de um contrapiso, que são mais porosos e absorvem mais água que concretos convencionais/provenientes da estrutura, comportando-se como argamassa em relação às propriedades absorção de água e massa específica.

Pode-se diferenciar fases "concreto" de "argamassa" aplicando as seguintes equações, baseadas nas propriedades de absorção de água e massa específica.

$$
\begin{gathered}
\text { Acon } / \arg =\% \text { con } \times \text { Acon }+\% \arg \times \mathrm{A} \arg \\
\delta \text { con } / \arg =\% \text { con } \times \delta \text { con }+\% \arg \times \delta \text { con } \\
\% \text { eq. } 4.4) \\
\text { con }+\% \arg =100 \quad(\text { eq.4.5) }
\end{gathered}
$$

sendo:

Acon/arg - absorção de água da fase conjunta de concreto e argamassa.

$\%$ con - percentual em massa da fase concreto.

A con - absorção de água média da fase concreto.

$\%$ arg - percentual em massa da fase argamassa.

A arg - absorção de água média da fase argamassa.

$\delta$ con/arg - massa específica da fase conjunta de concreto e argamassa.

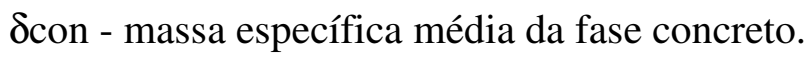

Sarg - massa específica média da fase argamassa.

Este procedimento pode ser adotado com base nas seguintes premissas:

a) os valores de massa específica e absorção de água do concreto e da argamassa são muito diferentes (Figura 2.11), nem mesmo os valores extremos dos dados analisados se sobrepõem. Os dados sugerem ser possível adotar valores médios de massa específica seca de $2,5 \mathrm{Kg} / \mathrm{dm}^{3}$ para a fase "concreto" e $1,75 \mathrm{Kg} / \mathrm{dm}^{3}$ de agregados reciclados da fase "argamassa";

b) as duas propriedades, representadas pelas equações 4.3 e 4.4 , são variáveis dependentes. Assim, pode-se encontrar solução para as variáveis a partir do sistema linear. A equação 4.5 pode também ser utilizada, pois necessariamente a soma das fases deve totalizar $100 \%$.

Assim, de posse dos valores médios de absorção de água e de massa específica é possível montar um sistema de duas equações e duas incógnitas para obter os percentuais de cada fase. 
Para se validar a utilização do sistema de equações para a determinação do teor das fases concreto e argamassa na composição, foram criadas três composições, misturando, em massa, percentuais conhecidos das fases concreto e argamassa como agregados graúdos de RCD reciclados, conforme a Tabela 4.6. Procurou-se criar composições com predominância de cada uma das fases e uma composição com porcentagens médias das fases.

Tabela 4.6 - Composições elaboradas em laboratório para aprimoramento da análise de composição por separação manual.

\begin{tabular}{|c|c|c|}
\hline \multicolumn{3}{|c|}{ AMOSTRA A } \\
\hline Composição & Massa (Kg) & Teor (\% em massa) \\
\hline Concreto & 1,329 & 84,3 \\
\hline Argamassa & 0,243 & 15,7 \\
\hline Total & 1,572 & 100,0 \\
\hline \multicolumn{3}{|c|}{ AMOSTRA B } \\
\hline Composição & Massa (Kg) & Teor (\% em massa) \\
\hline Concreto & 0,750 & 50 \\
\hline Argamassa & 0,750 & 50 \\
\hline Total & 1,500 & 100 \\
\hline Composição & AMOSTRA C & Teor (\% em massa) \\
\hline Concreto & Massa (Kg) & 28,3 \\
\hline Argamassa & 0,425 & 71,7 \\
\hline Total & 1,075 & 100 \\
\hline
\end{tabular}

Compararam-se os percentuais de concreto e argamassa obtidos pelo sistema de equações com os elaborados em laboratório, aplicando-se o modelo teórico de correlação entre as propriedades de absorção de água e massa específica seca (Figura 2.11).

\subsubsection{Avaliação da variabilidade dos agregados graúdos de $R C D$ reciclados}

O objetivo desta etapa do programa experimental foi avaliar a variabilidade de agregados graúdos de RCD reciclados obtidos de uma Central de Moagem segundo sua composição dos agregados de RCD reciclados e algumas propriedades físicas.

As propriedades avaliadas seguiram um procedimento que tinha por objetivo criar uma seqüência ótima no laboratório, com o intuito de minimizar o tempo e os fluxos internos, conforme ilustra o fluxograma da Figura 4.2. 


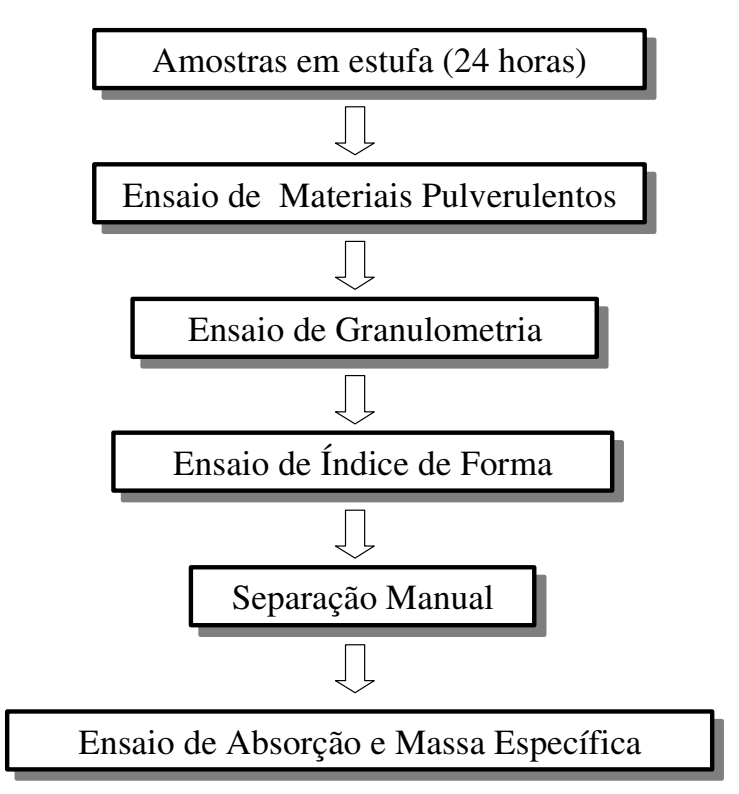

\section{Figura 4.2 - Fluxograma dos ensaios realizados no laboratório do Centro de Pesquisa e Desenvolvimento da Construção Civil.}

Os ensaios se encaixam em procedimentos operacionais subseqüentes, pois percorrem as mesmas etapas, como as apresentadas a seguir:

a) o ensaio de materiais pulverulentos é necessário para a determinação da granulometria, do índice de forma, do estudo da composição por separação manual, da absorção de água e da massa específica. Assim, é o primeiro ensaio a ser realizado, pois todos os outros exigem a retirada do material pulverulento para as suas realizações;

b) na seqüência, os agregados são caracterizados pelo ensaio de composição por separação manual (item 4.4.4);

c) finalizando, com as fases da composição separadas, as absorções das diferentes fases são determinadas, bem como suas massas específicas.

Os métodos de caracterização empregados foram os detalhados no item 4.4.4.

\subsection{AMOSTRAS UTILIZADAS}

\subsubsection{Amostras de agregados graúdos de $R C D$ reciclados em laboratório}

As amostras de laboratório foram compostas pela britagem artificial separada (a) de um concreto convencional de resistência aproximada de $25 \mathrm{MPa}$ para o fornecimento da fase "concreto"; (b) e de uma parede de alvenaria composta de blocos 
cerâmicos e argamassa de assentamento para o fornecimento das fases "cerâmica" e "argamassa". O britador utilizado foi um de mandíbula, do laboratório de Engenharia de Minas da Escola Politécnica da Universidade de São Paulo.

As fases minerais concreto, argamassa e cerâmica foram consideradas predominantes na composição dos agregados graúdos de RCD reciclados, baseado em dados de variabilidade de ZORDAN (1997).

Esses agregados das fases cerâmica e argamassa foram separados manualmente e estocados separados. Com os grãos de cada fase separados, composições de amostras com esses agregados foram criadas dependendo da necessidade do estudo. Com isso, obtiveram-se composições conhecidas dos agregados em função das fases presentes.

\subsubsection{Amostras de agregados graúdos de RCD reciclados na Central de Moagem}

Essas amostras foram empregadas no estudo da variabilidade de agregados graúdos de RCD reciclados e tiveram que seguir procedimento de coleta para garantir uma representatividade estatística do lote desses agregados, que será detalhada a seguir.

As amostras foram obtidas pela central de processamento de RCD da Prefeitura de Santo André, pertencente ao órgão NIPP (Núcleo de Inovação de Políticas Públicas), situada na Rua Tamarutaca, número 175. As amostras foram coletadas durante 12 dias, distribuídas dentro do período de um mês. Nesta amostragem não se avalia a sazonalidade anual na geração de RCD e nem a variação regional de uma cidade.

A central de moagem operava três dias por semana, tendo sido coletadas em 12 dias três amostras diárias, totalizando 36 amostras.

A Figura 4.3 mostra o equipamento de britagem por impacto utilizando na central de reciclagem onde foram coletadas as amostras. 


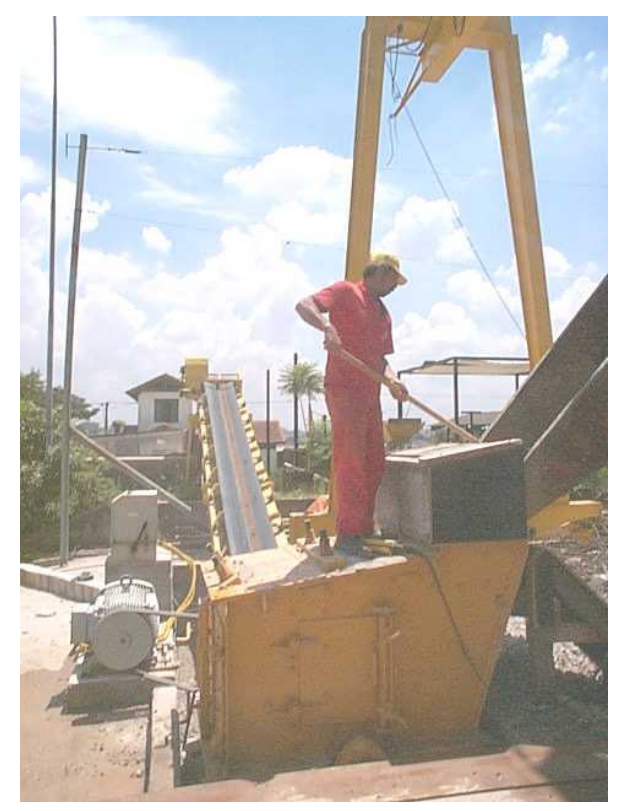

Figura 4.3 - Equipamento empregado para a britagem das amostras.

A seguir, a Figura 4.4 ilustra por meio de um fluxograma o procedimento operacional realizado em Santo André, bem como a formação das amostras representativas 5 .
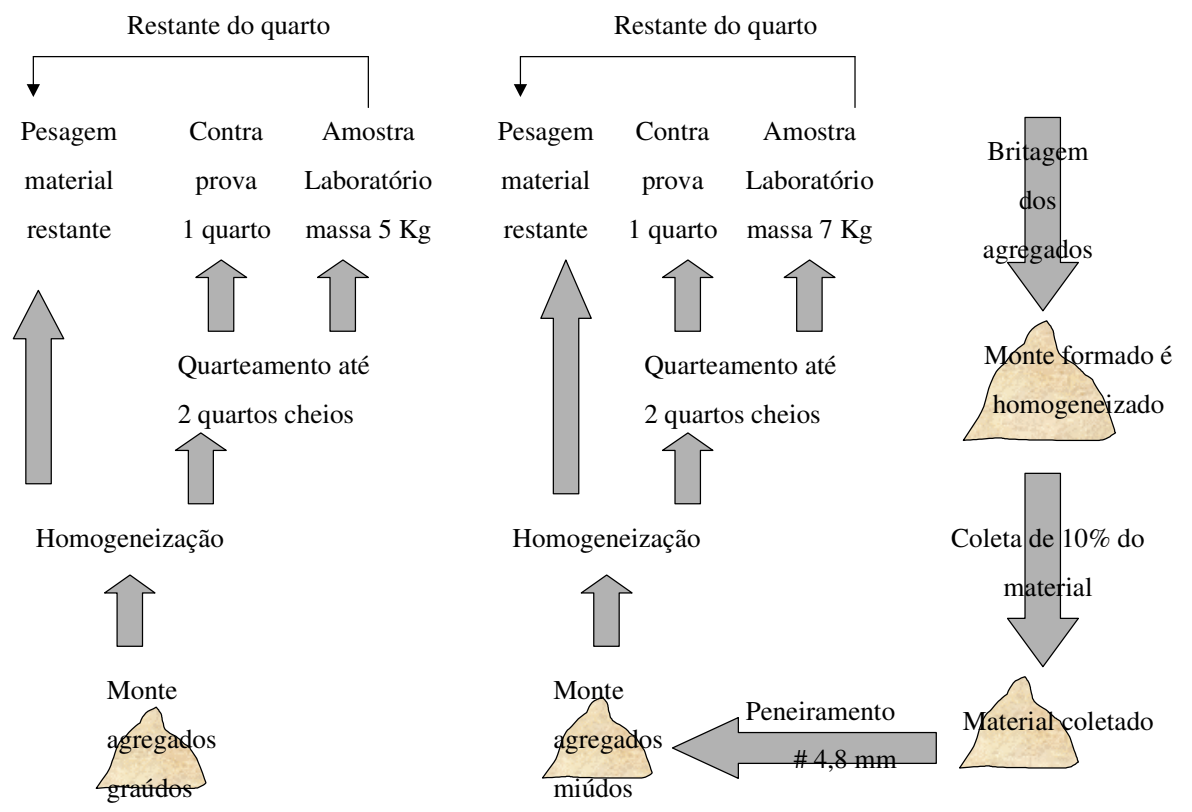

Figura 4.4 - Fluxograma operacional de Santo André.

${ }^{5}$ Os agregados graúdos e miúdos são separados pela peneira de abertura de malha 4,8 mm, conforme NBR 7217 (ABNT, 1987). 
A Figura 4.5 mostra o peneirador mecânico adaptado na central para realizar o peneiramento das frações das amostras.

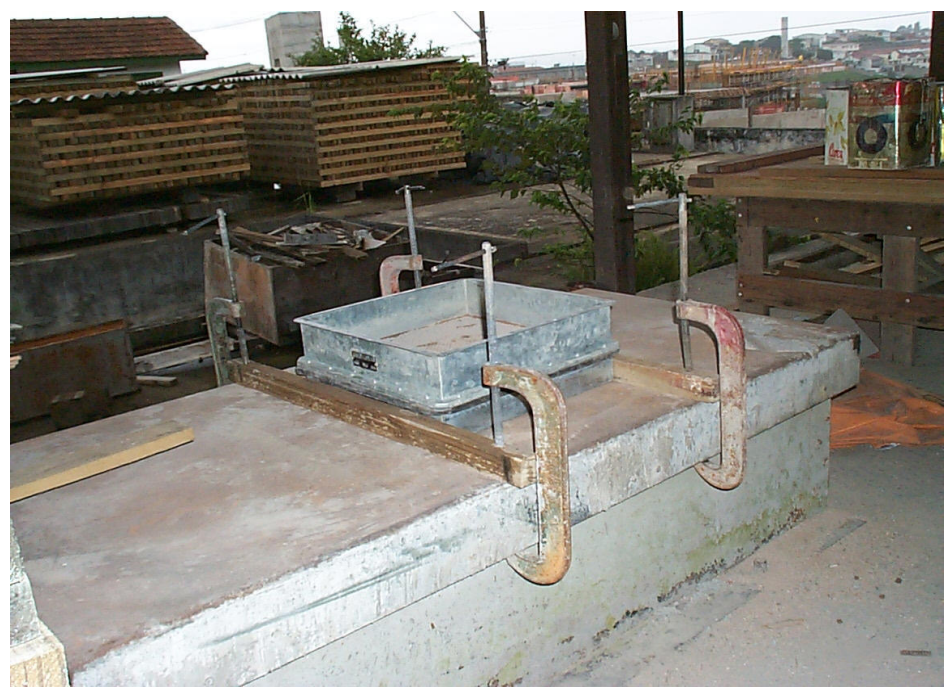

Figura 4.5 - Peneirador mecânico adaptado na Central de Moagem.

A Figura 4.6 mostra os montes obtidos pela separação das frações de agregados miúdos e graúdos da amostra.

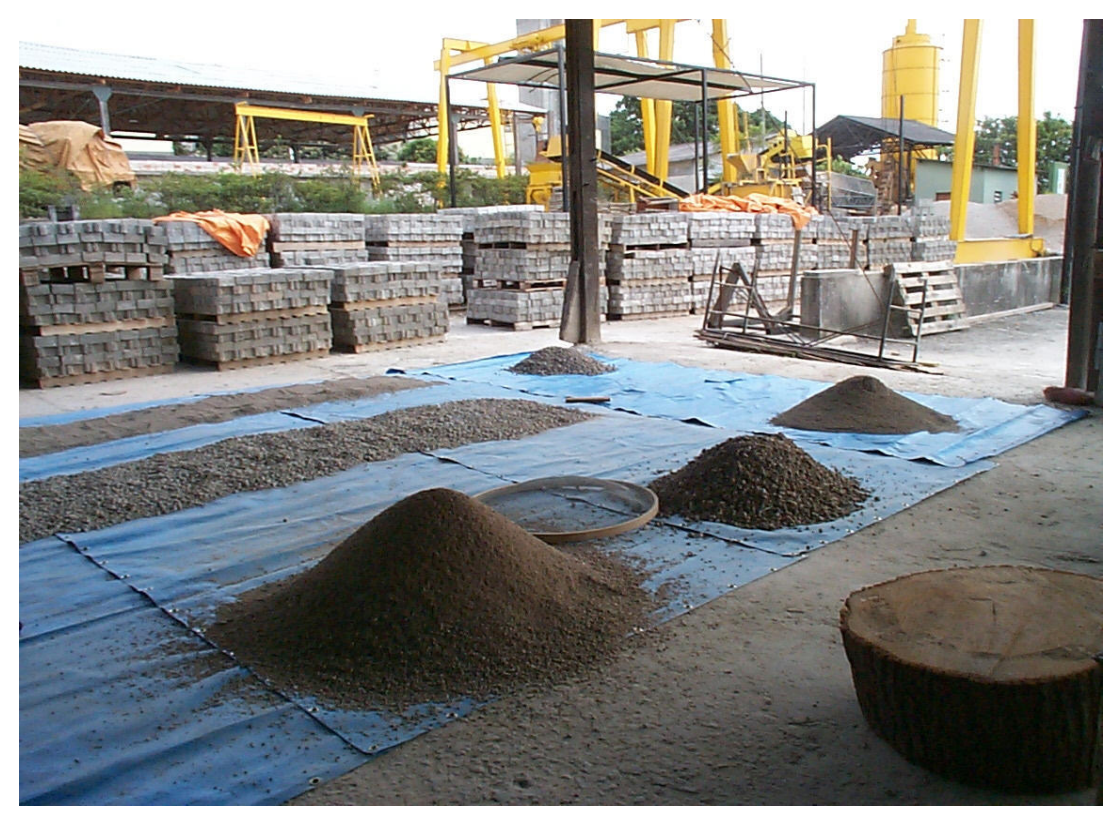

Figura 4.6 - Separação das frações de agregados graúdos e miúdos da amostra.

A coleta e definição das amostras obedeceram o método detalhado no item 4.4.3. 


\subsection{MÉTODOS}

\subsubsection{Estudo da composição por análise de imagem}

\subsubsection{Método de análise de imagem com orientação dos grãos}

Este método foi utilizado nos estudos preliminares do estudo da composição por análise de imagem, como teste de fundo padrão, precisão da determinação das dimensões por análise de imagem e estudo da capacidade de separação das fases pelo programa de análise de imagem. Em seguida, o método foi aplicado para o estudo de correlação entre área e volume, com orientação dos grãos no plano.

O método consiste na obtenção de imagens dos agregados pela delimitação na lona de uma área de $(33$ x $20 \mathrm{~cm})$, de tal forma que a câmara digital ficasse em zoom máximo.

A Figura 4.7 ilustra a realização do teste.

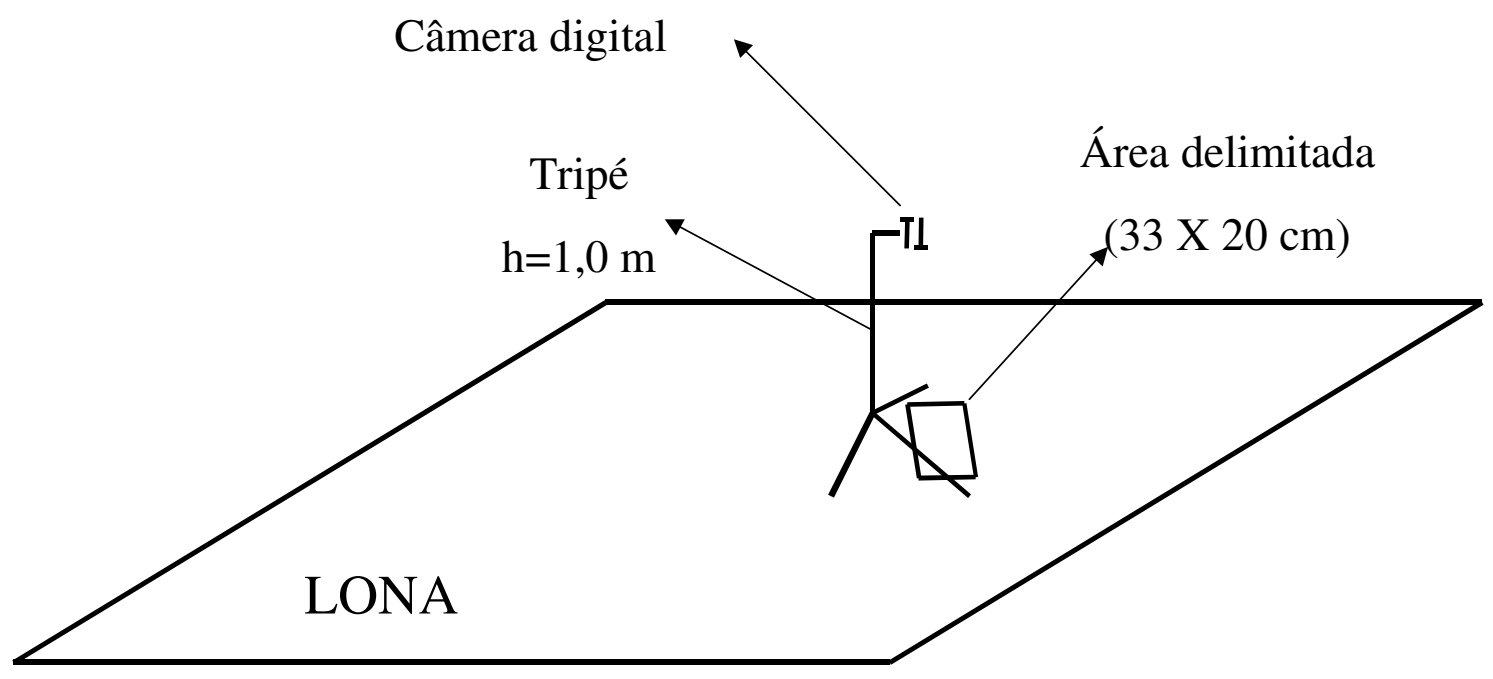

Figura 4.7 - Ilustração do procedimento do teste de fundo padrão.

No estudo de teste de fundo padrão, o método de análise foi por segmentação de cores, sendo utilizado padrão RGB.

No estudo da capacidade de separação das fases pelo programa de análise de imagem, foi necessária a separação das fases da composição para análise dos parâmetros citados. A separação das fases presentes na composição foi realizada pela observação da imagem, sendo os grãos das fases selecionados por área de interesse, com 
as linhas externas ${ }^{6}$ dos grãos geradas por processo não automático do programa em questão.

\subsubsection{Método de análise de imagem sem orientação dos grãos}

Este método foi utilizado para o estudo de correlação entre área e volume sem orientação dos grãos e para o de correlação entre área e massa.

Os agregados foram dispostos em diferentes camadas, separadas por filme fino de polietileno. Com esse mecanismo, era possível criar um fundo, evitando a sobreposição de camadas, em que as áreas inferiores poderiam ser computadas na imagem posterior durante a análise de imagem pelo programa.

Para o estudo de correlação entre área e volume sem orientação dos grãos foi utilizado um recipiente com seções retas, sendo o lado superior vazado, três lados laterais de vidro, e o lado restante e o fundo de madeira. O recipiente possuía, portanto, a forma de um paralelepípedo com área de 34,0 x 23,3 cm. A área dos grãos foi selecionada pelo método da segmentação de cores.

A Figura 4.8 ilustra o procedimento adotado.

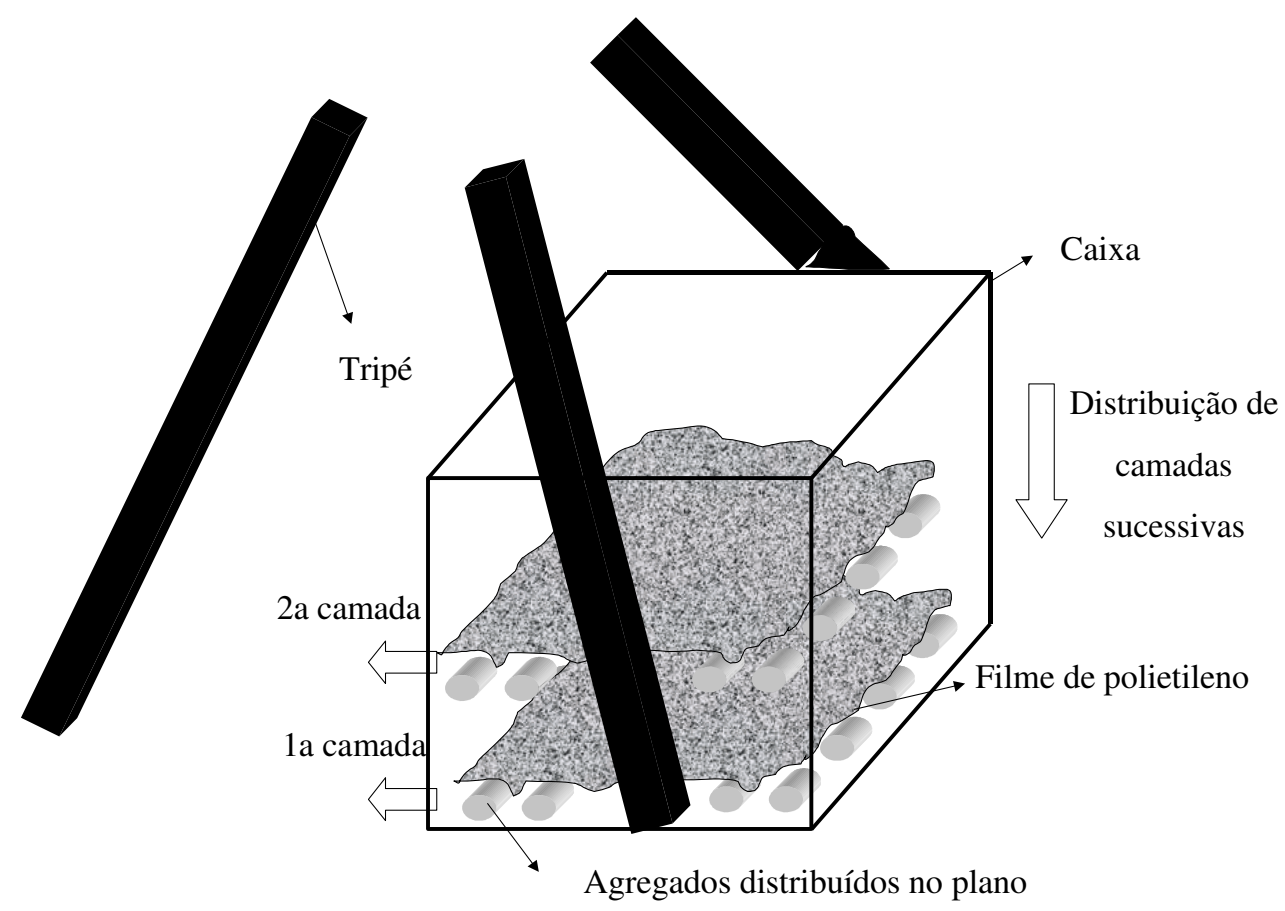

Figura 4.8 - Procedimento para elaboração das correlações de área e volume, sem orientação dos grãos no plano.

${ }^{6}$ O programa é capaz de traçar as linhas de contorno dos grãos ou da área de interesse que se deseja analisar. 
No estudo de correlação entre área e massa, o recipiente foi modificado em razão da facilidade de caracterização. O recipiente tinha seção $(31,5 \times 31,5 \mathrm{~cm})$. Destaca-se que este estudo apenas utilizou filme de polietileno preto reflexivo para a separação de camadas de agregados distribuídas no plano.

\subsubsection{Uso da absorção de água e massa específica para a separação das fases concreto e argamassa}

O método consiste em empregar as equações $4.3,4.4$ e 4.5 utilizando valores médios de absorção de água e massa específica determinados por um gráfico detalhado na figura 2.11 e discutido no capítulo 3. Os valores de absorção e massa específica da fase conjunta foram obtidos segundo a NBR 9937 (ABNT, 1987).

\subsubsection{Método de coleta das amostras de agregados graúdos de RCD reciclados da Central de Moagem}

\subsubsection{Definição das amostras.}

Para os agregados, é fundamental a definição da amostragem. A amostra é uma porção estatística representativa da população, ou seja, detém / possui as mesmas propriedades que o universo (JONES, 1987).

É difícil definir amostras de rochas britadas que apresentam variação de tamanho, forma, massa e composição das partículas. Erros estatísticos são sempre previsíveis nessas amostras (JONES, 1987).

O mesmo autor considera redução por quarteamento a melhor prática para retirada de pequenas quantidades de materiais de uma pilha crescente de partículas minerais.

A coleta das amostras obedeceu às normas NBR 10.007 (ABNT, 1987), NBR 7216 (ABNT, 1987) e NBR 9941 (ABNT, 1987), sendo as duas primeiras normas para a retirada de amostragem de resíduos/agregados e a última sobre a redução de amostras de campo.

A NBR 7216 (ABNT, 1987) define lote de agregado como "quantidade definida de agregado produzido sob condições presumidamente uniformes. ...não devendo ultrapassar $300 \mathrm{~m}^{3}$ de agregado de mesma origem ou, nos processos contínuos, a quantidade correspondente a 12 h ininterruptas de produção.". 
As condições encontradas na central de moagem foram de processamento de 3 $\mathrm{m}^{3}$ de RCD dia, gerando um volume aproximado de agregados de $70 \%$ desse valor, perfazendo um total de $2,1 \mathrm{~m}^{3}$ de agregados reciclados de RCD por dia como lote. ${ }^{7}$

A peneira na saída do britador possuía grãos de agregados de RCD reciclados com dimensões inferiores a $12,7 \mathrm{~mm}$.

Durante as quatro horas de produção diária foi possível realizar a retirada de 3 amostras horárias, em razão da necessidade de alimentar o equipamento com o material para a britagem.

O lote de agregados foi reduzido a uma amostra de campo, que é definida pela NBR 7216 (ABNT, 1987) como "porção representativa de um lote de agregado, coletada nas condições prescritas nesta norma, seja de fonte de produção, armazenamento ou transporte".

A amostra de campo foi reduzida a um valor de $10 \%$, sendo considerada representativa do total do lote, procedimento detalhado no item 4.4.3.2. O lote de $2,1 \mathrm{~m}^{3}$ de agregados, dividido em 3 horas diárias de produção, equivale a $700 \mathrm{dm}^{3}$ por cada hora de coleta. Com os $10 \%$ de redução, as amostras de campo foram de $70 \mathrm{dm}^{3} \mathrm{em}$ cada hora de coleta, que equivale a 4 latas de 18 litros na saída da produção dos agregados.

\subsubsection{Procedimentos de coleta das amostras}

Para a coleta das amostras dos agregados ficaram definidos os seguintes procedimentos:

$>$ homogeneização de todo o lote com enxada, deixando que a distribuição de partículas de areia e pedrisco ficasse visivelmente semelhante em todos os pontos do lote;

$>$ retirada dos agregados com pá, em mais de 7 pontos por lata de 18 litros, alternados de um lado para outro diagonalmente, de forma aleatória, desde a crista até a base, em seqüência não repetitiva;

retirada de 4 latas/horárias de 18 litros a cada hora produzida, para formar a amostra;

${ }^{7}$ Dados fornecidos pelo Arquiteto Gilson Lameira e o Engenheiro Marcos Tamai, responsáveis operacionais pela Central de Moagem de Entulho da Prefeitura de Santo André, situada no NIPP. 
repetição desse procedimento durante três horas diárias.

Esse procedimento foi definido com base nas normas NBR 7216 ( ABNT, 1987) e NBR 10007 (ABNT, 1987), a primeira para a coleta de amostras de agregados e a segunda para a coleta de amostras de resíduos. Desta forma, uniram-se os procedimentos das duas normas em um procedimento único.

Pela NBR 10007 (ABNT, 1987) a amostragem em montes e pilhas de resíduos deve ser feita em pelo menos três pontos da pilha (topo, meio e base). Pela NBR 7216 (ABNT, 1987), a amostra de campo deve ser formada por pelo menos 20 amostras parciais com volume de $40 \mathrm{dm}^{3}$, coletadas alternadamente de um lado e de outro (desde a crista até a base da pilha).

\subsubsection{Homogeneização e redução das amostras}

A homogeneização dos montes de agregados, obtida pelo peneiramento mecânico, foi realizada com base na norma brasileira NBR 9941 (ABNT, 1987). revirando-se o material do monte por completo três vezes. A Figura 4.9 ilustra tal procedimento.

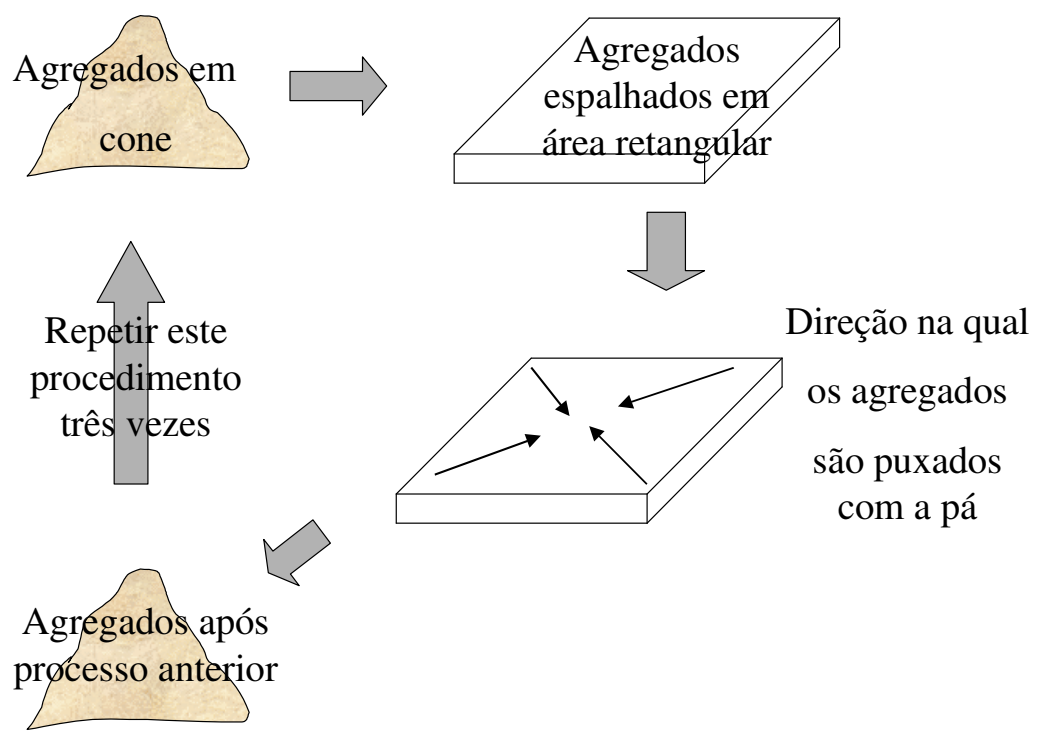

Figura 4.9 - Procedimento para a homogeneização dos montes de agregados.

A redução de amostras para laboratório também seguiu a mesma norma, sendo utilizado o mecanismo de quarteamento mecânico. Uma parte do quarto era guardada como contra-prova das amostras de laboratório e a outra parte do quarto fornecia a amostra de laboratório com uma massa de cinco quilos. O restante deste quarto e o resto da amostra eram pesados e depois descartados. 
O mesmo procedimento foi realizado para os agregados miúdos com diferença apenas na massa da amostra de laboratório que, neste caso era de sete quilos. A contraprova dos agregados miúdos não foi levada para laboratório, uma vez que a massa de material necessário para a caracterização dos miúdos é muito menor, sendo os sete quilos suficientes para as repetições necessárias.

Para os agregados graúdos e miúdos não foram realizadas pesagens dos quartos, sendo consideradas apenas as relações de volume nos mesmos.

Todas as amostras foram encaminhadas ao Centro de Pesquisa e Desenvolvimento de Construção Civil, do Departamento de Engenharia de Construção Civil da Escola Politécnica da Universidade de São Paulo.

\subsubsection{Avaliação da variabilidade dos agregados de $R C D$ reciclados}

\subsubsection{Ensaio de materiais pulverulentos}

Esse ensaio foi realizado pela norma NBR 7219 (ABNT, 1987). É considerado material pulverulento todo o material passante na malha de peneira $0,075 \mathrm{~mm}$, incluindo materiais solúveis em água. A massa mínima por amostra do ensaio é de $5 \mathrm{Kg}$.

\subsubsection{Distribuição granulométrica}

O ensaio de distribuição granulométrica foi realizado de acordo com a NBR 7217 (ABNT, 1987). A massa mínima por amostra é de $5 \mathrm{Kg}$, para dimensão máxima característica de agregados entre $9,5 \mathrm{~mm}$ e $25,0 \mathrm{~mm}$.

\subsubsection{Ensaio de índice de forma}

O ensaio de índice de forma foi realizado de acordo com a norma NBR 7809 (ABNT, 1983). Esta norma define o índice de forma como sendo a relação entre o comprimento e a espessura dos grãos dos agregados, ponderada pela quantidade de grãos retidos em cada fração granulométrica.

A massa de agregados analisada foi de $5 \mathrm{Kg}$, embora a norma recomende $8 \mathrm{Kg}$, em razão da conformidade com a massa da amostra utilizada nos outros ensaios da variabilidade. Foram medidos cem grãos, embora a norma recomende duzentos, em razão da extensão dos procedimentos de laboratório. Todos os grãos analisados foram os retidos em peneira de abertura de malha $9,5 \mathrm{~mm}$, pois as porcentagens passantes a 
partir desta malha devem ser desprezadas e todos os retidos em peneiras de malhas maiores não possuíam porcentagem retida individual maior que cinco por cento.

Os grãos foram medidos com paquímetro em três eixos, sendo considerados os valores de maior e menor dimensão.

\subsubsection{Separação manual das fases}

O método empregado foi o mesmo proposto por ZORDAN (1997) com algumas adaptações que serão apresentadas a seguir. O método consiste em realizar uma inspeção visual na amostra previamente pesada, separando manualmente as fases. Ao final, as diferentes fases são pesadas. As relações entre massas parciais e massa total da amostra fornecem o valor percentual da fase.

Em razão da dificuldade de separação manual das fases concreto e argamassa nas amostras obtidas em Santo André, foram utilizadas as propriedades de absorção de água e massa específica para a separação das fases. Conforme proposto no item 4.2.2, o sistema linear formado pelas equações 4.3 e 4.4 forneceu a solução de percentuais para as fases.

Os resultados do experimento do item 4.2.2 indicaram viabilidade na aplicação dessas propriedades para a determinação dos percentuais das fases concreto e argamassa, conforme o item 5.2 do capítulo 5 .

Por este item, pode-se concluir que a solução pelo sistema de equações apresenta erros. Porém, fixando o valor da fase argamassa obtido pelo sistema de equações lineares e aplicando-se a equação 4.5, calcula-se o teor da fase concreto. Por este procedimento, os erros do experimento 4.2.2 ficaram em torno de $10 \%$, sendo considerado tolerável.

Desta forma, o procedimento adotado para a análise da composição por separação manual das fases foi a seleção por inspeção visual das seguintes fases:

a) concreto / argamassa: toda fase que contenha material aglutinante (cimento, cal) com a presença de areia ou brita na maior parte do grão;

b) rochas: toda fase que contenha fragmentos de rochas naturais na maior parte do grão;

c) cerâmica: toda fase que contenha material cerâmico, com superfície polida ou não na maior parte do grão; 
d) materiais betuminosos: toda fase que contenha material betuminoso na maior parte do grão;

e) outros: toda fase que não se ajuste às classificações anteriores.

Em seguida, a fase concreto/argamassa foi separada com o uso das propriedades absorção de água e massa específica, conforme mencionado nos parágrafos anteriores.

\subsubsection{Ensaio de absorção de água e massa específica}

O ensaio utilizado foi o da NBR 9937 (ABNT, 1987). Não foram determinados valores de massa mínima para a realização dos ensaios, uma vez que estes ensaios eram realizados nas fases separadas da amostra, obtidas pelo item 4.4.4.4. Para se ter uma referência, a massa mínima da amostra para agregados com dimensão máxima de 12,5 $\mathrm{mm}$ deve ser 2,0 $\mathrm{Kg}$ pela norma.

\subsection{Análise estatística.}

Alguns resultados do estudo de aplicação da técnica de análise de imagem para avaliação da composição de agregados graúdos de RCD reciclados utilizaram ferramentas estatísticas, como distribuição normal, probabilidades, variância e desvio padrão. Em alguns casos utilizou-se uma avaliação de sobreposição de valores, a partir de valores de limite superior e inferior, média e desvio padrões (VUOLO, 1992; WAENY, 1992; DEVORE, 1995; LAPPONI, 1997).

Os resultados do estudo de variabilidade dos agregados graúdos de RCD reciclados utilizaram, além desses conceitos empregados anteriormente, os conceitos de regressão linear, regressão linear múltipla, testes de normalidade e retirada de valores espúrios. Os dados foram apresentados em histogramas e gráfico de boxes.

Entende-se por regressão linear um diagrama de dispersão que sugere a existência de uma relação funcional entre duas variáveis. Utiliza o procedimento de mínimos quadrados, em que a reta torna mínima a soma dos quadrados das distâncias da reta aos pontos experimentais (COSTA NETO, 1977).

Podem ser fornecidos dois coeficientes desta regressão, o coeficiente de determinação e o de correlação. O coeficiente de determinação é igual ao quadrado do coeficiente de correlação. É, na verdade, o coeficiente de correlação que mede o grau de associação linear entre duas variáveis (LAPPONI, 1997). 
A diferença da regressão linear múltipla para a regressão linear simples é que esta regressão possui duas ou mais variáveis independentes (COSTA NETO, 1977).

A verificação da normalidade é realizada por um teste chamado SHAPIROWILK, demonstrado em WAENY (1992). Este teste consiste em criar uma hipótese em que a probabilidade dos dados obtidos deve ser maior que a definida por uma tabela, em que o valor da probabilidade é definido em função do nível de significância desejado. $\mathrm{O}$ método consiste na elaboração de uma tabela que contenha:

i - número do dado.

$\mathrm{Xi}$ - valor do dado.

Xn-i - valor que se obtém por n, que é o número total de dados.

ai - valores de coeficientes obtidos por tabela do método, em função do número total de dados.

Em seguida obter o valor de SW, dado por:

$$
\begin{aligned}
& S W=\sum a i \times\left(S_{n-i}-x_{i}\right) \\
& S Q T=(\text { eq. } 4.6) \\
& S S_{x}^{2} \\
& W=S W^{2} / S Q T
\end{aligned}
$$

onde o valor $\mathrm{W}$ obtido é comparado com o valor de tabela para um intervalo de confiança estipulado.

Para dados contínuos, ou seja, aqueles que não apresentam valores precisos e estão sujeitos a erros de medidas dos parâmetros, a construção dos histogramas deve obedecer à formação de um número característico de classes de valores, definindo intervalos de mesma amplitude ou largura no eixo x. Este valor deve se situar entre 5 e 15 e pode ser calculado segundo as seguintes regras, conforme LAPPONI (1997) e WAENY (1992) :

a) $n^{\circ}$ de classes é igual à raiz quadrada da quantidade de valores obtida;

b) $n^{\circ}$ de classes é igual à expressão: $1+3,322 \log n$, em que $n$ é a quantidade de valores obtidos;

c) menor valor inteiro que satisfaz a relação: $2^{k} \leq n$. 
Em seguida, obtém-se o intervalo de variação, que é definido pela diferença do maior valor pelo menor valor do conjunto de dados. A amplitude da classe é dada pela divisão entre o intervalo de variação e o número de classes.

O gráfico de boxes é uma forma de representação gráfica de médias, desvios e valores. O gráfico mostra centros de dados, dispersão, presença de simetria, identificação de valores não usuais. Emprega conceitos de mediana. Os dados analisados devem ser divididos em duas partes e obtêm-se as medianas desses conjuntos de dados, que definem a dispersão da quarta parte ${ }^{8}$. A área definida pelo retângulo indica esta dispersão, as linhas indicam a região onde os valores continuam a se propagar dentro do limite de 1,5 vez o valor da dispersão, definido pela diferença entre as medianas dos conjuntos de dados da meia parte. Após estas linhas, os pontos vazios indicam valores espúrios moderados ${ }^{9}$ e os pontos preenchidos indicam os valores espúrios extremos ${ }^{10}$.

A retirada de valores espúrios foi baseada no critério de DIXON, citado por WAENY (1992). Este método se baseia na conformidade com a função de distribuição normal. Deve-se estabelecer um limite para os descartes de valores, como $10 \%$ por exemplo. O método consiste em colocar os valores em ordem crescente, para obter um coeficiente de DIXON, calculado a partir da seguinte fórmula:

$$
r d=\frac{\left(x_{3}-x_{1}\right)}{\left(x_{n-2}-x_{1}\right)} e \frac{\left(x_{n}-x_{n-2}\right)}{x_{n}-x_{3}}
$$

A partir dos coeficientes rd obtidos, considerar o maior deles. Compara-se agora este coeficiente com um obtido por uma tabela na qual se informa o número de amostras e o intervalo de confiança pretendido, sendo de $95 \%$ para este caso.

${ }^{8}$ Do inglês fourth spread.

${ }^{9}$ Do inglês mild outliers.

${ }^{10}$ Do inglês extreme outliers. 


\section{RESULTADOS E DISCUSSÕES}

\subsection{Estudo da composição por análise de imagem}

Os resultados do estudo da composição de agregados graúdos de RCD reciclados, por análise de imagem, foram analisados para os seguintes itens: (a) teste de fundo padrão para as imagens dos agregados, (b) precisão da determinação das dimensões por análise de imagem, (c) estudo da capacidade de separação das fases pelo programa de análise de imagem, (d) correlação entre área e volume das fases da composição com ou sem orientação dos agregados no plano, (e) correlação entre área e massa das fases da composição e (f) procedimento para a separação das fases pelo programa.

\subsubsection{Teste de fundo padrão para os agregados}

Uma forma de se identificar fases na imagem pelo programa é por segmentação de cores ${ }^{11}$. Neste processo, cores de fundo semelhantes às cores dos agregados podem se confundir, tornando difícil a seleção dos agregados em relação ao fundo.

Em relação às cores de fundo testadas (preto, verde e laranja), a lona preta foi a que permitiu maior contraste para a seleção dos grãos por segmentação de cores e a lona laranja não apresentou bons resultados, como pode ser visto na Figura 5.1. Ela mostra a tentativa de segmentação da imagem por cor, conforme observado a máscara ${ }^{12}$ gerada (b) em relação à imagem original (a).

${ }^{11}$ No programa (Menu measurement, Count/Size, Select Ranges).

${ }^{12}$ A máscara é o resultado da segmentação em preto e branco. No programa (Menu measurement, Count/Size, Select Ranges, Make a mask). 


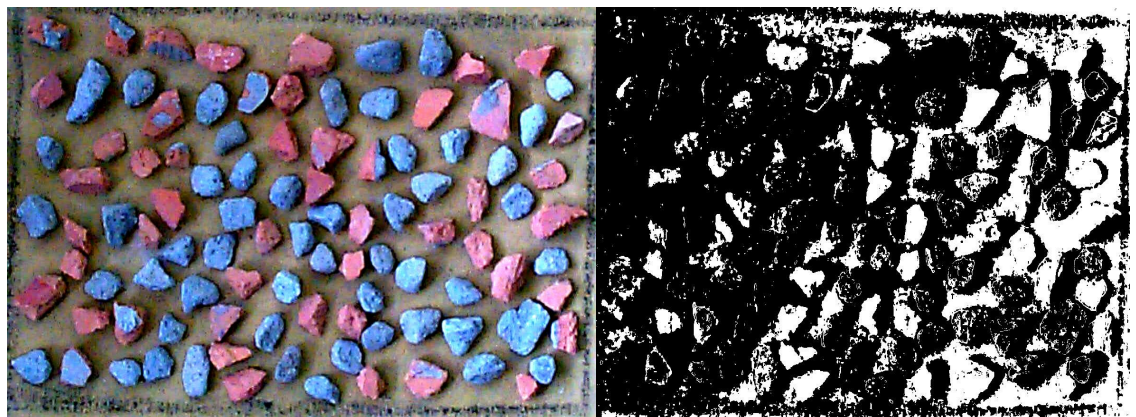

(a)

(b)

Figura 5.1 - Tentativa de segmentação de cores por RGB dos agregados com um fundo laranja, (a) imagem original e (b) máscara.

Para este caso, a cor da fase cerâmica foi segmentada junto com o fundo laranja. Por esta razão, recomenda-se fundos de cor bem diferente das cores das fases presentes na composição.

O uso de recursos como fonte de iluminação direta ou "flash" pode prejudicar na segmentação por cores com fundos reflexivos conforme a Figura 5.2.

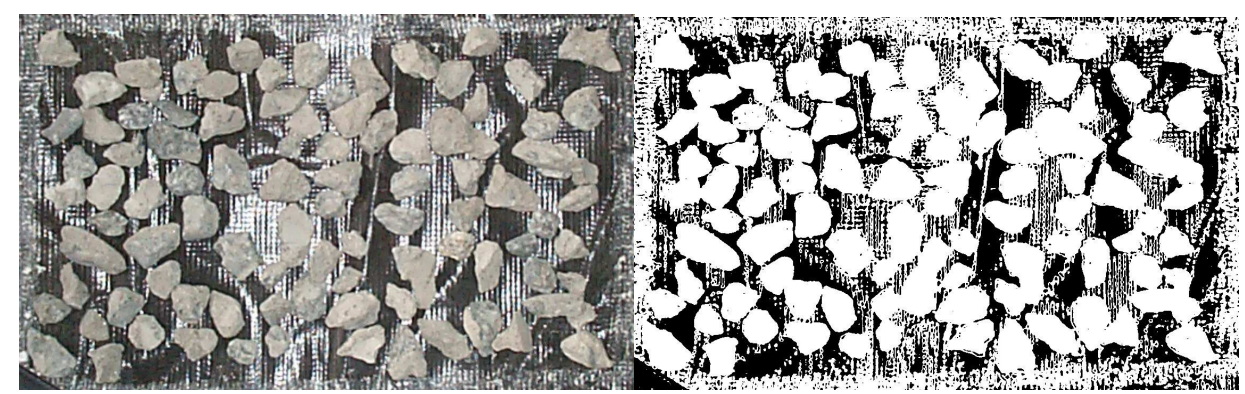

(a)

(b)

Figura 5.2 - Tentativa de segmentação de cores por RGB dos agregados de concreto com um fundo preto reflexivo, (a) imagem original e (b) máscara.

Ela mostra a semelhança de cor do fundo preto reflexivo com os agregados reciclados de concreto, quando utilizado flash e luz artificial, que no processo de segmentação confunde grãos com o fundo. Destaca-se que problemas de pouca luminosidade podem ser resolvidos com ajuste de brilho e contraste do programa.

Qualitativamente, selecionou-se para estudos posteriores fundos verde não reflexivo e preto reflexivo, sendo preferível o preto graças ao contraste maior com os agregados. O uso de recursos como "flash" e luz artificial não melhorou a segmentação, dificultando quando utilizado fundo reflexivo.

Não se forneceu, nesta etapa, os intervalos de valores RGB em que havia cruzamento com os fundos escolhidos, uma vez que estes valores são muito variáveis, 
dependendo de cada amostra caracterizada. A cor deve ser quantificada por melhores e mais precisos equipamentos. ${ }^{13}$

\subsubsection{Precisão da determinação das dimensões por análise de imagem}

Para determinar as dimensões dos grãos pelo programa é necessário informar um sistema de calibração ${ }^{14}$, criando-se uma escala entre os "pixels" e milímetros. A Tabela 5.1 apresenta os resultados comparativos entre as dimensões dos grãos medidas por paquímetro e as dimensões avaliadas pelo programa, grãos estes identificados no item 4.2.1.2, no quarto capítulo. Calculou-se um erro expresso pela diferença da dimensão avaliada e da determinada, dividida pela dimensão determinada, expresso em porcentagem. Os erros encontrados estão abaixo de 3\%, em módulo, para as dimensões de agregado em torno de $12,7 \mathrm{~mm}$, valor considerado aceitável. Admite-se que o sistema de calibração do programa é de fácil entendimento e que confere boa precisão na determinação de características de forma (comprimento, largura e espessura dos grãos).

Tabela 5.1 - Resultados comparativos entre as dimensões dos agregados.

\begin{tabular}{|c|c|c|c|c|}
\hline Agregados & Imagens & $\begin{array}{c}\text { Distância pelo } \\
\text { paquímetro }(\mathbf{m m})\end{array}$ & $\begin{array}{c}\text { Distância pela } \\
\text { análise de imagem } \\
(\mathbf{m m})\end{array}$ & $\begin{array}{c}\text { Erro } \\
(\%)\end{array}$ \\
\hline $\begin{array}{l}\text { Superior } \\
\text { esquerdo }\end{array}$ & & 24,4 & 24,12 & $-1,15$ \\
\hline $\begin{array}{l}\text { Superior } \\
\text { direito }\end{array}$ & & 34,6 & 35,29 & $+1,99$ \\
\hline $\begin{array}{l}\text { Inferior } \\
\text { esquerdo }\end{array}$ & & 32,0 & 32,62 & $+1,93$ \\
\hline Inferior direito & & 30,0 & 29,19 & $-2,70$ \\
\hline
\end{tabular}

${ }^{13}$ Informações do Prof. Dr. Henrique Kahn, professor da Engenharia de Minas da Escola Politécnica da Universidade de São Paulo.

${ }^{14}$ No programa (Menu measurement, Calibration) 


\subsubsection{Estudo da capacidade de separação das fases pelo programa de análise de imagem}

O objetivo era avaliar se o programa era capaz de separar automaticamente as fases da composição, segundo intervalos de valores quantitativos dos parâmetros, expostos no capítulo 4 item 4.2.1.3, para as fases.

Para isto, a demarcação dos contornos dos grãos foi feita de maneira nãoautomática (manual). Assim, separam-se os grãos pertencentes a uma fase e gerou-se uma máscara. Em seguida, gerou-se outra imagem, contendo somente grãos desta fase, através do comando RESTRICT DILATION ${ }^{15}$, com a máscara da fase e a imagem original. Fornecendo os dados de calibração, pôde-se efetuar a medida dos parâmetros do programa automaticamente para esta fase. Este procedimento foi repetido para todas as fases presentes na imagem.

A Tabela 5.2 mostra imagens das composições e fases estudadas, os parâmetros avaliados e fornecidos pelo programa, após a análise de imagens.

Tabela 5.2 - Resumo dos parâmetros, fases e composições estudadas no programa.

\begin{tabular}{|c|c|c|c|c|c|}
\hline Composição & Imagem & $\begin{array}{l}\text { Fase } \\
\text { Concreto }\end{array}$ & $\begin{array}{l}\text { Fase } \\
\text { Argamassa }\end{array}$ & $\begin{array}{l}\text { Fase } \\
\text { Cerâmica }\end{array}$ & $\begin{array}{l}\text { Parâmetros } \\
\text { Avaliados }\end{array}$ \\
\hline $\begin{array}{l}\text { Argamassa/ } \\
\text { Cerâmica } \\
12,7 \mathrm{~mm}\end{array}$ & 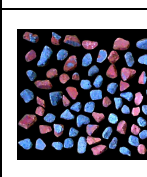 & & & & $\begin{array}{l}\text { Área } \\
\text { Aspecto } \\
\text { Densidade média } \\
\text { Eixo maior } \\
\text { Fixo menor }\end{array}$ \\
\hline $\begin{array}{l}\text { Argamassa/ } \\
\text { Cerâmica \# } \\
9,5 \mathrm{~mm}\end{array}$ & 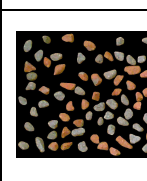 & & & & $\begin{array}{l}\text { Exxo menor } \\
\text { Diâmetro máximo } \\
\text { Diâmetro mínimo } \\
\text { Diâmetro médio } \\
\text { Raio máximo }\end{array}$ \\
\hline $\begin{array}{l}\text { Argamassa/ } \\
\text { Concreto } \\
12,7 \mathrm{~mm}\end{array}$ & $\begin{array}{l}088 \\
088 \\
008 \\
008\end{array}$ & & & & $\begin{array}{l}\text { Perímetro } \\
\text { Esfericidade } \\
\text { Densidade vermelho } \\
\text { Densidade verde }\end{array}$ \\
\hline $\begin{array}{l}\text { Argamassa/ } \\
\text { Concreto } \\
9,5 \mathrm{~mm}\end{array}$ & 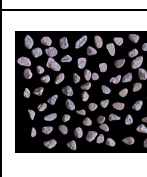 & & & & $\begin{array}{l}\text { Densidade azul } \\
\text { IOD } \\
\text { Dimensão fractal } \\
\text { Feret máximo } \\
\text { Feret mínimo }\end{array}$ \\
\hline $\begin{array}{l}\text { Argamassa } \\
\text { Concreto \# } 6,25 \\
\mathrm{~mm}\end{array}$ & 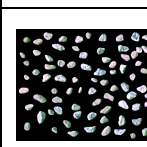 & & & & Margination \\
\hline
\end{tabular}

${ }^{15}$ No programa (Menu Process, Restrict Diltation). 
Assim, obtiveram-se planilhas do programa Excel com os valores dos parâmetros do programa, para cada fase presente na composição. A seguir, será mostrado o modelo da planilha de saída de dados, com as informações de uma fase de uma composição estudada, conforme a Tabela 5.3.

\section{Tabela 5.3 - Parâmetros da fase cerâmica da composição argamassa e cerâmica retidos em peneira normal de abertura de malha $12,7 \mathrm{~mm}$.}

\begin{tabular}{|c|c|c|c|c|c|c|c|}
\hline \multicolumn{8}{|c|}{ Fase cerâmica - composição Argamassa/ Cerâmica \# 12,5 mm } \\
\hline Dados & $\begin{array}{c}\text { Diâmetro } \\
\text { máximo } \\
(\mathrm{cm})\end{array}$ & $\begin{array}{c}\text { Diâmetro } \\
\text { mínimo } \\
(\mathrm{cm})\end{array}$ & $\begin{array}{c}\text { Raio } \\
\text { máximo } \\
(\mathrm{cm})\end{array}$ & $\begin{array}{c}\text { Raio } \\
\text { mínimo } \\
\text { (cm) }\end{array}$ & $\begin{array}{l}\text { Perímetro } \\
(\mathrm{cm})\end{array}$ & Esfericidade & $\begin{array}{c}\text { Densidade } \\
\text { vermelho }\end{array}$ \\
\hline Mínimo & \begin{tabular}{|l|}
1,274 \\
\end{tabular} & 0,914 & 0,722 & 0,399 & 3,690 & 1,010 & 67,478 \\
\hline Máximo & 3,336 & 2,129 & 1,772 & 0,991 & 8,845 & 1,356 & 115,605 \\
\hline Variação & 2,062 & 1,215 & 1,050 & 0,593 & 5,155 & 0,347 & 48,127 \\
\hline Média & 2,189 & 1,409 & 1,186 & 0,655 & 6,010 & 1,139 & 90,030 \\
\hline Desvio padrão & 0,449 & 0,266 & 0,237 & 0,123 & 1,072 & 0,081 & 11,309 \\
\hline Soma & 105,088 & 67,618 & 56,949 & 31,437 & 288,468 & 54,659 & 4321,427 \\
\hline Número grãos & 48,000 & 48,000 & 48,000 & 48,000 & 48,000 & 48,000 & 48,000 \\
\hline \multicolumn{8}{|c|}{ Fase cerâmica - composição Argamassa/ Cerâmica \# 12,5 mm } \\
\hline Dados & $\begin{array}{c}\text { Densidade } \\
\text { verde }\end{array}$ & $\begin{array}{c}\text { Densidade } \\
\text { azul }\end{array}$ & IOD & $\begin{array}{c}\text { Dimensão } \\
\text { Fractal }\end{array}$ & $\begin{array}{c}\text { Feret } \\
\text { máximo } \\
(\mathrm{cm})\end{array}$ & $\begin{array}{c}\text { Feret } \\
\text { mínimo } \\
(\mathrm{cm})\end{array}$ & Margination \\
\hline Mínimo & 59,418 & 62,119 & 81,221 & 1,040 & 1,333 & 1,179 & 0,306 \\
\hline Máximo & 90,471 & 104,527 & 504,170 & 1,097 & 3,318 & 2,811 & 0,348 \\
\hline Variação & 31,053 & 42,408 & 422,949 & 0,057 & 1,986 & 1,632 & 0,041 \\
\hline Média & 71,786 & 80,641 & 208,359 & 1,055 & 2,234 & 1,908 & 0,326 \\
\hline Desvio padrão & \begin{tabular}{|l|}
8,559 \\
\end{tabular} & 12,151 & 74,653 & 0,012 & 0,445 & 0,338 & 0,010 \\
\hline Soma & 3445,710 & 3870,766 & 10001 & 50,661 & 107,223 & 91,568 & 15,670 \\
\hline Número grãos & 48,000 & 48,000 & 48,000 & 48,000 & 48,000 & 48,000 & 48,000 \\
\hline
\end{tabular}

Convém ressaltar que os valores de densidades verde, azul e vermelho devem apresentar valores inteiros nos itens definidos como máximo e mínimo. Já valores como média não precisam ser inteiros. Os valores numéricos destas densidades, que não o valor do número inteiro, não possuem significado físico. Na verdade, a separação por cores utilizando esses valores não deve ser empregada no método de análise de imagem, conforme mencionado anteriormente.

Seria necessário regulagem das intensidades de 0 a 255 da combinação dos "bytes" em função da superfície onde se conseguem as imagens, além de condições de controle sobre a iluminação. A ausência dessa regulagem dos padrões de cores pode ser responsável pelo fato de não se apresentarem como valores inteiros. 
Em seguida, criou-se uma planilha com informações sobre média, desvio padrão, número de grãos, valores máximos e mínimos para os parâmetros selecionados por fases. Com as planilhas, compararam-se os intervalos de valores dos parâmetros e verificou-se sobreposição de valores entre eles para as fases da composição. Alguns dados podem ser observados na Tabela 5.4. 
Tabela 5.4 - Valores de alguns parâmetros selecionados segundo fases.

\begin{tabular}{|c|c|c|c|c|c|c|c|c|}
\hline \multirow[b]{2}{*}{ Aspecto } & \multicolumn{3}{|c|}{$\begin{array}{l}\text { Grãos retidos em peneira normal } \\
\text { de abertura de malha } 12,7 \mathrm{~mm} \\
\text { Concreto Argamassa Cerâmica }\end{array}$} & \multicolumn{3}{|c|}{$\begin{array}{l}\text { Grãos retidos em peneira normal } \\
\text { de abertura de malha } 9,5 \mathrm{~mm} \\
\text { Concreto Argamassa Cerâmica }\end{array}$} & \multicolumn{2}{|c|}{$\begin{array}{l}\text { Grãos retidos em peneira normal } \\
\text { de abertura de malha } 6,25 \mathrm{~mm} \\
\text { Concreto Argamassa }\end{array}$} \\
\hline & & & & & & & & \\
\hline média & 1,403 & 1,391 & 1,469 & 1,496 & 1,461 & 1,52 & 1,489 & 1,454 \\
\hline desvio padrão & 0,261 & 0,231 & 0,28 & 0,259 & 0,235 & 0,341 & 0,294 & 0,264 \\
\hline máximo & 2,311 & 2,116 & 2,153 & 2,297 & 2,166 & 2,909 & 2,149 & 2,067 \\
\hline mínimo & 1,068 & 1,022 & 1,075 & 1,146 & 1,043 & 1,038 & 0,418 & 1,048 \\
\hline numero grãos & 28 & 54 & 48 & 62 & 56 & 43 & 76 & 43 \\
\hline \multicolumn{9}{|c|}{ Eixo maior $(\mathrm{cm})$} \\
\hline média & 2,524 & 2,087 & 2,189 & 1,823 & 1,814 & 1,868 & 1,558 & 1,379 \\
\hline desvio padrão & 0,529 & 0,392 & 0,469 & 0,263 & 0,248 & 0,345 & 0,283 & 0,308 \\
\hline máximo & 3,429 & 3,73 & 3,456 & 2,565 & 2,648 & 3,142 & 2,498 & 2,239 \\
\hline mínimo & 1,479 & 1,353 & 1,282 & 1,363 & 1,359 & 1,388 & 0,929 & 0,917 \\
\hline numero grãos & 28 & 54 & 48 & 62 & 56 & 43 & 76 & 43 \\
\hline \multicolumn{9}{|c|}{ Eixo menor $(\mathrm{cm})$} \\
\hline média & 1,804 & 1,511 & 1,505 & 1,235 & 1,252 & 1,248 & 1,06 & 0,95 \\
\hline desvio padrão & 0,267 & 0,22 & 0,266 & 0,166 & 0,132 & 0,16 & 0,152 & 0,125 \\
\hline máximo & 2,318 & 2,327 & 2,283 & 1,629 & 1,7 & 1,624 & 1,316 & 1,213 \\
\hline mínimo & 1,295 & 1,143 & 0,959 & 0,802 & 0,939 & 0,998 & 0,501 & 0,644 \\
\hline numero grãos & 28 & 54 & 48 & 62 & 56 & 43 & 76 & 43 \\
\hline \multicolumn{9}{|c|}{$\begin{array}{l}\begin{array}{l}\text { Diâmetro máximo } \\
(\mathrm{cm})\end{array} \\
\end{array}$} \\
\hline média & 2,53 & 2,085 & 2,189 & 1,804 & 1,798 & 1,867 & 1,551 & 1,356 \\
\hline desvio padrão & 0,517 & 0,359 & 0,448 & 0,26 & 0,227 & 0,327 & 0,279 & 0,291 \\
\hline máximo & 3,526 & 3,463 & 3,336 & 2,498 & 2,581 & 2,999 & 2,423 & 2,168 \\
\hline mínimo & 1,568 & 1,381 & 1,274 & 1,36 & 1,349 & 1,411 & 0,922 & 0,935 \\
\hline numero grãos & 28 & 54 & 48 & 62 & 56 & 43 & 76 & 43 \\
\hline \multicolumn{9}{|c|}{$\begin{array}{l}\text { Diâmetro mínimo } \\
\text { (cm) }\end{array}$} \\
\hline média & 1,703 & 1,428 & 1,408 & 1,172 & 1,188 & 1,17 & 0,998 & 0,893 \\
\hline desvio padrão & 0,254 & 0,197 & 0,266 & 0,166 & 0,119 & 0,149 & 0,146 & 0,122 \\
\hline máximo & 2,103 & 2,088 & 2,129 & 1,568 & 1,55 & 1,467 & 1,283 & 1,14 \\
\hline mínimo & 1,24 & 1,043 & 0,914 & 0,757 & 0,914 & 0,81 & 0,439 & 0,612 \\
\hline numero grãos & 28 & 54 & 48 & 62 & 56 & 43 & 76 & 43 \\
\hline \multicolumn{9}{|c|}{ Raio máximo $(\mathrm{cm})$} \\
\hline média & 1,362 & 1,114 & 1,186 & 0,952 & 0,951 & 1,006 & 0,827 & 0,711 \\
\hline desvio padrão & 0,293 & 0,196 & 0,237 & 0,133 & 0,116 & 0,172 & 0,153 & 0,15 \\
\hline máximo & 1,864 & 1,876 & 1,772 & 1,32 & 1,32 & 1,624 & 1,288 & 1,095 \\
\hline mínimo & 0,826 & 0,756 & 0,722 & 0,734 & 0,701 & 0,749 & 0,473 & 0,492 \\
\hline numero grãos & 28 & 54 & 48 & 62 & 56 & 43 & 76 & 43 \\
\hline Raio mínimo ( & & & & & & & & \\
\hline média & 0,802 & 0,666 & 0,655 & 0,545 & 0,551 & 0,538 & 0,461 & 0,416 \\
\hline desvio padrão & 0,128 & 0,092 & 0,123 & 0,09 & 0,059 & 0,074 & 0,074 & 0,063 \\
\hline máximo & 1,016 & 0,921 & 0,992 & 0,753 & 0,683 & 0,659 & 0,63 & 0,563 \\
\hline mínimo & 0,567 & 0,484 & 0,399 & 0,329 & 0,424 & 0,331 & 0,199 & 0,279 \\
\hline numero grãos & 28 & 54 & 48 & 62 & 56 & 43 & 76 & 43 \\
\hline Esfericidade ( & & & & & & & & \\
\hline média & 1,125 & 1,11 & 1,139 & 1,1 & 1,09 & 1,14 & 1,11 & 1,068 \\
\hline desvio padrão & 0,098 & 0,063 & 0,081 & 0,083 & 0,053 & 0,092 & 0,093 & 0,064 \\
\hline máximo & 1,417 & 1,303 & 1,356 & 1,406 & 1,253 & 1,529 & 1,46 & 1,253 \\
\hline mínimo & 1,001 & 1,001 & 1,01 & 1 & 1,019 & 1,034 & 1 & 1 \\
\hline numero grãos & 28 & 54 & 48 & 62 & 56 & 43 & 76 & 43 \\
\hline Dens. Vermelh & & & & & & & & \\
\hline média & 156,671 & 68,812 & 90,03 & 133,398 & 145,4 & 174,891 & 166,326 & 164,916 \\
\hline desvio padrão & 11,869 & 6,843 & 11,309 & 15,023 & 12,355 & 14,182 & 24,033 & 26,053 \\
\hline máximo & 187,401 & 89,421 & 115,605 & 168,071 & 176,054 & 206,85 & 220,741 & 217,913 \\
\hline mínimo & 135,892 & 54,033 & 67,478 & 96,922 & 108,31 & 147,842 & 120,108 & 108,887 \\
\hline numero grãos & 28 & 54 & 48 & 62 & 56 & 43 & 76 & 43 \\
\hline Dens. Verde & & & & & & & & \\
\hline média & 145,042 & 82,156 & 71,786 & 122,856 & 136,102 & 116,91 & 177,912 & 170,342 \\
\hline desvio padrão & 10,843 & 8,907 & 8,559 & 14,041 & 12,572 & 10,335 & 12,81 & 12,853 \\
\hline máximo & 175,758 & 105,993 & 90,471 & 154,729 & 167,239 & 140,493 & 212,348 & 195,405 \\
\hline mínimo & 126,265 & 62,973 & 59,418 & 88,905 & 98,973 & 93,779 & 148,27 & 140,519 \\
\hline numero grãos & 28 & 54 & 48 & 62 & 56 & 43 & 76 & 43 \\
\hline Dens. Azul & & & & & & & & \\
\hline média & 164,677 & 106,511 & 80,641 & 138,353 & 116,1 & 72,596 & 186,444 & 167,567 \\
\hline desvio padrão & 12,196 & 14,722 & 12,151 & 17,603 & 19,342 & 17,062 & 21,503 & 23,274 \\
\hline máximo & 199,613 & 139,844 & 104,527 & 175,624 & 155,174 & 106,508 & 238,129 & 211,529 \\
\hline mínimo & 143,872 & 75,775 & 62,119 & 96,067 & 51,511 & 40,037 & 138,329 & 106,763 \\
\hline numero grãos & 28 & 54 & 48 & 62 & 56 & 43 & 76 & 43 \\
\hline Feret máximo & & & & & & & & \\
\hline média & 2,58 & 2,122 & 2,234 & 1,829 & 1,824 & 1,896 & 1,576 & 1,375 \\
\hline desvio padrão & 0,527 & 0,369 & 0,445 & 0,259 & 0,227 & 0,322 & 0,28 & 0,292 \\
\hline máximo & 3,534 & 3,553 & 3,318 & 2,565 & 2,587 & 2,985 & 2,432 & 2,168 \\
\hline
\end{tabular}


Para avaliar a sobreposição de valores dos dados da Tabela 5.4, foram montados gráficos considerando os dados fornecidos como distribuição normal.

Nas figuras abaixo incluem-se os valores de limite superior e inferior (representados pelas linhas) e os dois valores obtidos pela média, somados e subtraídos do desvio padrão, que se referem à inserção de $63 \%$ dos valores dentro desse intervalo (representados pelo retângulo).

Todos os parâmetros, exceto um, se revelaram incapazes de selecionar as fases nas diferentes faixas granulométricas porque apresentavam superposições significativas, mesmo se considerando intervalo de valores para grãos de dimensões iguais. O único parâmetro que permitiu a seleção das fases, para a maior parte dos valores, foram as densidades vermelho, verde e azul.

Na Figura 5.3 e na Figura 5.4 percebe-se que à medida que os grãos se tornam menores, a seleção pela densidade do padrão RGB torna-se mais difícil para as fases concreto e argamassa, aumentando a sobreposição de valores. A fase cerâmica teve a maior parte dos valores em intervalos separados, acima de 50\%, para grãos com dimensão em torno de $9,5 \mathrm{~mm}$ e $12,7 \mathrm{~mm}$ para a densidade azul e vermelha.

A densidade verde é tão importante quanto a azul ou a vermelha. A densidade verde não foi utilizada para este caso pois houve uma sobreposição de valores maior.

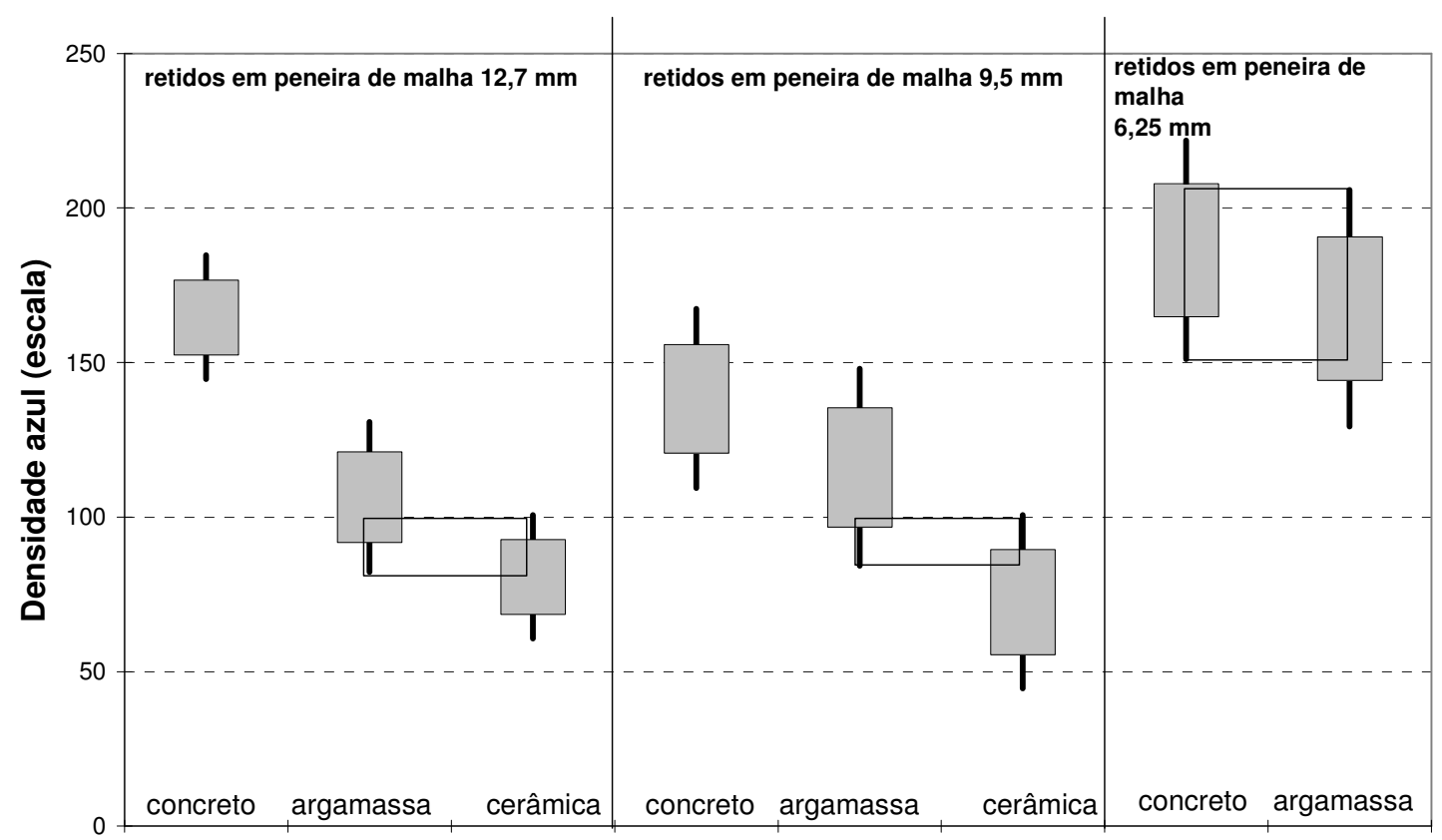

Fases da composições

Figura 5.3 - Densidade da cor azul do padrão RGB e as faixas de valores em função das fases. 


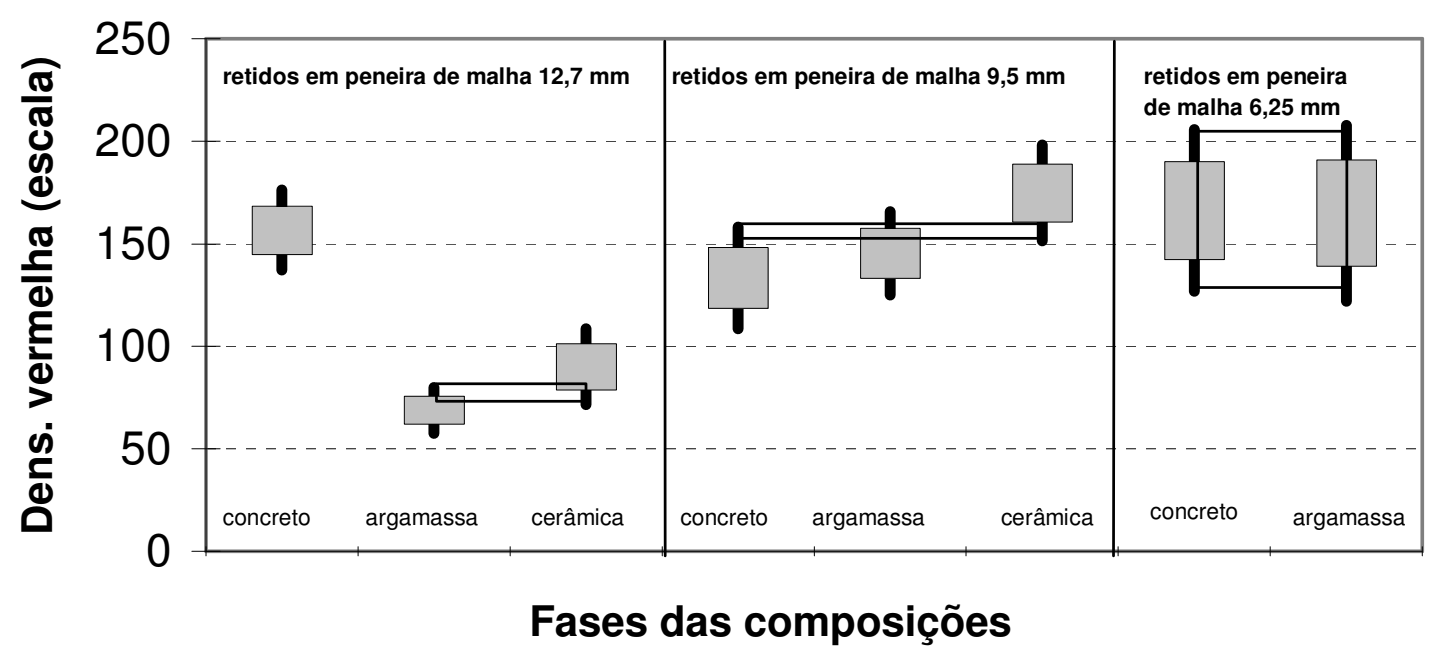

Figura 5.4 - Densidade da cor vermelha do padrão RGB e as faixas de valores em função das fases.

Por estes dados conclui-se que as fases concreto/argamassa e cerâmica são distintas entre si, pelo padrão RGB, mesmo em processos de obtenção de imagem em que as condições de iluminação não são controladas. Porém, conforme as discussões anteriores, esses valores quantitativos não devem ser fixados, pois os mesmos irão variar.

A diferenciação entre concreto e argamassa pelo padrão RGB talvez possa ser mais eficientemente realizada com condições de iluminação controlada. Esse teste não foi abordado no escopo deste trabalho.

Conclui-se que o padrão RGB pode separar a fase cerâmica por segmentação de cores uma vez que a fase apresenta uma pequena faixa de sobreposição de valores com as fases concreto/argamassa. Não foi possível a separação automática das fases concreto e argamassa, somente pela geração manual de linhas externas no programa quando as fases são reconhecidas visualmente na imagem.

\subsubsection{Correlações entre \%área e \%volume}

O objetivo deste estudo é verificar a influência da orientação dos grãos no seu plano de maiores dimensões na correlação entre área e volume dos grãos de uma fase. 


\subsubsection{Com orientação dos grãos}

Fez-se a verificação da correlação entre área e volume para as fases cerâmica e concreto/argamassa. Foram separados todos os grãos de cerâmica por segmentação de cores no padrão RGB em relação ao fundo e criou-se uma máscara. Em seguida, separaram-se todos os grãos por esta segmentação e criou-se outra máscara. Aplicou-se o filtro $O P E N^{16}$ nas duas máscaras para unir os "pixels" segmentados em grãos e retirar pequenas imperfeições. Pelo comando RESTRICT DILATION separam-se os grãos de cada fase em imagens diferentes.

Após calibração do programa, realizaram-se medidas de áreas dos grãos de cerâmica por camada e as áreas totais dos grãos nas camadas.

A Tabela 5.5 mostra as áreas estimadas dos grãos para as duas fases analisadas.

${ }^{16}$ No programa (Menu Process, Filters) 
Tabela 5.5- Áreas estimadas dos grãos com orientação dos grãos.

\begin{tabular}{|c|c|c|c|c|}
\hline $\begin{array}{c}\text { Camada em } \\
\text { ordem de } \\
\text { numeração }\end{array}$ & Área total $\left(\mathrm{cm}^{2}\right)$ & $\begin{array}{l}\text { Cerâmica da } \\
\text { camada }\end{array}$ & Área cerâmica $\left(\mathrm{cm}^{2}\right)$ & $\begin{array}{c}\text { Área conc/arg } \\
\qquad\left(\mathrm{cm}^{2}\right)\end{array}$ \\
\hline 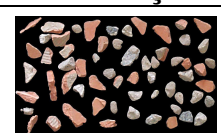 & 226,2 & & 119,95 & 106,25 \\
\hline & 229,7 & & 119,95 & 109,75 \\
\hline 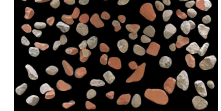 & 230,1 & & 110,99 & 119,11 \\
\hline & 231,5 & & 101,19 & 130,31 \\
\hline & 244,3 & & 114,67 & 129,63 \\
\hline & 238,3 & & 86,24 & 152,06 \\
\hline & 245,6 & & 88,33 & 157,27 \\
\hline & 266,9 & & 75,32 & 191,58 \\
\hline & 279,4 & & 104,75 & 174,65 \\
\hline 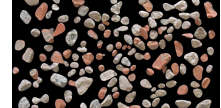 & 268,6 & & 92,06 & 176,54 \\
\hline - & 255,5 & & 107,98 & 147,52 \\
\hline & 257,1 & & 107,43 & 149,67 \\
\hline & 308,7 & & 108,94 & 199,76 \\
\hline 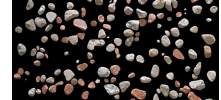 & 187,5 & & 57,33 & 130,17 \\
\hline
\end{tabular}


Em seguida, esses valores de área estimados foram convertidos em porcentagem. A área total dos grãos, neste caso, equivale a $100 \%$. Estes percentuais obtidos devem ser considerados iguais aos percentuais de volume.

A Tabela 4.4, do quarto capítulo, mostra o cálculo de volume das fases da composição real. Por esta tabela, a fase cerâmica tem um volume real de $36 \%$ e a fase concreto/argamassa tem um de $64 \%$.

A Tabela 5.7 compara a composição real (obtida pelo volume) e a estimada (obtida pela área) para as fases. O erro foi obtido pela diferença entre o teor da composição estimada e o da composição real, dividida pelo teor da composição real, expresso em porcentagem.

\section{Tabela 5.7 - Comparação entre composição real e estimada para as fases da composição, com orientação dos grãos no plano.}

\begin{tabular}{|c|c|c|c|c|c|c|}
\hline \multirow[t]{2}{*}{$\begin{array}{l}\text { Numero } \\
\text { Camada }\end{array}$} & \multicolumn{3}{|c|}{$\begin{array}{c}\text { Composição fase cerâmica } \\
(\%)\end{array}$} & \multicolumn{3}{|c|}{ Composição fase concreto/argmassa (\%) } \\
\hline & Real & Estimada & Erro & Real & Estimada & Erro \\
\hline 1 & 36,00 & 53,03 & $+32,11$ & 64,00 & 46,97 & $-26,61$ \\
\hline 2 & 36,00 & 52,22 & $+45,05$ & 64,00 & 47,78 & $-25,34$ \\
\hline 3 & 36,00 & 48,23 & $+33,97$ & 64,00 & 51,77 & $-19,11$ \\
\hline 4 & 36,00 & 43,70 & $+21,39$ & 64,00 & 56,30 & $-12,03$ \\
\hline 5 & 36,00 & 46,94 & $+30,39$ & 64,00 & 53,06 & $-17,09$ \\
\hline 6 & 36,00 & 36,18 & $+0,50$ & 64,00 & 63,82 & $-0,28$ \\
\hline 7 & 36,00 & 35,97 & $+0,08$ & 64,00 & 64,03 & $+0,05$ \\
\hline 8 & 36,00 & 28,22 & $-21,61$ & 64,00 & 71,78 & $+12,16$ \\
\hline 9 & 36,00 & 37,59 & $+4,42$ & 64,00 & 62,41 & $-2,48$ \\
\hline 10 & 36,00 & 34,27 & $-4,81$ & 64,00 & 65,73 & $+2,70$ \\
\hline 11 & 36,00 & 42,26 & $+17,39$ & 64,00 & 57,74 & $-9,78$ \\
\hline 12 & 36,00 & 41,78 & $+16,05$ & 64,00 & 58,22 & $-9,03$ \\
\hline 13 & 36,00 & 35,29 & $-1,97$ & 64,00 & 64,71 & $+1,11$ \\
\hline 14 & 36,00 & 30,62 & $-14,94$ & 64,00 & 69,38 & $+8,41$ \\
\hline \multicolumn{2}{|c|}{ Média } & 40,45 & $+11,28$ & Média & 59,55 & $-6,95$ \\
\hline \multicolumn{2}{|c|}{ Desvio } & 7,71 & & Desvio & 7,71 & \\
\hline \multicolumn{2}{|c|}{$\mathrm{CV}(\%)$} & 19,07 & & $\mathrm{CV}(\%)$ & 12,95 & \\
\hline
\end{tabular}

O erro obtido foi considerado excessivo e este erro pode ser atribuído a orientação dos grãos no plano preferencial de uma ou mais fases presentes. Nada se pode afirmar a respeito da orientação da cerâmica. Para se reduzir o erro, podem-se adotar duas soluções, a) garantir a não-orientação (aleatoriedade) dos grãos nas camadas ou b) corrigir o erro de orientação dos grãos nas camadas pelo valor médio.

\subsubsection{Sem orientação dos grãos}

Conforme detalhado no quarto capítulo item 4.2.1.4.2, utilizou-se uma caixa que confinava os agregados e cuja sobreposição de grãos em diversas camadas 
permitiria uma não orientação dos grãos nos planos das mesmas. Comparou-se o percentual de volume dos grãos na caixa com o percentual de área dos grãos na imagem de uma única fase. O percentual de volume dos grãos na caixa foi de 45,79\%, conforme divisão dos resultados da equação 4.1 pela equação 4.2 .

As áreas dos grãos de agregados de concreto nas camadas foram transformadas em máscara, sendo identificadas em branco em relação ao fundo preto. A Tabela 5.6 mostra as áreas dos grãos e a área total das camadas (valor constante igual a dimensão da caixa -34 x 23,3 cm).

Tabela 5.6 - Área dos grãos nas camadas.

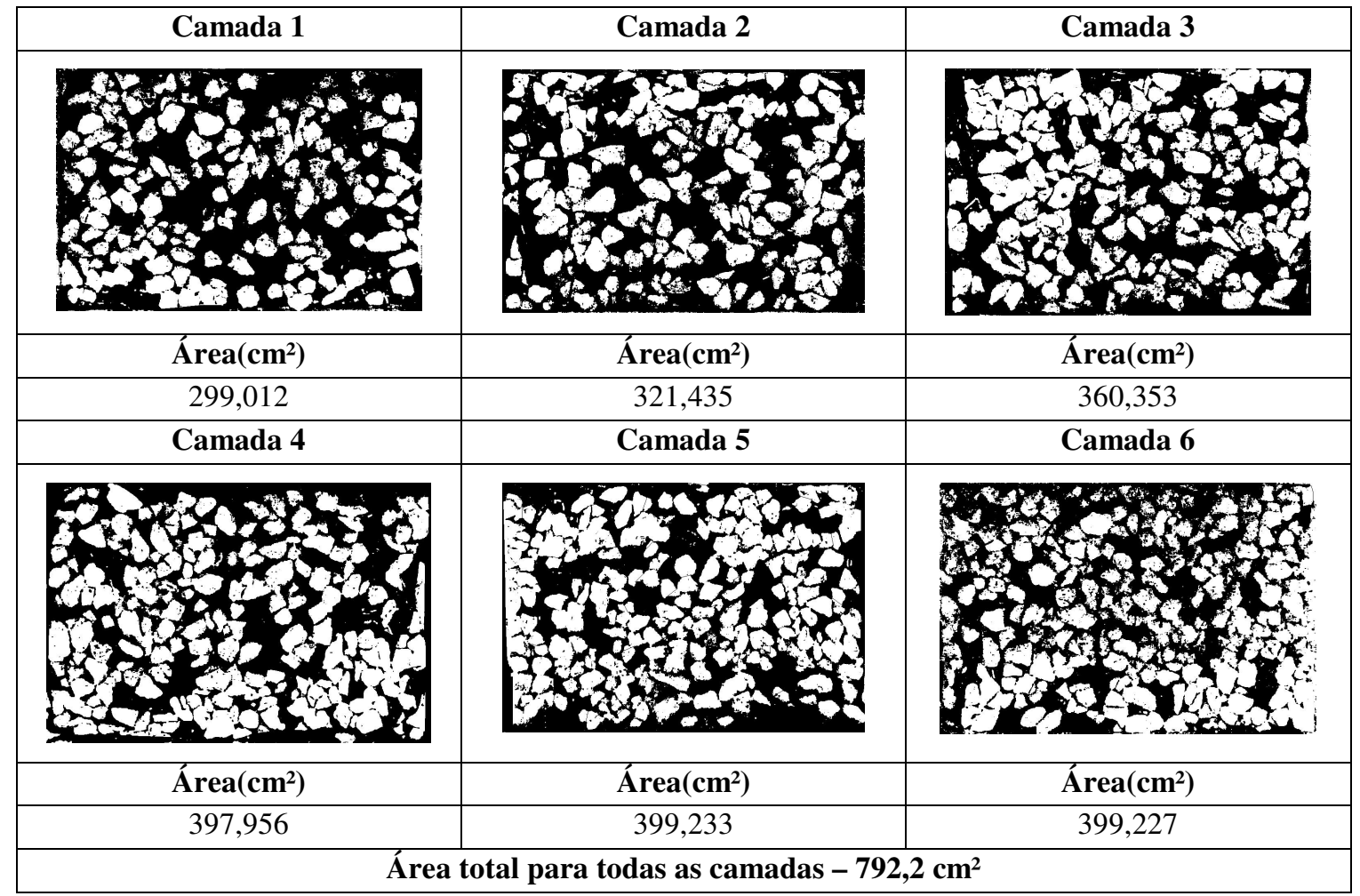

O percentual de área dos grãos é obtido pela divisão entre a área dos grãos na camada pela área total da camada, expresso em porcentagem. A Tabela 5.7 mostra a comparação entre percentual de área dos grãos das diversas camadas e percentual de volume dos grãos na caixa. O erro é calculado pela diferença entre o percentual de área dos grãos e o percentual de volume dos grãos, dividido pelo percentual de volume dos grãos, expresso em porcentagem. 
Tabela 5.7 - Comparação entre percentual de área e percentual de volume dos grãos sem orientação dos grãos no plano.

\begin{tabular}{|c|c|c|c|}
\hline $\begin{array}{c}\text { Número } \\
\text { camadas }\end{array}$ & \% volume dos grãos & $\begin{array}{c}\text { \% area dos grãos } \\
\text { nas camadas }\end{array}$ & Erro (\%) \\
\hline $\mathbf{1}$ & 45,79 & 37,74 & $-17,58$ \\
\hline $\mathbf{2}$ & 45,79 & 40,57 & $-11,40$ \\
\hline $\mathbf{3}$ & 45,79 & 45,49 & $-0,65$ \\
\hline $\mathbf{4}$ & 45,79 & 50,23 & $+9,70$ \\
\hline $\mathbf{5}$ & 45,79 & 50,39 & $+10,04$ \\
\hline $\mathbf{6}$ & 45,79 & 50,39 & $+10,04$ \\
\hline & Media & $\mathbf{4 5 , 8 0}$ & $\mathbf{+ 0 , 0 2}$ \\
\hline \multicolumn{2}{|r|}{} \\
\hline
\end{tabular}

A correlação entre percentual de área e volume é válida quando não existe orientação preferencial de grãos de concreto. O filme separador se adaptou entre os grãos, sem interferir significativamente na aleatoriedade da orientação dos grãos. Destaca-se a necessidade de constatar a correlação para as outras fases, como cerâmica e argamassa. Estas correlações serão realizadas no próximo item, em que se analisa a correlação entre área e massa dos agregados.

\subsubsection{Correlação entre \% área e \% massa}

A correlação área e massa seguiu método mencionado no item 4.4.1.2 do quarto capítulo. A separação das fases da composição por análise de imagem utilizou procedimento do item 5.1.6.

$\mathrm{Na}$ Tabela 5.8 são apresentadas as imagens do estudo e as áreas de cada fase, expressas em $\mathrm{cm}^{2}$. A média dos valores de área por fase encontra-se no item definido na tabela como média. 
Tabela 5.8 - Área das fases a partir dos resultados de análise de imagem.

\begin{tabular}{|c|c|c|c|c|}
\hline \multirow{2}{*}{ Camada 1} & \multirow{2}{*}{ Todas as fases } & Concreto & Argamassa & Cerâmica \\
\hline & & & & \\
\hline Áreas $\left(\mathrm{cm}^{2}\right)$ & 424,701 & 175,696 & 85,795 & 163,21 \\
\hline Camada 2 & लxक्यक & & & \\
\hline Áreas $\left(\mathrm{cm}^{2}\right)$ & 436,493 & 209,006 & 81,347 & 146,14 \\
\hline Camada 3 & & & & \\
\hline Áreas $\left(\mathrm{cm}^{2}\right)$ & 402,652 & 165,943 & 106,609 & 130,10 \\
\hline Camada 4 & & & & \\
\hline Áreas $\left(\mathrm{cm}^{2}\right)$ & 435,857 & 155,759 & 122,018 & 158,08 \\
\hline Camada 5 & & & & \\
\hline Áreas $\left(\mathrm{cm}^{2}\right)$ & 393,757 & 158,179 & 98,958 & 136,62 \\
\hline Camada 6 & & & & \\
\hline Áreas $\left(\mathrm{cm}^{2}\right)$ & 398,779 & 113,245 & 121,174 & 164,36 \\
\hline Camada 7 & -yzezbeg & & & \\
\hline Áreas $\left(\mathrm{cm}^{2}\right)$ & 363,420 & 140,717 & 80,003 & 142,70 \\
\hline Camada 8 & $160-9$ & & & \\
\hline Areas $\left(\mathrm{cm}^{2}\right)$ & 248,926 & 75,307 & 76,569 & 97,05 \\
\hline Média $\left(\mathrm{cm}^{2}\right)$ & & 149,23 & 96,56 & 142,28 \\
\hline
\end{tabular}


Os valores de áreas determinados para as fases em cada camada podem ser convertidos em porcentagem, considerando-se a área total dos grãos como 100\%. Esta composição percentual, obtida pela área, é igual ao volume. Esses dados são apresentados na Tabela 5.9.

Tabela 5.9 - Composição percentual das fases, obtidas pelo volume.

\begin{tabular}{|l|l|l|l|}
\hline $\begin{array}{l}\text { Numero } \\
\text { Camadas }\end{array}$ & Concreto (\%) & Argamassa (\%) & Cerâmica (\%) \\
\hline 1 & 41,37 & 20,20 & 38,43 \\
\hline 2 & 47,88 & 18,64 & 33,48 \\
\hline 3 & 41,21 & 26,48 & 32,31 \\
\hline 4 & 35,74 & 27,99 & 36,27 \\
\hline 5 & 40,17 & 25,13 & 34,70 \\
\hline 6 & 28,40 & 30,39 & 41,21 \\
\hline 7 & 38,72 & 22,01 & 39,26 \\
\hline 8 & 30,25 & 30,76 & 38,99 \\
\hline
\end{tabular}

Em seguida, converteu-se essa composição percentual, obtida pelo volume, em composição percentual estimada (pela massa), da seguinte forma:

a) multiplicaram-se os valores de massa específica de cada fase pelo percentual de volume referente à fase para as diversas camadas;

b) esses valores, em seguida, foram convertidos em porcentagem, sendo o valor da soma das três fases como $100 \%$.

Os valores de massa específica utilizados foram $2,28 \mathrm{Kg} / \mathrm{dm}^{3}$ para a fase concreto, $1,80 \mathrm{Kg} / \mathrm{dm}^{3}$ para a fase argamassa e $2,21 \mathrm{Kg} / \mathrm{dm}^{2}$ para a fase cerâmica. A Tabela 5.10 mostra a composição percentual estimada pela massa.

Tabela 5.10 - Composição percentual estimada, pela massa.

\begin{tabular}{|l|l|l|l|}
\hline $\begin{array}{l}\text { Numero } \\
\text { Camadas }\end{array}$ & Concreto (\%) & Argamassa (\%) & Cerâmica (\%) \\
\hline 1 & 43,74 & 16,86 & 39,40 \\
\hline 2 & 50,38 & 15,47 & 34,15 \\
\hline 3 & 44,11 & 22,37 & 33,52 \\
\hline 4 & 38,44 & 23,76 & 37,80 \\
\hline 5 & 42,90 & 21,18 & 35,92 \\
\hline 6 & 30,76 & 25,98 & 43,26 \\
\hline 7 & 41,12 & 18,46 & 40,42 \\
\hline 8 & 32,76 & 26,30 & 40,93 \\
\hline
\end{tabular}

A Tabela 5.11 mostra a comparação entre a composição percentual estimada (pela massa) e a composição percentual real. O erro para cada fase, em percentual, foi calculado pela diferença entre a composição estimada e composição real, dividido pela composição real e multiplicado por cem. 
Tabela 5.11 - Composição real e estimada, em porcentagem, pela massa.

\begin{tabular}{|l|l|l|l|l|l|l|l|l|l|}
\hline Camadas & \multicolumn{4}{l}{ Concreto $(\%)$} & \multicolumn{4}{l|}{ Argamassa (\%) } & \multicolumn{2}{l|}{ Cerâmica (\%) } \\
\hline & Real & Estim. & Erro & Real & Estim. & Erro & Real & Estim. & Erro \\
\hline 1 & 42,22 & 43,74 & $+3,60$ & 20,55 & 16,86 & $-17,96$ & 37,23 & 39,40 & $+5,83$ \\
\hline 2 & 42,22 & 50,38 & $+19,33$ & 20,55 & 15,47 & $-24,72$ & 37,23 & 34,15 & $-8,27$ \\
\hline 3 & 42,22 & 44,11 & $+4,48$ & 20,55 & 22,37 & $+8,86$ & 37,23 & 33,52 & $-9,96$ \\
\hline 4 & 42,22 & 38,44 & $-8,95$ & 20,55 & 23,76 & $+15,62$ & 37,23 & 37,80 & $+1,53$ \\
\hline 5 & 42,22 & 42,90 & $+1,61$ & 20,55 & 21,18 & $+3,06$ & 37,23 & 35,92 & $-3,52$ \\
\hline 6 & 42,22 & 30,76 & $-27,14$ & 20,55 & 25,98 & $+26,42$ & 37,23 & 43,26 & $+16,20$ \\
\hline 7 & 42,22 & 41,12 & $-2,60$ & 20,55 & 18,46 & $-10,17$ & 37,23 & 40,42 & $+8,57$ \\
\hline 8 & 42,22 & 32,76 & $-22,41$ & 20,55 & 26,30 & $+27,98$ & 37,23 & 40,93 & $+9,94$ \\
\hline & Media & 40,53 & $-4,01$ & Media & 21,30 & $+3,64$ & Media & 38,17 & $+2,54$ \\
\hline & Desvio & 5,98 & & Desvio & 3,80 & & Desvio & 3,22 & \\
\hline & CV $(\%)$ & 14,76 & & CV $(\%)$ & 17,87 & & CV $(\%)$ & 8,44 & \\
\hline
\end{tabular}

A correlação entre percentual de área e percentual de massa das fases foi realizada segundo os fundamentos da correlação área e volume. Portanto, para a correlação entre área e massa é necessário determinar as massas específicas das fases. Os erros foram considerados baixos e considerou-se a metodologia válida para as três fases analisadas (concreto, argamassa e cerâmica).

\subsubsection{Procedimento para a separação de fases por análise de imagem}

Nesta etapa procurou-se definir um método de caracterização pelo programa que seria aplicado para a seleção das fases concreto, argamassa e cerâmica na análise de imagem.

Os procedimentos para a caracterização foram: a) seleção por segmentação de cores no padrão RGB de todos os grãos, b) geração de máscara da imagem segmentada, c) aplicação do filtro $O P E N$ e gravação da nova máscara, d) gravação por comando das linhas externas ${ }^{17}$, e) ajustes das linhas externas que se façam necessários de forma nãoautomática (manual) ${ }^{18}, \mathrm{f}$ ) criação da terceira máscara em preto e branco dos grãos, g) aplicação do comando RESTRICT DILATION para a retirada do fundo da imagem, h) seleção de forma não-automática (manual) das linhas externas dos grãos referentes a cada fase e gravação das linhas externas das fases, h) geração de máscaras para cada fase a partir das linhas externas das fases e i) calibração do programa (escala) e medição da área.

17 Linhas externas são as linhas de contorno dos grãos. No programa (Menu Measurement, Count/Size, File, Save outlines).

${ }^{18}$ No programa (Area of Interest Tools). 
Destaca-se que na primeira máscara, em preto e branco, os grãos são um conjunto de "pixels" do segundo plano não unidos. Por isso é necessário aplicar o filtro OPEN, eliminando e unificando estes pequenos pontos. A Figura 5.5 mostra o efeito da aplicação do filtro.

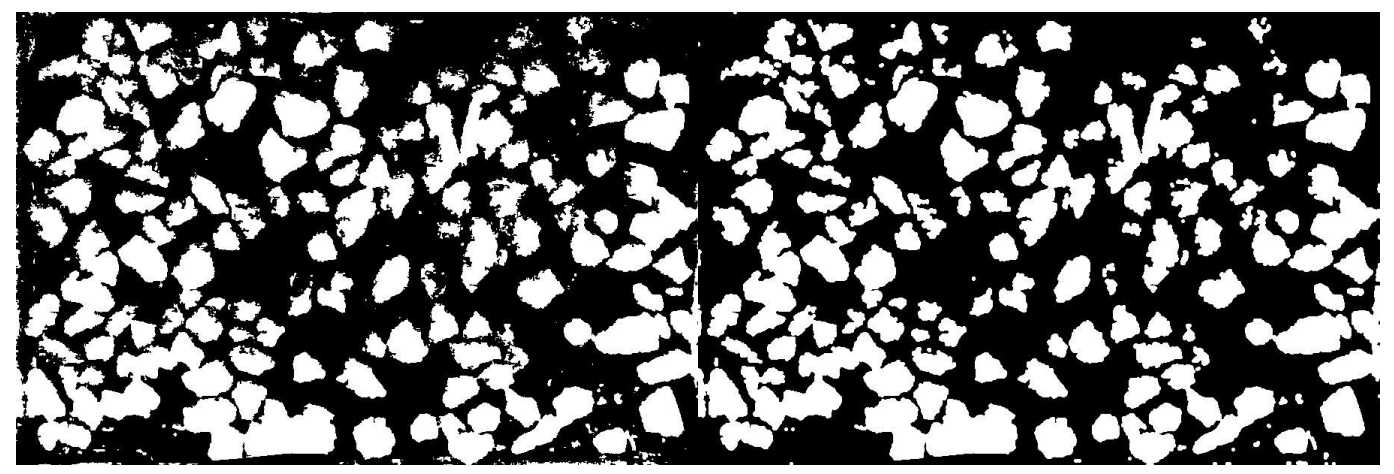

(a)

(b)

Figura 5.5 - Efeito da aplicação do filltro OPEN na imagem, (a) imagem original e (b) imagem com filtro aplicado.

A Figura 5.6 mostra o efeito da aplicação do comando RESTRICT DILATION, em que se retira o fundo da imagem.

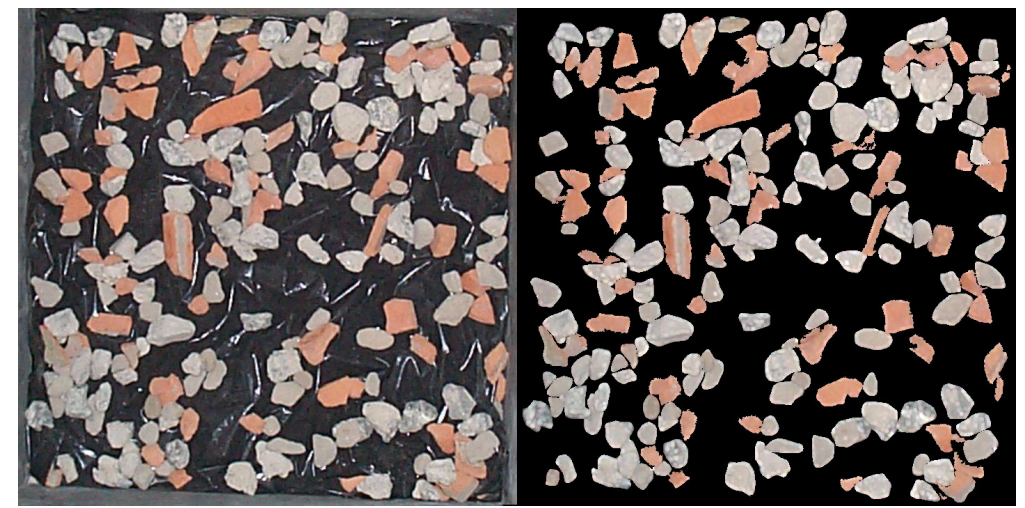

(a)

(b)

Figura 5.6 - Efeito da aplicação do comando RESTRICT DILATION, (a) imagem com fundo e (b) imagem sem fundo.

A seleção dos grãos das fases a partir das linhas externas considera textura e cor, observados visualmente na imagem. 


\subsubsection{Aplicação do método de estudo de composição por análise de imagem}

Provada a correlação entre área e massa e tendo um procedimento que permite separar as fases na imagem, a aplicação em amostras de uma Central de Reciclagem só seria possível se :

a) os valores de massa específica de cada fase da amostra analisada fossem determinados. O único meio de evitar a necessidade de separação das fases é adotar valores médios de massa específica para as fases e analisar se o erro fica dentro de limites aceitáveis.

b) as fases concreto e argamassa fossem separadas por método mais preciso, não utilizando mais observação visual do grão. O item 5.2 discutirá sobre o uso das propriedades absorção de água e massa específica para esta finalidade.

Considerando a necessidade de estudos complementares e a disponibilidade de tempo, não se aplicou o estudo da composição por análise de imagem nas amostras de agregados graúdos de RCD reciclados da Central de Reciclagem de Santo André.

\subsection{Uso da absorção de água e massa específica para a separação das fases concreto e argamassa}

Conforme item 4.2.2, do quarto capítulo, as amostras de laboratório (composições reais) utilizadas neste estudo, tiveram seus valores de absorção de água e massa específica determinados pela NBR 9937 (ABNT, 1987), conforme a Tabela 5.12. Cada amostra continha um teor de concreto e argamassa que foram apresentados na Tabela 4.6.

Tabela 5.12 - Dados de absorção de água e massa específica para as composições reais.

\begin{tabular}{|c|c|c|}
\hline Concreto/ Argamassa & Absorção (\%) & Massa Específica (Kg/m $\left.\mathbf{~}^{\mathbf{3}}\right)$ \\
\hline Amostra A & $4,45^{1}$ & $2,24^{1}$ \\
\hline Amostra B & $9,59^{1}$ & $1,90^{1}$ \\
\hline Amostra C & $11,72^{1}$ & $1,78^{1}$ \\
\hline
\end{tabular}

${ }^{1}$ Valores determinados pela NBR9937 (ABNT, 1987).

A Tabela 5.13 mostra os valores médios de absorção de água e massa específica das fases, obtidos a partir da figura 2.11 do modelo teórico de correlação entre absorção de água e massa específica de concretos e argamassas, desenvolvido com dados da literatura, no terceiro capítulo. 
Tabela 5.13 - Valores médios de absorção de água e massa específica para as fases concreto e argamassa obtidos da literatura (Figura 2.11).

\begin{tabular}{|c|c|c|}
\hline & Absorção (\%) & Massa Específica $\left(\mathbf{K g} / \mathbf{d m}^{\mathbf{3}}\right)$ \\
\hline Concreto & 3,25 & 2,5 \\
\hline Argamassa & 15 & 1,75 \\
\hline
\end{tabular}

Os valores da Tabela 5.12 e Tabela 5.13 foram substituídos no sistema de equações, abaixo identificados como equação 5.1 e equação 5.2, para cada amostra.

$$
\begin{gathered}
\text { Acon } / \arg =\% \text { con } \times \mathrm{Acon}+\% \arg \times \mathrm{A} \arg \\
\delta \text { con } / \arg =\% \text { con } \times \delta \text { con }+\% \arg \times \delta \text { con } \\
\% \text { con }+\% \arg =100
\end{gathered}
$$

sendo:

Acon/arg - absorção de água da fase conjunta de concreto e argamassa (Tabela 5.12).

$\%$ con - percentual em massa da fase concreto.

A con - absorção de água média da fase concreto (Tabela 5.13).

$\%$ arg - percentual em massa da fase argamassa.

A arg - absorção de água média da fase argamassa (Tabela 5.13).

$\delta$ con/arg - massa específica da fase conjunta de concreto e argamassa (Tabela 5.12).

$\delta$ con - massa específica média da fase concreto (Tabela 5.13).

Sarg - massa específica média da fase argamassa (Tabela 5.13).

As duas equações por amostra foram resolvidas e obtiveram-se três composições estimando a porcentagem de concreto e argamassa da composição.

Essas composições estimadas foram comparadas com as composições reais (de laboratório), bem como os erros. Estes foram calculados pela diferença das composições estimadas pela reais, dividido pela composição reais, expresso em porcentagem.

Os erros dos teores de argamassa foram menores quando comparados aos dos teores de concreto para as composições estimadas. Assim, adotaram-se somente os resultados dos teores de argamassa da composição.

Os valores percentuais da fase concreto foram obtidos pela equação 5.3, usando os teores de argamassa determinados anteriormente. A seguir, na Tabela 5.14, serão apresentados os resultados, utilizando as três equações. 
Tabela 5.14 - Composições reais e estimadas, utilizando três equações.

\begin{tabular}{|c|l|c|c|}
\hline \multicolumn{2}{|l|}{ Amostra } & Concreto (\%) & Argamassa (\%) \\
\hline \multirow{3}{*}{ A } & Composição real & 84,3 & 15,7 \\
\cline { 2 - 4 } & Composição estimada & 87,9 & 12,1 \\
\cline { 2 - 4 } & Erro (\%) & 4,27 & 3,6 \\
\hline \multirow{3}{*}{ B } & Composição real & 50 & 50 \\
\cline { 2 - 4 } & Composição estimada & 44 & 56 \\
\cline { 2 - 4 } & Erro (\%) & 12 & 12 \\
\hline \multirow{3}{*}{$\mathbf{C}$} & Composição real & 28,33 & 71,7 \\
\cline { 2 - 4 } & Composição estimada & 26,10 & 73,90 \\
\cline { 2 - 4 } & Erro (\%) & 7,87 & 3,06 \\
\hline
\end{tabular}

Há uma redução significativa do erro quando se adotam as três equações para determinar as composições estimadas, ficando em torno de 10\%. A seguir,na Figura 5.7, será apresentado um gráfico de correlação entre teores das composições estimadas e os teores das composições reais.

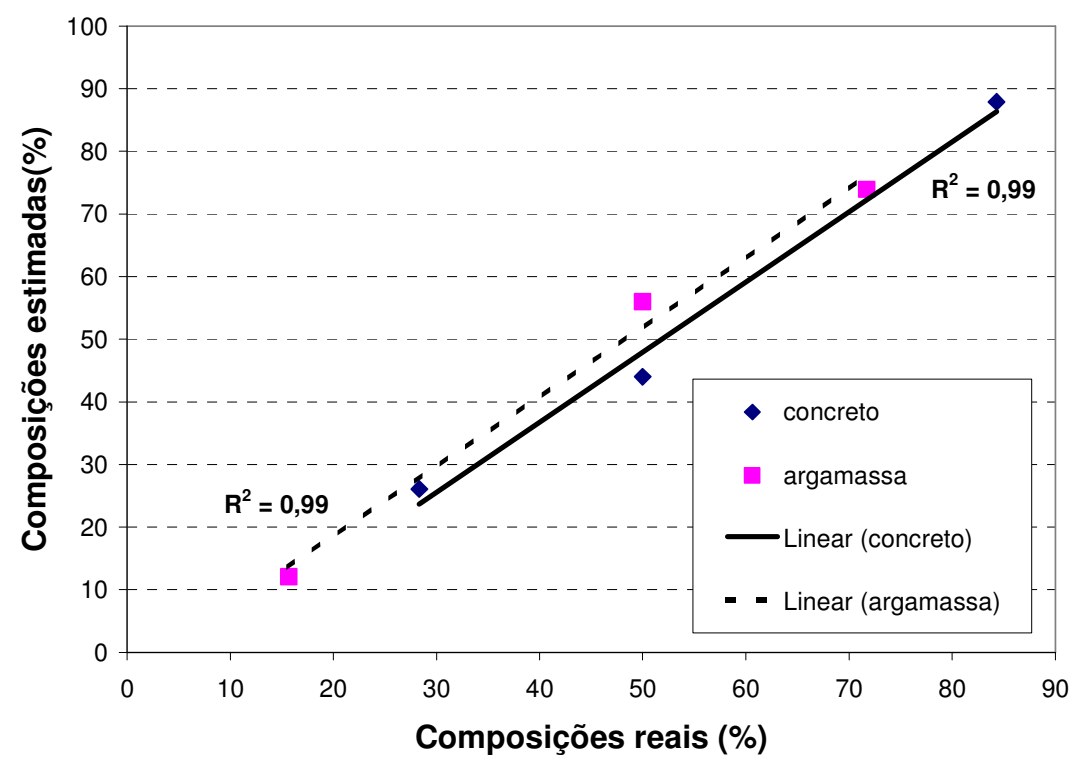

Figura 5.7 - Correlação entre composições reais e estimadas.

Conclui-se que as propriedades absorção de água e massa específica podem ser utilizadas para a determinação da composição concreto e argamassa. No caso específico, a adoção de valores médios de absorção de água retirados da bibliografia forneceu um erro aceitável.

A determinação dos teores de concreto e argamassa, utilizando três equações, foi aplicada no estudo de variabilidade, item 5.3, na determinação da composição dos agregados graúdos de RCD reciclados por separação manual das fases. 


\subsection{Estudo da variabilidade da produção da Central de Reciclagem em Santo André}

As análises estatísticas encontram-se no Anexo. Nele podem-se observar os gráficos de boxes de todas as variáveis da população, bem como a distribuição de frequiências das amostras e a realização de um teste de adequação à distribuição normal dos resultados das amostras.

A não normalidade da distribuição de freqüência das variáveis avaliadas ocorreram para as propriedades seguintes:

a) absorção de água da fase materiais betuminosos;

b) materiais pulverulentos;

c) massa específica da fase cerâmica;

d) granulometria, nas porcentagens retidas no fundo e na peneira de abertura de malha $6,25 \mathrm{~mm}$;

e) composição nas fases materiais betuminosos, cerâmica e outros.

Considera-se, porém, que tal resultado só tenha validade para a propriedade massa específica cerâmica, uma vez que as demais não normalidades ocorreram de propriedades cujos valores são expressos por porcentagem, distribuindo-se provavelmente como funções exponenciais. ${ }^{19}$

\subsubsection{Proporção agregados graúdo $x$ miúdo de $R C D$ reciclados}

Durante o processo de definição e redução das amostras de campo dos agregados graúdos de RCD reciclados, na Central de Santo André, foi montado um procedimento de trabalho representado simplificadamente pelo fluxograma da Figura 4.4 .

No planejamento original, a proporção agregado graúdo/miúdo seria determinada somando-se para ambas frações granulométricas a massa da amostra, do material restante e da contraprova. No entanto as contraprovas de agregados miúdos foram perdidas, não estando disponível a sua massa.

${ }^{19}$ Informações fornecidas pela Prof. Dra. Linda Ho, professora de Estatística do curso de Engenharia de Produção da Escola Politécnica da Universidade de São Paulo. 
Assim, a proporção entre as fases granulométricas será analisada desconsiderando-se as massas da contraprova. As contraprovas de agregado graúdo e miúdo foram compostas de um volume constante retirado do quarteador. No entanto, como as massas unitárias de ambas as fases são diferentes e variáveis, esta simplificação introduz um erro na proporção agregado graúdo-miúdo.

Essas análises são em função da composição e não da produção. As diferenças de volume dos agregados de RCD reciclados, provenientes da produção, não são consideradas. A coleta destes agregados tem volume constante.

A Tabela 5.15 mostra os valores em massa obtidos para os agregados graúdos e miúdos de RCD reciclados em cada amostragem, desconsiderando-se a massa das contraprovas.

Tabela 5.15 - Massa de agregados graúdos e miúdos coletadas em cada amostragem, desconsiderando-se as massas de agregados das contraprovas.

\begin{tabular}{|c|c|c|c|c|c|c|}
\hline Dias & \multicolumn{9}{|l|}{ Agregados graúdos } & \multicolumn{3}{|c|}{ Agregados miúdos } \\
\cline { 2 - 7 } & $\begin{array}{c}\mathbf{1}^{\mathbf{a}} \text { hora } \\
(\mathbf{K g})\end{array}$ & $\begin{array}{c}\mathbf{2}^{\mathbf{a}} \text { hora } \\
(\mathbf{K g})\end{array}$ & $\begin{array}{c}\mathbf{3}^{\mathbf{a}} \text { hora } \\
(\mathbf{K g})\end{array}$ & $\begin{array}{c}\mathbf{1}^{\mathbf{a}} \text { hora } \\
(\mathbf{K g})\end{array}$ & $\begin{array}{c}\mathbf{2}^{\mathbf{a}} \text { hora } \\
(\mathbf{K g})\end{array}$ & $\begin{array}{c}\mathbf{3}^{\mathbf{a}} \text { hora } \\
(\mathbf{K g})\end{array}$ \\
\hline $03 / 02$ & 17,20 & 29,10 & 12,50 & Nd & nd & nd \\
\hline $04 / 02$ & 20,00 & 13,80 & 9,10 & 31,40 & 32,30 & 37,30 \\
\hline $08 / 02$ & 19,30 & 24,20 & 10,70 & 34,30 & 26,30 & 38,80 \\
\hline $09 / 02$ & 26,00 & 25,00 & 21,00 & 25,30 & 24,00 & 25,90 \\
\hline $10 / 02$ & 16,30 & 18,80 & 18,40 & 32,20 & 28,90 & 38,20 \\
\hline $14 / 02$ & 15,50 & 11,90 & 14,50 & 37,30 & 39,60 & 32,00 \\
\hline $15 / 02$ & 19,50 & 16,20 & 18,20 & 29,50 & 32,00 & 35,50 \\
\hline $16 / 02$ & 15,30 & 21,10 & 20,60 & 35,80 & 39,70 & 39,90 \\
\hline $17 / 02$ & 15,30 & 11,50 & 20,10 & 37,50 & 39,50 & 29,00 \\
\hline $21 / 02$ & 25,40 & 8,70 & 12,50 & 22,10 & 39,50 & 36,80 \\
\hline $22 / 02$ & 16,80 & 20,20 & 11,40 & 31,20 & 26,50 & 38,80 \\
\hline $23 / 02$ & 14,40 & 8,20 & 9,30 & 35,50 & 37,20 & 41,60 \\
\hline
\end{tabular}

A Figura 5.8 mostra o teor (\%) médio diário aproximado de agregados graúdos e miúdos. Embora a variação seja expressiva, é possível constatar que existe uma predominância de agregados miúdos sobre os graúdos. 


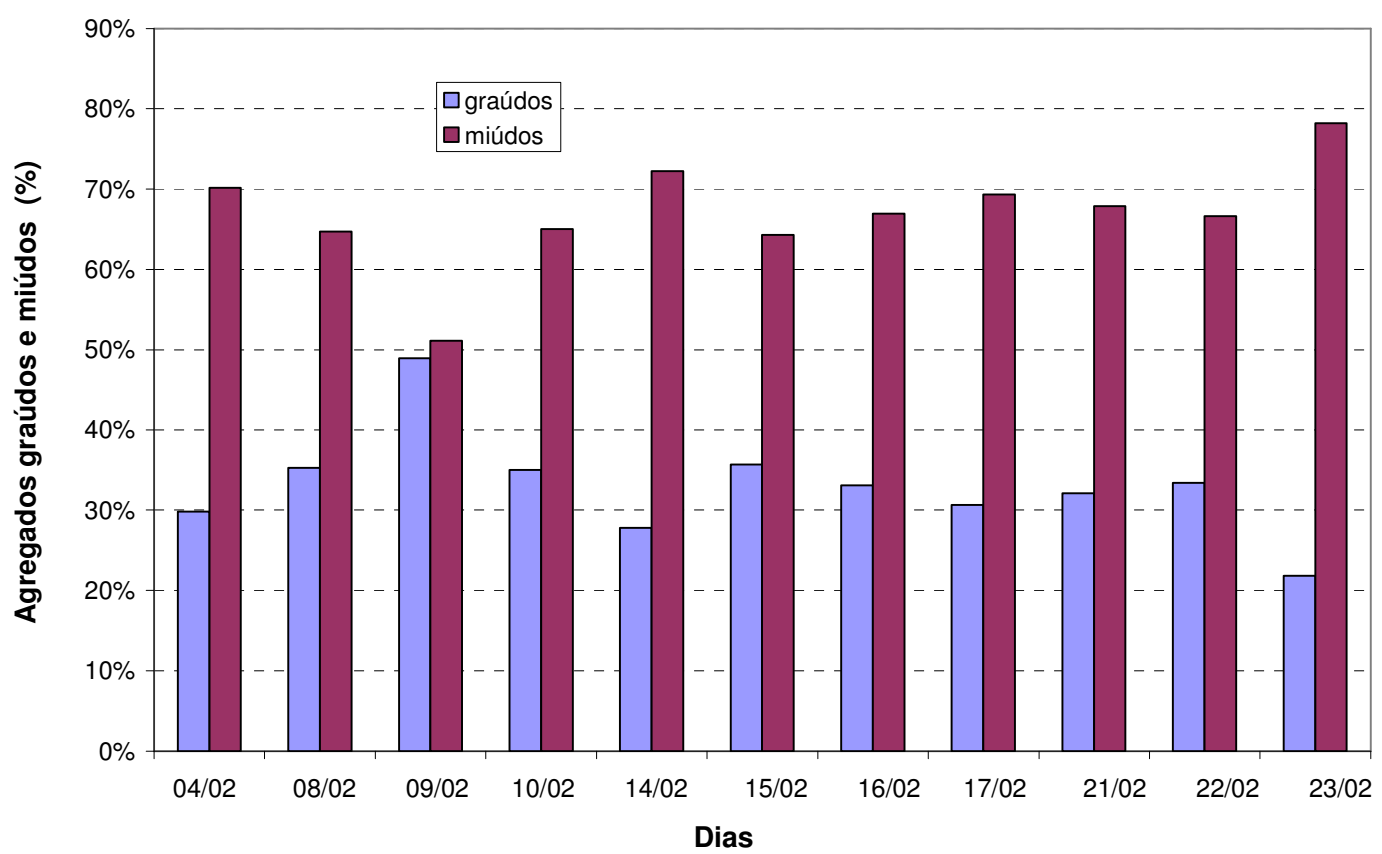

Figura 5.8 - Geração de agregados miúdos e graúdos, em percentual.

O erro causado pela diferença das massas unitárias dos agregados graúdos e miúdos de RCD reciclados aumentaria ainda mais a geração percentual de agregados miúdos, conforme dados de ZORDAN (1997), em que as médias das massas unitárias dos agregados miúdos e graúdos de $\mathrm{RCD}$ reciclados são 1,41 e $1,09 \mathrm{Kg} / \mathrm{dm}^{3}$, respectivamente.

SCHULTMANN et al. (1997) identificaram uma certa quantidade de agregados miúdos já presentes nos resíduos de demolição, mesmo antes da britagem, com valores na ordem de $10 \%$. Este fato pode ser uma das causas para a maior porcentagem de agregados miúdos em relação a graúdos, na reciclagem de resíduos de demolição. Outra causa muito provável é que esta proporção é decorrência da regulagem e do tipo de equipamento de britagem.

\subsubsection{Composição dos agregados graúdos de $R C D$ reciclados}

A composição foi determinada por separação manual das fases, complementadas por medidas de absorção de água e massa específica. Os dados de caracterização das amostras dos agregados graúdos de RCD reciclados indicam significativa variabilidade na composição, conforme a Figura 5.9. Por esta figura 
constatam-se variações significativas entre amostras de um mesmo dia, embora em algum dias os valores tendem a se aproximarem.

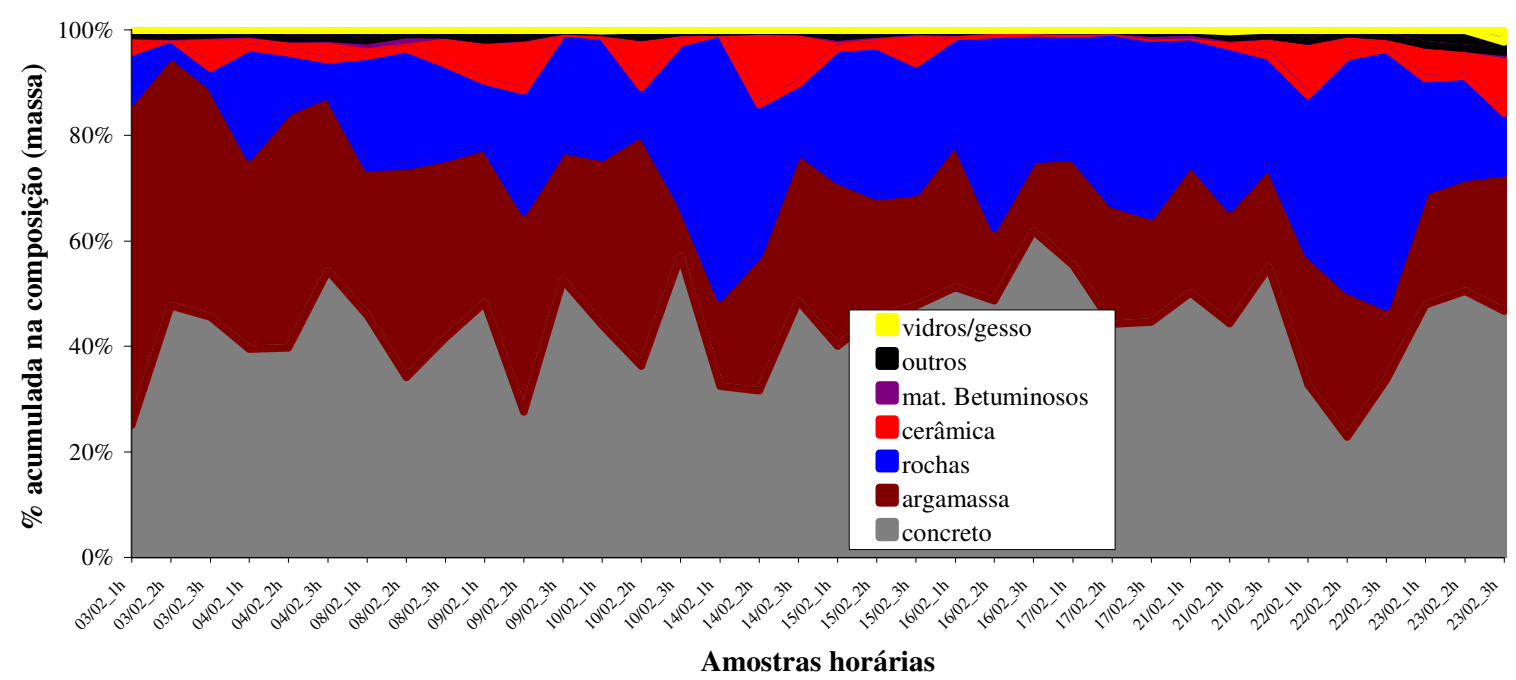

Figura 5.9 - Variabilidade das composições dos agregados graúdos de RCD nas amostras.

A seguir, na Tabela 5.16, temos o resumo dos valores extremos e médios para cada fase da composição, em função das amostras.

Tabela 5.16 - Valores médios e extremos das fases da composição em função das amostras.

\begin{tabular}{|l|c|c|c|c|}
\hline & Concretos & Argamassas & Rochas & Cerâmicas \\
\hline Máximo (\%) & 62 & 61 & 50 & 13 \\
\hline Mínimo (\%) & 23 & 10 & 3 & 0,10 \\
\hline Médio (\%) & 44 & 28 & 23 & 4 \\
\hline CV (\%) & 21 & 39 & 49 & 97 \\
\hline
\end{tabular}

Foram detectadas algumas contaminações ou materiais indesejáveis nas composições. A fase outros (madeira, plásticos, metais, etc) apresentou valor máximo de $3,5 \%$ e fase vidro valor maior que $2 \%$, conforme pode-se observar na Figura 5.10. 


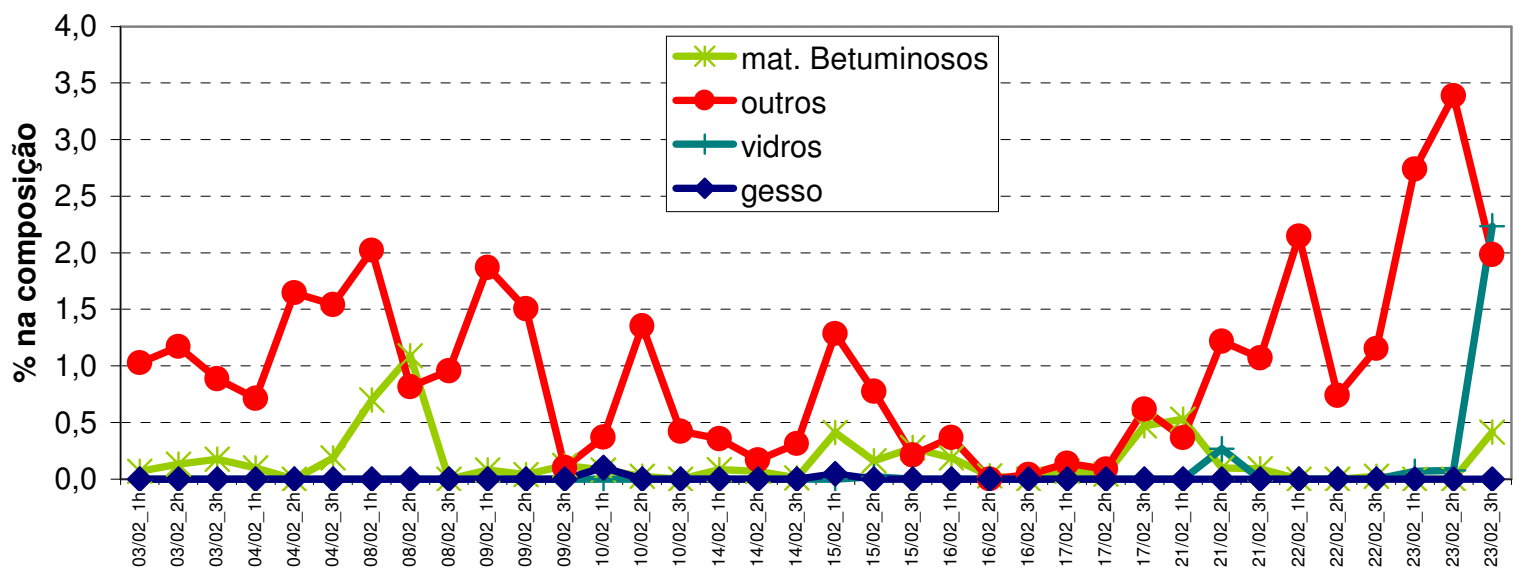

Amostras

Figura 5.10 - Contaminações ou materiais indesejáveis na composição dos agregados graúdos de RCD reciclados, em porcentagem.

A RILEM RECOMMENDATION (1994) indica que a presença de sulfatos deve estar abaixo de 1\%, para uso de agregados de RCD reciclados para concretos. Nenhuma das amostras caracterizadas ultrapassou este limite.

A Figura 5.11 mostra a quantidade acumulada do gráfico de impurezas da composição (materiais betuminosos, vidros e outros) das amostras do estudo (em massa).

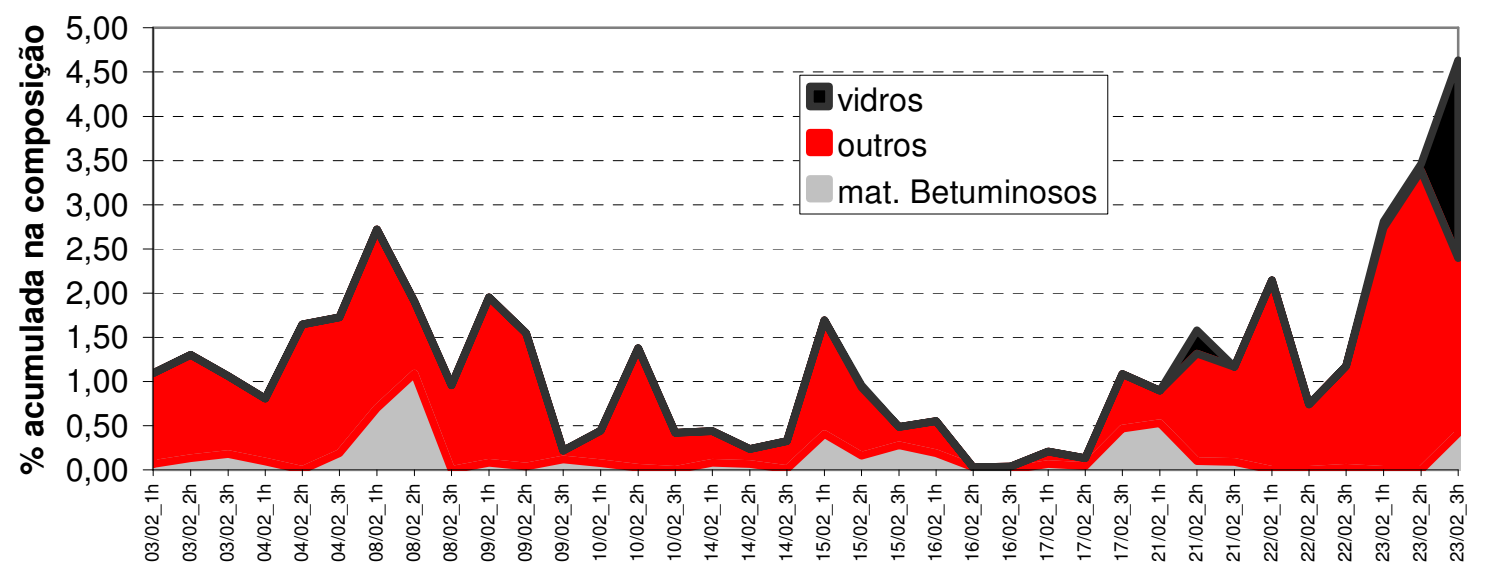

Amostras

Figura 5.11 - Contaminações ou materiais indesejáveis na composição dos agregados graúdos de RCD reciclados, em porcentagem acumulada. 
A RILEM RECOMMENDATION (1994) aponta, conforme o emprego de agregado de RCD reciclado, um total máximo de 1 a 5\% (em massa) de impurezas (vidro, betume, plásticos) toleráveis nos agregados graúdos de RCD reciclados para aplicações em concretos. Para a produção de concretos com limite para impurezas de $1 \%$, existe a necessidade de controle da produção para retirada dessas impurezas.

\subsubsection{Distribuição granulométrica}

A Figura 5.12 mostra as curvas limites que definem a variação das curvas granulométricas de todas as amostras. Percebem-se variações consideráveis para as peneiras de abertura de malha $6,3 \mathrm{~mm}, 4,8 \mathrm{~mm}$ e no fundo, sendo que a maior variação foi o percentual passante acumulado da peneira de abertura de malha $4,8 \mathrm{~mm}$.

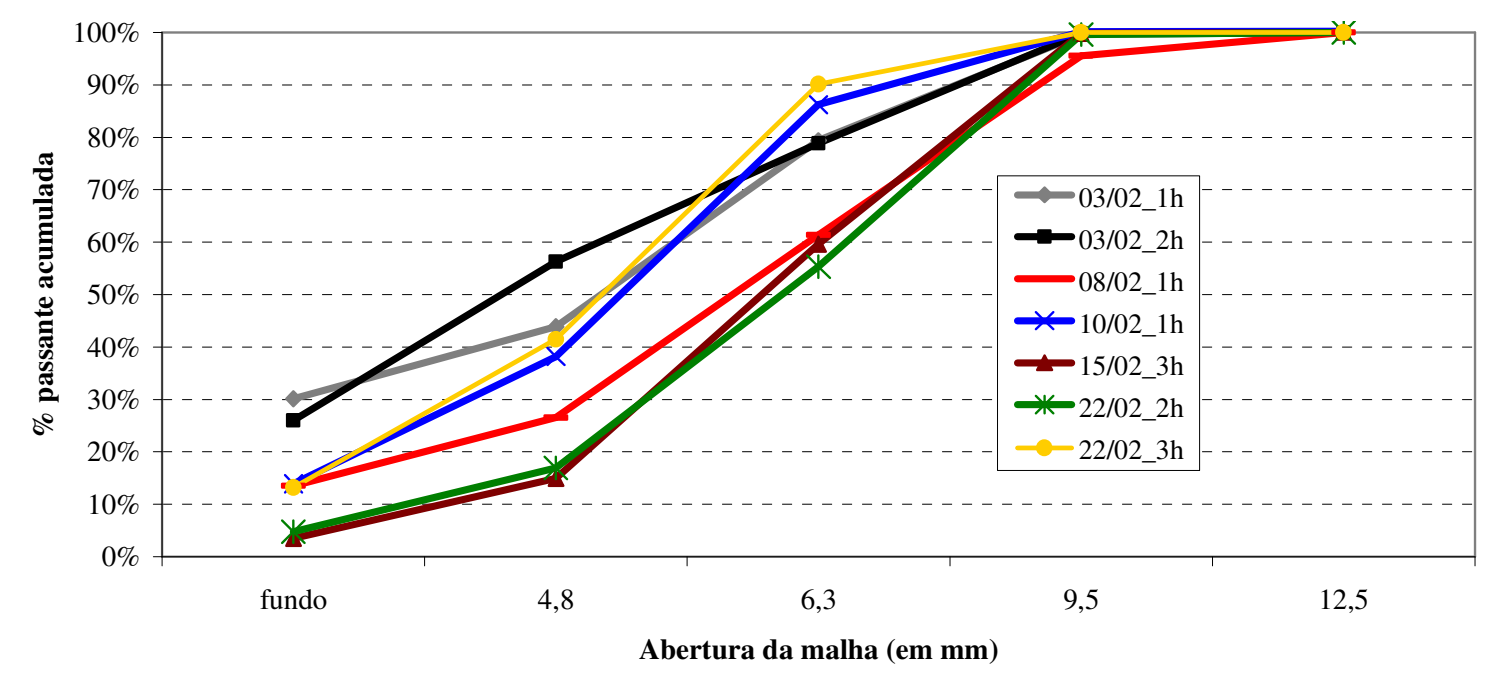

Figura 5.12 - Curvas granulométricas limites das amostras.

A Tabela 5.17 fornece os valores máximos, mínimos e médios dos percentuais passantes acumulados em função da abertura da peneira. As malhas de maiores aberturas apresentam coeficiente de variação comparativamente menor.

Tabela 5.17 - Valores médios e extremos dos percentuais retidos acumulados da granulometria em função das peneiras para as amostras.

\begin{tabular}{|l|c|c|c|c|}
\hline $\begin{array}{c}\text { Abertura das } \\
\text { peneiras }\end{array}$ & Fundo & $\mathbf{4 , 8 m m}$ & $\mathbf{6 , 2 5 m m}$ & $\mathbf{9 , 5 m m}$ \\
\hline Máximo & $30 \%$ & $56 \%$ & $90 \%$ & $100 \%$ \\
\hline Mínimo & $3,5 \%$ & $15 \%$ & $55 \%$ & $95,5 \%$ \\
\hline Médio & $11 \%$ & $30 \%$ & $74 \%$ & $99,7 \%$ \\
\hline CV (\%) & $63 \%$ & $32 \%$ & $11 \%$ & $1 \%$ \\
\hline
\end{tabular}


$\mathrm{O}$ alto percentual de material retido no fundo pode ter sido causado pelo sistema de peneiramento improvisado nas instalações da Central de Reciclagem e pelos materiais pulverulentos que acompanham os grãos de agregados graúdos de RCD reciclados.

Em relação às curvas granulométricas das amostras, nota-se que existe variabilidade da granulometria entre amostras de um mesmo dia, conforme mostra a Figura 5.13.

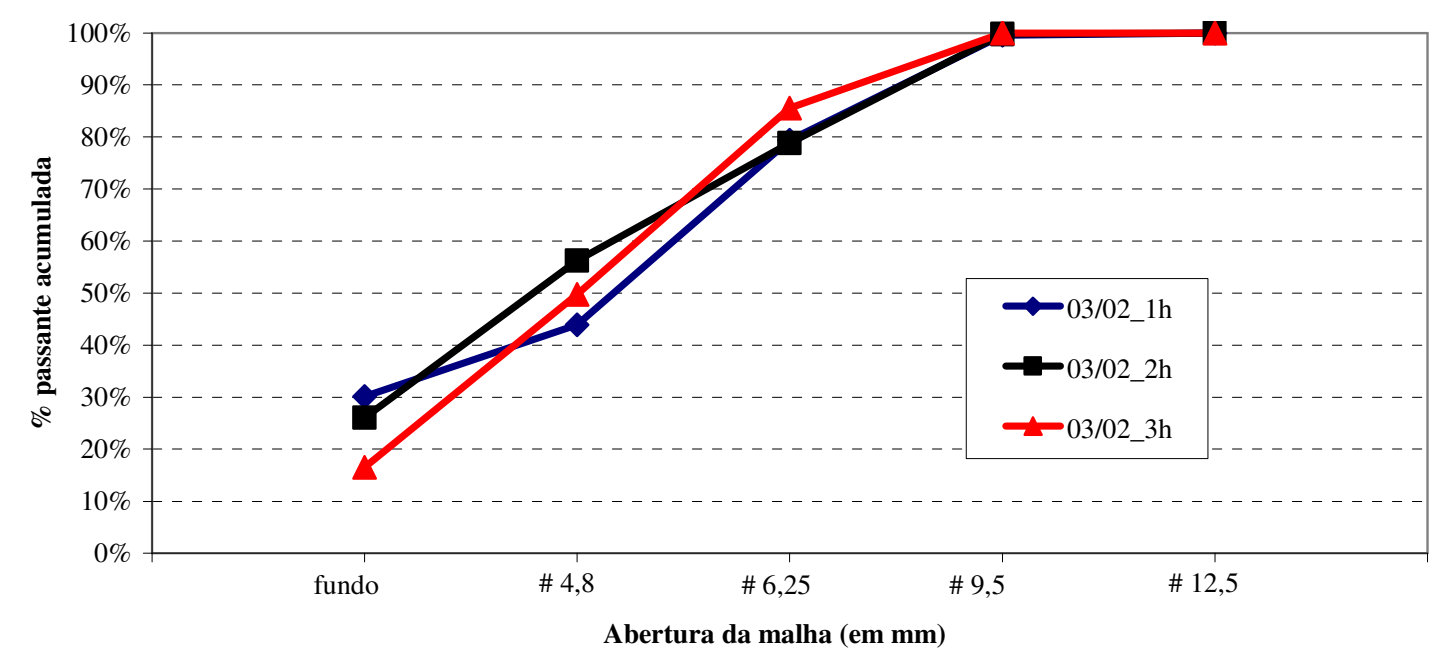

Figura 5.13 - Curvas granulométricas horárias dos dias 03/02.

Existem também curvas granulométricas das amostras de um mesmo dia que são bem semelhantes entre si, conforme a Figura 5.14.

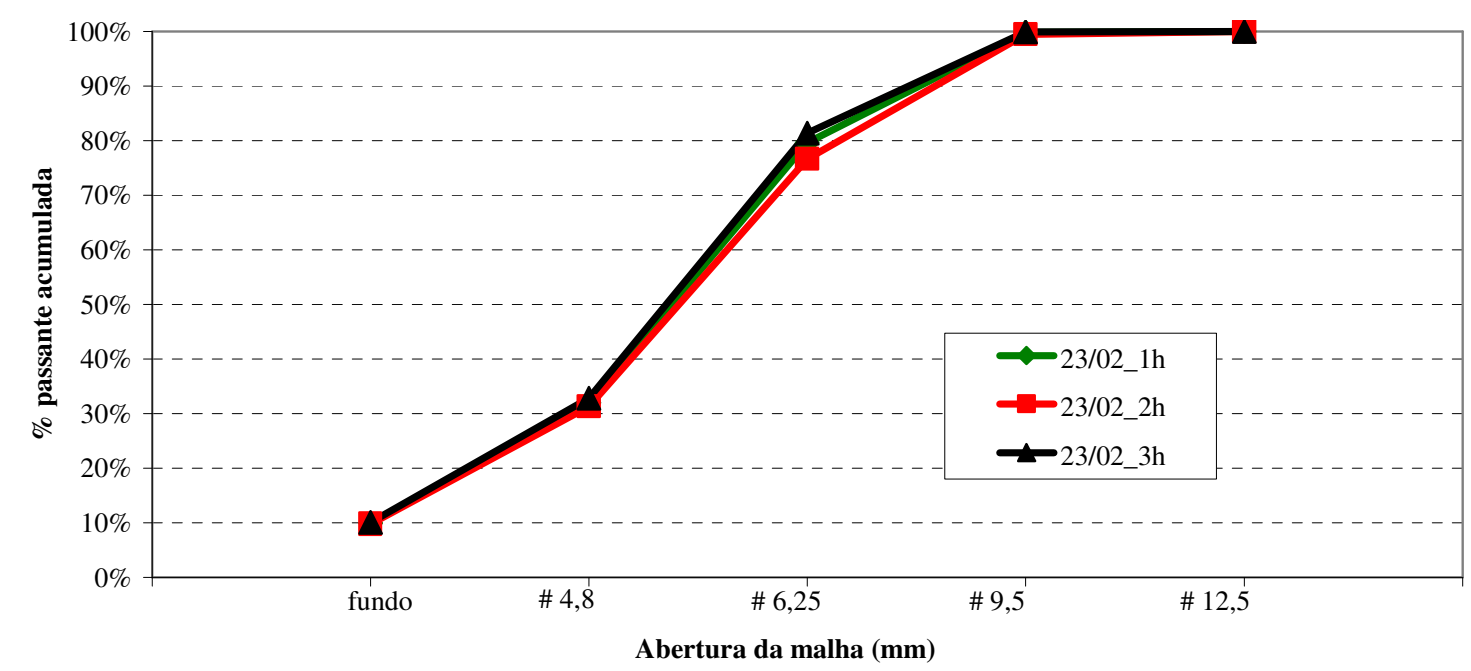

Figura 5.14 - Curvas granulométricas horárias do dia 23/02. 


\subsubsection{Materiais pulverulentos}

Procurando-se também avaliar a variabilidade dessa propriedade, a Figura 5.15 apresenta os teores de materiais pulverulentos obtidos para as amostras. Prevalece a heterogeneidade na propriedade.

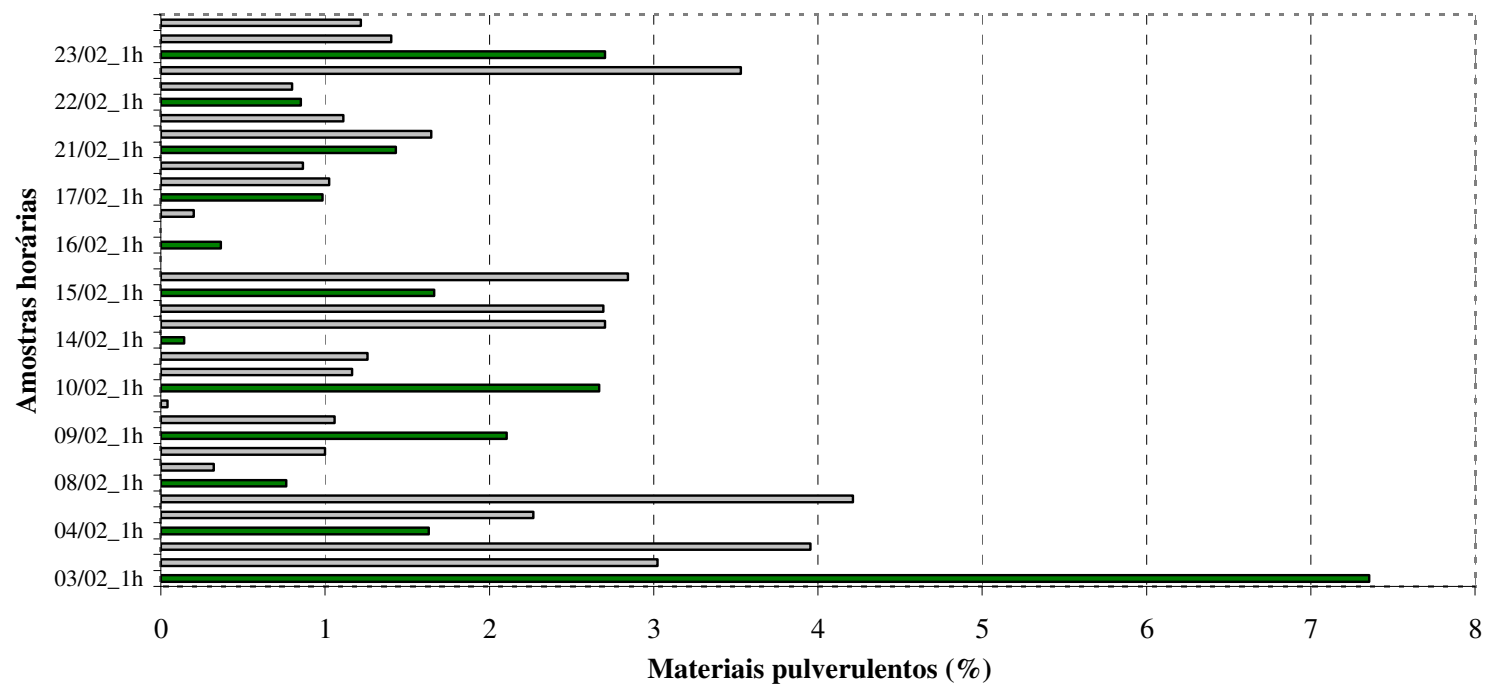

Figura 5.15 - Teores de materiais pulverulentos para as amostras.

Considerando a RILEM RECOMMENDATION (1994), para emprego de agregados graúdos de RCD reciclados em concretos, o teor máximo permitido de materiais pulverulentos fica entre 2 e $3 \%$, dependendo do tipo de emprego do agregado.Analisando a Figura 5.15, 12 das 36 amostras não atendem a especificação de 2\%. Para este caso, $33 \%$ das amostras deveriam ser descartadas num controle. $\mathrm{O}$ controle desta característica deverá exigir equipamentos adicionais, quando se visar ao emprego em concreto.

A Tabela 5.18 mostra os valores máximo, mínimo e médio da propriedade, bem como o coeficiente de variação.

Tabela 5.18 - Valores extremos e médio para o teor de materiais pulverulentos.

\begin{tabular}{|l|c|}
\hline & Amostras \\
\hline Máximo & $7,36 \%$ \\
\hline Mínimo & $0 \%$ \\
\hline Médio & $1,69 \%$ \\
\hline CV (\%) & $89 \%$ \\
\hline
\end{tabular}


5.3.5 Massa Específica e Absorção de água dos agregados graúdos de RCD reciclados para as fases da composição.

A Figura 5.16 mostra os valores de absorções, conforme a norma NBR 9937 (ABNT, 1987), por fase das amostras obtidas por fases dos agregados graúdos de RCD reciclados em ensaios de laboratório.

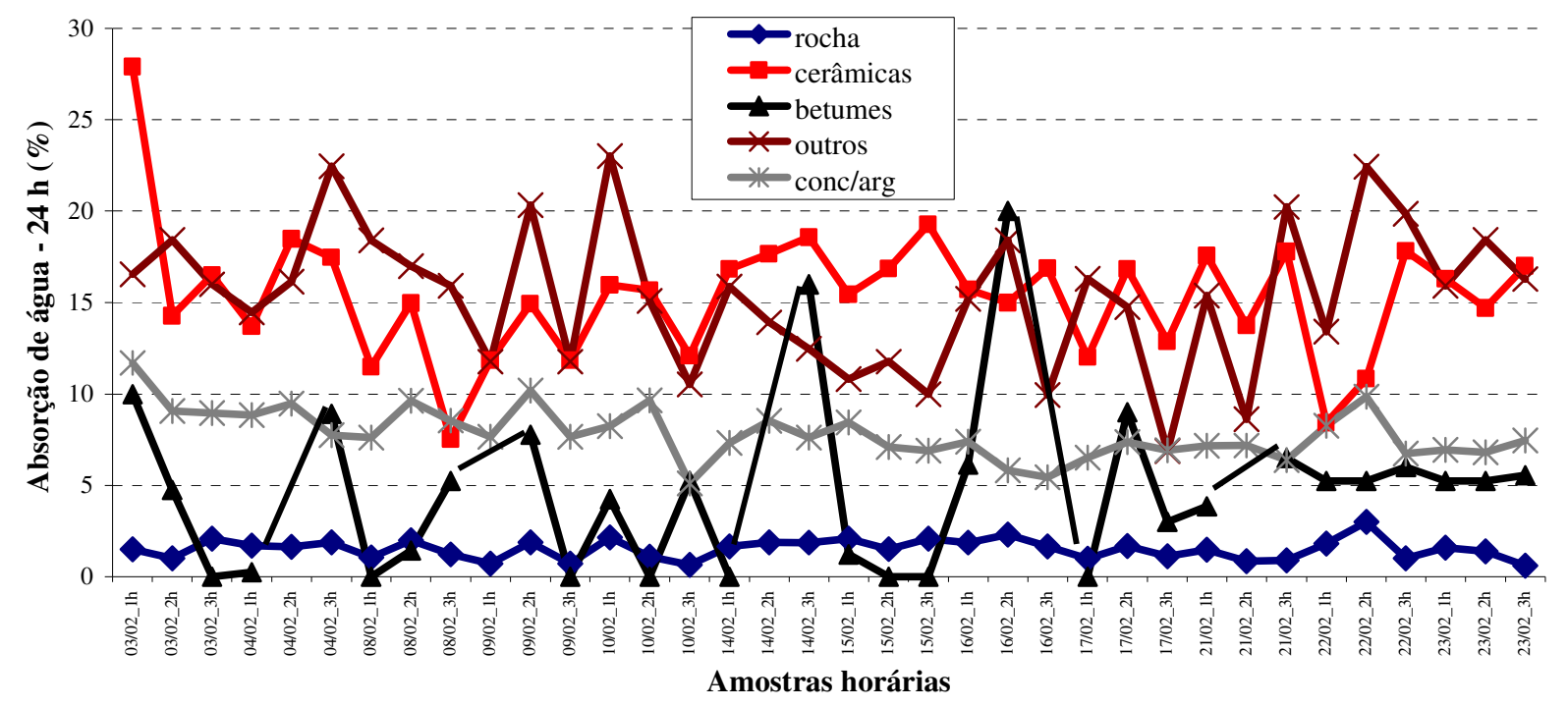

Figura 5.16 - Absorção de água por imersão 24 horas, em porcentagem, por fases nas amostras dos agregados graúdos de $\mathrm{RCD}$ reciclados.

A Tabela 5.19 mostra os valores máximos, mínimos, médios e os coeficientes de variação da absorção de água por imersão 24 horas para as fases das amostras.

Tabela 5.19 - Valores extremos e médio para absorção de água por imersão 24 horas, em porcentagem.

\begin{tabular}{|l|l|l|l|l|l|}
\hline \multirow{2}{*}{} & \multicolumn{5}{|c|}{ Fase das amostras } \\
\cline { 2 - 6 } & $\begin{array}{l}\text { Concreto/ } \\
\text { Argamassa }\end{array}$ & Rochas & Cerâmica & $\begin{array}{l}\text { Materiais } \\
\text { Betuminosos }\end{array}$ & Outros \\
\hline Máximo & 11,70 & 3,01 & 27,91 & 20,00 & 23,01 \\
\hline Médio & 7,84 & 1,52 & 15,36 & 4,71 & 15,41 \\
\hline Mínimo & 5,11 & 0,61 & 7,54 & 0,00 & 6,87 \\
\hline CV (\%) & 17,73 & 35,92 & 23,05 & 100 & 25,64 \\
\hline
\end{tabular}

Nota-se variabilidade nas medidas de absorções de uma mesma fase. Percebese que para as fases cerâmica e concreto/argamassa são mais estáveis. A estabilidade da fase concreto/argamassa favorece o emprego do método baseado nas propriedades de 
absorção de água e massa específica para identificar os teores de concreto e argamassa da composição. As fases materiais betuminosos, rochas e outros (madeira, metais, etc) podem apresentar problemas de medição pelo método adotado.

A Figura 5.17 apresenta os resultados de massa específica para as diversas fases presentes nos agregados graúdos de RCD reciclados para as amostras.

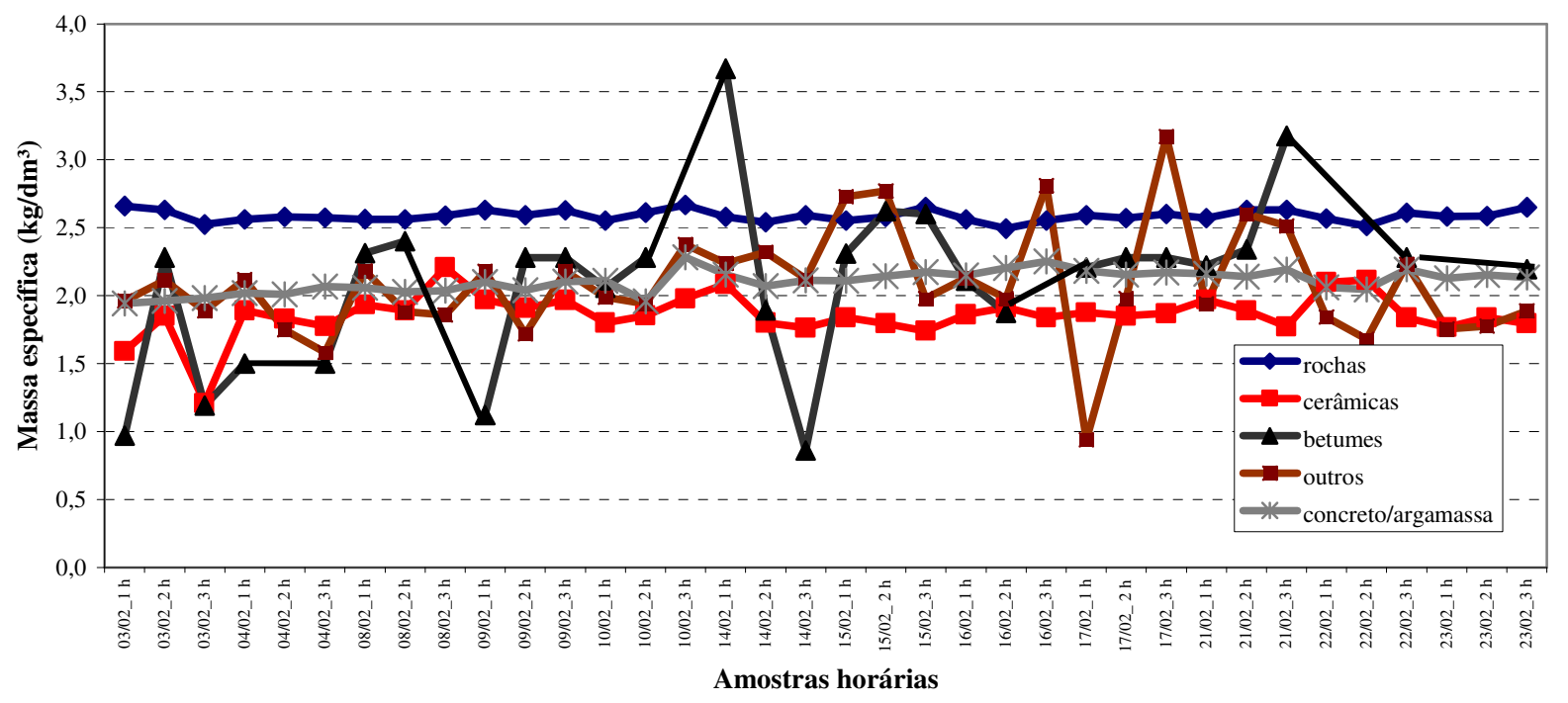

Figura 5.17 - Massa específica por fases nas amostras dos agregados graúdos de RCD reciclados.

A seguir, na Tabela 5.20, mostram-se os valores extremos e médios das fases nas amostras, para a propriedade massa específica.

Tabela 5.20 - Valores extremos e médios para massa específica, em função das fases da amostras.

\begin{tabular}{|l|l|l|l|l|l|}
\hline \multirow{2}{*}{} & \multicolumn{5}{|c|}{ Fases das amostras } \\
\cline { 2 - 6 } & $\begin{array}{l}\text { Concreto } \\
\text { Argamassa }\end{array}$ & Rochas & Cerâmicas & $\begin{array}{l}\text { Materiais } \\
\text { Betuminosos }\end{array}$ & Outros \\
\hline Máximo & 2,28 & 2,67 & 2,21 & 3,67 & 3,17 \\
\hline Médio & 2,10 & 2,59 & 1,86 & 2,11 & 2,09 \\
\hline Mínimo & 1,94 & 2,49 & 1,21 & 0,86 & 0,94 \\
\hline CV (\%) & 3,88 & 1,60 & 8,7 & 28,92 & 19,46 \\
\hline
\end{tabular}

Para a massa específica, as fases concreto/argamassa, rochas e cerâmicas ficaram mais estáveis. A estabilidade da fase concreto/argamassa favorece o emprego do método baseado nas propriedades de absorção de água e massa específica para identificar os teores de concreto e argamassa da composição. 


\subsection{6 Índice de forma}

A Figura 5.18 mostra os valores de índice de forma dos agregados graúdos de RCD reciclados para as amostras. Nota-se aqui também a presença de variabilidade.

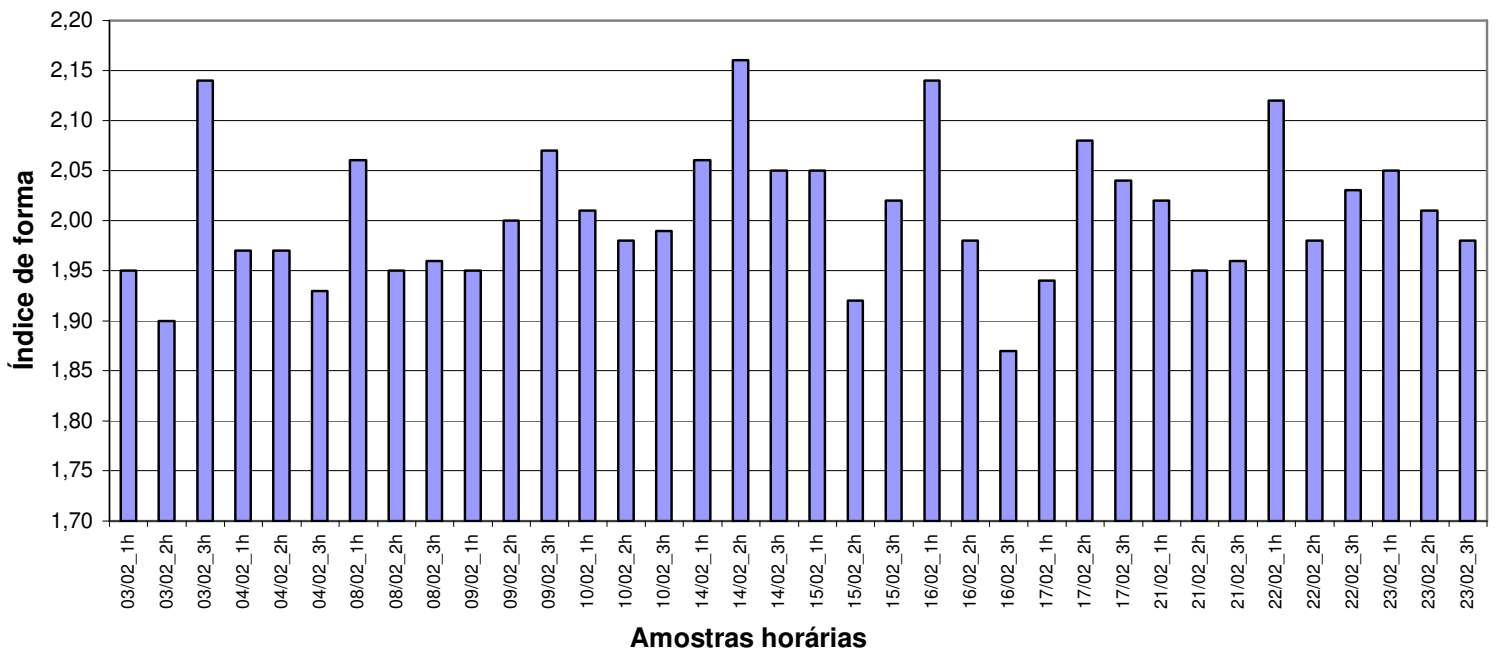

Figura 5.18 - Valores de índice de forma para as amostras.

A Tabela 5.21 mostra os valores extremos e médio para a propriedade nas amostras.

Tabela 5.21 - Valores extremos e médios para o Índice de forma nas amostras.

\begin{tabular}{|l|c|}
\hline & Amostras \\
\hline Máximo & 2,16 \\
\hline Mínimo & 1,87 \\
\hline Médio & 2,01 \\
\hline CV (\%) & $3 \%$ \\
\hline
\end{tabular}

\subsubsection{Homogeneização da composição}

Considerando-se que a redução da variabilidade dos agregados graúdos de $\mathrm{RCD}$ reciclados tornaria mais fácil seu emprego, este item procura investigar qual o período de tempo mais adequado para a formação de pilhas de homogeneização. As composições médias diárias foram obtidas pela média entre as amostras do dia.

A Tabela 5.22 analisa o período de tempo para a formação das pilhas segundo valores máximos, mínimos e os coeficientes de variação para as quatro principais fases das composições (concreto, argamassa, rochas e cerâmica). 
Tabela 5.22 - Variação da composição das pilhas de homogeneização em função do seu tempo de formação.

\begin{tabular}{|l|c|c|c|c|c|c|c|c|c|}
\hline \multirow{2}{*}{$\begin{array}{l}\text { Fases da } \\
\text { Composição }\end{array}$} & \multicolumn{3}{|c|}{ Pilhas horárias } & \multicolumn{3}{c|}{ Pilhas diárias } & \multicolumn{3}{c|}{ Pilhas em 2 dias } \\
\cline { 2 - 11 } & CV & $\begin{array}{c}\text { Máximo } \\
(\%)\end{array}$ & $\begin{array}{c}\text { Mínimo } \\
(\%)\end{array}$ & $\begin{array}{c}\text { CV } \\
(\%)\end{array}$ & $\begin{array}{c}\text { Máximo } \\
(\%)\end{array}$ & $\begin{array}{c}\text { Mínimo } \\
(\%)\end{array}$ & $\begin{array}{c}\text { CV } \\
(\%)\end{array}$ & $\begin{array}{c}\text { Máximo } \\
(\%)\end{array}$ & $\begin{array}{c}\text { Mínimo } \\
(\%)\end{array}$ \\
\hline Concreto & 21 & 61,90 & 22,81 & 15 & 53,93 & 29,75 & 10 & 49,23 & 39,04 \\
\hline Argamassa & 39 & 61,38 & 10,08 & 33 & 50,95 & 18,29 & 32 & 44,57 & 21,52 \\
\hline Rochas & 49 & 50,26 & 3,09 & 40 & 41,12 & 5,30 & 33 & 29,20 & 9,07 \\
\hline Cerâmica & 97 & 13,86 & 0,10 & 63 & 7,93 & 0,43 & 57 & 6,64 & 1,16 \\
\hline
\end{tabular}

Considerando-se os teores de concreto, argamassa e rocha nas composições, os coeficientes de variação ainda são altos para os períodos de tempo de formação de pilha estudados. Recomendam-se períodos superiores a 2 dias para a formação de pilhas de homogeneização para a Central de Reciclagem de Santo André. Em outras centrais, esse tempo de formação pode se alterar em função da origem dos RCD recebidos.

\subsubsection{Correlação entre composição e propriedades}

Os resultados de regressões entre teores de argamassa e geração de agregados miúdos de RCD reciclados (em porcentagem) e entre teores de concreto e geração de agregados graúdos de RCD reciclados (em porcentagem) não foram satisfatórios.

A seguir, serão apresentadas outras correlações com a composição dos agregados graúdos de RCD reciclados.

\subsubsection{Absorção de água e massa específica.}

Neste item serão investigadas a influência das diferentes fases na propriedade média dos agregados produzidos. As propriedades médias serão calculadas de forma ponderada de acordo com a equação 5.4. A influência das diferentes fases será investida através de regressões.

Abstotal $=$ Abscon $/ \arg \times \%$ con $/ \arg +$ Absrocha $\times \%$ rocha + Abscer $\times \%$ cer $+\ldots$ (eq.5.4)

A Figura 5.19 mostra a absorção de água média das amostras dos agregados. A Figura 5.20 demonstra que o valor de absorção de água decresce linearmente com o aumento dos teores das fases de menor absorção: concreto e rochas. 


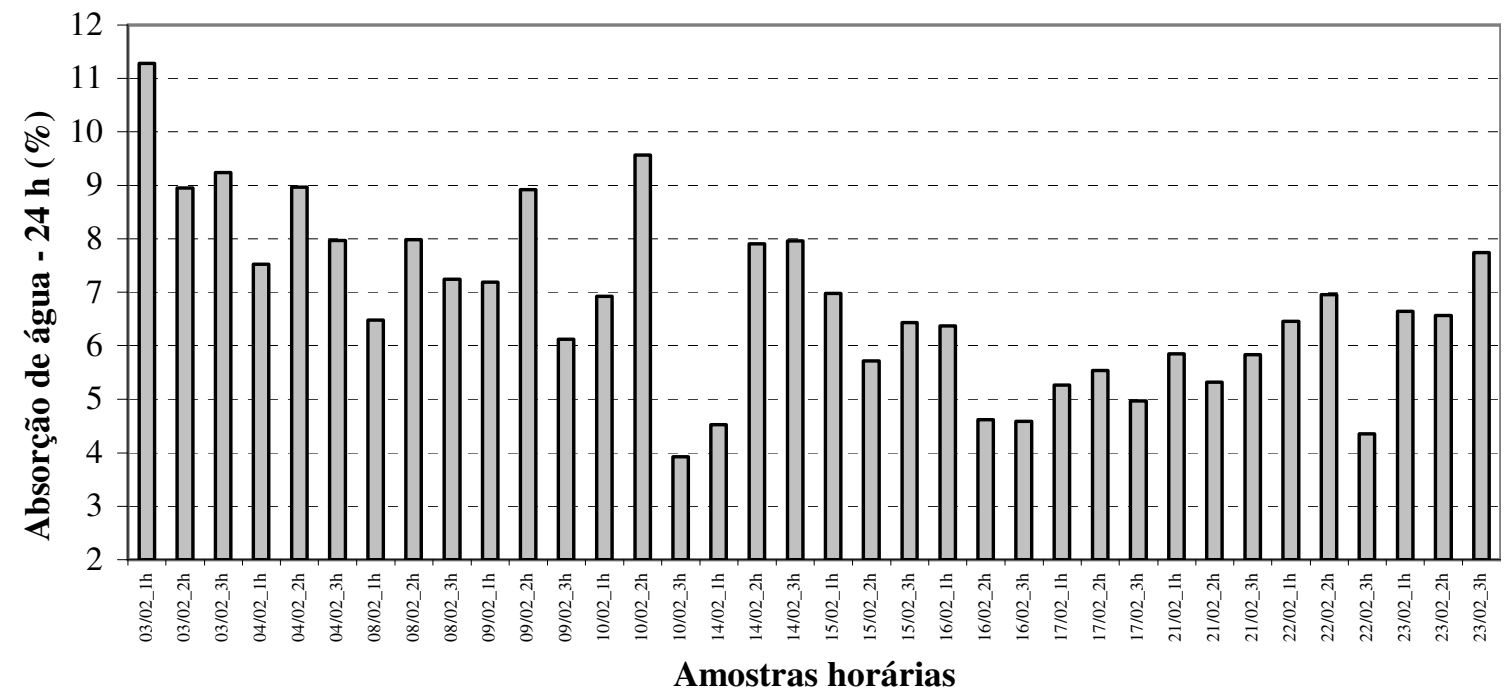

Figura 5.19 - Valores de absorção média de água por imersão em 24 horas das amostras.

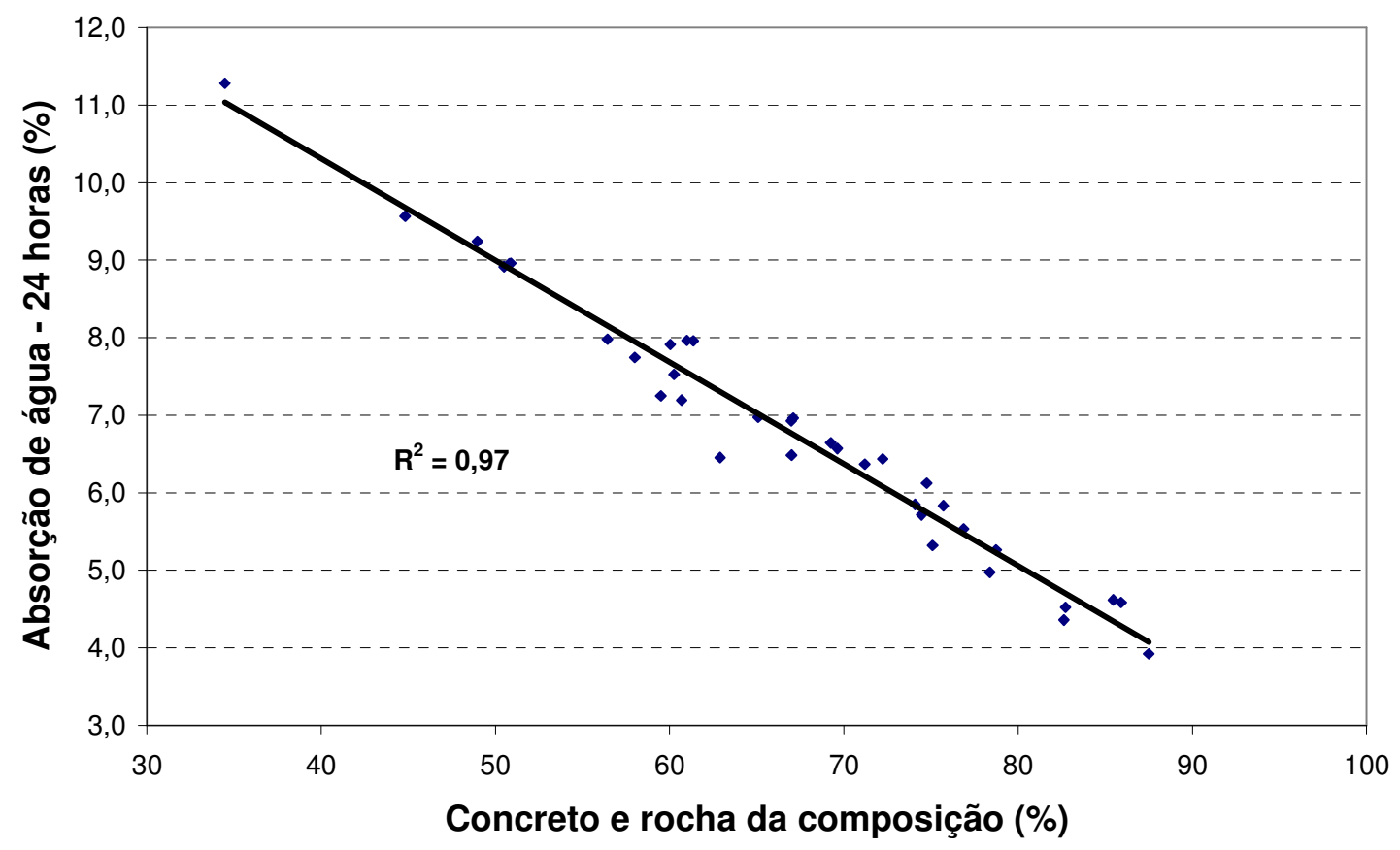

Figura 5.20 - Regressão linear entre teores de concreto e rocha da composição com os valores de absorção média de água.

$\mathrm{O} \mathrm{R}^{2}$ na Figura 5.20 é definido como coeficiente de determinação. Este coeficiente representa a proporção da variação total da variável dependente, conforme LAPPONI (1997). Ainda segundo o autor, este valor equivale ao quadrado do coeficiente de correlação. O coeficiente de correlação, conforme sugestão do autor, é o 
mais indicado para avaliar a força da relação entre variáveis. Sendo assim, considera-se a correlação obtida na Figura 5.20 significativa.

A Figura 5.21 mostra os valores de massa específica média dos agregados graúdos de RCD reciclados, para as amostras. Conforme observado na Figura 5.22, a massa específica cresce na razão direta do aumento dos teores de concreto e rochas.

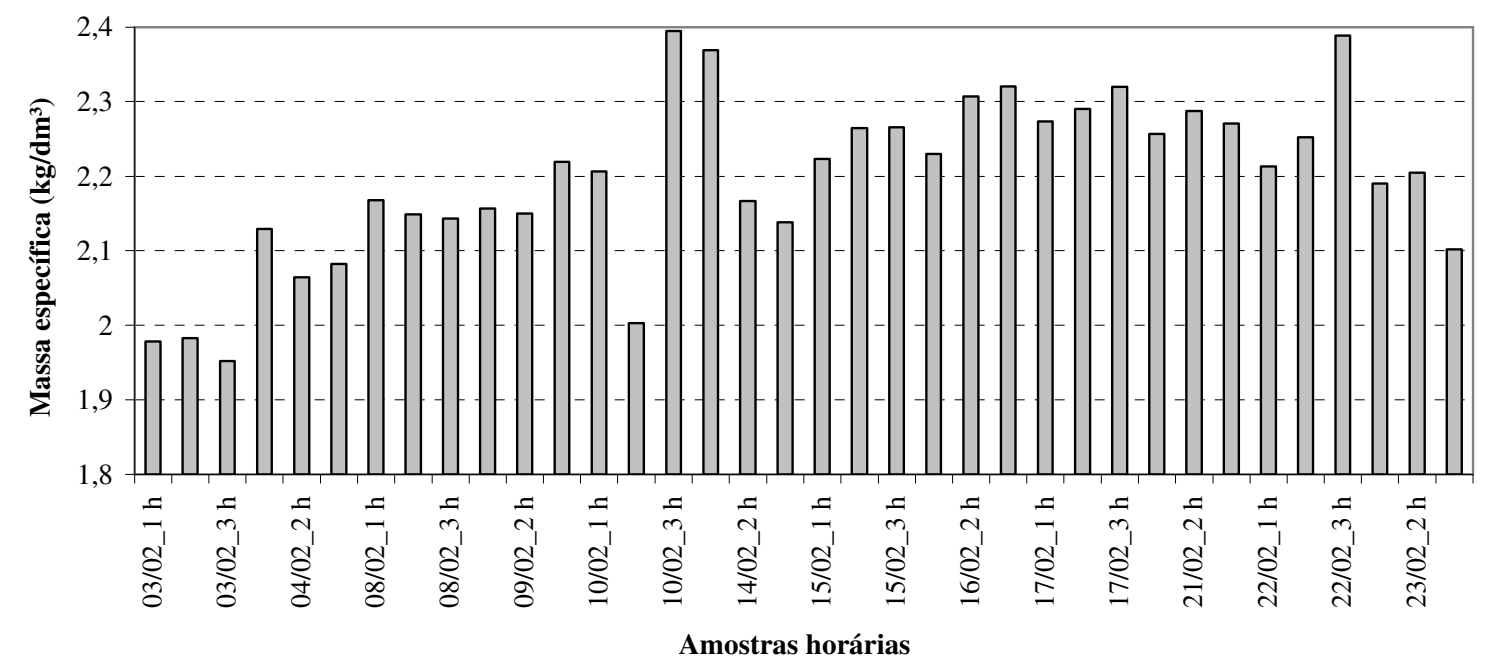

Figura 5.21 - Valores de massa específica média dos agregados graúdos de RCD reciclados, para as amostras.

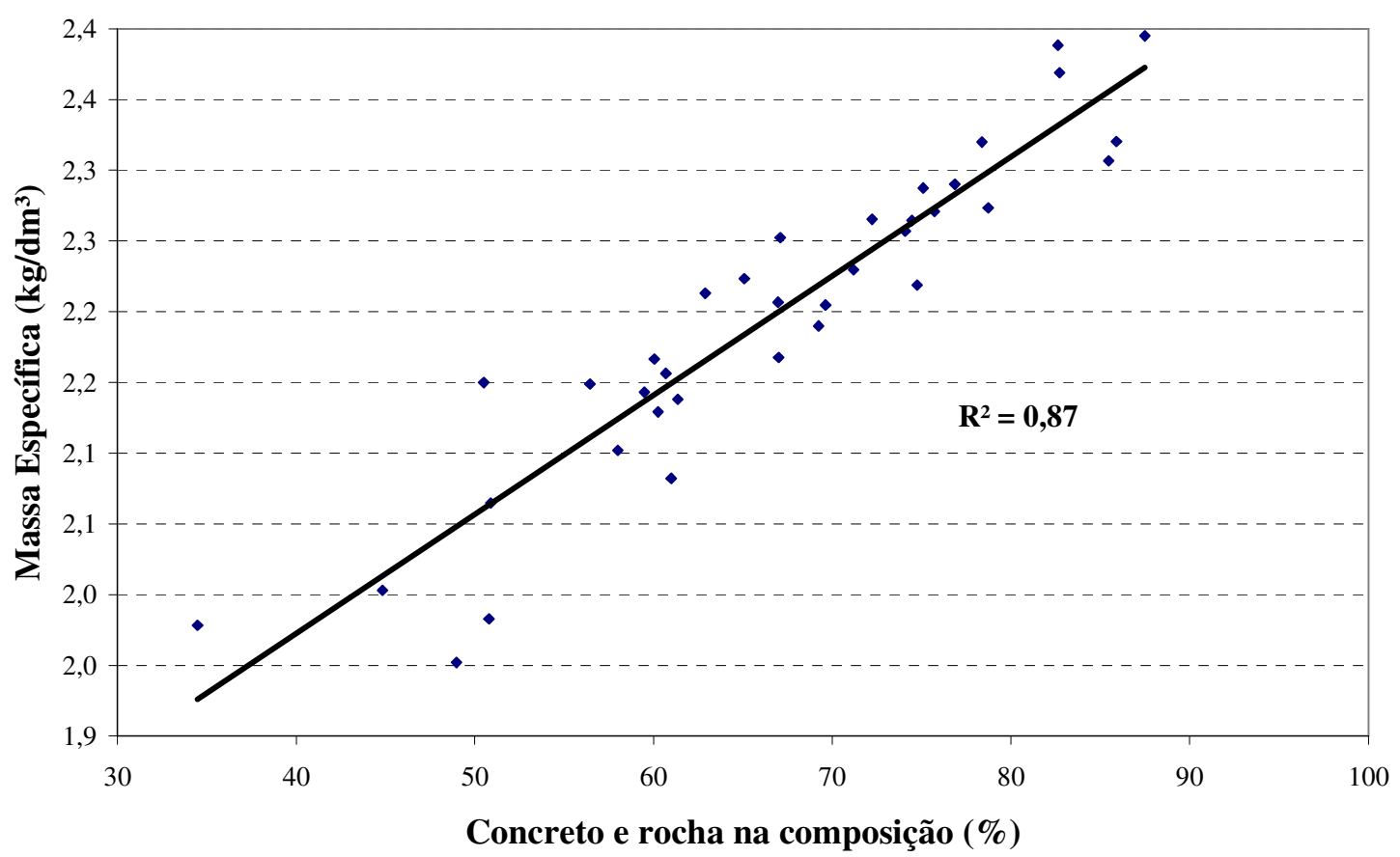

Figura 5.22 - Regressão linear entre teores de rocha e concreto e valores de massa específica média para as amostras. 


\subsubsection{Granulometria}

Procurou-se correlacionar a porcentagem de argamassa da composição com o percentual retido no fundo para as amostras. A porcentagem de argamassa da composição é a variável independente. A Figura 5.23 mostra o coeficiente de determinação obtido.

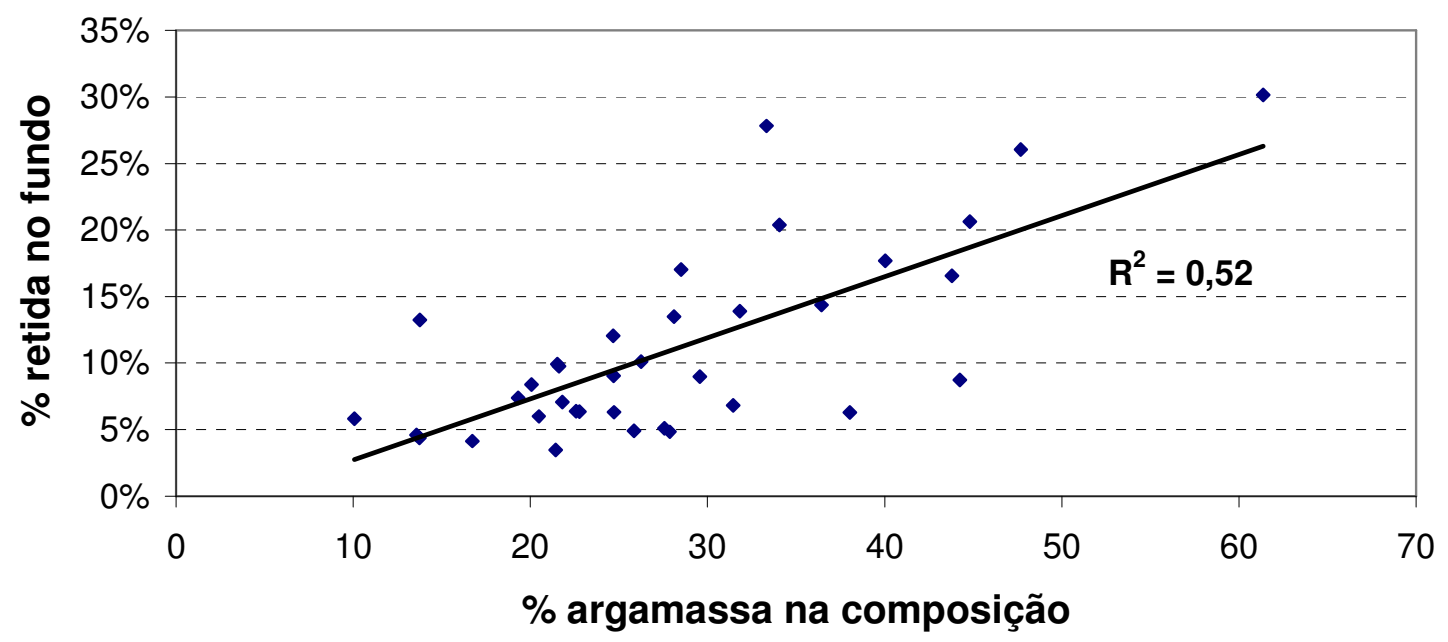

Figura 5.23 - Regressão linear da porcentagem do fundo e a porcentagem de argamassa da composição das amostras.

Percebe-se que o coeficiente de correlação é a raiz deste valor, mesmo não se retirando os valores espúrios, que pode ser feita com até $10 \%$ da amostra, conforme WAENY (1992). Sendo assim, aceitou-se a correlação com valor de $72 \%$.

A regressão entre os teores de argamassa e teor de materiais pulverulentos não apresentou resultados que indiquem correlação entre as variáveis. 


\section{CONCLUSÕES}

É inegável a natureza mineral do material predominante na composição dos resíduos de construção e demolição, mesmo nas suas duas fontes potenciais: construção e demolição. A britagem da parcela mineral não-orgânica ${ }^{20}$ visando a produção de agregados, é uma eficiente solução para a reciclagem desses resíduos. Mas outras parcelas existentes na composição do resíduo, como madeiras, plásticos e gesso de construção, merecem igual atenção para que se encontrem soluções mais adequadas que a deposição em aterros.

A simples geração de agregados de RCD reciclados não basta para solucionar os problemas causados por tal resíduo, sendo necessária a inserção econômica desses agregados em componentes que não se limitem aos necessários a uma administração pública, devendo atingir o mercado privado para que assim sejam absorvidos em sua maioria.

Como há uma variabilidade de materiais presentes na composição desse resíduo, como os de demolições por exemplo, atribui-se cada vez mais importância à identificação das origens e composições desses resíduos.

Não há dúvidas de que a reciclagem contribui de forma significativa para o desenvolvimento sustentável, mas também são indispensáveis políticas públicas eficientes que estimulem as ações voltadas para a sustentabilidade, sistemas de certificação ambiental, minimização de resíduos, aumento de durabilidade, projetos para aumento da vida útil.

As plantas de reciclagem devem ser mais complexas que a simples britagem de $\mathrm{RCD}$, devendo prever ações de reuso ou reciclagem para metais, placas de gesso acartonado e madeira. Cabe a cada país identificar e analisar criticamente seus RCD, pois há diferenças significativas entre eles.

${ }^{20}$ Entende-se como parcela orgânica do RCD os materiais constituídos a base de carbono. 
Quanto à inserção do resíduo no mercado, devem-se destacar os mecanismos de controle de qualidade, compreensão do ciclo de produto e a oferta inelástica dos resíduos.

A variabilidade dos agregados de RCD reciclados afeta as propriedades dos componentes reciclados, conforme foi demonstrado no capítulo 2. No Brasil, com a incipiente produção de agregados de RCD e limitada principalmente ao mercado de base de pavimentação, predomina a produção de agregados heterogêneos em composição e outras propriedades, além das prováveis contaminações causadas pela ausência de equipamentos de controle de qualidade.

A análise de amostras dos agregados graúdos de RCD reciclados da Central de Santo André revelou que sua composição apresenta variabilidade significativa, como também perceberam outros pesquisadores como ZORDAN (1997) e QUEBAUDBUYLE-BODIN (1999). Conseqüentemente, as outras caracterizações físicas dos agregados também apresentaram variabilidade, destacando-se os materiais pulverulentos e curvas granulométricas.

O estudo da variabilidade revelou-se importante, apesar das amostras analisadas não incluírem eventuais mudanças sazonais nem resíduos gerados na fase de construção, uma vez que a central de reciclagem estudada reciclava predominantemente resíduos provenientes de demolição.

Percebe-se que, no caso estudado, a geração de agregados miúdos é muito superior à dos agregados graúdos, fator que pode ser atribuída tanto a origem da matéria prima quanto a regulagem ou deficiências inerentes ao equipamento. Apesar de neste trabalho as caracterizações terem sido concentradas na parcela graúda, observa-se que a fração miúda merece ser estudada, pois representa maior contribuição na geração do total de agregados reciclados.

Quanto às técnicas de caracterização desses agregados graúdos, considera-se que o uso da absorção de água e massa especifica para se determinar as fases concreto e argamassa apresentou bons resultados, sendo uma evolução em relação à técnica anteriormente utilizada por ZORDAN (1997), pois oferece um método objetivo para identificar os teores de concreto e argamassa. Os experimentos de laboratório realizados demonstraram que os erros máximos ocorrem em torno de 10\%. Esta técnica poderá, futuramente ser utilizada em Centrais de Reciclagem para controle de qualidade. Esta conclusão é reforçada pela pequena (relativamente) variabilidade da massa específica e 
absorção das fases concreto/argamassa nas amostras de agregados graúdos de RCD reciclados da Central de Reciclagem de Santo André.

Os métodos convencionais de caracterização física, empregados para agregados naturais, podem e devem ser aplicados em centrais para controle de qualidade desses agregados. Controles de propriedades como granulometria, absorção e massa específica são simples e fornecem padrões de comportamento desta matéria-prima, constituindo bons detectores da heterogeneidade ou variabilidade.

Nas amostras realizadas, as contaminações por gesso, estiveram abaixo dos valores máximos especificados pela RILEM para utilização do agregado na produção concretos de cimento Portland. No entanto, dada as alterações tecnológicas que a construção civil vem sofrendo com a introdução de novas tecnologias como gesso acartonado, plásticos e outros materiais, recomenda-se agregar ao controle de qualidade, caracterizações químicas que visem ao controle de sulfatos ou outros contaminantes considerados relevantes.

A variação das curvas granulométricas é significativa, podendo prejudicar a produção de alguns componentes (blocos, por exemplo), quando empregada. O mesmo aplica-se para a propriedade índice de forma e massa específica, que influenciaria a massa dos blocos produzidos. A variabilidade da absorção influenciaria a produção de concreto e argamassas plásticos.

Os valores de massa específica e absorção de água da composição são influenciados pela porcentagem de rochas e concretos presentes na composição, tendo boa correlação em uma regressão linear empregada.

Constatou-se que a porcentagem no fundo do ensaio de granulometria tem correlação com o percentual de argamassa da composição.

O estudo da variabilidade das propriedades indicou a necessidade de adoção de procedimentos para homogeneização dos agregados de RCD pelas centrais de produção. Para o caso estudado, com produção relativamente baixa e resíduo oriundo de demolição, a formação das pilhas de homogeneização deve ser realizada em período superior a 2 dias. Destaca-se que em outras centrais, esse tempo de formação pode se alterar em função da origem dos RCD recebidos e da produção.

A análise de imagem complementada por ensaio de absorção e massa específica, como a aqui desenvolvida, pode vir a ser aplicada para o estudo da composição dos agregados graúdos de RCD reciclados. Seus princípios foram 
comprovados em experimentos de laboratório, quando os grãos são distribuídos de forma aleatória nos planos. Não se avaliou a possibilidade de se descontarem os erros médios para cada fase resultantes da orientação dos grãos nos planos, e considera-se esta uma hipótese a ser investigada no futuro.

No entanto, quando trabalha-se em condições que garantam a não orientação dos grãos (aleatoriedade) não é possivel identificar através da análise de imagem as dimensões características dos grãos, como comprimento, largura e espessura. Isto impede a caracterização da granulometria e cálculo automático do índice de forma desses agregados por análise de imagem, conforme trabalhos desenvolvidos por KWAN (1999) E MORA (1998).

Como continuidade da pesquisa sugere-se:

a) aprofundamento das técnicas de homogeneização para agregados graúdos de RCD reciclados;

b) aprimoramento do estudo da influência da composição nas características dos agregados empregando-se técnicas estatísticas como matrizes de correlação;

c) continuidade no desenvolvimento de um método de caracterização de agregados por análise de imagem, tentando obter conjuntamente outras propriedades, como granulometria e índice de forma, e obter a correlação área e massa sem a necessidade de determinação das massa específicas das fases.

d) desenvolvimento e aplicação de técnicas de caracterização de variabilidade para agregados miúdos de RCD reciclados. 
ANEXO 


\section{GRÁFICOS DE BOXES:}

A seguir, serão mostrados os gráficos de boxes dos dados empregados nas análises de resultados, indicando como os dados se apresentam:

Gráficos de boxes dos valores de absorção em função das fases da composição para as amostras horárias, obtidas dos resultados experimentais.

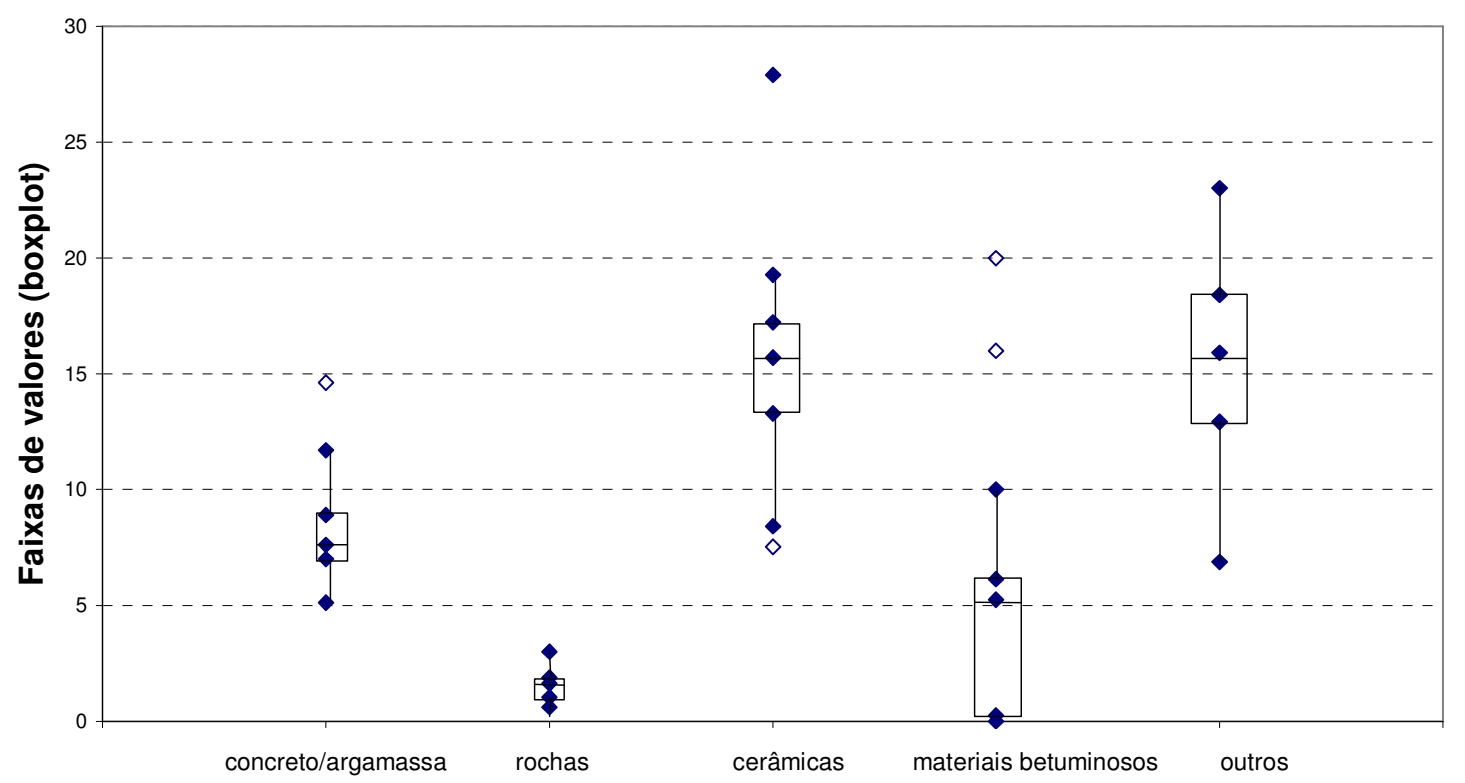

Fases da composição

Gráficos de boxes dos valores de massa específica em função das fases da composição para as amostras horárias, obtidas dos resultados experimentais:

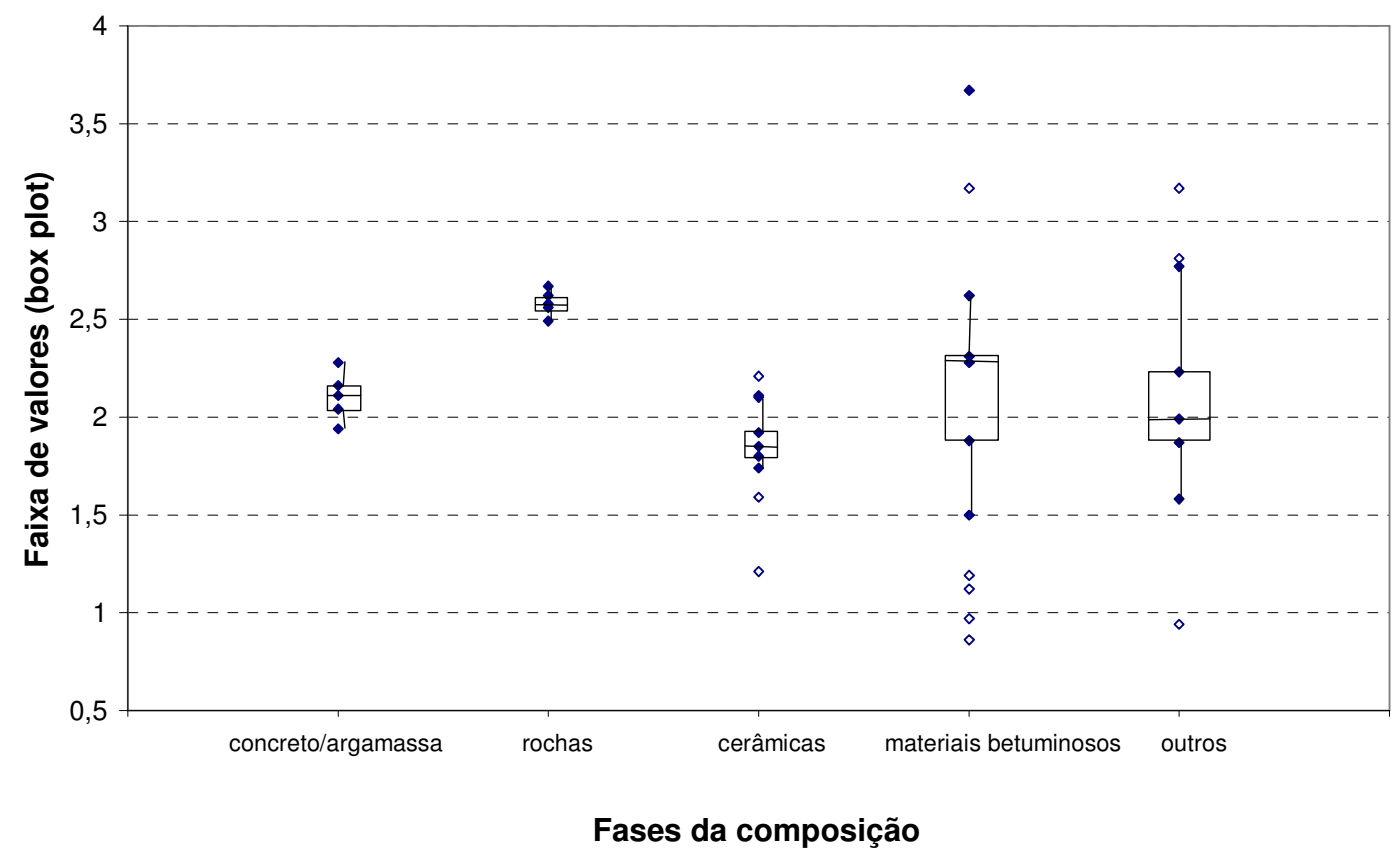


- Gráficos de boxes dos valores de índice de forma da composição para as amostras horárias, obtidas dos resultados experimentais:

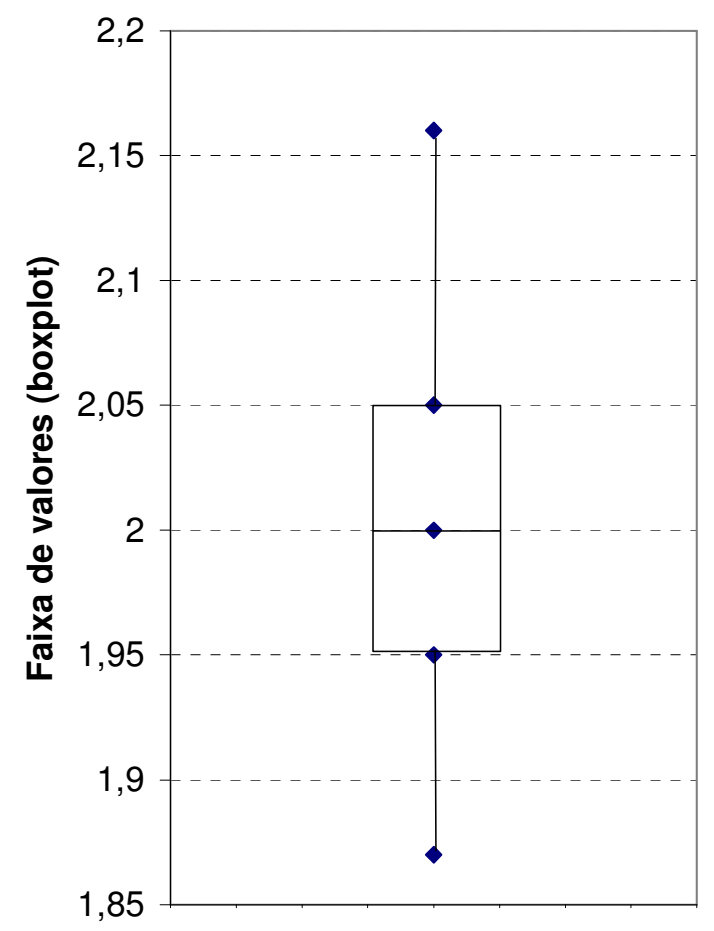

- Gráficos de boxes dos valores de teor de materiais pulverulentos da composição para as amostras horárias, obtidas dos resultados experimentais:

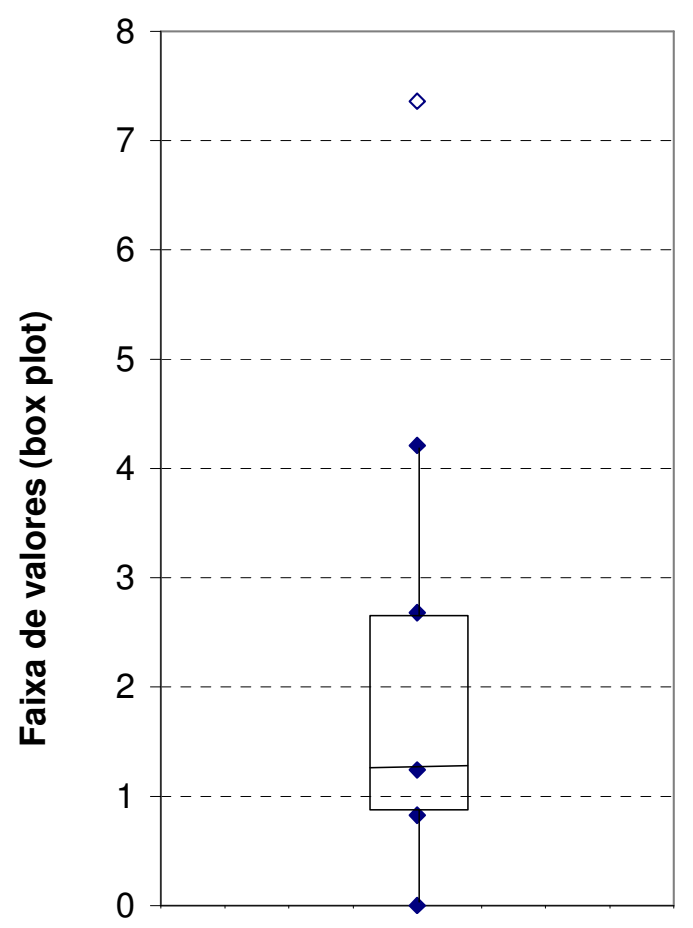


- Gráficos de boxes dos valores de presença em massa das fases na composição para as amostras horárias, obtidas dos resultados experimentais:

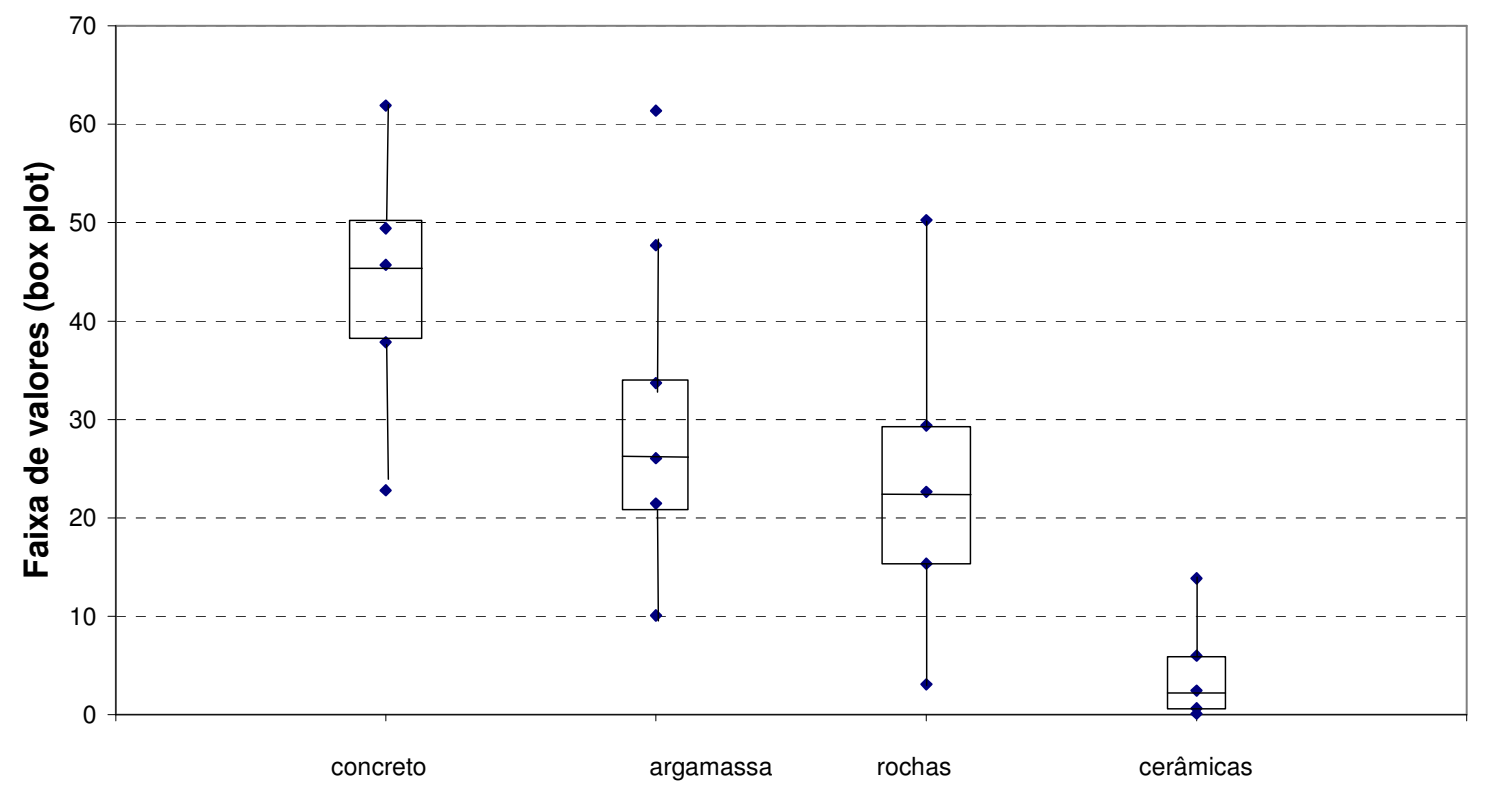

Fases da composição

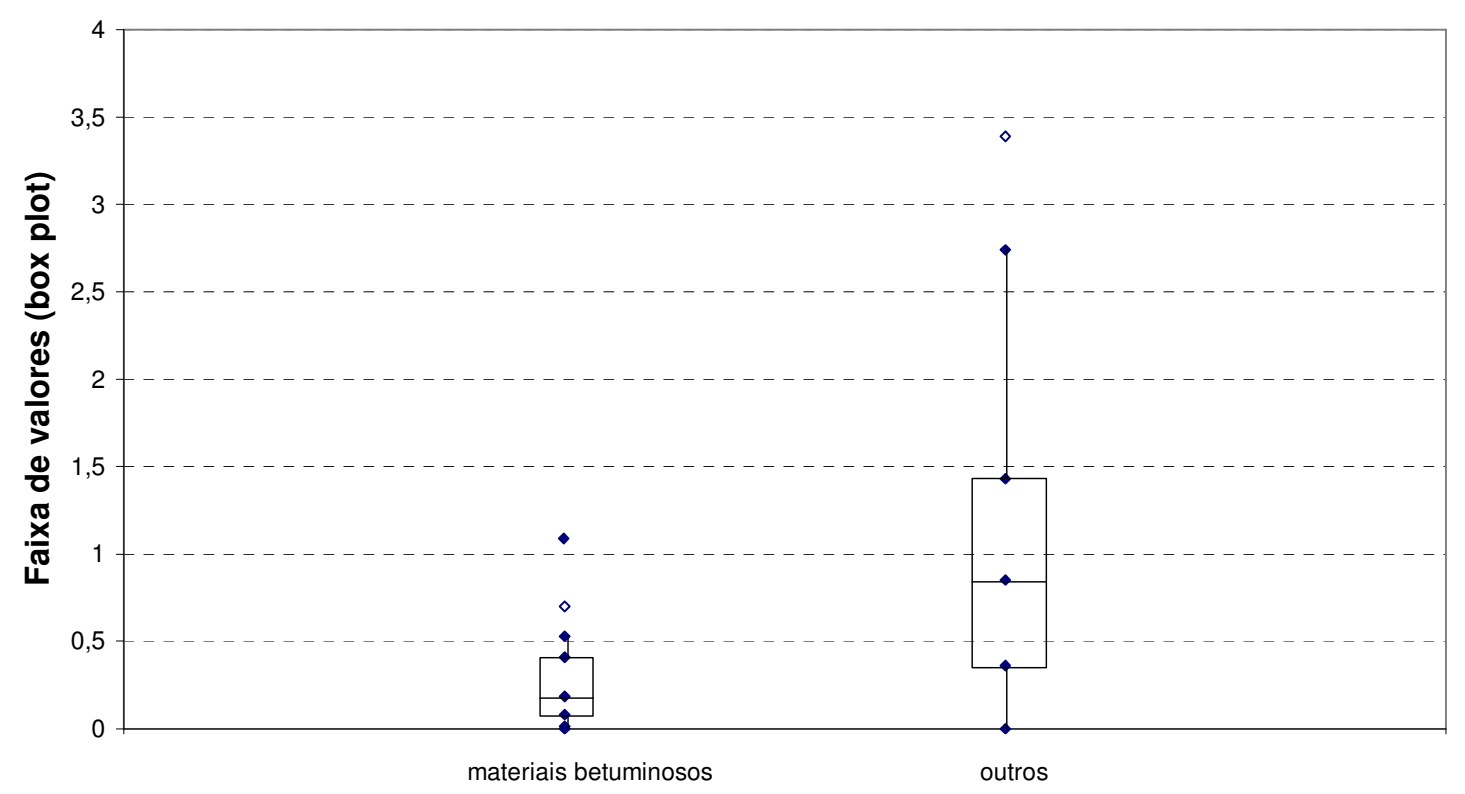

Fases da composição 
- Gráficos de boxes dos valores das percentagens passante nas peneiras dos ensaios de granulometrias para as amostras horárias, obtidas dos resultados experimentais:

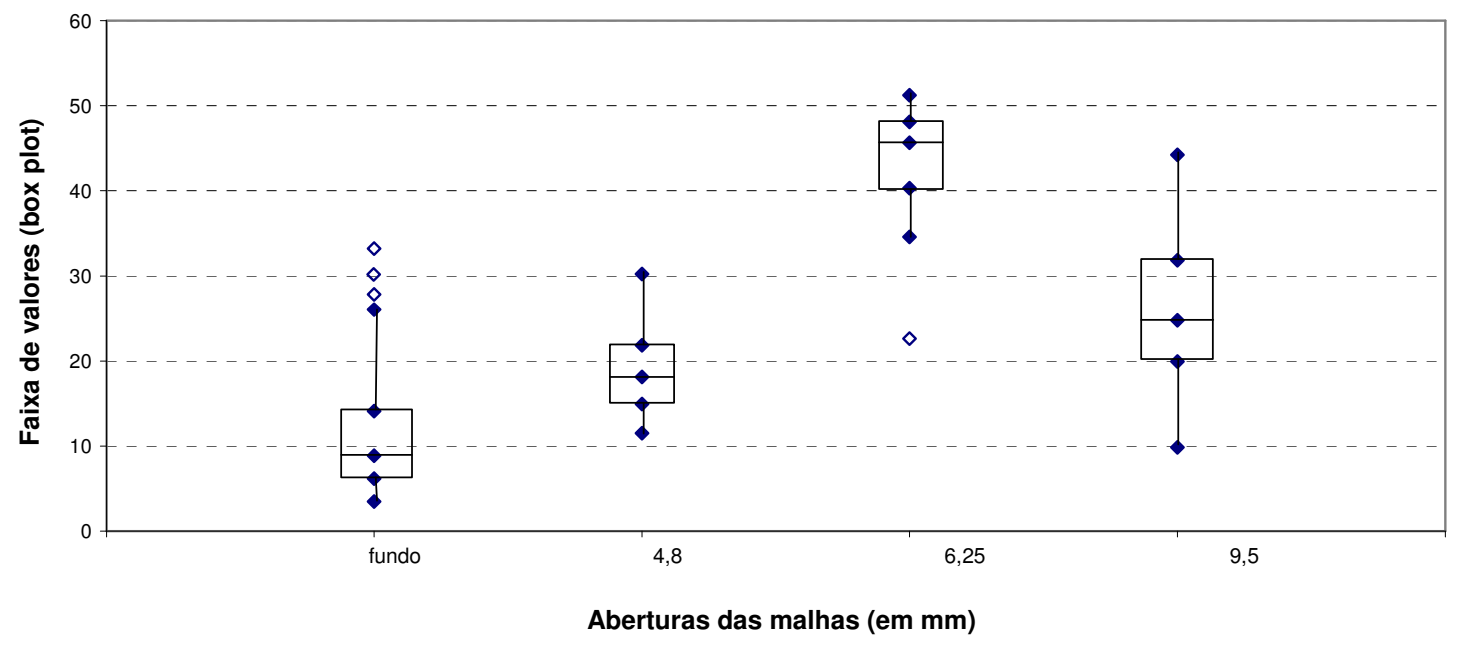




\section{HISTOGRAMAS E VERIFICAÇÕES DA NORMALIDADE :}

Em seguida serão apresentados os dados obtidos para as amostras experimentais do estudo.

- Histogramas e verificações de normalidade para a propriedade absorção em função das fases:

\section{Concreto/argamassa}

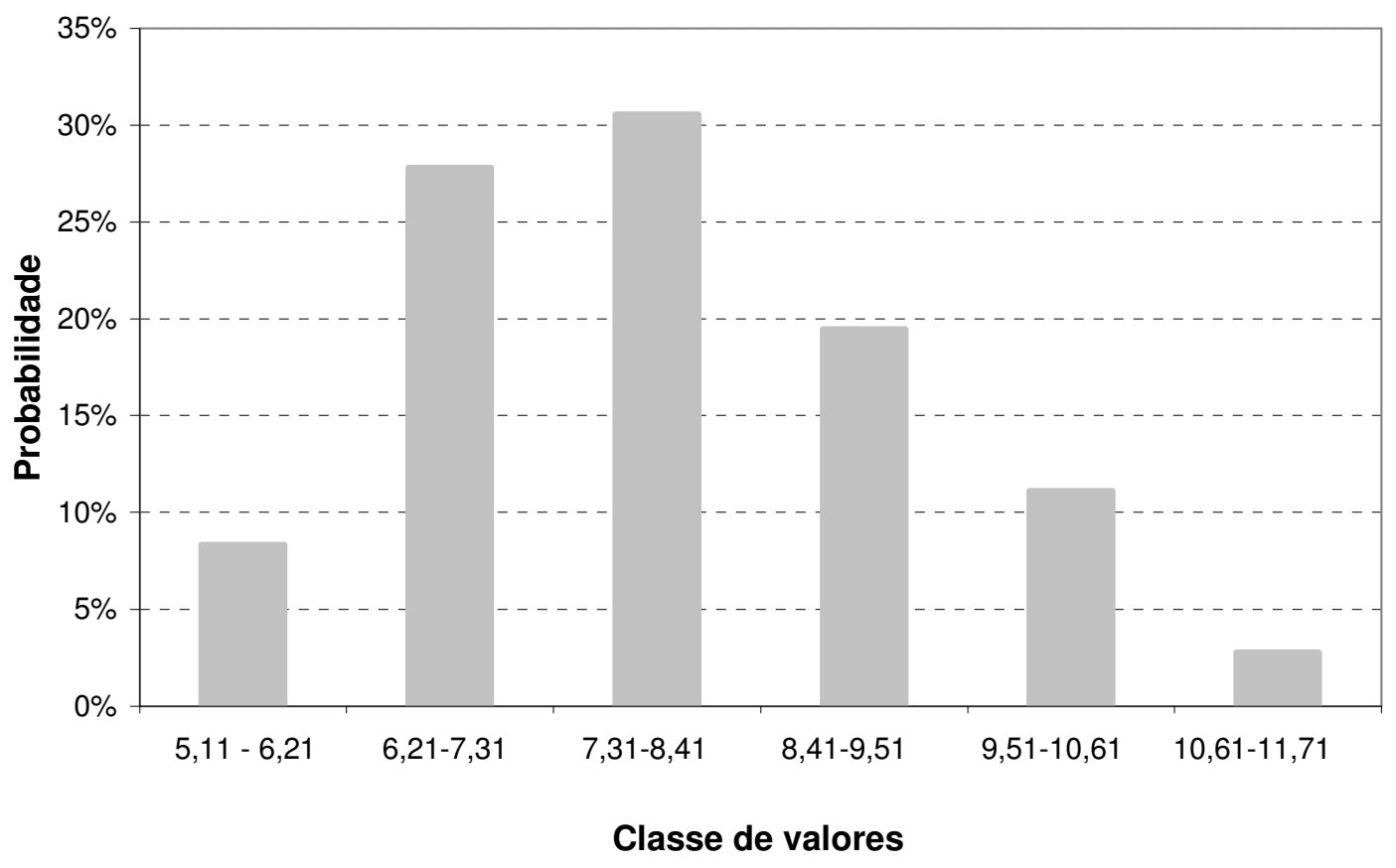

TESTE DE NORMALIDADE SHAPIRO-WILK concreto/argamassa

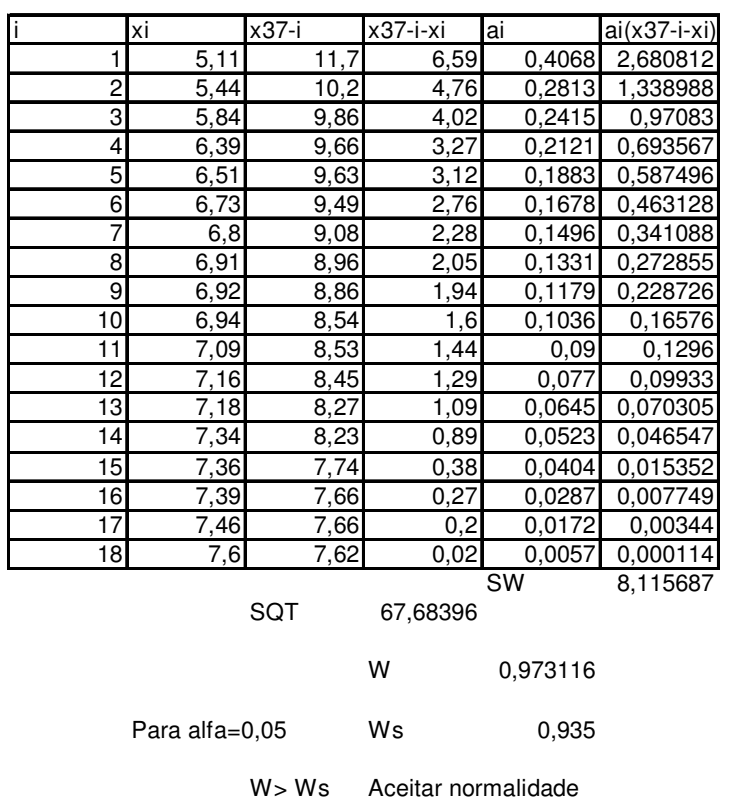


Rochas

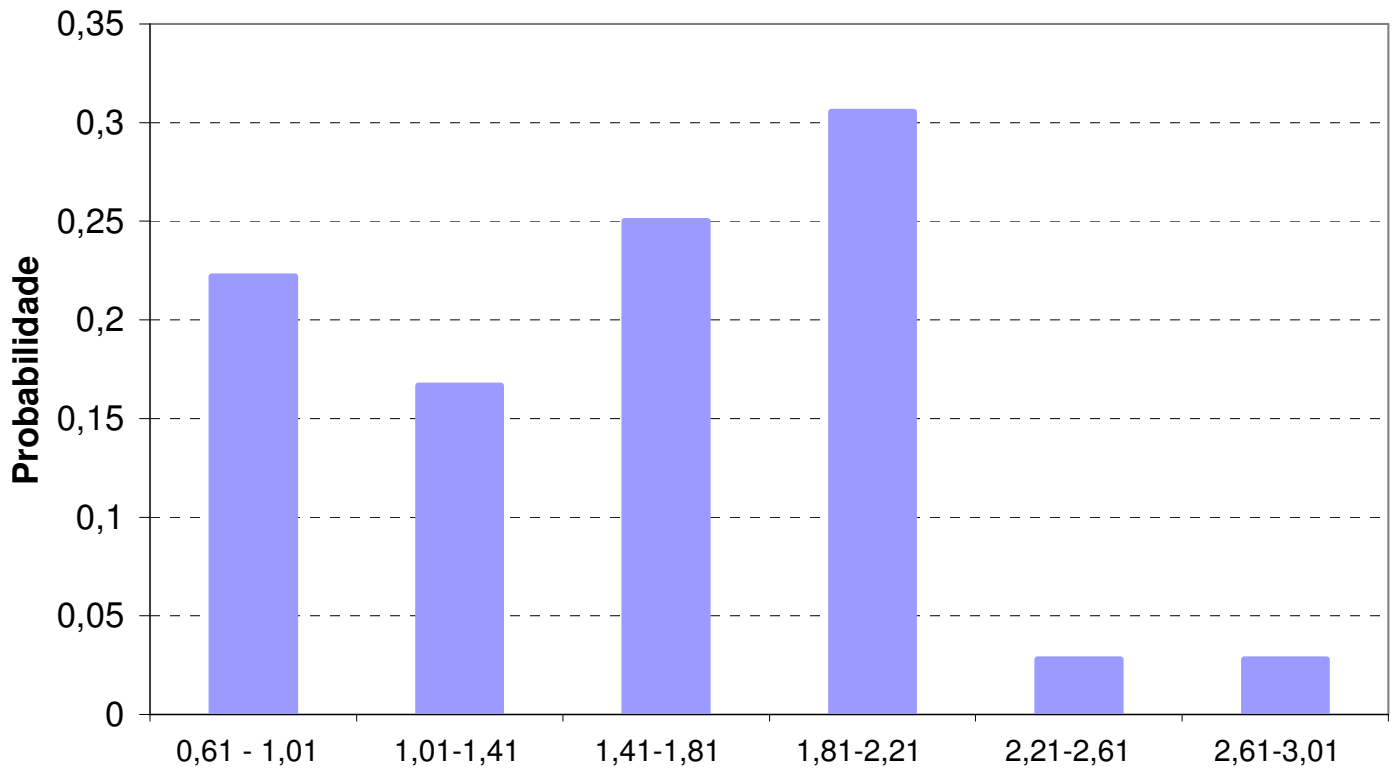

Classes de valores

TESTE DE NORMALIDADE SHAPIRO-WILK rochas

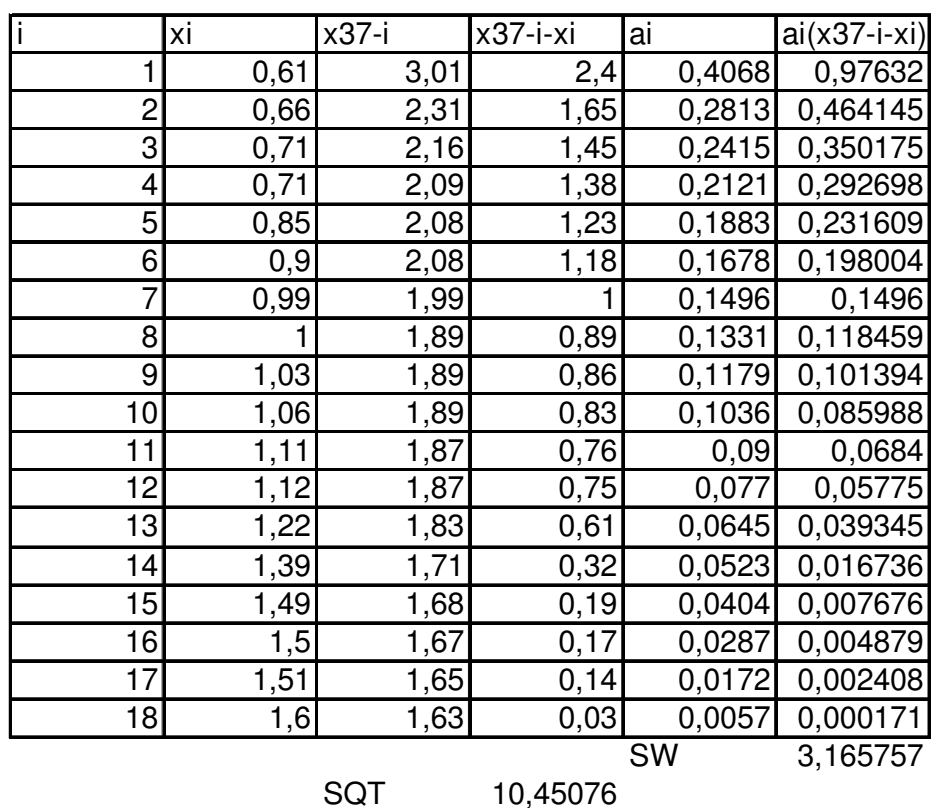

W $\quad 0,958975$

$\begin{array}{lll}\text { Para alfa }=0,05 \quad \text { Ws } & 0,935\end{array}$

W $>$ Ws Aceitar normalidade 


\section{Cerâmicas}

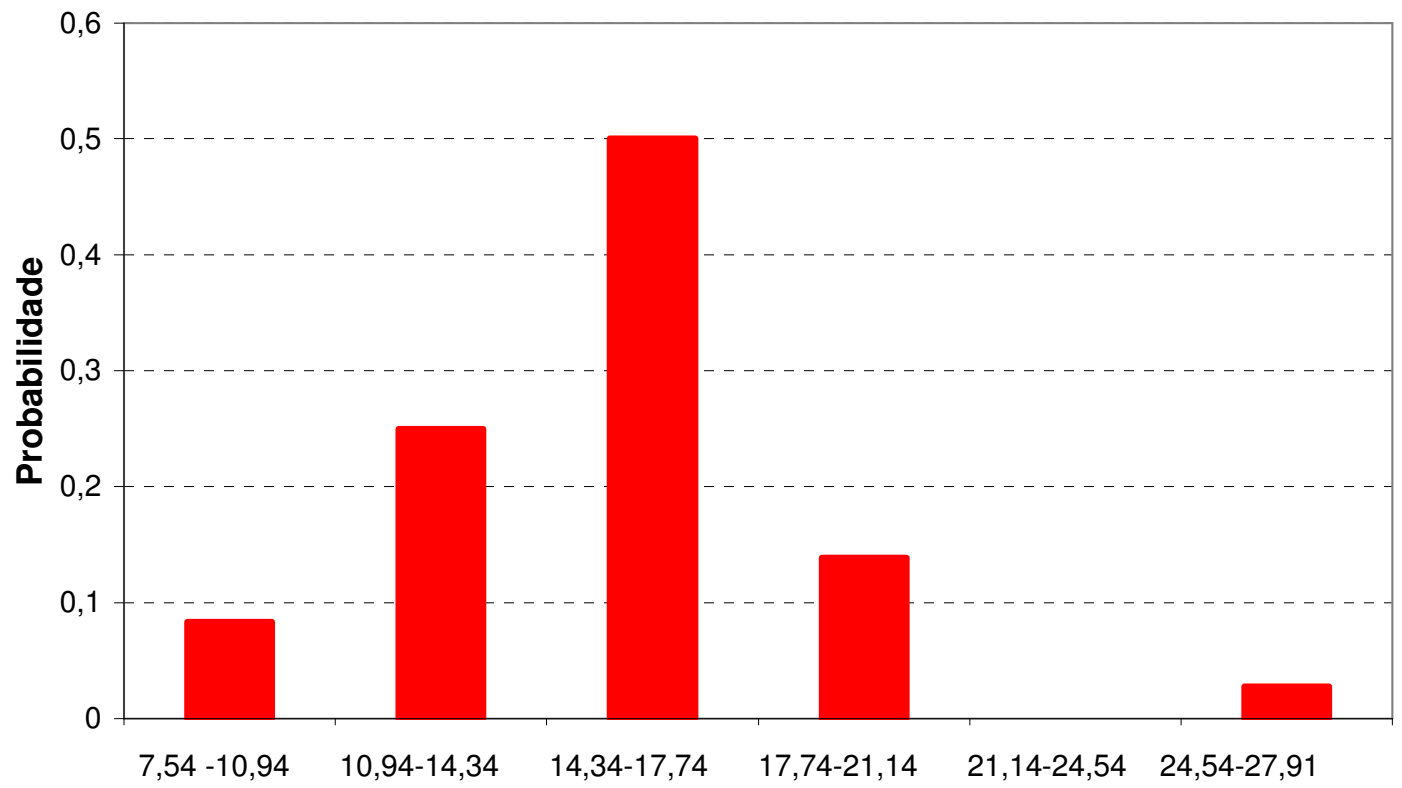

Classes de valores

TESTE DE NORMALIDADE SHAPIRO-WILK cerâmicas

\begin{tabular}{|r|r|r|r|r|r|}
\hline & $x i$ & $x 37-i$ & $x 37-i-x i$ & ai & ai(x37-i-xi) \\
\hline 1 & 7,54 & 27,91 & 20,37 & 0,4068 & 8,286516 \\
\hline 2 & 8,42 & 19,27 & 10,85 & 0,2813 & 3,052105 \\
\hline 3 & 10,84 & 18,58 & 7,74 & 0,2415 & 1,86921 \\
\hline 4 & 11,49 & 18,48 & 6,99 & 0,2121 & 1,482579 \\
\hline 5 & 11,86 & 17,82 & 5,96 & 0,1883 & 1,122268 \\
\hline 6 & 11,86 & 17,79 & 5,93 & 0,1678 & 0,995054 \\
\hline 7 & 12 & 17,67 & 5,67 & 0,1496 & 0,848232 \\
\hline 8 & 12,09 & 17,56 & 5,47 & 0,1331 & 0,728057 \\
\hline 9 & 12,87 & 17,46 & 4,59 & 0,1179 & 0,541161 \\
\hline 10 & 13,72 & 17,01 & 3,29 & 0,1036 & 0,340844 \\
\hline 11 & 13,75 & 16,88 & 3,13 & 0,09 & 0,2817 \\
\hline 12 & 14,28 & 16,85 & 2,57 & 0,077 & 0,19789 \\
\hline 13 & 14,7 & 16,84 & 2,14 & 0,0645 & 0,13803 \\
\hline 14 & 14,94 & 16,84 & 1,9 & 0,0523 & 0,09937 \\
\hline 15 & 14,97 & 16,51 & 1,54 & 0,0404 & 0,062216 \\
\hline 16 & 15 & 16,31 & 1,31 & 0,0287 & 0,037597 \\
\hline 17 & 15,45 & 15,97 & 0,52 & 0,0172 & 0,008944 \\
\hline 18 & 15,67 & 15,72 & 0,05 & 0,0057 & 0,000285 \\
\hline \multicolumn{7}{|c|}{ SW } & \multicolumn{5}{|c|}{20,09206} \\
\hline \multicolumn{7}{|c|}{ SQT } & 438,6484 &
\end{tabular}

W $\quad 0,920306$

$\begin{array}{lll}\text { Para alfa }=0,05 \quad \text { Ws } & 0,935\end{array}$

W $<$ Ws Valor próximo

Aceitar normalidade 
Materiais betuminosos

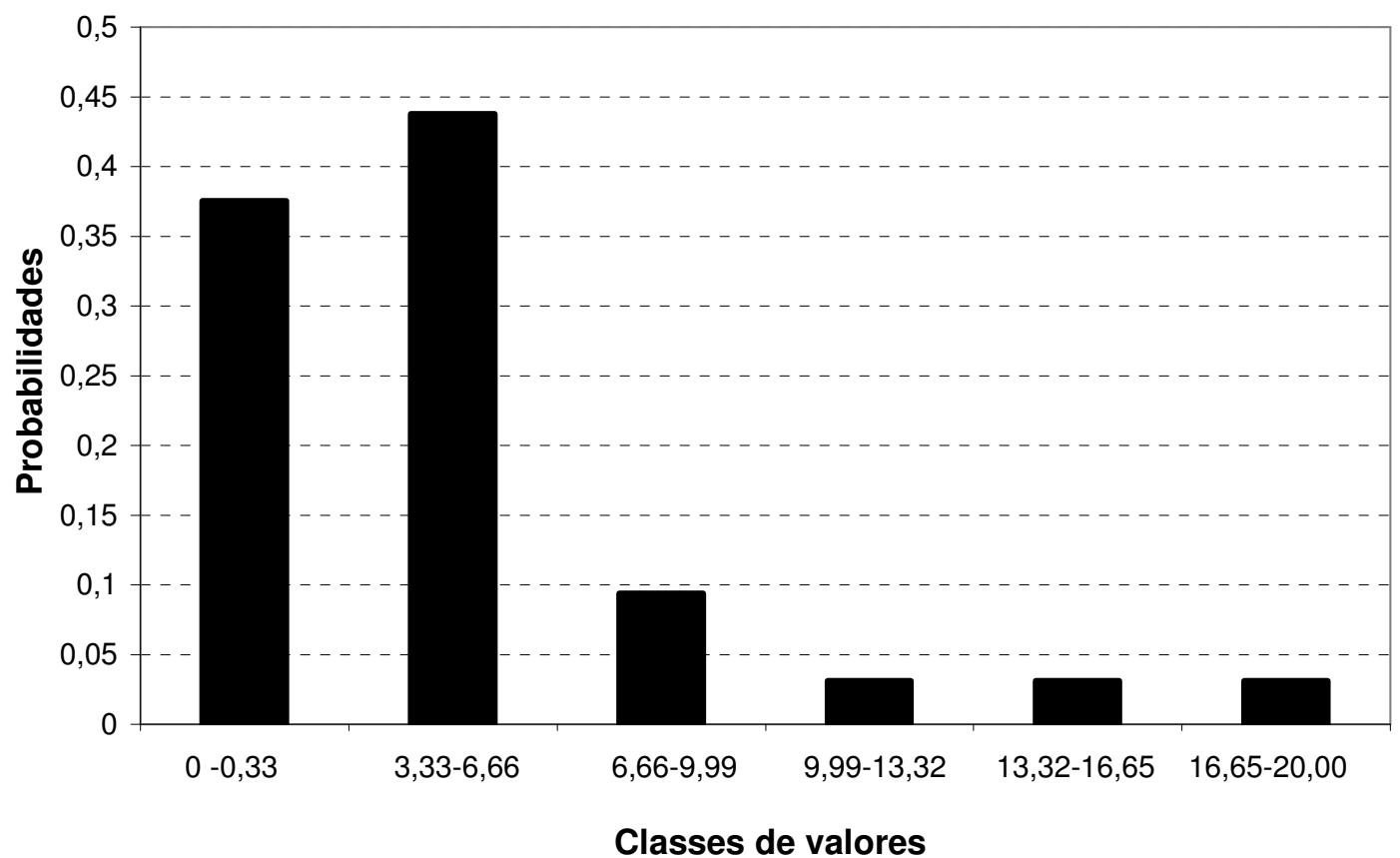

TESTE DE NORMALIDADE SHAPIRO-WILK betumes

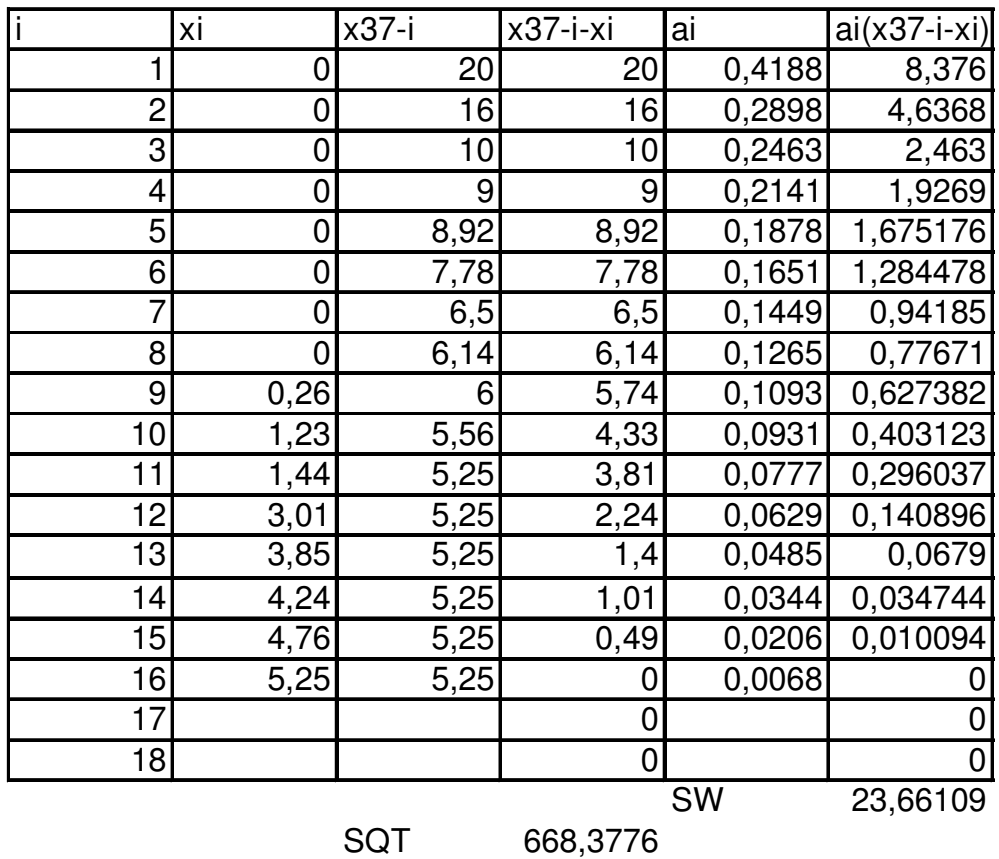

W $\quad 0,837621$

$\begin{array}{lll}\text { Para alfa }=0,05 \quad \text { Ws } & 0,93\end{array}$

W < Ws Não aceitar normalidade 
Outros

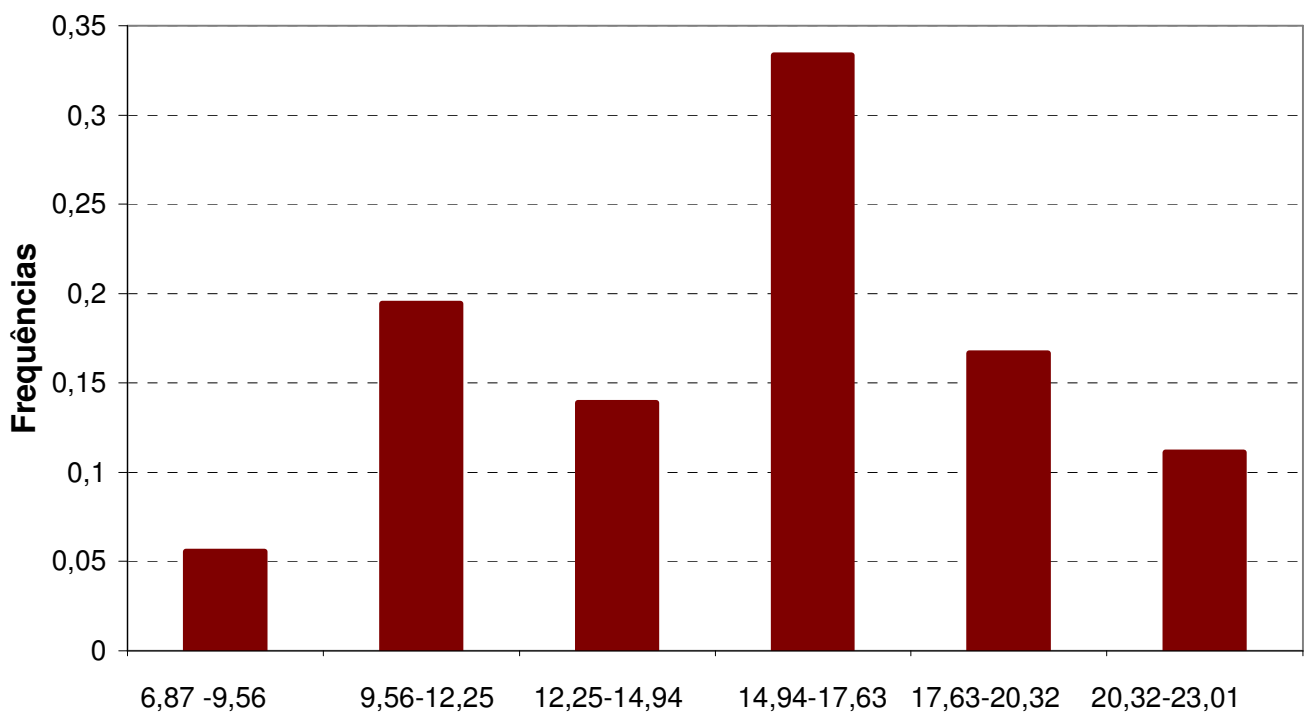

Classes de valores

TESTE DE NORMALIDADE SHAPIRO-WILK outros

\begin{tabular}{|r|r|r|r|r|r|}
\hline & xi & x37-i & x37-i-xi & ai & ai $(x 37-i-x i)$ \\
\hline 1 & 6,87 & 23,01 & 16,14 & 0,4068 & 6,565752 \\
\hline 2 & 8,63 & 22,45 & 13,82 & 0,2813 & 3,887566 \\
\hline 3 & 9,95 & 22,43 & 12,48 & 0,2415 & 3,01392 \\
\hline 4 & 10 & 20,33 & 10,33 & 0,2121 & 2,190993 \\
\hline 5 & 10,53 & 20,22 & 9,69 & 0,1883 & 1,824627 \\
\hline 6 & 10,81 & 19,85 & 9,04 & 0,1678 & 1,516912 \\
\hline 7 & 11,76 & 18,42 & 6,66 & 0,1496 & 0,996336 \\
\hline 8 & 11,76 & 18,42 & 6,66 & 0,1331 & 0,886446 \\
\hline 9 & 11,76 & 18,41 & 6,65 & 0,1179 & 0,784035 \\
\hline 10 & 12,46 & 18,41 & 5,95 & 0,1036 & 0,61642 \\
\hline 11 & 13,4 & 16,99 & 3,59 & 0,09 & 0,3231 \\
\hline 12 & 13,92 & 16,55 & 2,63 & 0,077 & 0,20251 \\
\hline 13 & 14,46 & 16,31 & 1,85 & 0,0645 & 0,119325 \\
\hline 14 & 14,75 & 16,28 & 1,53 & 0,0523 & 0,080019 \\
\hline 15 & 15,09 & 16,14 & 1,05 & 0,0404 & 0,04242 \\
\hline 16 & 15,21 & 16 & 0,79 & 0,0287 & 0,022673 \\
\hline 17 & 15,38 & 15,92 & 0,54 & 0,0172 & 0,009288 \\
\hline 18 & 15,88 & 15,91 & 0,03 & 0,0057 & 0,000171 \\
\hline \multicolumn{7}{|c|}{ SW } & 23,08251 \\
\hline
\end{tabular}

SQT $\quad 546,1187$

W $\quad 0,975617$

$\begin{array}{lll}\text { Para alfa }=0,05 \quad \text { Ws } & 0,93\end{array}$

W $>$ Ws Aceitar normalidade 
- Histogramas e verificações de normalidade para a propriedade materiais pulverulentos:

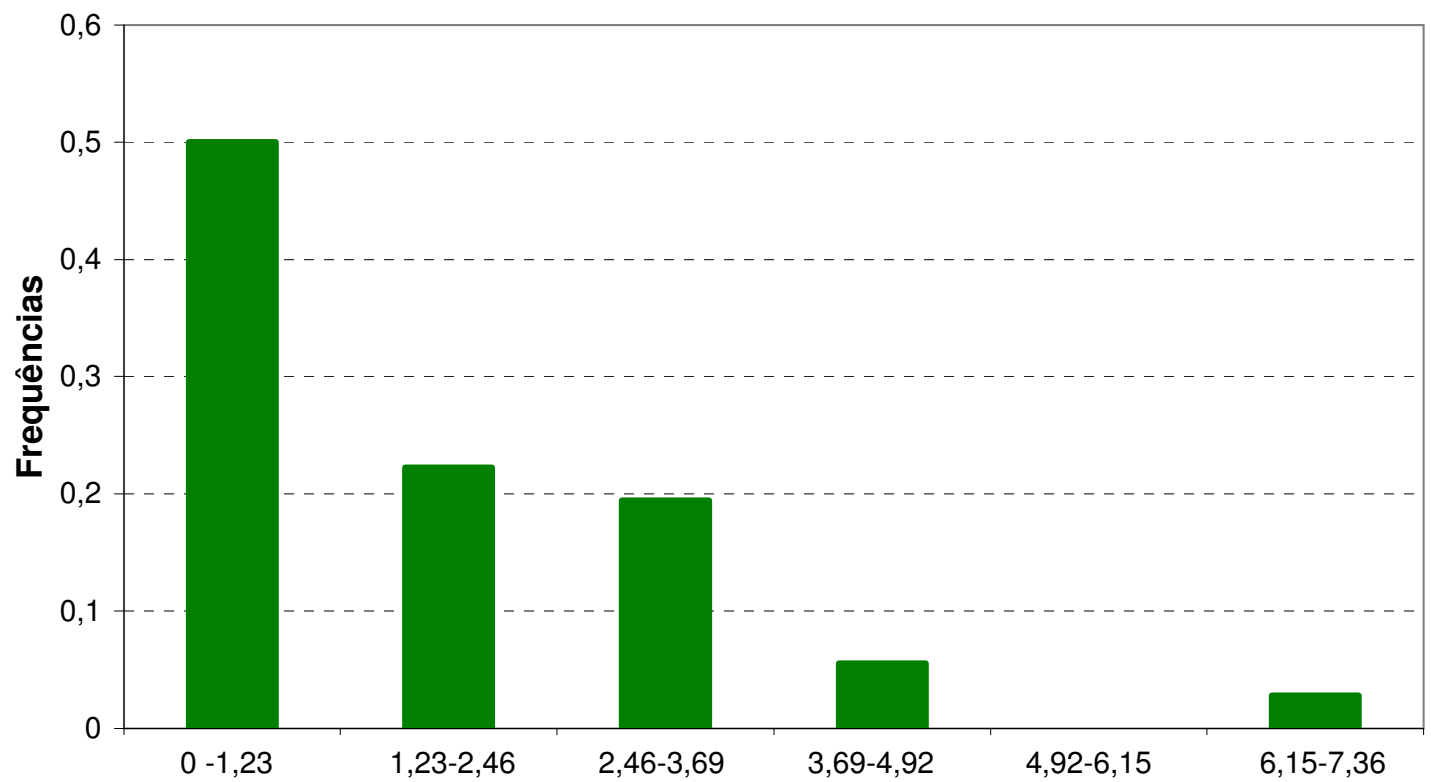

Classes de valores

TESTE DE NORMALIDADE SHAPIRO-WILK materiais pulverulentos

\begin{tabular}{|r|r|r|r|r|r|}
\hline & xi & x37-i & x37-i-xi & ai & ai (x37-i-xi) \\
\hline 1 & 0,00 & 7,36 & 7,356322 & 0,4068 & 2,992552 \\
\hline 2 & 0,00 & 4,21 & 4,21286 & 0,2813 & 1,185078 \\
\hline 3 & 0,04 & 3,95 & 3,913166 & 0,2415 & 0,94503 \\
\hline 4 & 0,14 & 3,53 & 3,389545 & 0,2121 & 0,718922 \\
\hline 5 & 0,20 & 3,02 & 2,823655 & 0,1883 & 0,531694 \\
\hline 6 & 0,32 & 2,84 & 2,519779 & 0,1678 & 0,422819 \\
\hline 7 & 0,37 & 2,70 & 2,337245 & 0,1496 & 0,349652 \\
\hline 8 & 0,76 & 2,70 & 1,938511 & 0,1331 & 0,25016 \\
\hline 9 & 0,80 & 2,69 & 1,896383 & 0,1179 & 0,223584 \\
\hline 10 & 0,85 & 2,67 & 1,81454 & 0,1036 & 0,187986 \\
\hline 11 & 0,86 & 2,27 & 1,402709 & 0,09 & 0,126244 \\
\hline 12 & 0,98 & 2,11 & 1,124001 & 0,077 & 0,086548 \\
\hline 13 & 1,00 & 1,66 & 0,66277 & 0,0645 & 0,042749 \\
\hline 14 & 1,02 & 1,64 & 0,620147 & 0,0523 & 0,022434 \\
\hline 15 & 1,06 & 1,63 & 0,573352 & 0,0404 & 0,023163 \\
\hline 16 & 1,11 & 1,43 & 0,318883 & 0,0287 & 0,009152 \\
\hline 17 & 1,16 & 1,40 & 0,239514 & 0,0172 & 0,00412 \\
\hline 18 & 1,22 & 1,26 & 0,041367 & 0,0057 & 0,000236 \\
\hline \multicolumn{5}{|c|}{ SW } & 8,139977 \\
\hline \multicolumn{5}{|c|}{ SQT } & 77,32442 \\
\hline
\end{tabular}

W $\quad 0,856899$

$\begin{array}{lll}\text { Para alfa }=0,05 \quad \text { Ws } & 0,935\end{array}$

W $<$ Ws Não aceitar a normalidade 
- Histogramas e verificações de normalidade para a propriedade massa específica em função das fases da composição:

\section{Concreto/argamassa}

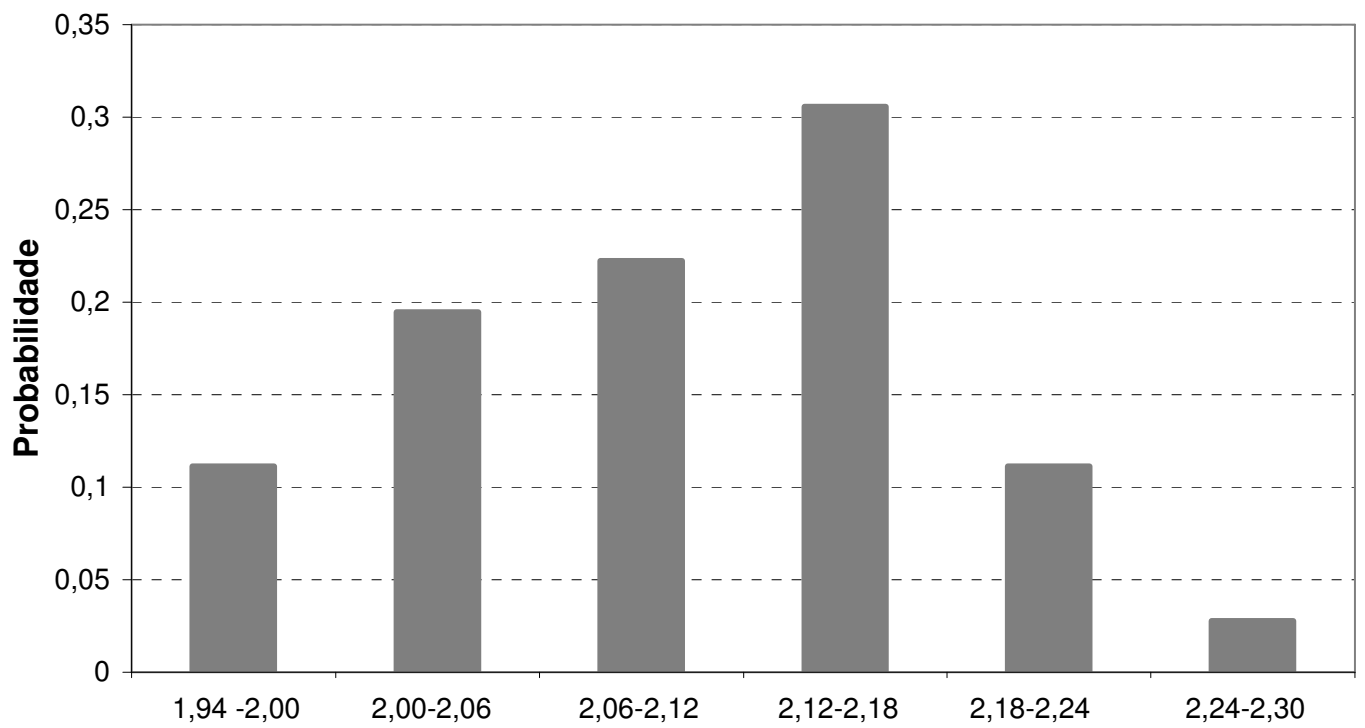

Classes de valores

TESTE DE NORMALIDADE SHAPIRO-WILK concreto/argamassa

\begin{tabular}{|r|r|r|r|r|r|}
\hline$i$ & xi & x37-i & \multicolumn{1}{|c|}{$\times 37-i-x i$} & ai & ai(x37-i-xi) \\
\hline 1 & 1,94 & 2,28 & 0,341333 & 0,4068 & 0,138854 \\
\hline 2 & 1,96 & 2,25 & 0,293353 & 0,2813 & 0,08252 \\
\hline 3 & 1,96 & 2,20 & 0,242842 & 0,2415 & 0,058646 \\
\hline 4 & 1,98 & 2,19 & 0,209641 & 0,2121 & 0,044465 \\
\hline 5 & 2,01 & 2,19 & 0,180803 & 0,1883 & 0,034045 \\
\hline 6 & 2,02 & 2,18 & 0,161155 & 0,1678 & 0,027042 \\
\hline 7 & 2,03 & 2,17 & 0,142 & 0,1496 & 0,021243 \\
\hline 8 & 2,04 & 2,17 & 0,133115 & 0,1331 & 0,017718 \\
\hline 9 & 2,04 & 2,16 & 0,118778 & 0,1179 & 0,014004 \\
\hline 10 & 2,05 & 2,16 & 0,109809 & 0,1036 & 0,011376 \\
\hline 11 & 2,06 & 2,15 & 0,093729 & 0,09 & 0,008436 \\
\hline 12 & 2,06 & 2,15 & 0,090559 & 0,077 & 0,006973 \\
\hline 13 & 2,07 & 2,15 & 0,08106 & 0,0645 & 0,005228 \\
\hline 14 & 2,07 & 2,14 & 0,071227 & 0,0523 & 0,003725 \\
\hline 15 & 2,10 & 2,14 & 0,04 & 0,0404 & 0,001616 \\
\hline 16 & 2,10 & 2,13 & 0,031315 & 0,0287 & 0,000899 \\
\hline 17 & 2,11 & 2,13 & 0,017362 & 0,0172 & 0,000299 \\
\hline 18 & 2,11 & 2,11 & 0,001111 & 0,0057 & $6,33 \mathrm{E}-06$ \\
\hline \multicolumn{5}{|c|}{ SW } & 0,477095
\end{tabular}

SQT $\quad 0,233255$

W

0,975842

Para alfa $=0,05$

Ws

0,935

W $>$ Ws Aceitar normalidade 
Rochas

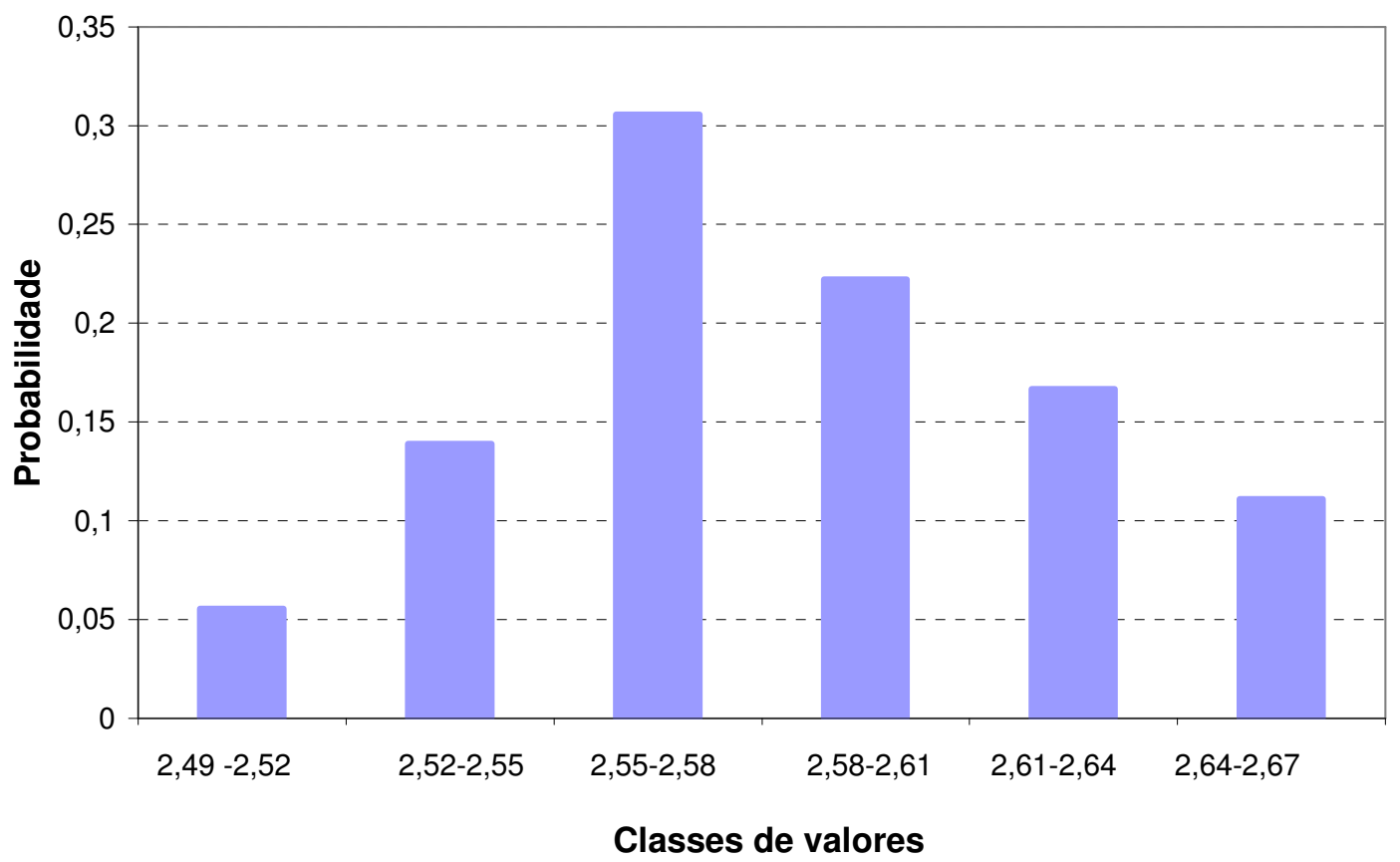

TESTE DE NORMALIDADE SHAPIRO-WILK rochas

\begin{tabular}{|c|c|c|c|c|c|}
\hline & $\mathrm{xi}$ & $\times 37-i$ & x37-i-xi & ai & ai (x37-i-xi) \\
\hline 1 & 2,49 & 2,67 & 0,173498 & 0,4068 & 0,070579 \\
\hline 2 & 2,51 & 2,66 & 0,148595 & 0,2813 & 0,0418 \\
\hline 3 & 2,52 & 2,65 & 0,129214 & 0,2415 & 0,031205 \\
\hline 4 & 2,54 & 2,65 & 0,109757 & 0,2121 & 0,023279 \\
\hline 5 & 2,55 & 2,63 & 0,083136 & 0,1883 & 0,015655 \\
\hline 6 & 2,55 & 2,63 & 0,081579 & 0,1678 & 0,013689 \\
\hline 7 & 2,55 & 2,63 & 0,08 & 0,1496 & 0,011968 \\
\hline 8 & 2,56 & 2,63 & 0,07 & 0,1331 & 0,009317 \\
\hline 9 & 2,56 & 2,63 & 0,067907 & 0,1179 & 0,008006 \\
\hline 10 & 2,56 & 2,61 & 0,051323 & 0,1036 & 0,005317 \\
\hline 11 & 2,56 & 2,61 & 0,045839 & 0,09 & 0,004125 \\
\hline 12 & 2,57 & 2,60 & 0,033095 & 0,077 & 0,002548 \\
\hline 13 & 2,57 & 2,59 & 0,023818 & 0,0645 & 0,001536 \\
\hline 14 & 2,57 & 2,59 & 0,020979 & 0,0523 & 0,001097 \\
\hline 15 & 2,57 & 2,59 & 0,016829 & 0,0404 & 0,00068 \\
\hline 16 & 2,58 & 2,59 & 0,011204 & 0,0287 & 0,000322 \\
\hline 17 & 2,58 & 2,59 & 0,005844 & 0,0172 & 0,000101 \\
\hline 18 & 2,58 & 2,58 & 0,003494 & 0,0057 & $1,99 \mathrm{E}-05$ \\
\hline & & & & & 0,241245 \\
\hline
\end{tabular}

W $\quad 0,974367$

Para alfa $=0,05 \quad$ Ws $\quad 0,935$

W $>$ Ws Aceitar normalidade 


\section{Cerâmicas}

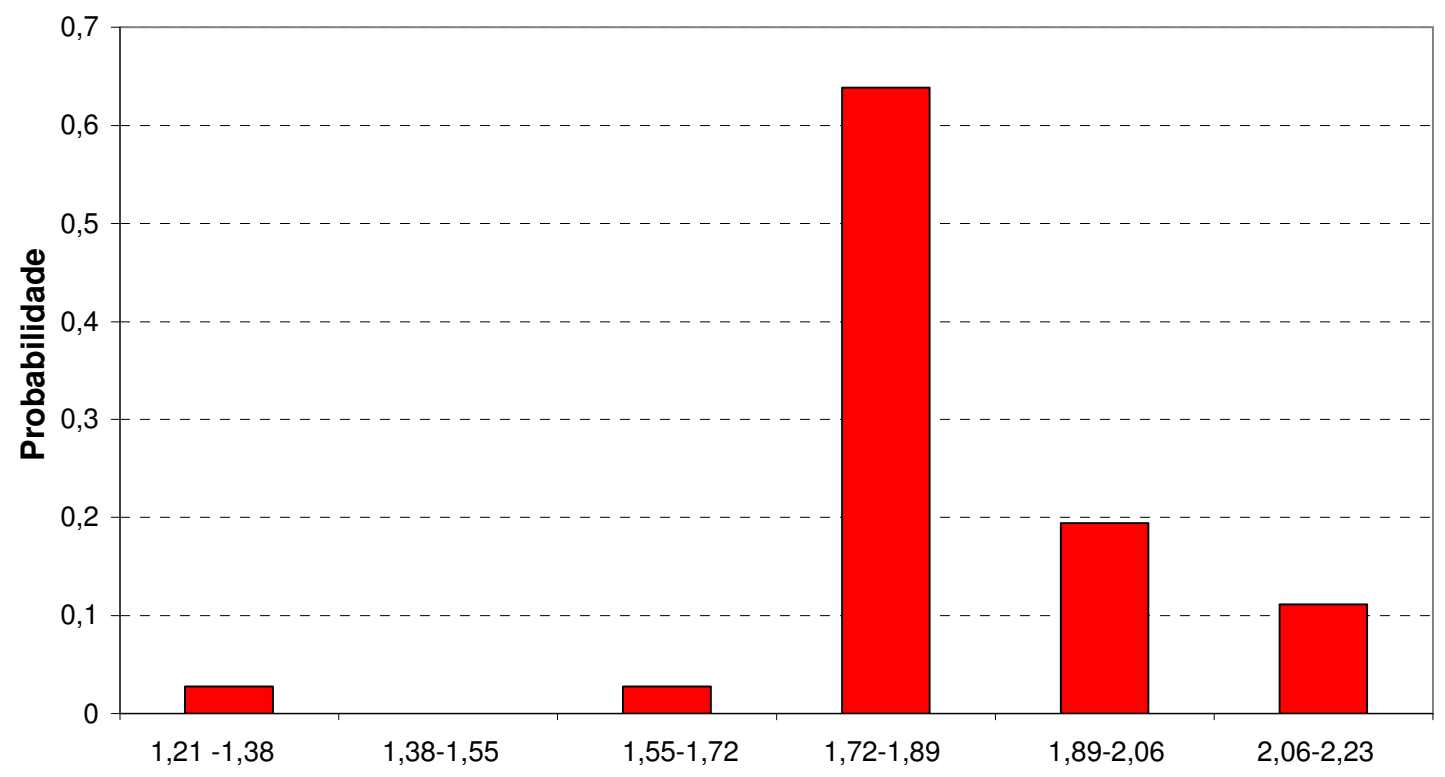

Classes de valores

TESTE DE NORMALIDADE SHAPIRO-WILK cerâmicas

\begin{tabular}{|r|r|r|r|r|r|}
\hline$i$ & xi & x37-i & x37-i-xi & ai & ai(x37-i-xi) \\
\hline 1 & 1,21 & 2,21 & 0,998708 & 0,4068 & 0,406274 \\
\hline 2 & 1,59 & 2,11 & 0,521991 & 0,2813 & 0,146836 \\
\hline 3 & 1,74 & 2,10 & 0,357364 & 0,2415 & 0,086303 \\
\hline 4 & 1,76 & 2,08 & 0,320402 & 0,2121 & 0,067957 \\
\hline 5 & 1,77 & 1,98 & 0,211344 & 0,1883 & 0,039796 \\
\hline 6 & 1,77 & 1,97 & 0,198261 & 0,1678 & 0,033268 \\
\hline 7 & 1,77 & 1,97 & 0,195352 & 0,1496 & 0,029225 \\
\hline 8 & 1,80 & 1,97 & 0,171375 & 0,1331 & 0,02281 \\
\hline 9 & 1,80 & 1,93 & 0,138095 & 0,1179 & 0,016281 \\
\hline 10 & 1,80 & 1,91 & 0,110508 & 0,1036 & 0,011449 \\
\hline 11 & 1,80 & 1,91 & 0,107895 & 0,09 & 0,009711 \\
\hline 12 & 1,83 & 1,89 & 0,06 & 0,077 & 0,00462 \\
\hline 13 & 1,84 & 1,89 & 0,053636 & 0,0645 & 0,00346 \\
\hline 14 & 1,84 & 1,89 & 0,0506 & 0,0523 & 0,002646 \\
\hline 15 & 1,84 & 1,88 & 0,036877 & 0,0404 & 0,00149 \\
\hline 16 & 1,84 & 1,87 & 0,03 & 0,0287 & 0,000861 \\
\hline 17 & 1,85 & 1,86 & 0,01 & 0,0172 & 0,000172 \\
\hline 18 & 1,85 & 1,85 & 0,002962 & 0,0057 & $1,69 \mathrm{E}-05$ \\
\hline \multicolumn{7}{|c|}{ SW } & \multicolumn{3}{|c}{0,883176}
\end{tabular}

SQT

0,916736

W $\quad 0,850845$

Para alfa $=0,05$

Ws

0,935

\section{W $<$ Ws Não aceitar normalidade}


Materiais betuminosos

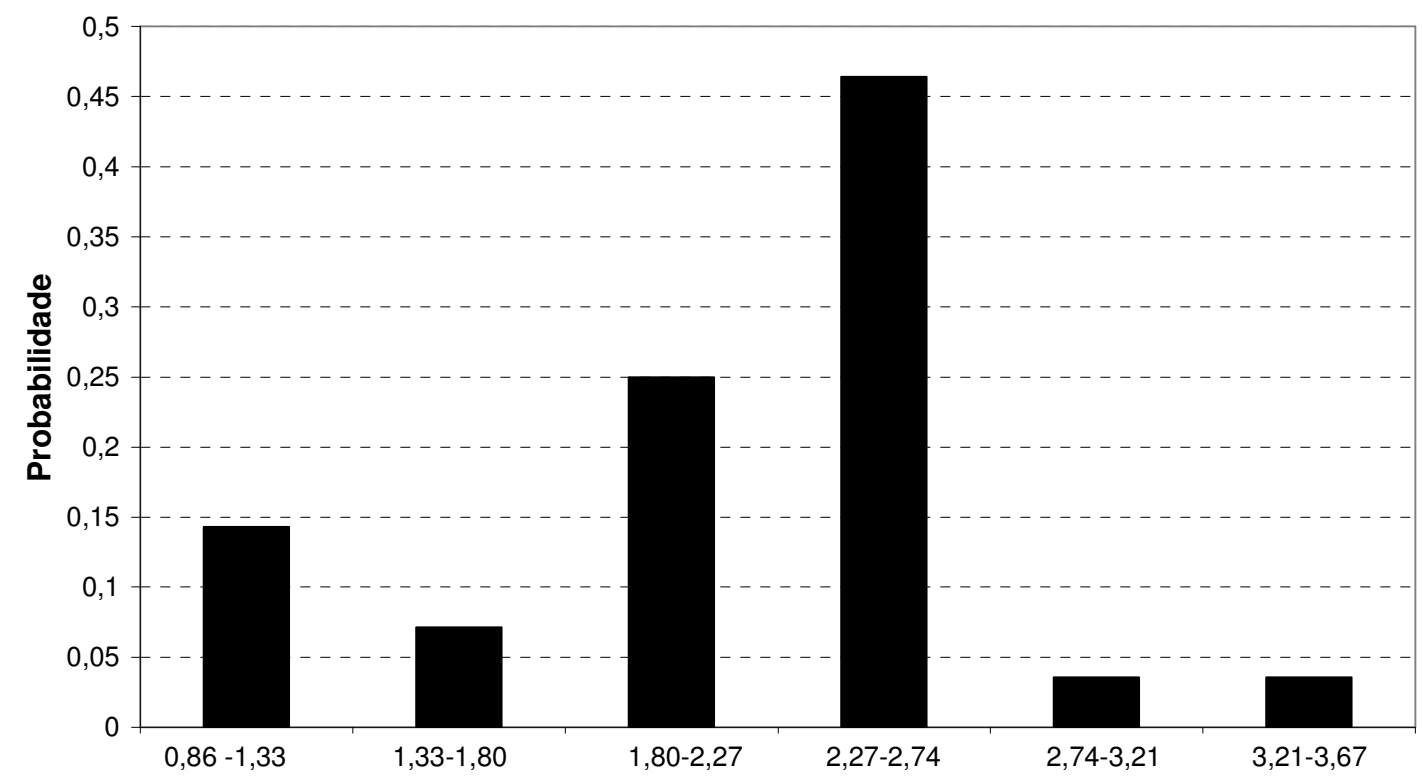

Classes de valores

TESTE DE NORMALIDADE SHAPIRO-WILK materiais betuminosos

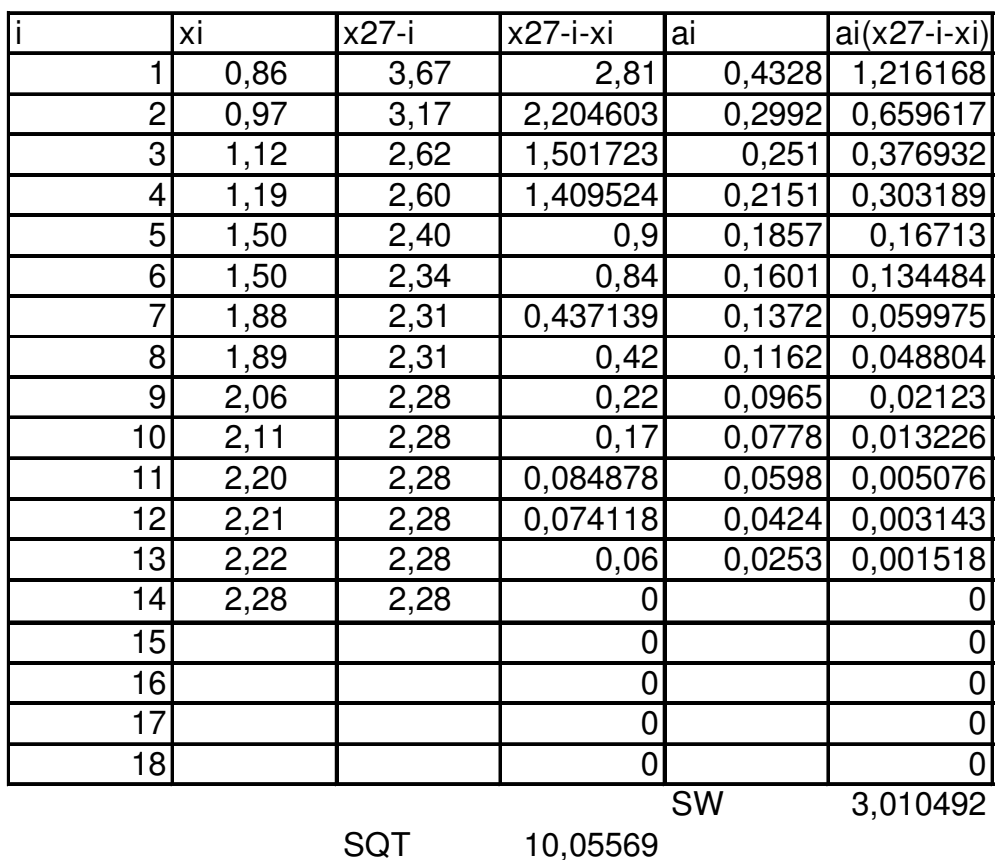

W $\quad 0,901287$

$\begin{array}{lll}\text { Para alfa }=0,05 \quad \text { Ws } & 0,924\end{array}$

$\mathrm{W}<\mathrm{Ws}$ Muito próximo

Aceitar normalidade 
Outros

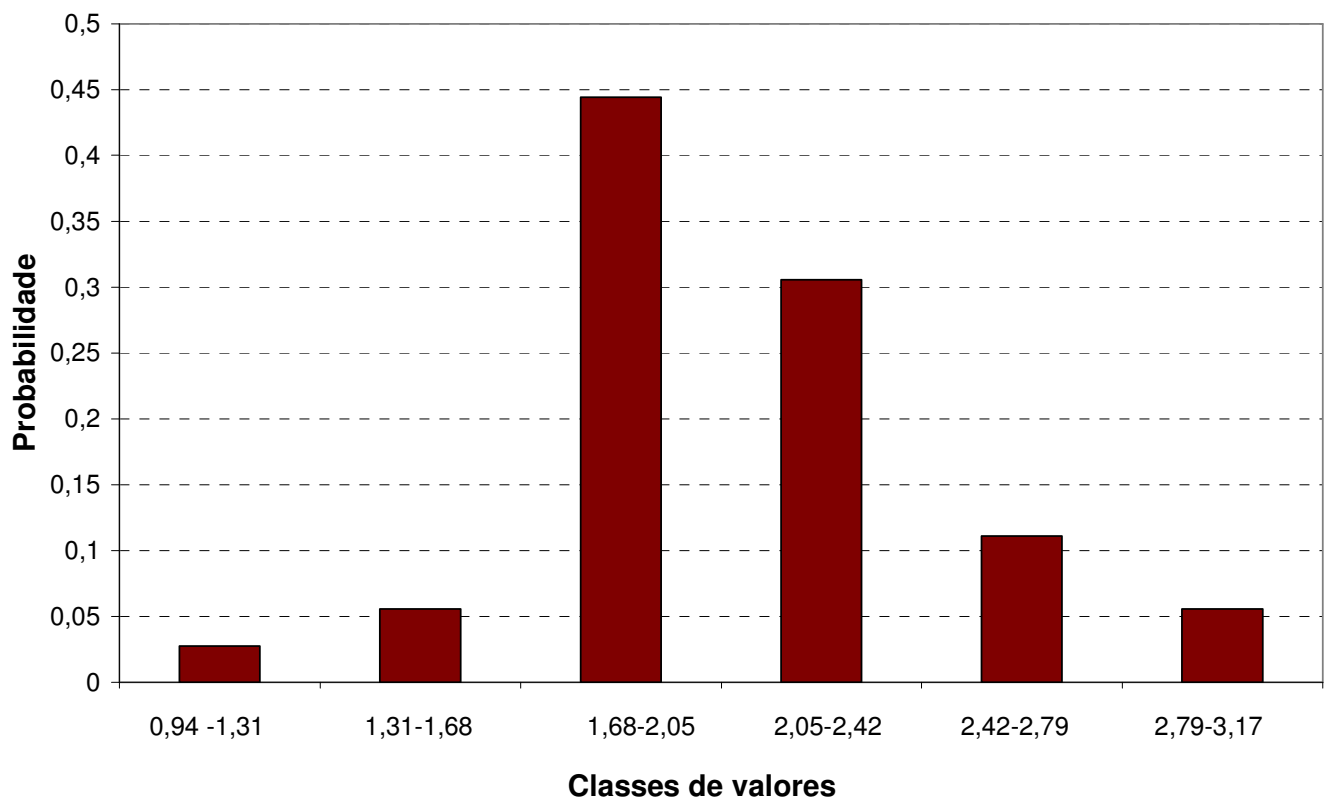

TESTE DE NORMALIDADE SHAPIRO-WILK outros

\begin{tabular}{|r|r|r|r|r|r|}
\hline i & xi & \multicolumn{1}{l|}{ x37-i } & x37-i-xi & ai & ai $(x 37-i-x i)$ \\
\hline 1 & 0,94 & 3,17 & 2,229561 & 0,4068 & 0,906985 \\
\hline 2 & 1,58 & 2,81 & 1,229355 & 0,2813 & 0,345818 \\
\hline 3 & 1,68 & 2,77 & 1,092329 & 0,2415 & 0,263797 \\
\hline 4 & 1,72 & 2,73 & 1,012145 & 0,2121 & 0,214676 \\
\hline 5 & 1,75 & 2,60 & 0,85 & 0,1883 & 0,160055 \\
\hline 6 & 1,75 & 2,51 & 0,759275 & 0,1678 & 0,127406 \\
\hline 7 & 1,78 & 2,38 & 0,597014 & 0,1496 & 0,089313 \\
\hline 8 & 1,84 & 2,32 & 0,476945 & 0,1331 & 0,063481 \\
\hline 9 & 1,86 & 2,24 & 0,378734 & 0,1179 & 0,044653 \\
\hline 10 & 1,88 & 2,23 & 0,349447 & 0,1036 & 0,036203 \\
\hline 11 & 1,89 & 2,18 & 0,29532 & 0,09 & 0,026579 \\
\hline 12 & 1,89 & 2,18 & 0,291782 & 0,077 & 0,022467 \\
\hline 13 & 1,94 & 2,18 & 0,239487 & 0,0645 & 0,015447 \\
\hline 14 & 1,94 & 2,13 & 0,189905 & 0,0523 & 0,009932 \\
\hline 15 & 1,96 & 2,12 & 0,164724 & 0,0404 & 0,006655 \\
\hline 16 & 1,98 & 2,12 & 0,142 & 0,0287 & 0,004075 \\
\hline 17 & 1,98 & 2,11 & 0,133111 & 0,0172 & 0,00229 \\
\hline 18 & 1,98 & 1,99 & 0,012 & 0,0057 & $6,84 \mathrm{E}-05$ \\
\hline & & & & SW & 2,339901 \\
\hline
\end{tabular}

SQT $\quad 5,765773$

W $\quad 0,949593$

$\begin{array}{lll}\text { Para alfa }=0,05 & \text { Ws } & 0,935\end{array}$

$\mathrm{W}>$ Ws Aceitar normalidade 
- Histogramas e verificações de normalidade para a propriedade índice de forma:

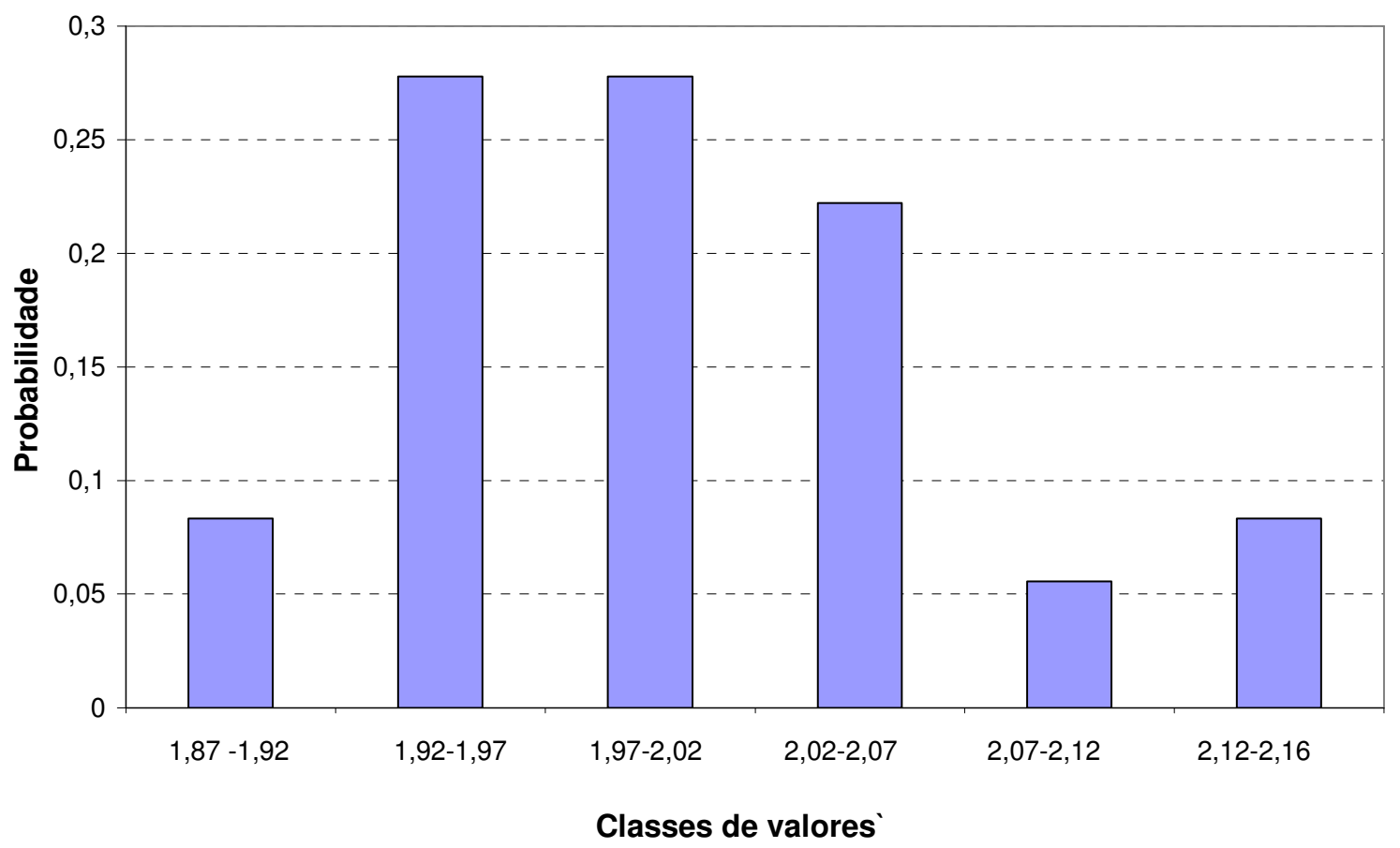

TESTE DE NORMALIDADE SHAPIRO-WILK índice de forma

\begin{tabular}{|r|r|r|r|r|r|}
\hline & \multicolumn{1}{|l|}{ xi } & x37-i & x37-i-xi & ai & ai(x37-i-xi) \\
\hline 1 & 1,87 & 2,16 & 0,29 & 0,4068 & 0,117972 \\
\hline 2 & 1,90 & 2,14 & 0,24 & 0,2813 & 0,067512 \\
\hline 3 & 1,92 & 2,14 & 0,22 & 0,2415 & 0,05313 \\
\hline 4 & 1,93 & 2,12 & 0,19 & 0,2121 & 0,040299 \\
\hline 5 & 1,94 & 2,08 & 0,14 & 0,1883 & 0,026362 \\
\hline 6 & 1,95 & 2,07 & 0,12 & 0,1678 & 0,020136 \\
\hline 7 & 1,95 & 2,06 & 0,11 & 0,1496 & 0,016456 \\
\hline 8 & 1,95 & 2,06 & 0,11 & 0,1331 & 0,014641 \\
\hline 9 & 1,95 & 2,05 & 0,1 & 0,1179 & 0,01179 \\
\hline 10 & 1,96 & 2,05 & 0,09 & 0,1036 & 0,009324 \\
\hline 11 & 1,96 & 2,05 & 0,09 & 0,09 & 0,0081 \\
\hline 12 & 1,97 & 2,04 & 0,07 & 0,077 & 0,00539 \\
\hline 13 & 1,97 & 2,03 & 0,06 & 0,0645 & 0,00387 \\
\hline 14 & 1,98 & 2,02 & 0,04 & 0,0523 & 0,002092 \\
\hline 15 & 1,98 & 2,02 & 0,04 & 0,0404 & 0,001616 \\
\hline 16 & 1,98 & 2,01 & 0,03 & 0,0287 & 0,000861 \\
\hline 17 & 1,98 & 2,01 & 0,03 & 0,0172 & 0,000516 \\
\hline 18 & 1,99 & 2,00 & 0,01 & 0,0057 & $5,7 \mathrm{E}-05$ \\
\hline \multicolumn{7}{|c|}{ SW } & \multicolumn{3}{c}{0,400124} \\
\hline
\end{tabular}

SQT

0,1656

W $\quad 0,966783$

$\begin{array}{lll}\text { Para alfa }=0,05 \quad \text { Ws } & 0,935\end{array}$

W $>$ Ws Aceitar normalidade 
- Histogramas e verificações de normalidade para a propriedade granulometria:

Porcentagem retida no fundo

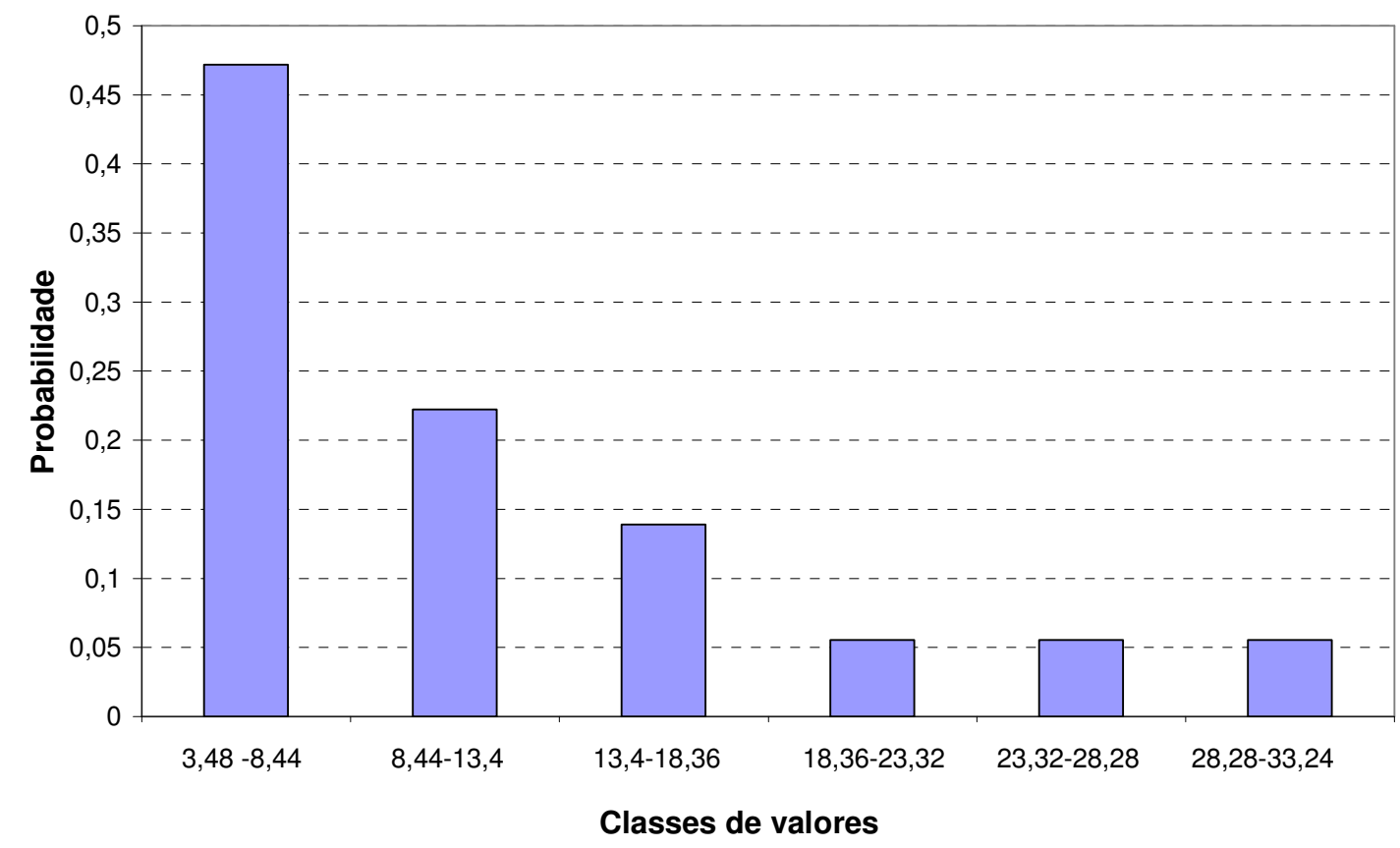

TESTE DE NORMALIDADE SHAPIRO-WILK $\%$ retida no fundo

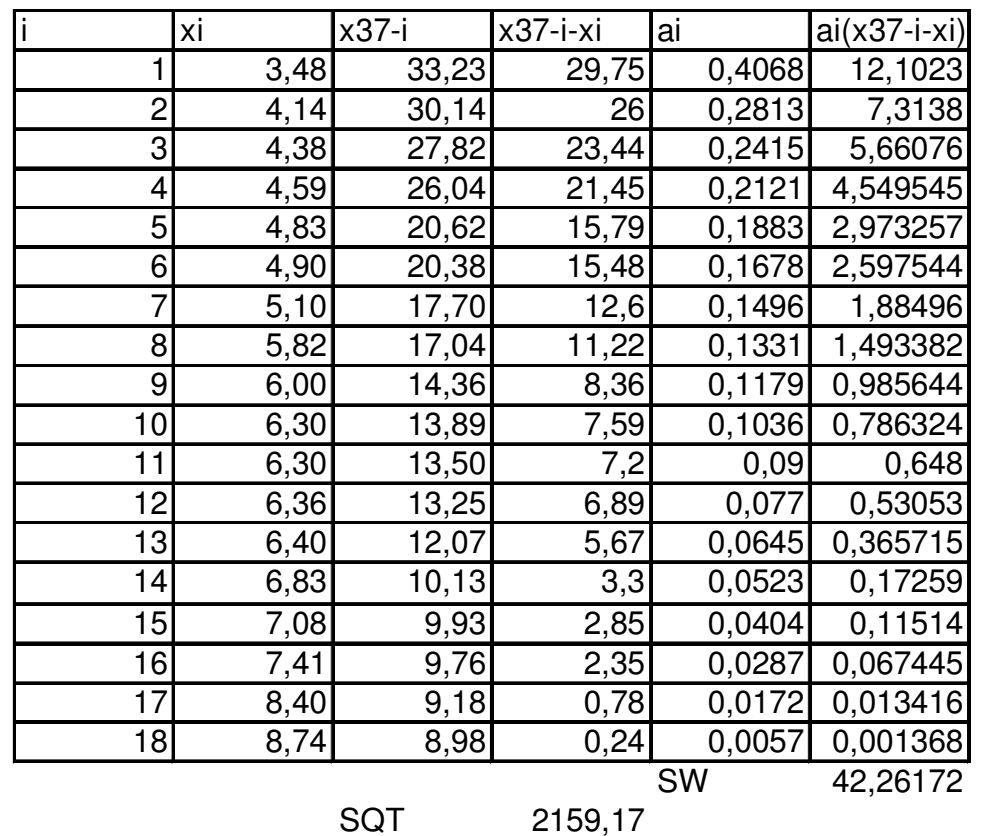

W $\quad 0,827194$

Para alfa $=0,05 \quad$ Ws $\quad 0,935$

\section{W $<$ Ws Não aceitar normalidade}


Porcentagem passante na peneira com abertura de malha $4,8 \mathrm{~mm}$

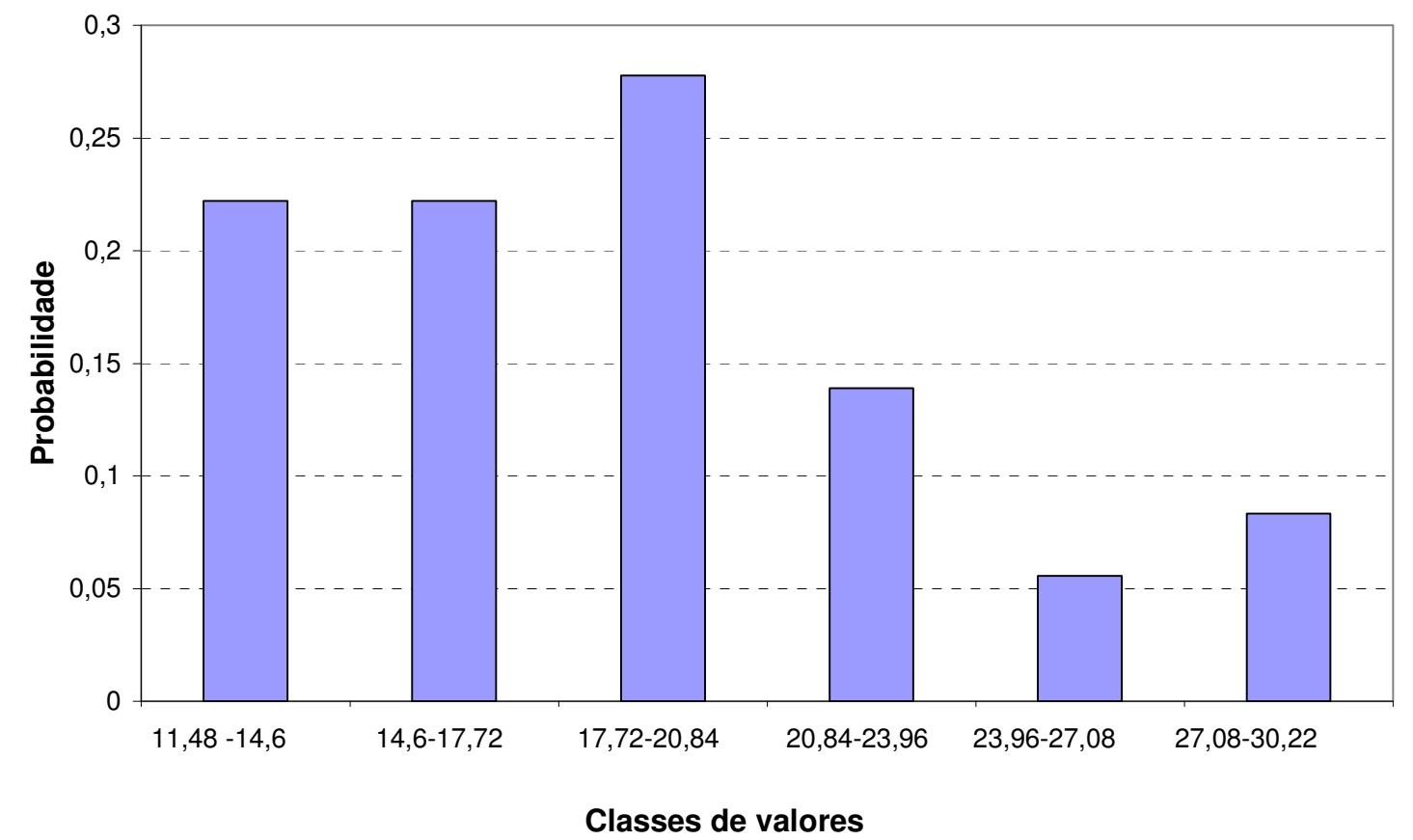

TESTE DE NORMALIDADE SHAPIRO-WILK

$\%$ passante na peneira com abertura de malha $4,8 \mathrm{~mm}$

\begin{tabular}{|r|r|r|r|r|r|}
\hline i & xi & x37-i & x37-i-xi & ai & ai(x37-i-xi) \\
\hline 1 & 11,48 & 30,22 & 18,74 & 0,4068 & 7,623432 \\
\hline 2 & 12,07 & 28,21 & 16,14 & 0,2813 & 4,540182 \\
\hline 3 & 12,61 & 27,13 & 14,52 & 0,2415 & 3,50658 \\
\hline 4 & 13,02 & 25,22 & 12,2 & 0,2121 & 2,58762 \\
\hline 5 & 13,74 & 24,31 & 10,57 & 0,1883 & 1,990331 \\
\hline 6 & 13,89 & 23,24 & 9,35 & 0,1678 & 1,56893 \\
\hline 7 & 14,36 & 23,14 & 8,78 & 0,1496 & 1,313488 \\
\hline 8 & 14,48 & 22,70 & 8,22 & 0,1331 & 1,094082 \\
\hline 9 & 14,79 & 22,09 & 7,3 & 0,1179 & 0,86067 \\
\hline 10 & 15,03 & 21,62 & 6,59 & 0,1036 & 0,682724 \\
\hline 11 & 15,08 & 19,76 & 4,68 & 0,09 & 0,4212 \\
\hline 12 & 16,56 & 18,79 & 2,23 & 0,077 & 0,17171 \\
\hline 13 & 16,67 & 18,75 & 2,08 & 0,0645 & 0,13416 \\
\hline 14 & 17,48 & 18,57 & 1,09 & 0,0523 & 0,057007 \\
\hline 15 & 17,55 & 18,47 & 0,92 & 0,0404 & 0,037168 \\
\hline 16 & 17,64 & 18,36 & 0,72 & 0,0287 & 0,020664 \\
\hline 17 & 18,04 & 18,27 & 0,23 & 0,0172 & 0,003956 \\
\hline 18 & 18,14 & 18,16 & 0,02 & 0,0057 & 0,000114 \\
\hline \multicolumn{5}{|c}{ SW } & \multicolumn{5}{|c}{26,61402} \\
\hline \multicolumn{7}{|c|}{ SQT } & 751,0488 & \\
\hline
\end{tabular}

W $\quad 0,943089$

Para alfa $=0,05 \quad$ Ws $\quad 0,935$

W $>$ Ws Aceitar normalidade 
Porcentagem passante na peneira com abertura de malha 6,25mm

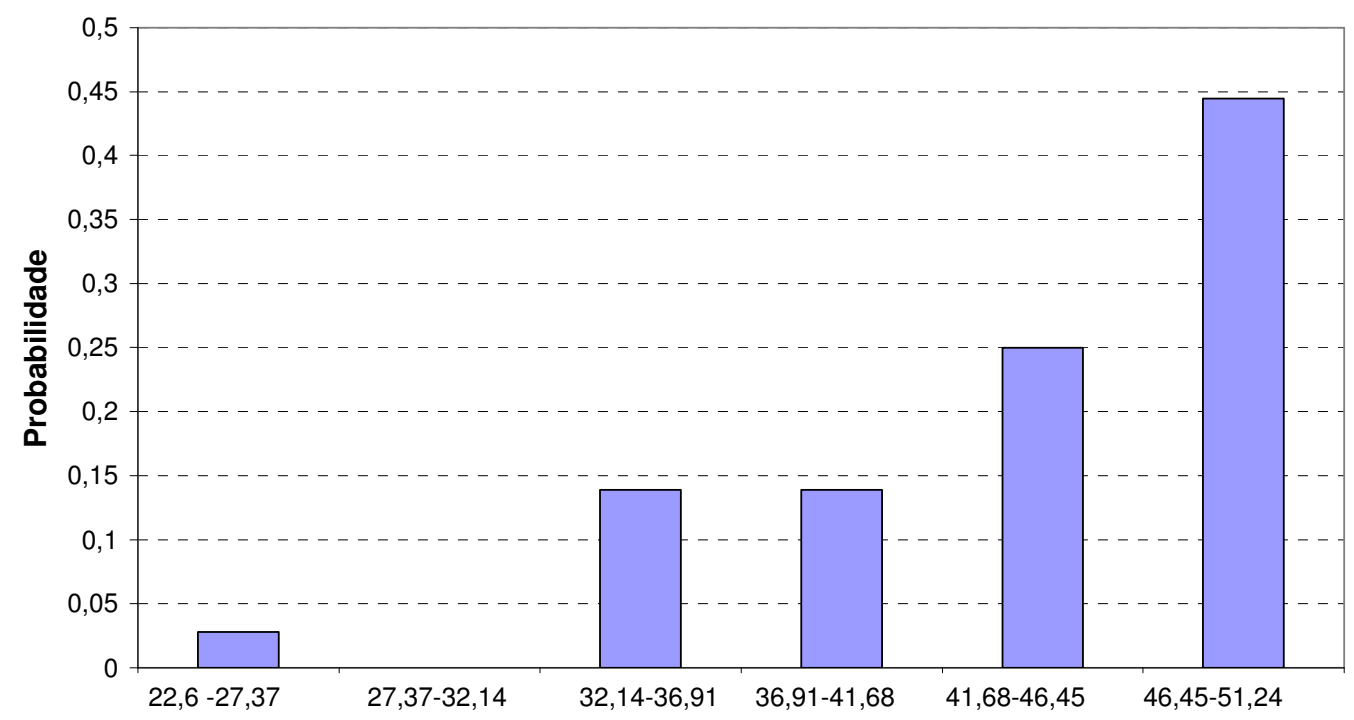

Classes de valores

TESTE DE NORMALIDADE SHAPIRO-WILK $\%$ passante na peneira com abertura de malha $6,25 \mathrm{~mm}$

\begin{tabular}{|r|r|r|r|r|r|}
\hline$i$ & $x i$ & \multicolumn{1}{l|}{ x37-i } & x37-i-xi & ai & ai(x37-i-xi) \\
\hline 1 & 22,6 & 51,24 & 28,64 & 0,4068 & 11,65075 \\
\hline 2 & 34,59 & 50,55 & 15,96 & 0,2813 & 4,489548 \\
\hline 3 & 34,83 & 49,38 & 14,55 & 0,2415 & 3,513825 \\
\hline 4 & 35,45 & 48,98 & 13,53 & 0,2121 & 2,869713 \\
\hline 5 & 35,77 & 48,66 & 12,89 & 0,1883 & 2,427187 \\
\hline 6 & 36,7 & 48,65 & 11,95 & 0,1678 & 2,00521 \\
\hline 7 & 38,42 & 48,58 & 10,16 & 0,1496 & 1,519936 \\
\hline 8 & 38,49 & 48,29 & 9,8 & 0,1331 & 1,30438 \\
\hline 9 & 39,28 & 48,18 & 8,9 & 0,1179 & 1,04931 \\
\hline 10 & 41,38 & 48,06 & 6,68 & 0,1036 & 0,692048 \\
\hline 11 & 41,47 & 48,01 & 6,54 & 0,09 & 0,5886 \\
\hline 12 & 42,59 & 47,91 & 5,32 & 0,077 & 0,40964 \\
\hline 13 & 43,54 & 47,71 & 4,17 & 0,0645 & 0,268965 \\
\hline 14 & 43,97 & 47,64 & 3,67 & 0,0523 & 0,191941 \\
\hline 15 & 44,67 & 47,09 & 2,42 & 0,0404 & 0,097768 \\
\hline 16 & 44,73 & 46,72 & 1,99 & 0,0287 & 0,057113 \\
\hline 17 & 45 & 46,04 & 1,04 & 0,0172 & 0,017888 \\
\hline 18 & 45,32 & 46,02 & 0,7 & 0,0057 & 0,00399 \\
\hline \multicolumn{7}{|c}{ SW } & \multicolumn{3}{|c}{33,15781} \\
\hline
\end{tabular}

SQT $\quad 1275,439$

W $\quad 0,86201$

Para alfa $=0,05 \quad$ Ws $\quad 0,935$

W $<$ Ws Não aceitar normalidade 
Porcentagem passante na peneira com abertura de malha 9,5mm

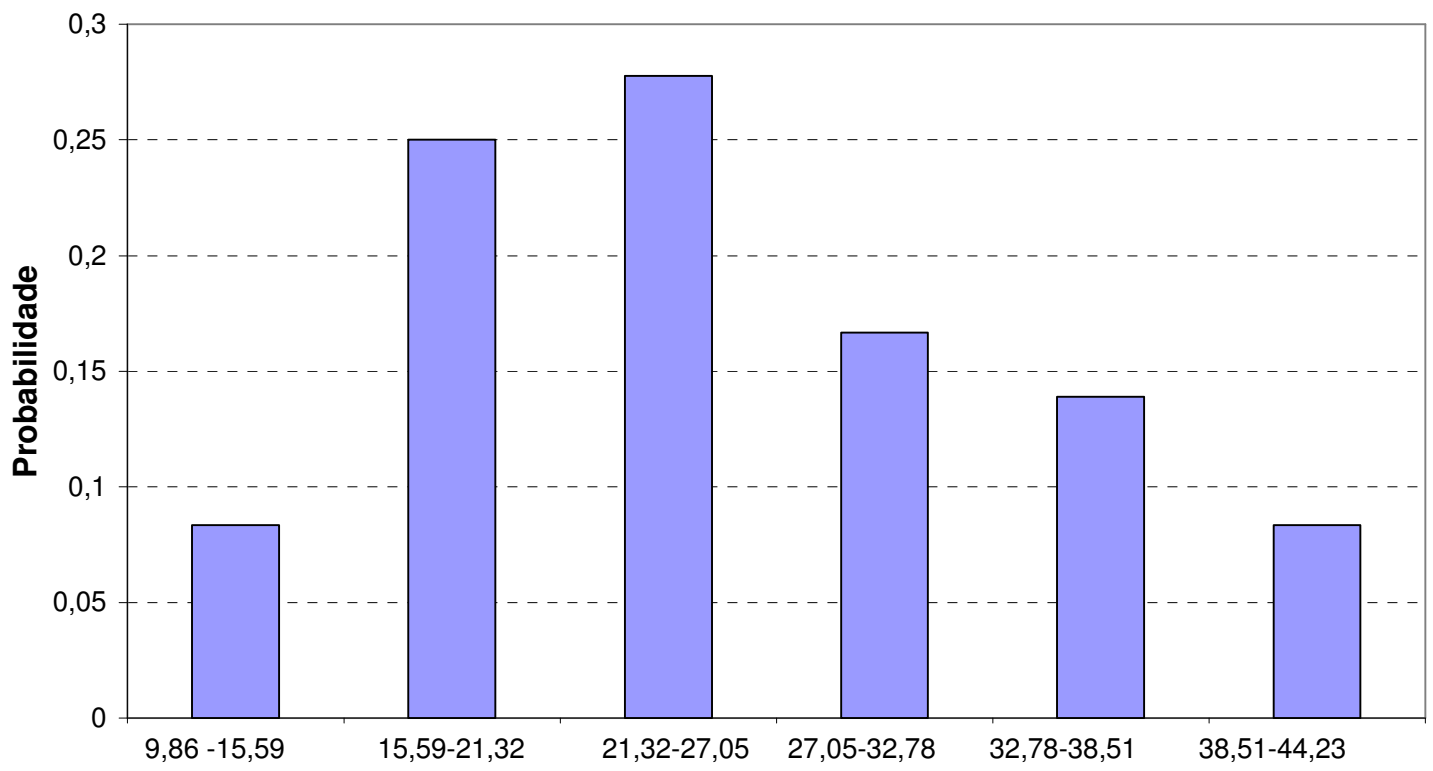

Classes de valores

TESTE DE NORMALIDADE SHAPIRO-WILK

$\%$ passante na peneira com abertura de malha $9,5 \mathrm{~mm}$

\begin{tabular}{|r|r|r|r|r|r|}
\hline & xi & x37-i & x37-i-xi & ai & ai $\times 37-i-x i)$ \\
\hline 1 & 9,86 & 44,23 & 34,37 & 0,4068 & 13,98172 \\
\hline 2 & 13,89 & 40,16 & 26,27 & 0,2813 & 7,389751 \\
\hline 3 & 14,41 & 39,02 & 24,61 & 0,2415 & 5,943315 \\
\hline 4 & 15,72 & 36,33 & 20,61 & 0,2121 & 4,371381 \\
\hline 5 & 16,73 & 35,33 & 18,6 & 0,1883 & 3,50238 \\
\hline 6 & 18 & 34,49 & 16,49 & 0,1678 & 2,767022 \\
\hline 7 & 18,55 & 34,2 & 15,65 & 0,1496 & 2,34124 \\
\hline 8 & 18,56 & 34,17 & 15,61 & 0,1331 & 2,077691 \\
\hline 9 & 19,71 & 32,3 & 12,59 & 0,1179 & 1,484361 \\
\hline 10 & 20,21 & 31,4 & 11,19 & 0,1036 & 1,159284 \\
\hline 11 & 20,26 & 31,08 & 10,82 & 0,09 & 0,9738 \\
\hline 12 & 20,88 & 28,75 & 7,87 & 0,077 & 0,60599 \\
\hline 13 & 21,9 & 27,85 & 5,95 & 0,0645 & 0,383775 \\
\hline 14 & 22,8 & 27,65 & 4,85 & 0,0523 & 0,253655 \\
\hline 15 & 23,25 & 26,64 & 3,39 & 0,0404 & 0,136956 \\
\hline 16 & 23,37 & 26,52 & 3,15 & 0,0287 & 0,090405 \\
\hline 17 & 23,95 & 25,71 & 1,76 & 0,0172 & 0,030272 \\
\hline 18 & 24,26 & 25,25 & 0,99 & 0,0057 & 0,005643 \\
\hline \multicolumn{7}{|c|}{ SW } & 47,49864 \\
\hline
\end{tabular}

SQT $\quad 2298,774$

W

0,981445

Para alfa $=0,05$

Ws

0,935

$\mathrm{W}>\mathrm{Ws}$

Aceitar normalidade 
- Histogramas e verificações de normalidade para a propriedade composição em função das fases:

\section{Concreto}

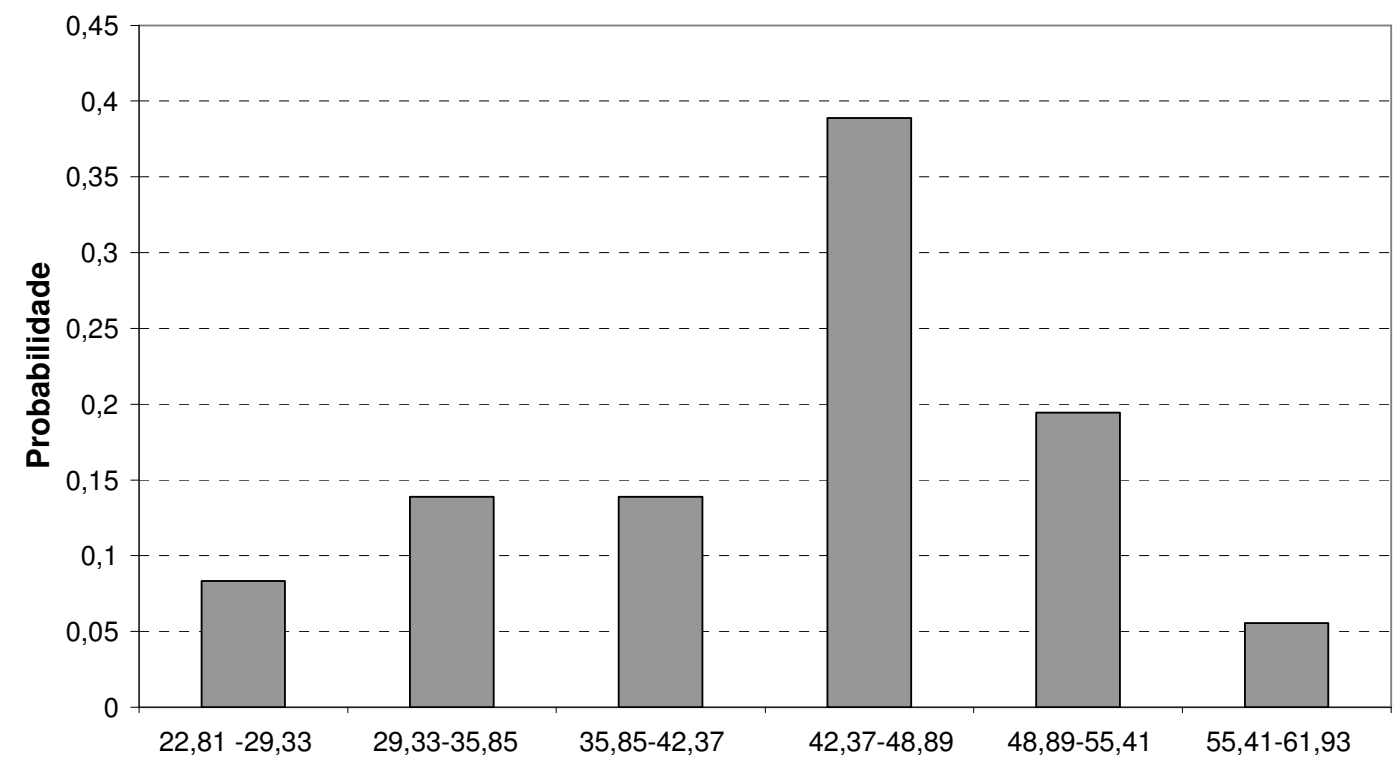

Classes de valores

TESTE DE NORMALIDADE SHAPIRO-WILK concreto

\begin{tabular}{|r|r|r|r|r|r|}
\hline$i$ & xi & x37-i & x37-i-xi & ai & ai(x37-i-xi) \\
\hline 1 & 22,81 & 61,90 & 39,0958 & 0,4068 & 15,90417 \\
\hline 2 & 25,07 & 57,10 & 32,0325 & 0,2813 & 9,010742 \\
\hline 3 & 27,54 & 55,39 & 27,8572 & 0,2415 & 6,727514 \\
\hline 4 & 31,61 & 55,00 & 23,3883 & 0,2121 & 4,960658 \\
\hline 5 & 32,47 & 54,36 & 21,8962 & 0,1883 & 4,123054 \\
\hline 6 & 32,76 & 52,50 & 19,7392 & 0,1678 & 3,312238 \\
\hline 7 & 33,69 & 51,19 & 17,5045 & 0,1496 & 2,618673 \\
\hline 8 & 34,10 & 50,44 & 16,3306 & 0,1331 & 2,173603 \\
\hline 9 & 36,20 & 50,13 & 13,9314 & 0,1179 & 1,642512 \\
\hline 10 & 39,48 & 48,69 & 9,204 & 0,1036 & 0,953534 \\
\hline 11 & 39,74 & 48,53 & 8,7904 & 0,09 & 0,791136 \\
\hline 12 & 40,02 & 48,25 & 8,2314 & 0,077 & 0,633818 \\
\hline 13 & 41,64 & 47,88 & 6,2386 & 0,0645 & 0,40239 \\
\hline 14 & 43,96 & 47,73 & 3,7633 & 0,0523 & 0,196821 \\
\hline 15 & 44,20 & 47,70 & 3,4948 & 0,0404 & 0,14119 \\
\hline 16 & 44,27 & 46,68 & 2,408 & 0,0287 & 0,06911 \\
\hline 17 & 44,66 & 45,87 & 1,217 & 0,0172 & 0,020932 \\
\hline 18 & 45,57 & 45,83 & 0,2544 & 0,0057 & 0,00145 \\
\hline \multicolumn{7}{|c}{ SW } & \multicolumn{3}{|c}{53,68355} \\
\hline
\end{tabular}

SQT $\quad 2987,748$

W $\quad 0,96458$

$\begin{array}{lll}\text { Para alfa }=0,05 \quad \text { Ws } & 0,935\end{array}$

W $>$ Ws Aceitar normalidade 
Argamassa

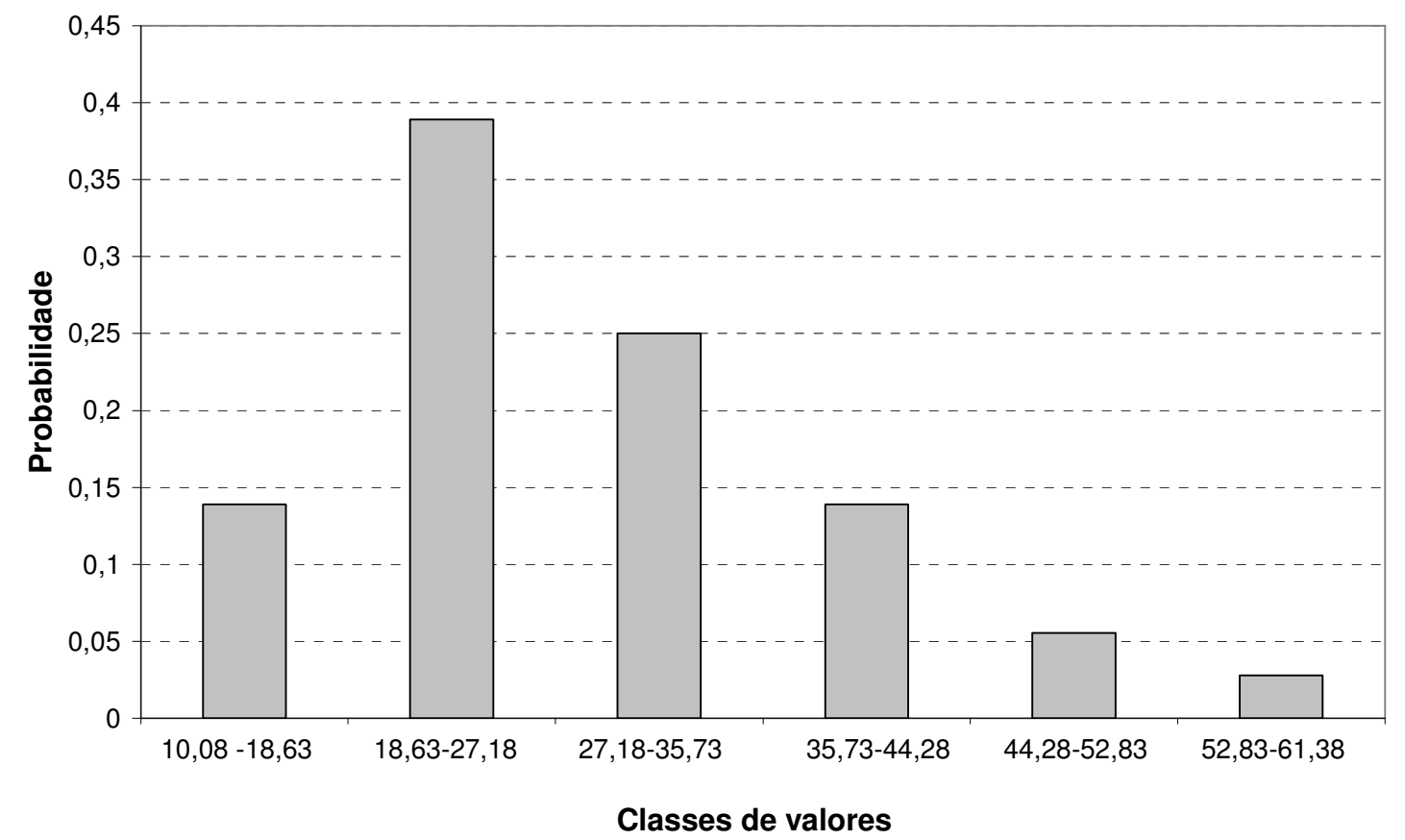

TESTE DE NORMALIDADE SHAPIRO-WILK argamassa

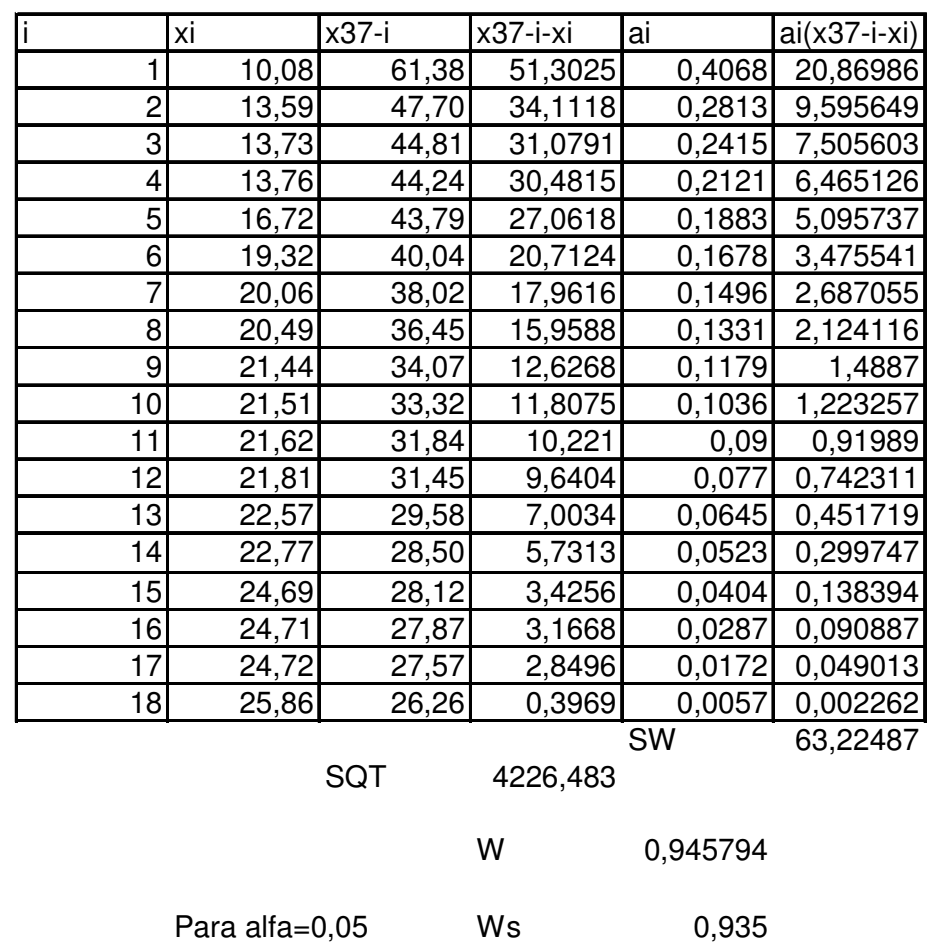

W $>$ Ws Aceitar normalidade 
Rochas

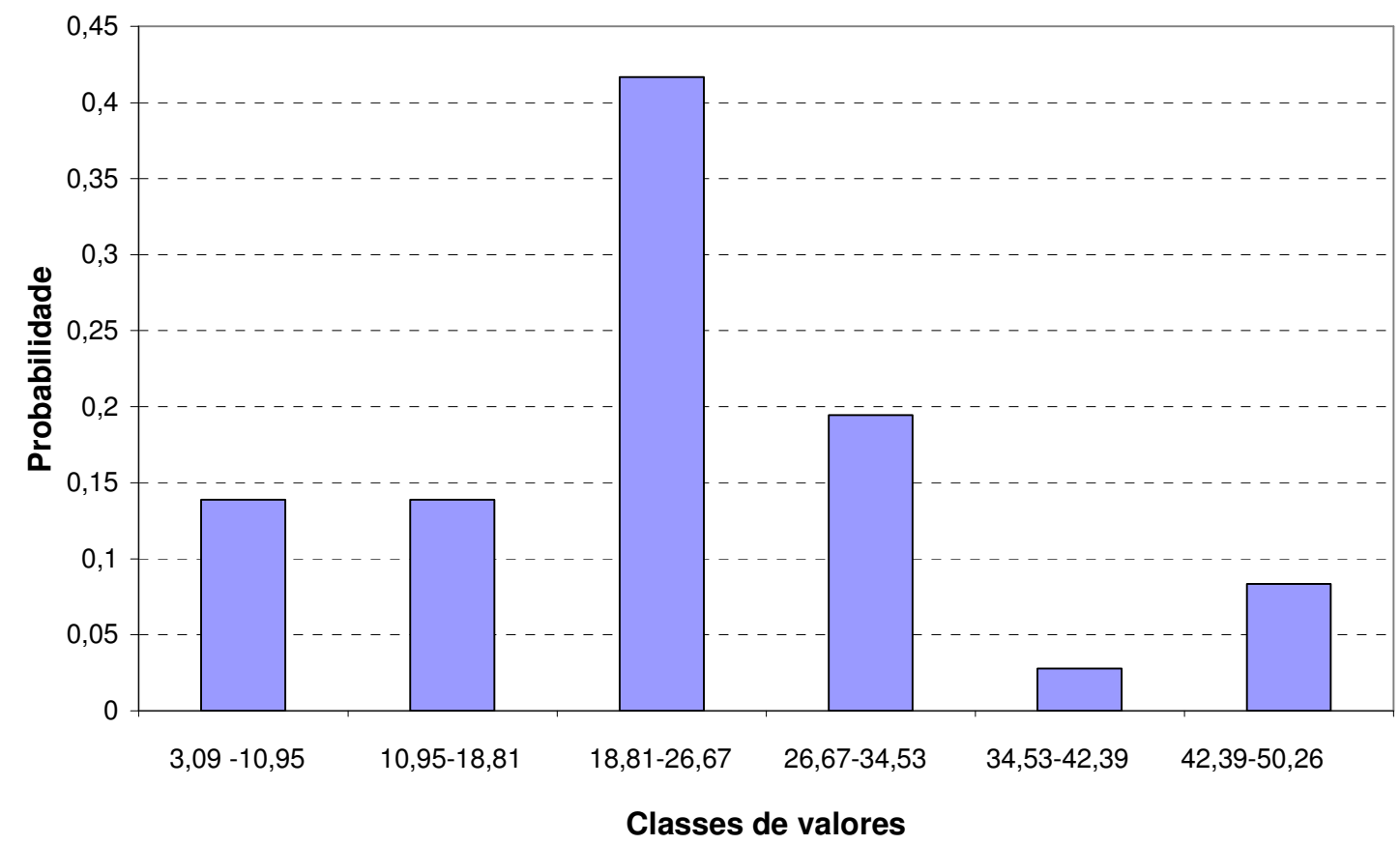

TESTE DE NORMALIDADE SHAPIRO-WILK rochas

\begin{tabular}{|c|c|c|c|c|c|}
\hline & $x i$ & $x 37-i$ & $x 37-i-x i$ & ai & \begin{tabular}{|l}
$a i(x 37-i-x i)$ \\
\end{tabular} \\
\hline 1 & 3,09 & \begin{tabular}{|r|}
50,26 \\
\end{tabular} & $\begin{array}{r}47,17 \\
\end{array}$ & 0,4068 & \begin{tabular}{|l|}
19,18876 \\
\end{tabular} \\
\hline 2 & 3,40 & 48,94 & 45,54 & 0,2813 & 12,8104 \\
\hline 3 & 6,63 & 44,28 & 37,65 & 0,2415 & 9,092475 \\
\hline 4 & 8,63 & 36,78 & 28,15 & 0,2121 & 5,970615 \\
\hline 5 & 9,41 & 33,71 & 24,3 & 0,1883 & 4,57569 \\
\hline 6 & 11,15 & 32,66 & 21,51 & 0,1678 & 3,609378 \\
\hline 7 & 11,32 & 30,81 & 19,49 & 0,1496 & 2,915704 \\
\hline 8 & 12,43 & 30,38 & 17,95 & 0,1331 & 2,389145 \\
\hline 9 & 12,83 & 30,13 & 17,3 & 0,1179 & 2,03967 \\
\hline 10 & 17,85 & 28,62 & 10,77 & 0,1036 & 1,115772 \\
\hline 11 & 19,19 & 28,43 & 9,24 & 0,09 & 0,8316 \\
\hline 12 & 20 & 25,06 & 5,06 & 0,077 & 0,38962 \\
\hline 13 & 20,72 & 24,50 & 3,78 & 0,0645 & 0,24381 \\
\hline 14 & 20,77 & 24,01 & 3,24 & 0,0523 & 0,169452 \\
\hline 15 & 21,12 & 23,95 & 2,83 & 0,0404 & 0,114332 \\
\hline 16 & 21,36 & 23,34 & 1,98 & 0,0287 & 0,056826 \\
\hline 17 & 22,25 & 23,01 & 0,76 & 0,0172 & 0,013072 \\
\hline 18 & 22,33 & 22,96 & 0,63 & 0,0057 & 0,003591 \\
\hline & & & 4501,733 & & \\
\hline
\end{tabular}

W $\quad 0,953893$

$\begin{array}{lll}\text { Para alfa }=0,05 \quad \text { Ws } & 0,935\end{array}$

$\mathrm{W}>\mathrm{Ws} \quad$ Aceitar normalidade 


\section{Cerâmicas}

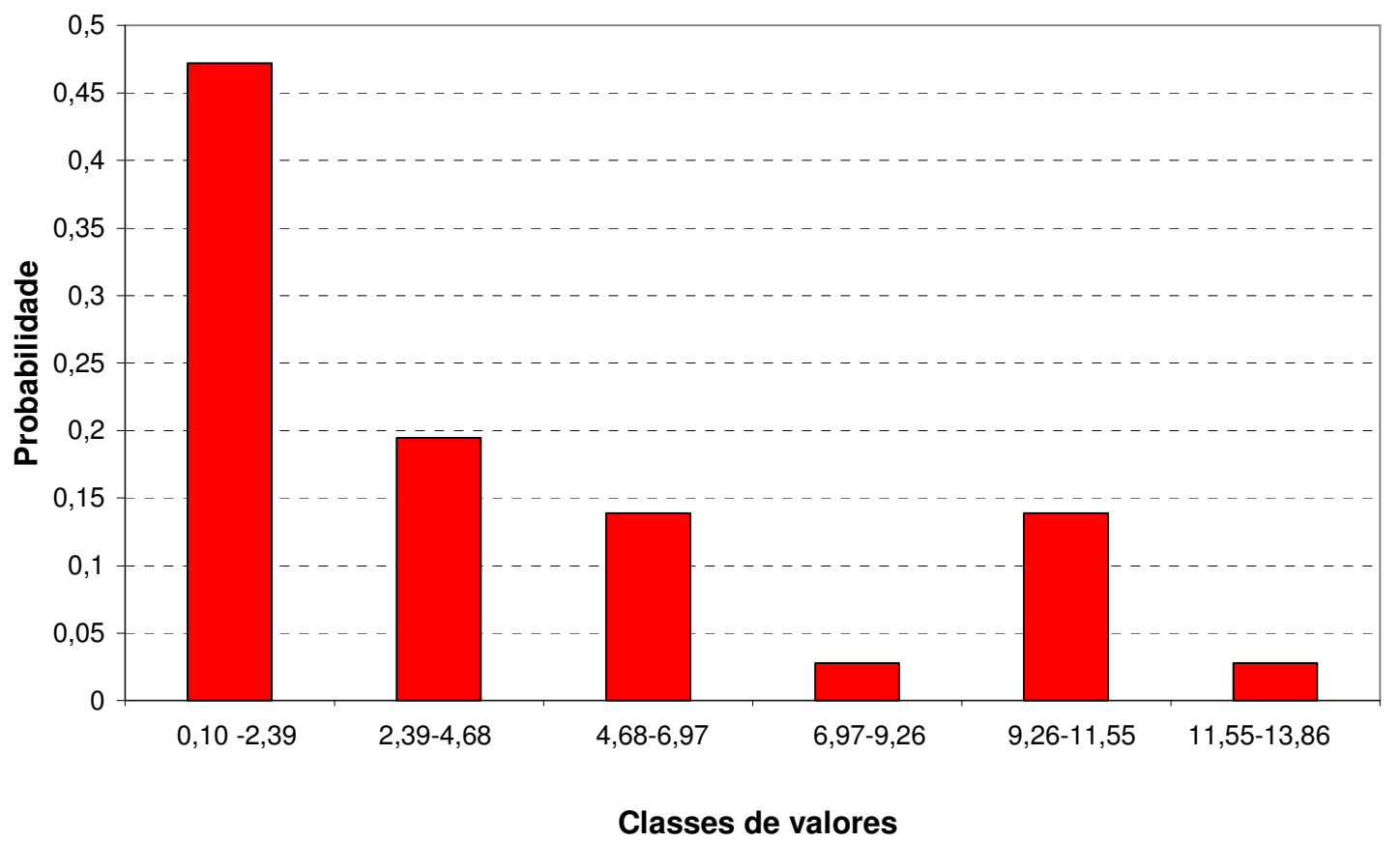

TESTE DE NORMALIDADE SHAPIRO-WILK cerâmicas

\begin{tabular}{|r|r|r|r|r|r|}
\hline i & xi & x37-i & x37-i-xi & ai & ai (x37-i-xi) \\
\hline 1 & 0,10 & 13,86 & 13,76 & 0,4068 & 5,597568 \\
\hline 2 & 0,22 & 11,11 & 10,89 & 0,2813 & 3,063357 \\
\hline 3 & 0,24 & 10,24 & 10 & 0,2415 & 2,415 \\
\hline 4 & 0,31 & 9,93 & 9,62 & 0,2121 & 2,040402 \\
\hline 5 & 0,33 & 9,81 & 9,48 & 0,1883 & 1,785084 \\
\hline 6 & 0,46 & 9,55 & 9,09 & 0,1678 & 1,525302 \\
\hline 7 & 0,47 & 7,79 & 7,32 & 0,1496 & 1,095072 \\
\hline 8 & 0,58 & 6,44 & 5,86 & 0,1331 & 0,779966 \\
\hline 9 & 0,64 & 6,17 & 5,53 & 0,1179 & 0,651987 \\
\hline 10 & 0,68 & 5,84 & 5,16 & 0,1036 & 0,534576 \\
\hline 11 & 0,77 & 5,48 & 4,71 & 0,09 & 0,4239 \\
\hline 12 & 1,53 & 5,30 & 3,77 & 0,077 & 0,29029 \\
\hline 13 & 1,62 & 4,3 & 2,68 & 0,0645 & 0,17286 \\
\hline 14 & 1,73 & 3,96 & 2,23 & 0,0523 & 0,116629 \\
\hline 15 & 2,02 & 3,79 & 1,77 & 0,0404 & 0,071508 \\
\hline 16 & 2,03 & 3,04 & 1,01 & 0,0287 & 0,028987 \\
\hline 17 & 2,17 & 2,66 & 0,49 & 0,0172 & 0,008428 \\
\hline 18 & 2,42 & 2,49 & 0,07 & 0,0057 & 0,000399 \\
\hline \multicolumn{5}{|c}{ SW } & 20,60132 \\
\hline \multicolumn{7}{|c|}{ SQT } & 494,1512 & & \\
\hline
\end{tabular}

W $\quad 0,858875$

$\begin{array}{lll}\text { Para alfa }=0,05 \quad \text { Ws } & 0,935\end{array}$

W $<$ Ws Não aceitar normalidade 
Materiais betuminosos

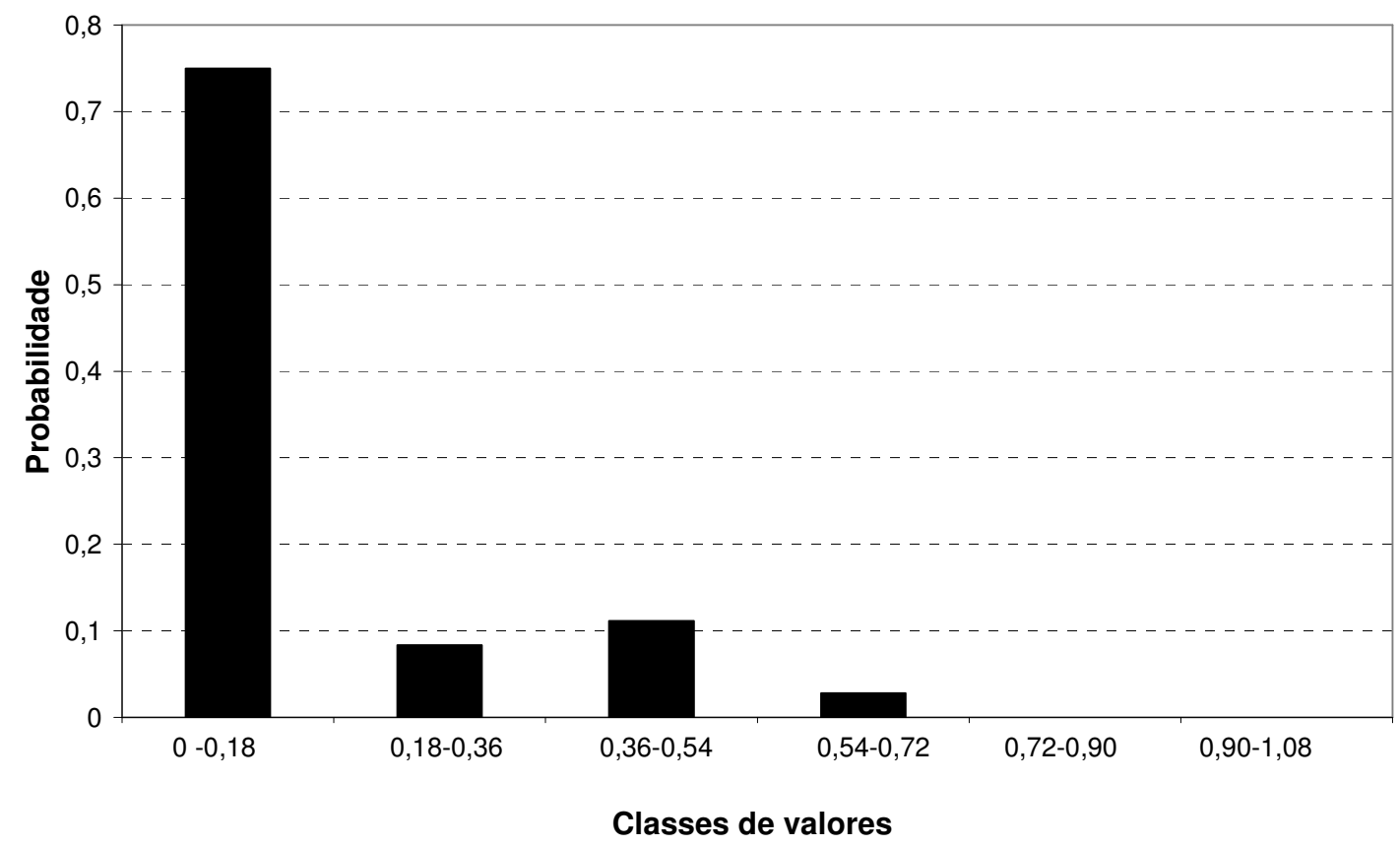

TESTE DE NORMALIDADE SHAPIRO-WILK materiais betuminosos

\begin{tabular}{|c|c|c|c|c|c|}
\hline & $x i$ & $\times 37-i$ & x37-i-xi & ai & $a i(x 37-i-x i)$ \\
\hline 1 & 0 & 0,08 & 0,08 & 0,4068 & 0,032544 \\
\hline 2 & 0,00 & 1,09 & 1,09 & 0,2813 & 0,306617 \\
\hline 3 & 0,00 & 0,70 & 0,7 & 0,2415 & 0,16905 \\
\hline 4 & 0,00 & 0,53 & 0,53 & 0,2121 & 0,112413 \\
\hline 5 & 0,00 & 0,47 & 0,47 & 0,1883 & 0,088501 \\
\hline$\overline{6}$ & 0 & 0,41 & 0,41 & 0,1678 & 0,068798 \\
\hline 7 & 0,00 & 0,41 & 0,41 & 0,1496 & 0,061336 \\
\hline 8 & 0,00 & 0,28 & 0,28 & 0,1331 & 0,037268 \\
\hline 9 & 0,01 & 0,19 & 0,18 & 0,1179 & 0,021222 \\
\hline 10 & 0,02 & 0,19 & 0,17 & 0,1036 & 0,017612 \\
\hline 11 & 0,02 & 0,18 & 0,16 & 0,09 & 0,0144 \\
\hline 12 & 0,03 & 0,16 & 0,13 & 0,077 & 0,01001 \\
\hline 13 & 0,04 & 0,13 & 0,09 & 0,0645 & 0,005805 \\
\hline 14 & 0,04 & 0,12 & 0,08 & 0,0523 & 0,004184 \\
\hline 15 & 0,07 & 0,10 & 0,03 & 0,0404 & 0,001212 \\
\hline 16 & 0,07 & 0,10 & 0,03 & 0,0287 & 0,000861 \\
\hline 17 & 0,07 & 0,09 & 0,02 & 0,0172 & 0,000344 \\
\hline 18 & 0,08 & 0,08 & 0 & 0,0057 & 0 \\
\hline & & & 19014 & & \\
\hline
\end{tabular}

W $\quad 0,476828$

Para alfa $=0,05 \quad$ Ws $\quad 0,935$

W $<$ Ws Não aceitar normalidade 
Outros

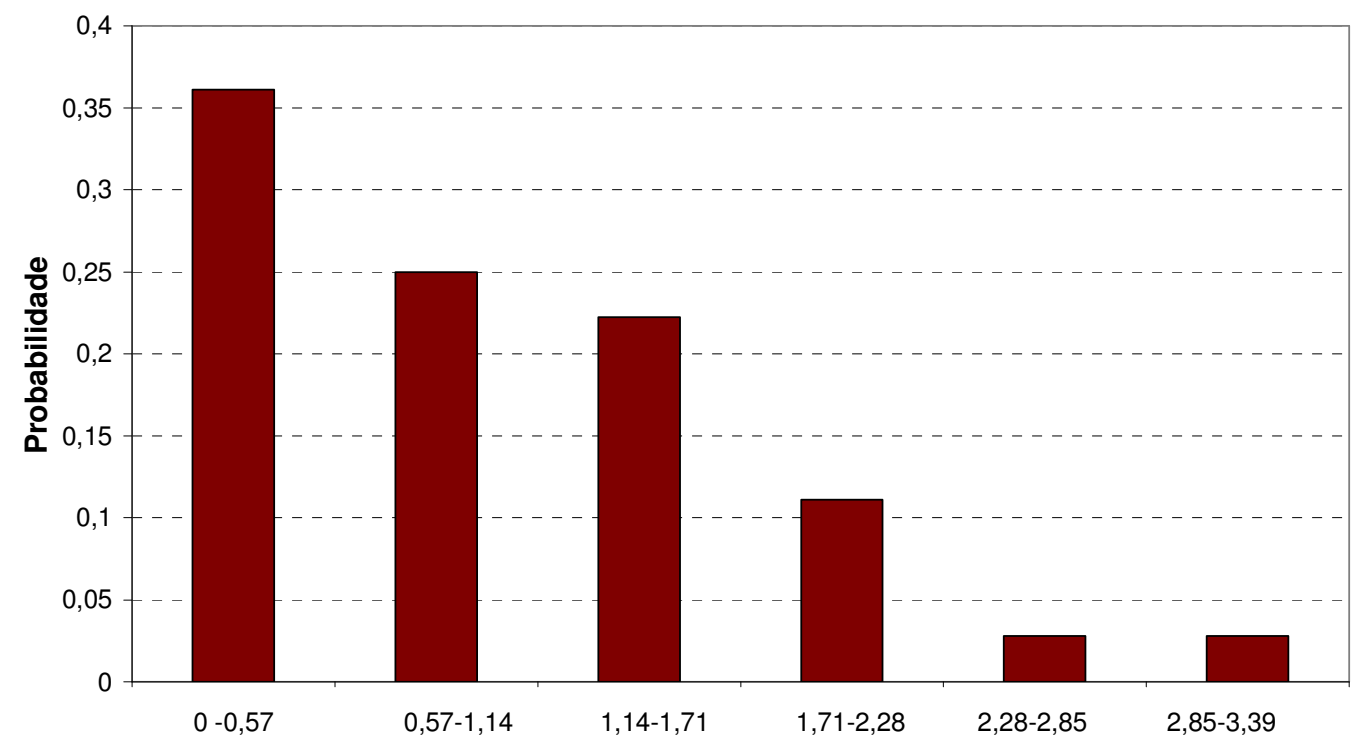

Classes de valores

TESTE DE NORMALIDADE SHAPIRO-WILK outros

\begin{tabular}{|r|r|r|r|r|r|}
\hline & $x i$ & \multicolumn{1}{|l|}{ x37-i } & x37-i-xi & ai & ai (x37-i-xi) \\
\hline 1 & 0,00 & 0,89 & 0,89 & 0,4068 & 0,362052 \\
\hline 2 & 0,04 & 3,39 & 3,35 & 0,2813 & 0,942355 \\
\hline 3 & 0,09 & 2,74 & 2,65 & 0,2415 & 0,639975 \\
\hline 4 & 0,10 & 2,15 & 2,05 & 0,2121 & 0,434805 \\
\hline 5 & 0,14 & 2,02 & 1,88 & 0,1883 & 0,354004 \\
\hline 6 & 0,17 & 1,98 & 1,81 & 0,1678 & 0,303718 \\
\hline 7 & 0,21 & 1,87 & 1,66 & 0,1496 & 0,248336 \\
\hline 8 & 0,31 & 1,65 & 1,34 & 0,1331 & 0,178354 \\
\hline 9 & 0,36 & 1,54 & 1,18 & 0,1179 & 0,139122 \\
\hline 10 & 0,36 & 1,51 & 1,15 & 0,1036 & 0,11914 \\
\hline 11 & 0,36 & 1,35 & 0,99 & 0,09 & 0,0891 \\
\hline 12 & 0,37 & 1,29 & 0,92 & 0,077 & 0,07084 \\
\hline 13 & 0,42 & 1,22 & 0,8 & 0,0645 & 0,0516 \\
\hline 14 & 0,62 & 1,17 & 0,55 & 0,0523 & 0,028765 \\
\hline 15 & 0,71 & 1,15 & 0,44 & 0,0404 & 0,017776 \\
\hline 16 & 0,74 & 1,07 & 0,33 & 0,0287 & 0,009471 \\
\hline 17 & 0,77 & 1,03 & 0,26 & 0,0172 & 0,004472 \\
\hline 18 & 0,81 & 0,96 & 0,15 & 0,0057 & 0,000855 \\
\hline \multicolumn{7}{|c|}{ SW } & 3,99474 \\
\hline
\end{tabular}

SQT $\quad 22,55022$

W $\quad 0,707663$

$\begin{array}{lll}\text { Para alfa }=0,05 \quad \text { Ws } & 0,935\end{array}$

W $<$ Ws Não aceitar normalidade 


\section{REFERÊNCIAS BIBLIOGRÁFICAS}

ASSOCIAÇÃO BRASILEIRA DE NORMAS TÉCNICAS. Amostragem de agregados - NBR 7216. Rio de Janeiro, 1987.

Agregados - determinação da composição granulométrica - NBR 7217. Rio de Janeiro, 1987.

Agregados - determinação do teor de materiais pulverulentos - NBR 7219. Rio de Janeiro, 1987.

Agregado graúdo - determinação do índice de forma pelo método do paquímetro - NBR 7809. Rio de Janeiro, 1983.

Agregados - determinação da absorção e da massa específica de agregado graúdo - NBR 9937. Rio de Janeiro, 1987.

Redução de amostra de campo de agregados para ensaio de laboratório NBR 9941. Rio de Janeiro, 1987.

Amostragem de resíduos - NBR 10007. Rio de Janeiro.1987.

ANDRADE, A.C. Método para quantificação de perdas de materiais em obras de construção de edifícios. São Paulo, 1999. 235p. Dissertação (Mestrado) - Escola Politécnica, Universidade de São Paulo.

ANDRADE, R.M. et al. On-line measurement of ceramic powder granulometry by computer-aided image analysis. In: WORLD CONGRESS ON CERAMIC TILE QUALITY, 6., Espanha, 2000. Proceedings. Espanha, 2000. p.407-20.

ANGULO, S. C. Produção de concretos com agregados reciclados. Londrina, 1998. 86p. Trabalho de Conclusão de Curso (Engenharia Civil) - Departamento de Construção Civil, Universidade Estadual de Londrina.

, S.C et al. Modelo hierárquico genérico para a gestão de resíduos sólidos urbanos. São Paulo, 1999. 22p. Trabalho disciplina (PCC 5042) - Escola Politécnica, Universidade de São Paulo.

BARRA, M. Estudio de la durabilidad del hormigón de árido reciclado en su aplicación como hormigón armado. Barcelona, 1996. 222p. Tese (Doutorado) Universidade Politécnica da Catalunya.

BARRA, Marilda. Dosagem de concretos com agregados reciclados: aspectos particulares. In: RECICLAGEM NA CONSTRUÇÃO CIVIL, ALTERNATIVA 
ECONÔMICA PARA PROTEÇÃO AMBIENTAL. São Paulo, 1997. Anais. São Paulo, PCC/USP, 1997. p.39-43.

BARTON, J.R. et al. Life Cycle Assessment for Waste Management. Waste management, v.16, n.1-3, p.35-50, 1996.

BARKSDALE et al. Measurement of aggregate shape, surface and roughness. Transportation Research Record, n.1301. p.107-116, 1991.

BORGES, M.E. Disposição inadequada: o problema dos lixões no Brasil. In: SEMINÁRIO NACIONAL DE RESÍDUOS SÓLIDOS E LIMPEZA PÚBLICA, 7, Curitiba, 2000. Anais. Curitiba, ABLP, 2000.

BOSSINK,B.A.G.; BROUWERS, H.J.H. Construction waste: quantification and source evaluation. Journal of Construction Engineering and Management, p.55-60, mar., 1996.

BRANDON, P.S. Sustainability in management and organisation: the key issues? In: CIB BUILDING CONGRESS - MATERIALS AND TECHNOLOGIES FOR SUSTAINABLE CONSTRUCTION, Suíça, 1988. Proceedings. Suíça, 1998. p.1739-47.

BRITO, J.A. Cidade versus entulho. In: SEMINÁRIO DE DESENVOLVIMENTO SUSTENTÁVEL E A RECICLAGEM NA CONSTRUÇÃO CIVIL, 2., São Paulo, 1999. Anais. São Paulo, Comitê Técnico CT206 Meio Ambiente (IBRACON), 1999. p.56-67.

CARNEIRO, A.M.P. Contribuição ao estudo da influência do agregado nas propriedades de argamassas compostas a partir de curvas granulométricas. São Paulo, 1999. 170p. Tese (Doutorado) - Escola Politécnica, Universidade de São Paulo.

CARNEIRO, A.P. et al. Caracterização do entulho de Salvador visando a produção de agregado reciclado. In: ENCONTRO NACIONAL DE TECNOLOGIA DO AMBIENTE CONSTRUÍDO, 7. Salvador, 2000. Anais. Salvador, ANTAC, 2000.

CINCOTTO, M.A. Utilização de subprodutos e resíduos na indústria da construção civil. Construção. São Paulo, PINI. n.2480, p.27-30, ago., 1983.

COLLINS, R. Reuse and recycling in construction: BRE case studies. In: INTERNATIONAL CONFERENCE BUILDINGS AND THE ENVIRONMENT, 2., Paris, 1997. Proceedings. Paris, 1997. p.627-34.

COLLINS, R.J. Upgrading the use of recycled aggregates. In: CIB BUILDING CONGRESS - MATERIALS AND TECHNOLOGIES FOR SUSTAINABLE CONSTRUCTION. Suíça, 1998. Proceedings. Suíça, 1998. p.101-06. 
COSTA NETO, P.L.O. Estatística. São Paulo. Ed. Edgard Blücher Ltda. 1977. 264p.

CRAIGHILL, A.L.; POWELL, J.C. Using environmental economics in decision making and policy formulation for sustainable construction waste management. In: WASTE MATERIALS IN CONSTRUCTIONS: PUTTING THEORY INTO PRACTICE. Great Britain, 1997. Proceedings. Great Britain, 1997. p.859-67.

DESSY, P. et al. Analysis of the performance of concrete components made with recyclced aggregates. In: CIB BUILDING CONGRESS - MATERIALS AND TECHNOLOGIES FOR SUSTAINABLE CONSTRUCTION. Suíça, 1998. Proceedings. Suíça, 1998. p.149-56.

DE PAUW,C. Recyclage des Descombres d'Une Ville Sinistree. CSTC, revue n.4, p.12-28. dez., 1982.

DEVORE, J.L. Probability and Statistics for Engineering and the Sciences. $4^{\text {a }}$ edição. U.S.A., Duxbury Press. 1995. 735p.

GABAS, S. G. Análise de imagem aplicada à caracterização de minérios - análise modal e liberação. São Paulo, 1999. 120p. Dissertação (Mestrado) - Escola Politécnica, Universidade de São Paulo.

GALIVAN, R.M.; BERNOLD, L.E. Source evaluation of Solid Waste in Building Construction. Journal of Construction Engineering and Management. p.536552, dez., 1994.

GALLIAS, J.L. Action of gypsum on recycled aggregate concrete. In: CIB BUILDING CONGRESS - MATERIALS AND TECHNOLOGIES FOR SUSTAINABLE CONSTRUCTION. Suíça, 1998. Proceedings. Suíça, 1998. p.175-82.

GUNTHER, W.M.R. Minimização de resíduos e educação ambiental. In: SEMINÁRIO NACIONAL DE RESÍDUOS SÓLIDOS E LIMPEZA PÚBLICA, 7. Curitiba, 2000. Anais. Curitiba, 2000.

GROOT, P.J. et al. Selecting a representative training set for the classification of demolition waste using remote NIR sensing. Analytica Chimica Acta. n.392, p.67-75, 1999.

HAMASSAKI, L.T. et al. Uso do entulho como agregado para argamassas de alvenaria. In: RECICLAGEM NA CONSTRUÇÃ̃O CIVIL, ALTERNATIVA ECONÔMICA PARA PROTEÇÃO AMBIENTAL. São Paulo, 1997. Anais. São Paulo (EPUSP), 1997. p.11-20.

HANSEN, T.C. RILEM Report 6 - Recycling of Demolished Concrete and Mansory. London, E\& FN SPON na imprint of Chapman \& Hall. 1992. 305p.

HARDER, M.K.; FREEMAN, L.A. Analysis of the volume and composition of construction waste arriving at landfill. In: SECOND INTERNATIONAL 
CONFERENCE BUILDINGS AND THE ENVIRONMENT. Paris, 1997. Proceedings. Paris, 1997. p.595-602.

IMAGE PRO PLUS. Reference guide. Version 4.0 for Windows. 1998.

JOHN, V.M.J. Panorama sobre a reciclagem de resíduos na construção civil. In: SEMINÁRIO DESENVOLVIMENTO SUSTENTÁVEL E A RECICLAGEM NA CONSTRUÇÃO CIVIL, 2., São Paulo, 1999. Anais. São Paulo, IBRACON, 1999. p.44-55.

JOHN, V.M. Reciclagem de resíduos na construção civil - contribuição à metodologia de pesquisa e desenvolvimento. São Paulo, 2000. 102p. Tese (livre docência) - Escola Politécnica, Universidade de São Paulo.

JONES, M. P. Applied mineralogy - a quantitative approach. USA: Graham \& Trotman. 1987. 259p.

KASAI, Y. Guidelines and the present state of the reuse od demolished concrete in Japan. In: INTERNATIONAL RILEM SYMPOSIUM ON DEMOLITION AND REUSE OF CONCRETE AND MASONRY. Dinamarca, 1994. Proceedings. Dinamarca, 1994. p.93-102.

KIHARA, Y.; MARCIANO, E. Indústria do cimento e meio ambiente - atividades do Comitê Técnico do IBRACON. In: RECICLAGEM NA CONSTRUÇÃO CIVIL, ALTERNATIVA ECONÔMICA PARA PROTEÇÃO AMBIENTAL. São Paulo, 1997. Anais. São Paulo, PCC/USP, 1997. p.20-34.

KIKUCHI, M. et al. The total evaluation of recycled aggregate and recycled concrete. In: INTERNATIONAL RILEM SYMPOSIUM ON DEMOLITION AND REUSE OF CONCRETE AND MASONRY. Dinamarca, 1994. Proceedings. Dinamarca, 1994. p.367-378.

KUO et al. Three-dimensional Image Analysis of aggregate particles form orthogonal projections. Transportation Research Record. n.1526. p.98-103. 1996.

KWAN, A.K.H. et al. Particule shape analysis of coarse aggregate using Digital Image Processing. Cement and Concrete Research. v.29, p.1403-10, 1999.

LAPPONI, J.C. Estatística usando o EXCEL 5 e 7. São Paulo. Lapponi Ltda. 1997. 420 p.

LAURITZEN, K.E. RILEM Buletin - International rilem symposium on demolition and reuse of concrete nad masonry. Materials and Structures. n.27, p.307-30, 1994.

LAURITZEN, K.E. Emergency construction waste management. Safety Science. n.30, p.45-53, 1998. 
LEVY, S.M. Reciclagem do entulho da construção civil, para utilização com agregados para argamassas e concretos. São Paulo, 1997a. 147p. Dissertação (Mestrado) - Escola Politécnica, Universidade de São Paulo.

LEVY, S.M.; HELENE, P.R.L. Reciclagem do entulho em canteiros de obra, influência do material cerâmico na qualidade de novas argamassas. In: RECICLAGEM NA CONSTRUÇÃO CIVIL, ALTERNATIVA ECONÔMICA PARA PROTEÇÃO AMBIENTAL. São Paulo, 1997b. Anais. São Paulo (PCC/EPUSP), 1997b. p.4455.

LI et al. Quantitative Analysis of Aggregate Shape Based on Fractals. ACI Materials Journal. v.90, n.4, p.357-65, 1993.

MASSUNARI, I. S. Plano diretor para disposição final de resíduos sólidos na RMSP. In: SEMINÁRIO NACIONAL DE RESÍDUOS SÓLIDOS E LIMPEZA PÚBLICA, 7. Curitiba, 2000. Anais. Curitiba, ABLP, 2000.

LIMA, J.A.R. Proposição de diretrizes para a produção e normalização de resíduo de construção reciclado e de suas aplicações em argamassas e concretos. São Carlos, 1999. 204p. Dissertação (Mestrado). EESC, Universidade de São Paulo.

MERLET, J.D.; PIMIENTA, P. Mechanical and physico-chemical properties of concrete produced with coarse and fine recycled concrete aggregates. in : INTERNATIONAL RILEM SYMPOSIUM ON DEMOLITION AND REUSE OF CONCRETE NAD MASONRY. Proceedings. 1994.E \& FN SPON. P.343-354.

MEYER,C.;BAXTER,S.;JIN,W. Glascrete - Concrete with crushed waste glass aggregate. In: INTERNATIONAL CONFERENCE ON ENGINEERING MATERIALS. Canadá, 1997. Proceedings. Canadá, 1997. p.735-41.

MORA, C. F. et al. Particule Size Distribution analysis fo coarse aggregate using Digital Image Processing. Cement and Concrete Research. v.28, n.6, p.921-32, 1998.

MIRANDA, L.F.R. Estudo de fatores que influem na fissuração de revestimentos de argamassa com entulho reciclado. São Paulo, 2000. 172p. Dissertação (Mestrado) - Escola Politécnica, Universidade de São Paulo.

MORALES, G.; ANGULO, S.C. Produção de concreto de cimento portland utilizando entulho de obra reciclado. In: ENCONTRO NACIONAL DE TECNOLOGIA DO AMBIENTE CONSTRUÍDO, 7. Salvador, 2000. Anais. Salvador, ANTAC, 2000 .

MULDER, E. Re-use of Sieve sand from demolition waste. In: WASTE MATERIALS IN CONSTRUCTIONS: PUTTING THEORY INTO PRACTICE. Great Britain, 1997. Proceedings. Great Britain, 1997. p.699-704.

ORTH, M.H.A. Plano diretor de limpeza urbana - instrumento de planejamento. In: SEMINÁRIO NACIONAL DE RESÍDUOS SÓLIDOS E LIMPEZA PÚBLICA, 7. Curitiba, 2000. Anais. Curitiba, ABLP, 2000. 
PALIARI, J.C. Metodologia para coleta e análise de informações sobre consumos e perdas de materiais e componentes nos canteiros de obras de edifícios. São Paulo, 1999. 473p. Dissertação (Mestrado) - Escola Politécnica, Universidade de São Paulo.

PENG et al. Strategies for sucessful construction and demolition waste recycling operations. Construction, Management and Economics. n.15, p.49-58, 1997.

PERA, J. State of the art report: use of waste materials in construction in western Europe. In: SEMINÁRIO SOBRE RECICLAGEM E REUTILIZAÇÃO DE RESÍDUOS COMO MATERIAIS DE CONSTRUÇÃO. São Paulo, 1996. Anais. São Paulo (PCC-EPUSP), 1996. p.1-20.

PICCHI, F.A. Sistemas de qualidade: uso em empresas de construção de edifícios. São Paulo. 1993. 462p. Tese (Doutorado) - Escola Politécnica, Universidade de São Paulo.

PINTO, T.P. Utilização de resíduos de construção. Estudo do uso em argamassas. São Carlos. 1986. 137p. Dissertação (Mestrado) - EESC, Universidade de São Paulo.

PINTO,T.P. De volta à questão do desperdício. Construção. p.18-19, nov., 1995.

PINTO, T.P. Metodologia para a gestão diferenciada de resíduos sólidos da construção urbana. São Paulo, 1999. 189p. Tese (Doutorado) - Escola Politécnica, Universidade de São Paulo.

QUEBAUD, M.R.; BUYLE-BODIN,F. A reciclagem de materiais de demolição: utilização dos agregados reciclados no concreto. In: CONGRESSO BRASILEIRO DE CIMENTO(CBC), 5. São Paulo, 1999. Anais. São Paulo, 1999. 14p.

RILEM RECOMMENDATION. Specification for concrete with recycled aggregates. Materials and Structures. n.27, p.557-9, 1994.

RUCH, M. et al. Selective dismantling of buildings: state of the art and new developments in Europe. In: INTERNATIONAL CONFERENCE BUILDINGS AND THE ENVIRONMENT, 2. Paris, 1997. Proceedings. Paris, 1997. p.43340 .

RUSS, J.C. The image processing handbook. 2.ed. U.S.A., CRC Press. 1994. 674p.

SARAIVA, A.G. et al. Estudo de algumas propriedades de interesse da argamassa. In: Simpósio Brasileiro de Tecnologia de Argamassas, 3. Vitória, 1999. Anais. Vitória, ANTAC, 1999.

SCHULTMANN, F. et al. Strategies forr the quality improvement of recycling materials. In: INTERNATIONAL CONFERENCE BUILDINGS AND THE ENVIRONMENT, 2. Paris, 1997. Proceedings. Paris, 1997. p.611-18. 
SCHUURMANS-STEHMANN, A.M. Environmental life cycle analysis of construction products with and without recycling. In: ENVIRONMENTAL ASPECTS OF CONSTRUCTION WITH WASTE MATERIALS. Great Britain, 1994. Proceedings. Great Britain, 1994. p.709-717.

SOUZA, U.E.L. et al. Desperdício de materiais nos canteiros de obras: a quebra do mito. In: SIMPÓSIO NACIONAL - DESPERDÍCIO DE MATERIAIS NOS CANTEIROS DE OBRAS: A QUEBRA DO MITO. São Paulo, 1999. Anais. São Paulo (PCC/EPUSP), 1999. 48p.

TOALDO, E. Para não virar pó. Construção, n.2348, p.10, fev., 1993.

TUKKER, A.; GIELEN, D.J. A Concept for the Environmental Evaluation of Waste Management Benefits. In: ENVIRONMENTAL ASPECTS OF CONSTRUCTION WITH WASTE MTERIALS. Great Britain, 1994. Proceedings. Great Britain, 1994. p.737-47.

TRANKLER, J.O.V et al. The environmental impact of demolition waste - an overview on ten years of research and experience. In: INTERNATIONAL SYMPOSIUM ON BULK “INERT” WASTE: AN OPPORTUNITY FOR USE. Inglaterra, 1995. Proceedings. Inglaterra, 1995.

VIRJLINBG, J.K. An economic model for the sucessful recycling of waste materials. In: WASTE MATERIALS IN CONSTRUCTION. Londres, 1991. Proceedings. Londres, 1991. p.601-18.

VUOLO, J.H. Fundamentos da teoria dos erros. São Paulo, Edgard Blücher Ltda. 1992. 219p.

YAMADA, M. et al. Behaviour of reinforced concrete beams containing recycled coarse aggregate. In: INTERNATIONAL RILEM SYMPOSIUM ON DEMOLITION AND REUSE OF CONCRETE AND MASONRY. Dinamarca, 1994. Proceedings. Dinamarca, 1994. p.333-68.

YANAGI, K. et al. Physical properties of recycled concrete using recycled coarse aggregate made of concrete with finishing materials. in : INTERNATIONAL RILEM SYMPOSIUM ON DEMOLITION AND REUSE OF CONCRETE NAD MASONRY. Proceedings. 1994.E \& FN SPON. p.379-390.

YATES, A.; HAMPTON, D. Recent advances in the assessment of the environmental impact of buildings in the UK. In: Second International Conference Buildings and The Environment. Proceedings. Paris, 1997. p.59-66.

WAENY, J.C. Controle total da qualidade em metrologia. São Paulo. McGrawHill Ltda. 1992. 150p.

WAHLSTRÖM, et al. Environmental quality assurance for use of crushed mineral demolition wastes in earth constructions. Waste management. v.16, n.1-3, p.35$50,1996$. 
WAINWRIGHT, P.J. et al. Modifying the performance of concrete made with coarse and fine recycled concrete aggregates. in : INTERNATIONAL RILEM SYMPOSIUM ON DEMOLITION AND REUSE OF CONCRETE NAD MASONRY. Proceedings. 1994.E \& FN SPON. P.319-330.

WILBURN, D.R.; GOONAN, T.G. Economic assessments for construction applications - a materials flow analysis. U.S. Geological Survey Circular 1176. 1998. 37p. http : // greenwood.cr.usgs.gov/ pub/ circulars/ c1176/ c1176.html.

WILSON, O.D. et al. Waste management in the construction industry. In: CIB BUILDING CONGRESS - MATERIALS AND TECHNOLOGIES FOR SuStaInABle CONSTRUCTION. Suíça, 1998. Proceedings. Suíça, 1998. p.879-86.

WOOLEY, G. R. State of the art report use of waste materials in construction technological development. In: ENVIRONMENTAL ASPECTS OF CONSTRUCTION WITH WASTE MATERIALS. Great Britain, 1994. Proceedings. Great Britain, 1994. p.963-77.

ZORDAN, S.E. A utilização do entulho como agregado, na confecção do concreto. Campinas. 1997. 140p. Dissertação (Mestrado) - Faculdade de Engenharia Civil, UNICAMP.

ZORDAN, S.E et al. Concreto confeccionado com entulho reciclado :avaliação do desempenho em função do consumo de cimento. In: International high performance concrete, 2. Gramado, 1999. Anais. Gramado (RS), 1999.

ZWAN, J.T. Application of waste materials - a success now, a success in the future. In: WASTE MATERIALS IN CONSTRUCTIONS: PUTTING THEORY INTO PRACTICE. Great Britain, 1997. Proceedings. Great Britain, 1997. p.869-81. 